

\section{ANA LAURA ASSUMPÇÃO}

\section{Guignard: experiência em Ouro Preto por meio da representação pictórica}

Dissertação apresentada ao Programa de Pós-Graduação em Arquitetura e Urbanismo do Instituto de Arquitetura e Urbanismo da Universidade de São Paulo (IAU-USP) para a obtenção do título de mestre em Arquitetura e Urbanismo

Área de concentração: Teoria e História da Arquitetura e do Urbanismo

Orientador: Prof. Dr. Joubert José Lancha

Versão Corrigida

São Carlos

2019 
Autorizo a reprodução total ou parcial deste trabalho, por qualquer meio convencional ou eletrônico, para fins de estudo e pesquisa, desde que citada a fonte.

Email: alauraassumpcao@gmail.com

Ficha catalográfica elaborada pela Biblioteca do Instituto de Arquitetura e Urbanismo com os dados fornecidos pelo(a) autor(a)

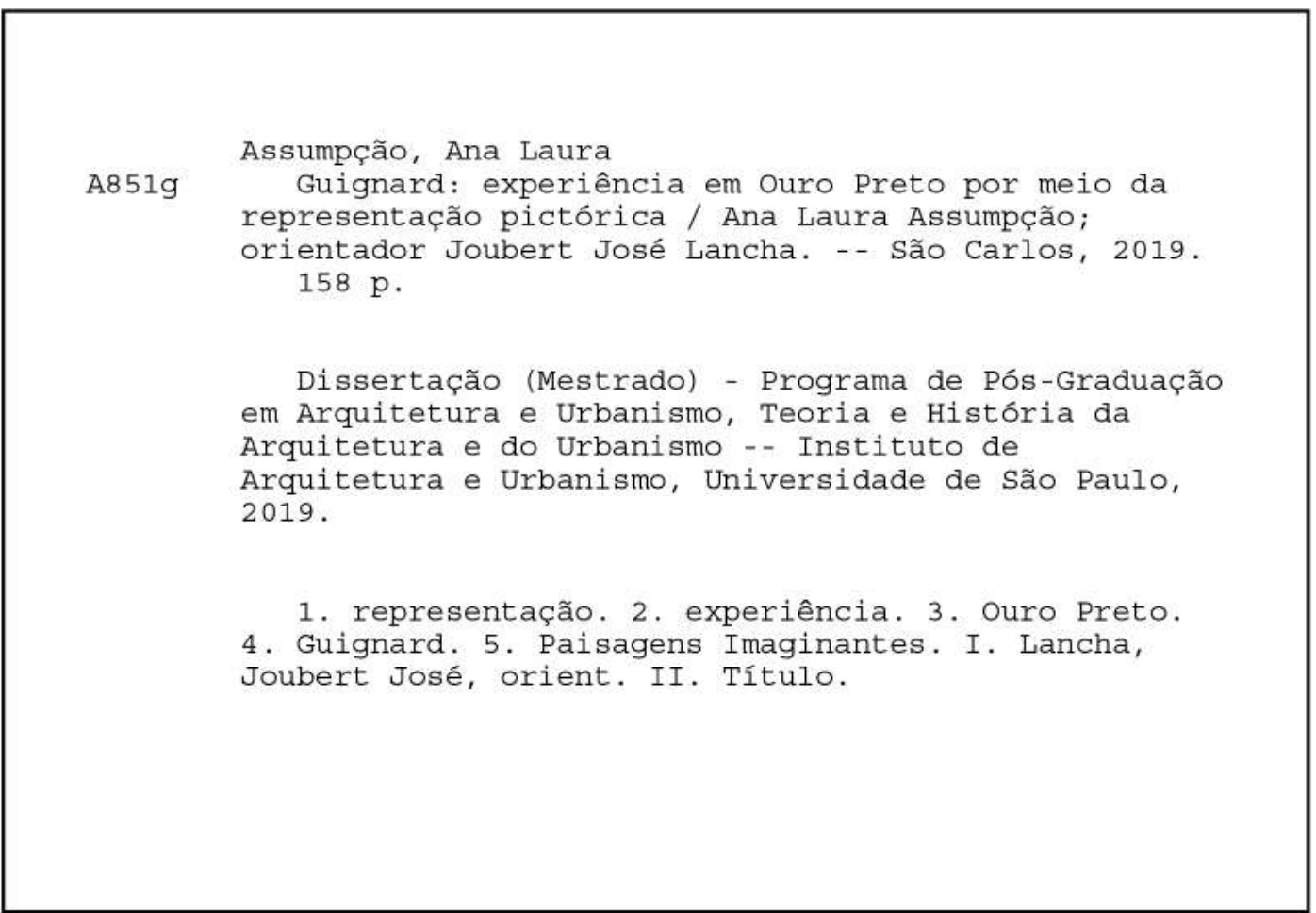




\section{FOLHA DE JULGAMENTO}

\section{Candidato(a): Ana Laura Assumpção}

Título da dissertação: "Guignard: experiência em Ouro Preto por meio da representação pictórica".

Data da defesa: 29/01/2019

Orientador: Prof. Dr. Joubert Jose Lancha

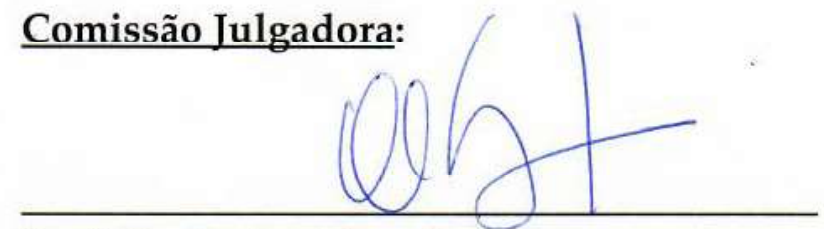

Prof. Dr. Joubert Jose Lancha

(IAU/USP)

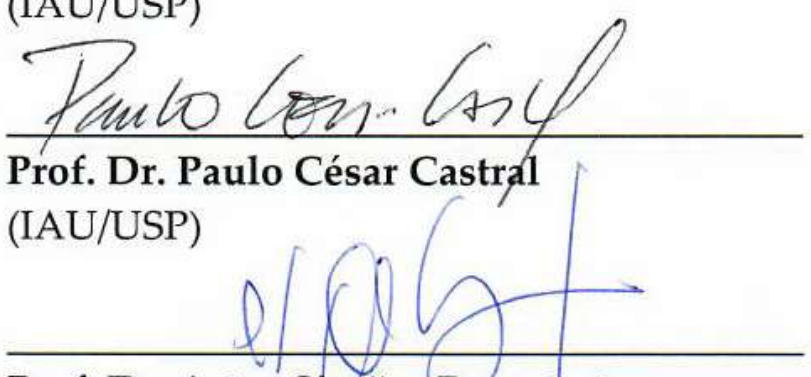

Prof. Dr. Artur Simões Rozestraten (FAU/USP)

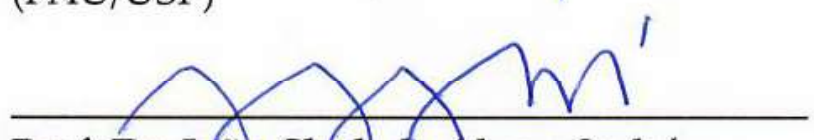

Prof. Dr. João Clark de Abreu Sodré

(USTT)

FAAP

\section{$\underline{\text { Resultado: }}$}

Não votante
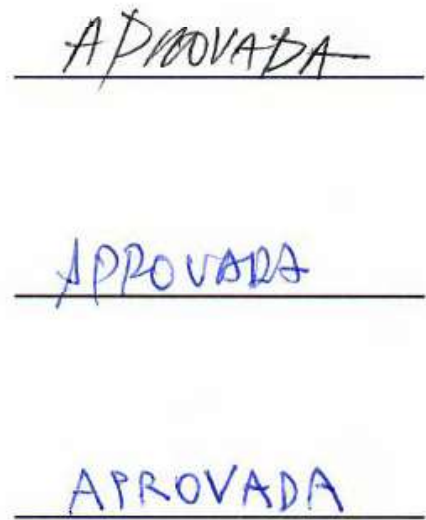

Coordenador e Presidente da Comissão de Pós-Graduação do Programa de PósGraduação em Arquitetura e Urbanismo: Prof. Dr. Tomás Antonio Moreira. 
Aos meus pais, por todo esforço que fizeram para eu chegar até aqui... 


\section{agradecimentos}

À CAPES, pelo auxílio financeiro.

Ao Castral, pela dedicação e pelo conhecimento passado durante tantos anos.

Ao Joubert, pela generosidade no período do mestrado.

À Simone, pela atenção e prontidão em ajudar no que necessário.

Ao professor convidado para a banca de qualificação, Artur Rozestraten, pelas sugestões e questionamentos produtivos.

Aos funcionários do IAU, pela assistência essencial aos pós-graduandos.

Ao grupo de pesquisa N.ELAC, pelo suporte e pela convivência saudável.

Às amigas da graduação, Natália, Eleonora, Marina, Jaqueline, Caroline e Gabriela, pela amizade e pelos momentos maravilhosos que já passamos juntas. Sobretudo à Gabriela, minha companheira de mestrado, de grupo de pesquisa e de linha de pesquisa, pela troca de conhecimento.

À família Vôlei CAASO, pelas horas descontraídas e alegres dentro e fora da quadra.

À minha família, em especial, meus pais, Marco e Ana Maria, e minhas irmãs, Ana Beatriz e Ana Júlia, pelo apoio e amor sem fim.

E ao Fernando, que escolheu me acompanhar na vida, pelo incentivo e carinho todos os dias. 
ASSUMPÇÃO, Ana Laura. Guignard: experiência em Ouro Preto por meio da representação pictórica. 2019. 158p. Dissertação (Mestrado em Arquitetura e Urbanismo) - Instituto de Arquitetura e Urbanismo, Universidade de São Paulo, São Carlos, 2019.

A presente dissertação discute dois períodos da história da arte brasileira, nos quais se busca analisar processos de representação pictórica, historicamente localizados, da ideia de brasilidade a partir do entendimento de construção da imagem por Merleau-Ponty (1908-1961), a saber: os registros dos artistas-viajante e a pesquisa plástica empenhada pelo modernismo. O processo de construção de uma imagem é baseado nas dimensões do processo perceptivo e cada artista desenvolve categorias históricas orientado conforme sua perspectiva vivida. Nesse sentido, a abordagem merleau-pontyniana problematiza a relação dialógica entre obra/representação, contexto histórico/cultural e sujeito/artista. O olhar atento ao papel desse processo na construção da representação, na construção da definição de um objeto, no caso a experiência de um lugar, é o foco desta pesquisa. Como consequência do entendimento merleaupontyniano, um dos períodos destacados aparece como um contraexemplo e o outro, como exemplo - e principal objeto de estudo -, cujo processo sugere, no recorte dessa investigação, uma experiência em Ouro Preto. O contraexemplo diz respeito ao contexto das viagens de artistas estrangeiros ao Brasil, especificamente, no panorama constituído pelos artistas-viajantes do século XIX e relacionado à noção de pitoresco. Foi escolhido para essa abordagem o percurso de Johann Moritz Rugendas (1802-1858). Já o objeto de pesquisa localiza-se um século depois, com base no processo da modernização. Toda a mudança de mentalidade e de estrutura da sociedade acabou refletindo na maneira de enxergar o mundo e, consequentemente, de representar o mundo. Como representativo, aparece o percurso do artista Alberto da Veiga Guignard (1896-1962), principalmente as "Paisagens Imaginantes", com as quais tornou visível sua aproximação com Ouro Preto. O sujeito da pesquisa, Guignard, localizado historicamente na cidade de Ouro Preto, possui processo particular de construção do olhar. São os processos de representação que caracterizam percursos distintos na construção da relação entre o sujeito e o mundo, no caso, a relação desse artista com o mundo em que viveu, com Ouro Preto e como essa relação se mostra em suas obras e nos possibilita partir da hipótese de pensá-la como experiência em Ouro Preto.

Palavras-chave: Guignard. Ouro Preto. representação. "Paisagens Imaginantes". 
ASSUMPÇÃO, Ana Laura. Guignard: experience in Ouro Preto through pictorial representation. 2019. 158p. Dissertação (Mestrado em Arquitetura e Urbanismo) - Instituto de Arquitetura e Urbanismo, Universidade de São Paulo, São Carlos, 2019.

The present dissertation discusses two periods of Brazilian art history, in which we seek to analyze processes of pictorial representation, historically located, of the idea of "brasilidade" from the understanding of image construction by Merleau-Ponty (1908-1961), namely: the records of traveling artists and the plastic research done by modernism. The process of construction of an image is based on dimensions of perceptive process and each artist develops historical categories oriented as their perspective lived. In this way, the approach "merleau-pontyniana" discusses the dialogical relation between work/representation, historical context/cultural context and subject/artist. The precise view on the role of this process in the representation construction, in the definition of an object construction, in this case the experience of a site, is the focus of this research. As a consequence of the understanding "merleau-pontyniano", one of the highlighted periods appears as a counterexample and the other, as example - and main study object -, whose process suggests, on this investigation clipping, an experience in Ouro Preto. The counterexample pertains to the context of traveling of foreign artists to Brazil, specifically, in the panorama constituted by traveling artists of the 19th century and related to the concept of picturesque. The trajectory of Johann Moritz Rugendas (1802-1858) was selected for this approach. In relation to the research object, it is located one century later, with basis in the modernization process. All changes of mentality and society structure ended up reflecting on the manner of seeing the world and, consequently, of representing the world. As representative, the trajectory of the artist Alberto da Veiga Guignard (1896-1962) appears, mainly the "Paisagens Imaginantes", with which his approximation with Ouro Preto became visible. The research subject, Guignard, historically located in the city of Ouro Preto, has particular process of view construction. It is the processes of representation which characterize different trajectories in the construction of relation between the subject and the world, in this case, the relation of this artist with the world where he lived, with Ouro Preto and how this relation appears in his works and enables us to use the hypothesis to consider it as experience in Ouro Preto.

Key words: Guignard. Ouro Preto. representation. "Paisagens Imaginantes". 


\section{lista de ilustrações}

Figura 1: Estudo de uma palmeira, 1822 a 1825 e Playa Rodriguez, 1835. Fonte: DIENER; COSTA, 1998 e DIENER; COSTA, 2002. [63]

Figura 2: Estudos de araucárias, 1824 e Serra Ouro-Branco, 1835. Fonte: DIENER; COSTA, 1998 e DIENER; COSTA, 2002. [63]

Figura 3: Vista da fazenda Mandioca, 1822 a 1825 e Mandiocca, 1835. Fonte: DIENER; COSTA, 2002. [63]

Figura 4: Vista da baía de Guanabara, RJ, 1822 e Vue de Rio de Janeiro, 1835. Fonte: DIENER; COSTA, 2002. [64]

Figura 5: Configuração dos primeiros arraias em Ouro Preto. Fonte: Croqui elaborado pela autora com base em VASCONCELLOS, 1977, p. 72. [71]

Figura 6: Crescimento centrípeto de Ouro Preto. Fonte:Croqui elaborado pela autora com base em VASCONCELLOS, 1977, p. 78. [71]

Figura 7: Crescimento centrífugo de Ouro Preto. Fonte: Croqui elaborado pela autora com base em VASCONCELLOS, 1977, p. 80. [71]

Figura 8: Vias principais e eixos de expansão de Ouro Preto. Fonte: Croqui elaborado pela autora com base em SALGADO, 2010, p. 88. [75]

Figura 9: Setores de ocupação da cidade de Ouro Preto. Fonte: Croqui elaborado pela autora com base em SALGADO, 2010, p. 115. [81]

Figura 10: Vista de Ouro Preto atualmente. Fonte: Fotografia feita pela autora, 2017. [82]

Figura 11: Vista de Ouro Preto na primeira metade do século XX. Fonte: Acervo Fotógrafo Luiz Fontana, Instituto de Filosofia, Artes e Cultura (IFAC). [83]

Figura 12: Vista de Ouro Preto atualmente. Fonte: Fotografia feita pela autora, 2017. [83]

Figura 13: Guignard em Ouro Preto, 1962, fotografia de Luiz Alfredo. Fonte: Acervo Museu Casa Guignard. [96]

Figura 14: Guignard em Ouro Preto, 1962, fotografia de Luiz Alfredo. Fonte: Acervo Museu Casa Guignard. [99]

Figura 15: Paisagem de Ouro Preto, período entre 1923 a 1950. Fonte: Acervo fotográfico Luiz Fontana, Instituto de Filosofia, Artes e Cultura (IFAC); Paisagem de Ouro Preto, 1958.Fonte: Alberto da Veiga Guignard, 1896-1962, 2005 e Fotografia feita pela autora, 2017. [104]

Figura 16: Ponte Seca de Ouro Preto, 1946. Fonte: MUSEU LASAR SEGALL, 1992; Ponte Seca de Ouro Preto, 1949. Fonte: MUSEU LASAR SEGALL, 1992 e Fotografia feita pela autora, 2017. [104]

Figura 17: Ouro Preto, 1960. Fonte: MORAIS, 1974 e Fotografia feita pela autora, 2017. [104]

Figura 18: Ouro Preto, 1961. Fonte: MUSEU LASAR SEGALL, 1992 e Fotografia feita pela autora, 2017. [104]

Figura 19: Desenho da varanda do Grande Hotel. Fonte: Fotografia da autora, 2017 e Fotografia feita pela autora, 2017. [104]

Figura 20: Sem título, 1953. Fonte: Disponível em: http://www.pinturasemtela.com. br/alberto-da-veiga-guignard-e-sua-passagem-pela-arte-moderna/. Acesso em: 25 de julho de 2017. [106]

Figura 21: Fotografia feita pela autora, 2017. [106]

Figura 22: Villa Ricca, 1835. Fonte: DIENER; COSTA, 2002. [111]

Figura 23: Três planos. Paisagem Imaginante, 1943, 41 x 33cm. Fonte: FROTA, 1997. [113] 
Figura 24: Três planos. Paisagem Imaginante, 1939, 55 x 80cm. Fonte: FROTA, 1997. [113]

Figura 25: Três planos. Paisagem Imaginante, 1942, 80 x 60cm. Fonte: FROTA, 1997. [113]

Figura 26: Segundo plano em destaque. Paisagens Imaginantes, 1941, $150 \mathrm{x}$ $100 \mathrm{~cm}$. Fonte: FROTA, 1997. [114]

Figura 27: Primeiro plano em destaque. Paisagens Imaginantes, 1941, $150 \mathrm{x}$ $100 \mathrm{~cm}$. Fonte: FROTA, 1997. [114]

Figura 28: Paisagem sem o primeiro plano. Paisagem Imaginante, 1939, $55 \mathrm{x}$ $80 \mathrm{~cm}$.Fonte: FROTA, 1997. [115]

Figura 29: Paisagem sem o primeiro plano. Paisagem Imaginante, 1943, $41 \times 33 \mathrm{~cm}$ e Paisagem Imaginante, 1942, 80 x 60cm. Fonte: FROTA, 1997. [116]

Figura 30: As gemeas Lea e Maura, 1940, $110 \times 130 \mathrm{~cm}$. Fonte: FROTA, 1997. [116]

Figura 31: Paisagem Imaginante, 1950, $80 \times 110 \mathrm{~cm}$. Fonte: FROTA, 1997. [118]

Figura 32: Edificações em destaque. Noite de São João, 1942, $80 \times 60 \mathrm{~cm}$; Paisagem, 1947, 158 x 208cm e São João, 1959, 38.5 x 29cm. Fonte: FROTA, 1997. [119]

Figura 33: Elementos em destaque. São João, 1961, $61 \times 46 \mathrm{~cm}$. Fonte: Alberto da Veiga Guignard, 1896-1962, 2005; Paisagem Imaginante, 1955, 95 x 78cm. Fonte: FROTA, 1997 e Balõezinhos, sem data, $29,5 \times 47 \mathrm{~cm}$. Fonte: Um mundo a perder de vista: Guignard, 2008. [119]

Figura 34: Leitura de forma adquirida pela união das igrejas feita pela autora. Paisagem Imaginante, $1950,80 \times 110 \mathrm{~cm}$. Fonte: FROTA, 1997; Paisagem Imaginante, 1961, 50 x 43cm. Fonte: FROTA, 1997; São João, 1961, 55 x 46cm. Fonte: Alberto da Veiga Guignard, 1896-1962, 2005. [120]

Figura 35: Leitura de simetria feita pela autora. Exemplos do primeiro, segundo e terceiro caso, respectivamente. [121]

Figura 36: Paisagens sem elementos. Paisagem Imaginante, 1950, 80 x $110 \mathrm{~cm}$ e Paisagem Imaginante, 1955, 95 x 78cm. Fonte: FROTA, 1997. [122]

Figura 37: Retrato de Sara Ávila, 1954, 50 x 41cm. Fonte: FROTA, 1997. [124]

Figura 38: Marília de Dirceu, 1957, 61,5 x 51,5 cm. Fonte: FROTA, 1997. [125]

Figura 39: Retrato de Priscila Freire, 1959, $55 \times 46 \mathrm{~cm}$. Fonte: FROTA, 1997. [126]

Figura 40: Retrato de Lúcia, 1960, 48,2 x 35,5cm. Fonte: FROTA, 1997. [127]

Figura 41: Autorretrato, 1961, $64,5 \times 50 \mathrm{~cm}$; Retrato, 1961, $50 \times 40 \mathrm{~cm}$ e Retrato de Wilson Frade, $1961,79 \times 58,5 \mathrm{~cm}$. Fonte: FROTA, 1997. [127]

Figura 42: Espacialidade das igrejas nas paisagens da segunda fase. [128]

Figura 43: Espacialidade das igrejas nas paisagens da terceira fase. Paisagem Imaginante, 1961, 61 x 46cm. Fonte: FROTA, 1997; Paisagem Imaginante, 1961, 55 x 46cm. Fonte: FROTA, 1997 e Sem título [festa junina], 1961, 50 x 40cm. Fonte: MUSEU LASAR SEGALL, 1992. [128]

Figura 44: Paisagem Imaginante, 1961, 55 x 46cm. Fonte: FROTA, 1997. [129]

Figura 45: Paisagem Imaginante, 1961, 61 x 46cm. Fonte: FROTA, 1997. [129]

Figura 46: Vegetação nas paisagens. Paisagem Imaginante, 1961, $61 \times 46 \mathrm{~cm}$. Fonte: FROTA, 1997; Sem título [festa junina], 1961, 50 x 40cm. Fonte: MUSEU LASAR SEGALL, 1992 e Paisagem Imaginante, 1961, 55 x 46cm. Fonte: FROTA, 1997. [131]

Figura 47: Paisagem Imaginante, 1961, 61 x 46cm. Fonte: FROTA, 1997. [131]

Figura 48: Balões nas paisagens. Paisagem Imaginante, 1961, $61 \times 46 \mathrm{~cm}$. Fonte: FROTA, 1997 e Sem título [festa junina], 1961,50 x 40cm. Fonte: MUSEU LASAR SEGALL, 1992. [132]

XIV Figura 49: Leitura de simetria feita pela autora. Paisagem Imaginante, 1961, $55 \mathrm{x}$ 
46cm; Paisagem Imaginante, 1961, 61 x 46cm e Paisagem Imaginante, 1961, $55 \mathrm{x}$ $46 \mathrm{~cm}$. Fonte: FROTA, 1997. [133]

Figura 50: Paisagens sem elementos - segunda fase.Paisagem Imaginária, 1952, $160 \times$ 70,5cm. Fonte: FROTA, 1997 e Paisagem de Minas, década de 1940, 32 x $40 \mathrm{~cm}$. Fonte: Alberto da Veiga Guignard, 1896-1962, 2005. [133]

Figura 51: Paisagens sem elementos - terceira fase.Paisagem Imaginante, 1961, 55 x 46cm; Paisagem Imaginante, 1961, 61 x 46cm. Fonte: FROTA, 1997. [133]

Figura 52: Passagem da primeira para segunda fase. [140]

Figura 53: Passagem da segunda para terceira fase. [140]

Figura 54: Paisagem de Ouro Preto, período entre 1923 a 1950. Fonte: Acervo fotográfico Luiz Fontana, Instituto de Filosofia, Artes e Cultura (IFAC). [141]

Figura 55: Paisagem de Ouro Preto, período entre 1923 a 1950. Fonte: Acervo fotográfico Luiz Fontana, Instituto de Filosofia, Artes e Cultura (IFAC). [141]

Figura 56: Paisagem de Ouro Preto, período entre 1923 a 1950. Fonte: Acervo fotográfico Luiz Fontana, Instituto de Filosofia, Artes e Cultura (IFAC). [142]

Figura 57: Paisagem de Ouro Preto, período entre 1923 a 1950. Fonte: Acervo fotográfico Luiz Fontana, Instituto de Filosofia, Artes e Cultura (IFAC). [142]

\section{lista de quadros}

Quadro 1: Linha do tempo da história da arte brasileira elaborada pela autora, 2017. [22 e 23]

Quadro 2: Linha do tempo elaborada pela autora, 2017. [60]

Quadro 3: Linha do tempo elaborada pela autora, 2017. [95]

Quadro 4: Quadro da leitura de simetria das obras de Guignard da segunda e terceira fase elaborado pela autora, 2017. [123] 
Capítulo I

Mundo percebido 31

Corpo e visão $\quad 33$

$\begin{array}{ll}\text { Pintura } & 37\end{array}$

Pintura e linguagem $\quad 39$

Pintura de Cézanne $\quad 41$

Estilo na pintura $\quad 44$

Capítulo II $\quad 47$

Paisagem $\quad 49$

Pitoresco $\quad 51$

A prática de viagem $\quad 53$

Prática de viagem na América $\quad 54$

Rugendas $\quad 56$

Um olhar sobre Rugendas $\quad 61$

Capítulo III $\quad 67$

Sucesso e decadência [fase 1] 69

Estagnação [fase 2] $\quad 73$

Decadência e expansão [fase 3] $\quad 76$

Ouro Preto turística $\quad 84$

$\begin{array}{lr}\text { PARTE II } & 87\end{array}$

Capítulo I $\quad 89$

$\begin{array}{ll}\text { Guignard pessoa } & 91\end{array}$

Guignard professor $\quad 94$

Guignard artista $\quad 99$

Primeiro olhar sobre as paisagens de Guignard 103

$\begin{array}{ll}\text { Capítulo II } & 109\end{array}$

Representação 111

$\begin{array}{ll}\text { Experiência } & 117\end{array}$

$\begin{array}{ll}\text { Imaginação } & 128\end{array}$

$\begin{array}{ll}\text { Considerações finais } & 137\end{array}$

$\begin{array}{ll}\text { Referências } & 143\end{array}$

$\begin{array}{ll}\text { Apêndices } & 151\end{array}$

$\begin{array}{ll}\text { Anexos } & 153\end{array}$ 
introdução 
Sistema simbólico dentro de um universo cultural, a obra de arte ultrapassa sua forma materializada para, através do tema escolhido pelo artista, expressar suas estruturas mentais e o contexto histórico de uma época, que são seu conteúdo ou significado intrínseco. (MULLER, 1983, p. 22) 
As imagens, de maneira geral, têm grande importância na sociedade em que vivemos e estão se expandindo cada vez mais, devido aos avanços tecnológicos. Isso ocorre porque o sentido da visão é predominante no nosso campo perceptivo. Mas, essa noção não é recente, foi com a modernidade que se elevou o sentido da visão em detrimento dos demais, com o desenvolvimento dos meios tipográficos e das imagens fotográficas, o que se difere bastante da Idade Média, por exemplo, onde se tinha uma cultura oral sustentada pela memória em que os sentidos da audição e olfato se sobressaiam. (ANDRIOLO, 2011, p. 80)

É esse campo perceptivo constituído pela visão que merece destaque aqui. Objetiva-se discutir, na presente dissertação, a importância das imagens como consequência de uma cultura e como papel fundamental na construção da ideia de um objeto, no caso, da experiência de um lugar.

O processo de construção de uma imagem - considerando a pintura a representação mais relevante para a presente pesquisa - é baseado nas dimensões do processo perceptivo. A abordagem merleau-pontyniana problematiza a relação dialógica entre obra/representação, contexto histórico/cultural e sujeito/artista. "As imagens não são reproduções de um mundo objetivo; outrossim, apresentam um traço da relação do sujeito com o mundo percebido". (ANDRIOLO, 2011, p. 78)

Cada artista desenvolve categorias históricas orientado conforme sua perspectiva vivida, acrescentando e mudando temas e pontos de vista, mas sempre trabalhando dentro de uma estrutura social e psicológica do processo perceptivo. (ANDRIOLO, 2011, p. 77). Isso afirma a particularidade da representação, seja ela desenho, pintura, escultura. A relação artista e mundo é única e é revelada na representação, tal relação ocorre do interior para o exterior e vice-versa. Como define Juhani Pallasmaa (2013, p. 93), a respeito da representação do desenho:

um desenho olha simultaneamente para fora e para dentro, para o mundo observado ou imaginado e para a própria personalidade e o mundo mental do desenhista. Cada esboço e desenho contém parte do artista e de seu mundo mental, ao mesmo tempo em que representa um objeto ou uma vista do mundo real ou um universo imaginado.

Essa relação do sujeito com o que observa, ou seja, com o mundo percebido, se constitui na própria construção do olhar, pois o olhar ensina a pensar e, sendo ele o sentido predominante no campo perceptivo, como já visto, proporciona sensações complexas por meio da percepção. Como diz Marilena Chauí (1988, p. 40):

Se o olhar usurpa os demais sentidos fazendo-se cânone de todas as percepções é por que, como dizia Merleau-Ponty, ver é ter à distância. O olhar apalpa as coisas, repousa sobre elas, viaja no meio delas, mas delas não se apropria. "Resume" e ultrapassa os outros sentidos porque os realiza naquilo que Ihes é vedado pela finitude do corpo, a saída de si, sem precisar de mediação alguma, e a volta a si, sem sofrer qualquer alteração material.

No Brasil, o contato com diversas representações produzidas, seja por artistas estrangeiros, seja por nacionais, cria uma oportunidade de investigar sobre a contribuição que deixaram para o país, reconhecendo 
que registraram partes essenciais de uma história que nos diz respeito. Além disso, o legado iconográfico possibilita novas aproximações com a nossa história e forja uma memória do passado, mesmo lembrando que há a condição de nos vermos pelos olhos dos outros. Segundo Ana Maria Belluzzo (1999, v. 1, p. 13), deve-se levar em conta que as obras carregam uma "história de pontos de vista, de distâncias entre modos de observação e de triangulações do olhar".

Dentro de um panorama da história da arte brasileira, pode-se recortar dois períodos em que a ideia de construção de uma imagem dotada de brasilidade se fez bastante presente, a saber: os registros dos artistasviajantes e a pesquisa plástica empenhada pelo modernismo.

Um ponto inicial dos "retratos da nação", no entanto, vem com o descobrimento do Brasil por Pedro Alvares Cabral e a consequente leitura do desconhecido feita por Pero Vaz de Caminha, na "Carta" encaminhada para o rei de Portugal, "hoje considerada oficialmente uma espécie de certidão de nascimento do Brasil: documento fundador e marco da origem da nossa história". (SCHWARCZ; STARLING, 2015, p. 28). Nesse caso não difundida por meio de imagem, no sentido de uma representação pictórica, mas por imagem em forma de texto.

O primeiro período, dos artistas-viajantes, foi marcadamente formado pelo olhar europeu sobre a nova terra. Um olhar de fora que, em si, já vem carregado de determinadas questões artísticas, sociais e culturais. Podese dizer que o processo de construção de uma imagem do país teve sua origem aqui, nas viagens dos artistas-viajantes europeus que produziam diversos tipos de registros pictóricos da terra desconhecida a procura de
[Quadro 1] Linha do tempo da história da arte brasileira elaboradapelaautora, 2017.

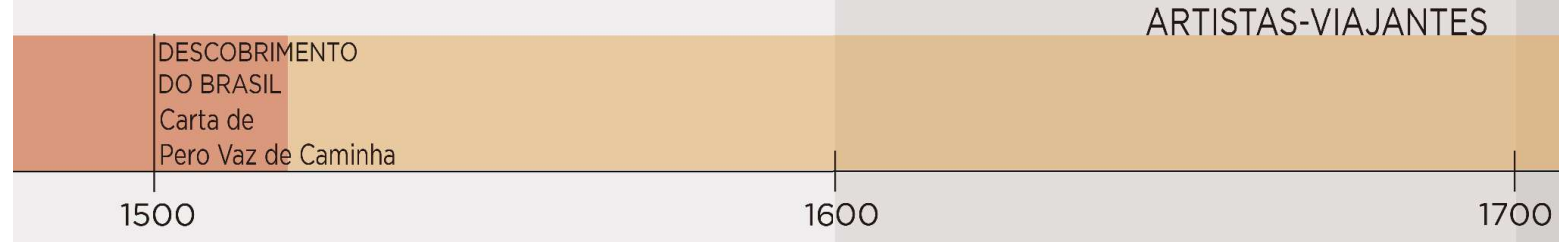

Expansão Urb Auge da miner

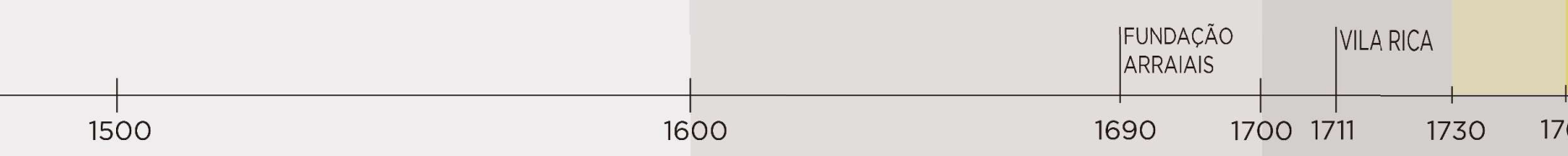

PERIODO COLONIAL

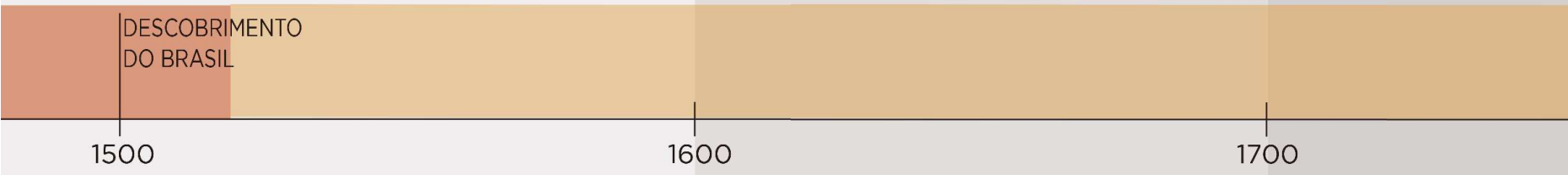


década de 1820, nota-se uma prática determinada no campo da visualidade, alinhada com a 'norma culta' das grandes academias europeias de arte. (CHIARELLI, 2010, p. 130)

Leis e normas passaram a vigorar no ensino artístico brasileiro. Cada vez mais foi sendo afastada a arte que se tinha no período colonial e sendo instaurado os princípios neoclássicos que, por muito tempo, foram as bases da arte brasileira.

Tal situação foi interrompida pela modernidade, com a eclosão da Semana de 1922 do modernismo. Aqui se inicia o último dos períodos pontuados. A ideia de modernismo não advinha de um rompimento, mas sim de uma conciliação entre tradição e modernidade.

Naquele momento, não se tratava de escolher entre a tradição e a modernidade, mas sim, de dispor das duas, naquilo que elas poderiam ser úteis a um projeto cultural maior: a construção de uma jovem nação e sua identidade nacional. (PEREIRA, 2012, p. 102)

Tradição esta que o modernismo teria resgatado da arte produzida na colônia. "Ao mesmo tempo em que atualizava o pensamento artístico nacional, colocando-o a par do que ocorria, sobretudo na Europa, ele teria 'reabrasileirado' a arte levada a cabo". (CHIARELLI, 2010, p. 126). Sendo entendido como conciliação e não como ruptura, nota-se a importância do século XIX para a modernidade do século XX.

A modernização do país e a busca por uma identidade nacional consolidam uma outra imagem o Brasil, agora baseada em um olhar de dentro, propriamente sobre o seu país. Além disso, este pode ser o primeiro momento em que se busca a construção de uma raiz "autêntica" do Brasil.

Assim sendo, como consequência do entendimento merleau-pontyniano, o primeiro período aparecerá, na presente pesquisa, como contraexemplo e o segundo, como exemplo - e principal objeto de estudo -, cujo processo sugere, no recorte dessa investigação, uma experiência em Ouro Preto.

O contraexemplo, diz respeito ao contexto da consolidação da noção de paisagem e do consequente modelo de apreciação europeu, o pitoresco; das práticas de viagem e das viagens de artistas estrangeiros ao Brasil, especificamente, no panorama constituído pelos artistas-viajantes do século XIX. Foi escolhido para essa abordagem o percurso de Johann Moritz Rugendas (1802-1858). Já o objeto de pesquisa, localiza-se um século depois, com base no processo da modernização. Toda a mudança de mentalidade e de estrutura da sociedade acabou refletindo na maneira de enxergar o mundo e, consequentemente, de representar o mundo. Como representativo, entra o percurso do artista Alberto da Veiga Guignard (1896-1962), principalmente as obras "Paisagens Imaginantes", com as quais tornou visível sua aproximação com Ouro Preto. Cabe aqui, brevemente, destacar a escolha de Ouro Preto como contexto físico da pesquisa: bastante representativa do Brasil, desde a sua fundação até os dias atuais, foi uma cidade que desenvolveu a fisionomia do país e que se transformou no símbolo da identidade nacional.

A conjuntura moderna, de esforço em encontrar essa identidade brasileira, repensa noções antes pregadas pelo clássico. Longe das amarras europeias, retoma-se a importância da formação e da cultura propriamente desenvolvidas no país. A noção de paisagem, por exemplo, antes fundamentada numa relação entre um modelo a ser seguido e a 
representação da natureza, passa a ser vista sob a noção da própria arte moderna, através de parâmetros não tão rígidos, inclusive como colocada por Maurice Merleau-Ponty (1908-1961).

A paisagem, nesse sentido, vem carregada de um conteúdo singular do sujeito, assim como reforça Merleau-Ponty (2004) nas pontuações sobre a pintura moderna. Por meio da percepção, o sujeito reconhece elementos e os associa com algo já conhecido, uma experiência que advém de uma memória, possibilitada pela consciência.

Esta paisagem constituída, em partes, por algo que advém da arte, também requer uma experiência sensível - esta, por sua vez, relacionada a um contexto cultural e histórico -, possibilita uma percepção e um contato do sujeito com o mundo. Ao mesmo tempo que o sujeito observa o mundo a sua volta, esse mundo se mostra para ele. Do mesmo modo que a paisagem não é algo já dado, não é natureza ou um pedaço de terra delimitado, mas sim uma construção histórica e cultural; a pintura ou, mais amplamente, a representação, também. Ambas se constituem na relação sujeito/objeto, sujeito/lugar, sujeito/mundo.

Sendo a paisagem uma construção histórica e cultural e constituída no ato perceptivo, no ato de interação entre o sujeito e o mundo, o enfoque aqui se volta para esse "mundo", no caso, a cidade de Ouro Preto. A presente pesquisa se baseia em compreender tal cidade mineira sob o viés da noção de paisagem, entendendo-a menos como território físico e mais como imagem.

O entendimento da noção clássica de paisagem, do pitoresco e da consolidação na atuação do artista Rugendas é o percurso que embasará a compreensão dessa nova noção de paisagem, proposta aqui por Guignard em Ouro Preto. A construção da paisagem ouro-pretana contará com um embasamento quanto à contextualização histórica, a formação da cidade, a expansão dos seus limites urbanos e a morfologia peculiar, para depois partir para a análise das pinturas de paisagem de Guignard, numa tentativa de responder a hipótese da pesquisa de ser possível perceber a experiência do artista em Ouro Preto por meio de suas representações pictóricas. 

capítulo I

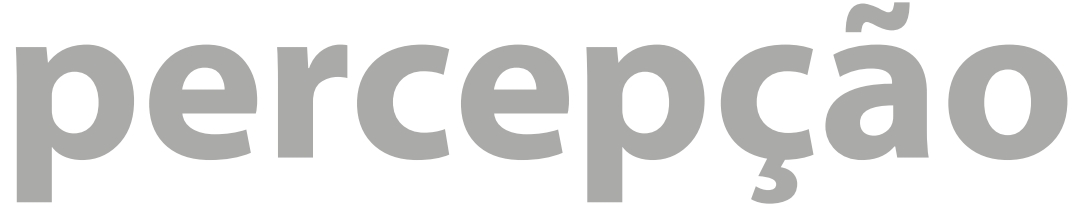


Nesse capítulo buscaremos compreender o pensamento de MerleauPonty voltado para arte moderna. Como sua reflexão, com base na pintura moderna e na expressão artística, responde uma série de questões sobre a relação existente entre a arte e o homem, partindo do mundo sensível no qual ela ocorre.

Para tal, foram analisados textos de Merleau-Ponty, especificamente, $O$ olho e o espírito, A linguagem indireta e as vozes do silêncio e A dúvida de Cézanne [1]; juntamente a eles, foi selecionado uma série de autores que se basearam na concepção merleau-pontyniana e estudaram mais profundamente não somente esses textos, mas de certa maneira, o tema a ser discutido aqui: uma reflexão sobre o pensamento do filósofo acerca de questões que envolvem a relação entre arte e o processo perceptivo.

O capítulo foi estruturado conforme as principais concepções desse filósofo e a sequência delas vêm para facilitar o entendimento sobre o que se propõe refletir, deixando claro que esta foi uma lógica criada pela autora, segundo interesse de sua pesquisa: por meio da discussão acerca das noções que corroboram para a constituição do conceito de percepção, caracterizar a experiência de Guignard em Ouro Preto por meio da análise de suas obras, tendo em vista o percurso pessoal e profissional desse artista.

[1] Abreviaturas das obras de Merleau-Ponty ao longo do capítulo: OE. O olho e o espírito LI. A linguagem indireta e as vozes do silêncio DC. A dúvida de Cézanne VI. O visível e o invisível PhP. Fenomenologia da percepção CNP. Le cinéma et la nouvelle psychologie PM. A prosa do mundo 
A ideia inicial é compreender que Merleau-Ponty busca restituir o contato primordial do sujeito com o mundo percebido, como sendo o caminho seguido pelo pensamento moderno. Esse contato com o mundo percebido é possibilitado pela arte, pois é ela quem engatilha a percepção e, como consequência, o processo que a envolve, ligado a experiência vivida. No entendimento de Merleau-Ponty (VI, apud ALVES, 2013, p. 22), a percepção é o próprio encontro com as coisas naturais, mas é também um recorte do mundo vivido.

Reestabelecer o contato primordial significa encontrar a essência do mundo, voltar as coisas mesmas, voltar ao mundo em seu estado nascente, como se tivéssemos o primeiro contato com aquilo que nos aparece, a coisa percebida. Mas como isso se configura? A relação do homem com o mundo ocorre de modo casual, no sentido de não considerar as significações inerentes ao mundo objetivo e se abrir para essa experiência originária, para o intenso sentir. Por outro lado, o mundo objetivo, que é o mundo humano, esse que conhecemos, está repleto de signos e significados dos quais, nós, sujeitos, não conseguimos nos desvencilhar facilmente e, como consequência, fragiliza-se o processo perceptivo.

O mundo primordial é o mundo pré-objetivo, como dito, aquele que é anterior ao conhecido, mais pontualmente, o mundo da percepção. O sujeito precisa ficar livre dos juízos e valores inerentes ao mundo conhecido para retornar à experiência originária, onde emergem os sentidos.

Para Merleau-Ponty, o ponto de origem do mundo primordial é o entendimento de tal relação existente entre o homem e o mundo, vista a partir de um foco mais específico que é correspondência entre eles, explicada por Alves (2013) com o termo indivisibilidade. Essa indivisibilidade entre o homem, ou ainda, o seu corpo e o mundo percebido, acontece pelo que o filósofo chama de "a vinda a si do visível", pela conexão estabelecida entre quem olha e quem é olhado. Eliane Escoubas (2005, p. 168) explica essa expressão:

\footnotetext{
"A vinda a si do visível" não é outra coisa senão a inseparabilidade do "vidente" e do "visto", o único acontecimento pelo qual ambos advêm. Ela não é outra coisa senão sua reciprocidade - e, portanto, sua reversibilidade: os pintores, diz Merleau-Ponty (OE), muitas vezes afirmaram que as coisas olhavam para eles.
}

Nesse ponto, pode-se ainda citar a noção de afetividade, também colocada pelo filósofo. A relação entre quem olha e quem é olhado, pode ser pensada como um corpo que afeta e é afetado. Entendendo o afeto dentro do campo fenomenológico, ele é "a busca de si no outro, num processo de interrogação e conhecimento" (RAMOS, 2017, p. 52), e mais, o afeto é conhecimento, vou me conhecendo nesse jogo de relações, é a tensão de uma existência em direção à outra num jogo de negação e aceitação, mas sem a qual, todavia, esta existência não se estrutura. (RAMOS, 2017, p. 55). Marcon e Furlan (2015, p. 228) definem o afeto como a tensão que surge entre o corpo próprio e seu mundo, na via de mão dupla onde o significado e o significante são dois momentos de uma mesma expressão.

Ao nos relacionarmos com o mundo por meio da percepção e, consequentemente, da experiência afetiva - já que é através delas que as coisas são reveladas ao nosso corpo -, passamos a explorar o mundo. 
"Sempre exploramos o mundo por meio do nosso corpo" (ALVES, 2013, p. 26). Isso se explica pela relação corpo/coisa que, para Merleau-Ponty, o sentido da coisa ao ser percebido pelo meu olhar, sai de si para se comunicar com o meu corpo.

Em contrapartida, aparece o mundo da ciência, o mundo visto pelo olhar científico, o qual é condicionado pelo modelo das máquinas humanas. Segundo Merleau-Ponty (OE, 2004, p. 13), "a ciência manipula as coisas e renuncia habitá-las". Se, inclusive, meu corpo é entendido como máquina, não posso senti-lo como sendo meu corpo, como tendo os meus gestos e meus atos. Esse pensamento é o que o filósofo chama de pensamento de sobrevoo. Uma noção de ter o mundo e as coisas à distância e não em contato direto com o sujeito.

Os que acreditam nesse pensamento da ciência, reduzem o mundo à uma dimensão de objeto ao verem-no como uma representação. Explicando melhor, segundo o filósofo (OE), é impossível estar no mundo sem se relacionar com ele: meu corpo está presente no mundo, meu corpo faz parte desse mundo. Sendo assim, é impossível se relacionar com esse distanciamento, o mundo não é algo passível de ser construído mentalmente e sem nenhum contato direto, como se fosse um objeto. Estamos enraizados no mundo.

Merleau-Ponty ainda afirma ser impossível abstrair a presença das sensações em qualquer hipótese, por mais que os cartesianos, - os que creem na ciência em detrimento da percepção -, pareçam não habitar o mesmo mundo que busca explicar suas ciências e seus cálculos matemáticos. Segundo Alves (2013, p. 12), conforme o pensamento de Merleau-Ponty,

\begin{abstract}
É indispensável considerar o mundo percebido e crer na indivisibilidade entre corpo e espírito. Para ele, enquanto a ciência permanece excluindo a percepção e evita considerar a presença do homem na natureza quando a estuda, a arte, em contraponto, nos coloca dentro do mundo percebido.
\end{abstract}

Cada vez mais a ciência moderna trabalha com técnicas mais avançadas, como se as coisas fizessem parte de um grande laboratório. Não há mais a esfera do contato, perde-se a relação imediata, ou somente, mais próxima do homem com as coisas. Em outras palavras, ao posicionar o pensamento a uma certa distância, quase que lhe dando um caráter divino, o homem da ciência acaba por afastar o sujeito do objeto, o homem do mundo percebido. Nesse sentido,

\footnotetext{
Manipulavam os resultados de suas pesquisas, pois o homem da ciência se enganava ao acreditar que poderia ausentar-se de seu corpo - suas experiências de vida, sua percepção, sua memória e seu contexto - para examinar friamente o objeto pelas faculdades da consciência. (ALVES, 2013, p. 17)
}

Pensando do ponto de vista da ciência, "a própria percepção deve ser explicada ou fazer parte desse mundo construído cientificamente". (FURLAN; ROZESTRATEN, 2005, p. 62). Mas como explicar algo que somente existe se conciliado à noção de proximidade e de relação com o mundo? Estamos presentes em um mundo e a vivência adquirida nele se dá corporalmente. Para Merleau-Ponty, o corpo e suas experiências no 
mundo são exteriores, mas também são partes integrantes do interior, com isso não é possível separar o sujeito do objeto. (ALVES, 2013, p. 12)

Como resposta a esse pensamento científico, Merleau-Ponty defende seus estudos acerca da fenomenologia, defendendo, assim, a experiência vivida e seu desdobramento na noção de corpo, percepção e expressão, como será abordado mais à frente. Segundo o filósofo, para penetrar no mundo da percepção, aquele que nos é revelado pelos sentidos, não é necessário nem instrumentos nem cálculos matemáticos, apenas precisamos nos deixar viver. Como complementa Lima Neto (2012, p. 28-29), "o mundo aqui não é o mundo objetivo da ciência, [...] é, ao contrário, o mundo do corpo sujeito de percepção, corpo enraizado no mundo da experiência sensível."

\section{Corpo e visão}

O contato primordial se relaciona, dentre diversos pontos, com a reflexão sobre o corpo. Para considerar a relação do homem moderno com o mundo não-objetivo, é preciso pensar que o homem habita o mundo por meio de uma relação perceptiva com as coisas que o circundam e que a "percepção se dá no e pelo corpo humano através de suas experiências, espacialidades e temporalidades. O corpo é um todo que inclui o espírito, presente como todo no mundo". (ALVES, 2013, p. 18). Mais ainda, o "pensamento e a percepção se fazem nas coisas. Mediante a percepção, podemos compreender a relação entre alma e corpo. O corpo é a sede da percepção". (LIMA NETO, 2012, p. 24)

Nesse sentido, o corpo faz parte do mundo visível. Ou seja, é a partir desse corpo, o qual é móvel, que me relaciono com o mundo. É a partir da visão, que abro esse corpo e também a alma, para o mundo, já que tanto o corpo quanto a alma são as formas do homem estar nesse mundo. "A visão faz a alma ficar contente na prisão do corpo". (MERLEAU-PONTY, OE, 2004, p. 42)

Da mesma maneira que meu corpo depende da visão, minha visão depende do movimento. O movimento é "a sequência natural e o amadurecimento da visão". (MERLEAU-PONTY, OE, 2004, p. 16). Ocorre que as coisas são movidas, mas meu corpo se move e, diante disso, é que vejo tudo o que está ao alcance do meu olhar e consigo me colocar perto dos lugares distantes quanto dos lugares próximos, tudo ao mesmo tempo.

É preciso tomar ao pé da letra o que nos ensina a visão: que por ela tocamos o sol, as estrelas, estamos ao mesmo tempo em toda parte, tão perto dos lugares distantes quanto das coisas próximas. (MERLEAU-PONTY, OE, 2004, p. 43)

Mais ainda, só é possível ser-no-mundo por meio do corpo e só percebemos o mundo em nós, pelo corpo. É justamente uma relação de troca, o corpo está situado no mundo e entre eles ocorre uma relação dialética entre quem toca e quem é tocado, entre quem vê e é visto, entre quem afeta e é afetado, isso se dá pela reversibilidade do corpo. É possível dizer que o corpo percebe as coisas pela operação perceptiva, mas também o corpo passa a ser coisa quando ele é o percebível. Mas aqui cabe ressaltar que esse processo não é definido, não se sabe o momento em que o corpo deixa de perceber para ser percebível, é um movimento natural da percepção.

A relação entre vidente e visível foi bastante discutida por Merleau-Ponty (OE) e é relevante pensar que para além do corpo que, ao mesmo tempo, 
olha as coisas e é olhado por elas, ele pode-se reconhecer naquilo que vê. Nesse sentido, o vidente não se apropria das coisas, ele apenas se aproxima delas pelo olhar.

Um corpo humano está aí quando, entre vidente e visível, entre tocante e tocado, entre um olho e o outro, entre a mão e a mão se produz uma espécie de recruzamento, quando se acende a faísca do senciente-sensível, quando se inflama o que não cessará de queimar, até que um acidente do corpo desfaça o que nenhum acidente teria bastado para fazer. (MERLEAU-PONTY, OE, 2004, p. 18)

Merleau-Ponty (OE) se utiliza da expressão "precessão recíproca" para descrever a interrelação existente entre "o que é" e "o que se vê e faz ver", para ele isso é o que define a visão. (CARBONE, 2013, p. 120). No entanto, essa relação ocorre a partir do momento que aprendemos a ver, como explica Merleau-Ponty (OE, 2004, p. 19),

Toda a questão é compreender que nossos olhos já são muito mais que receptores para as luzes, as cores e as linhas: computadores do mundo que têm o dom do visível, como se diz que o homem inspirado tem o dom das línguas. Claro que esse dom se conquista pelo exercício, e não é em alguns meses, não é tampouco na solidão que um pintor entra em posse de sua visão. A questão não é essa: precoce ou tardia, espontânea ou formada no museu, sua visão em todo caso só aprende vendo, só aprende por si mesma.

Segundo Merleau-Ponty (OE, 2004, p. 30) não há visão sem pensamento, mas também não basta pensar para ver, pois a visão é um pensamento condicionado, nasce por ocasião do que acontece no corpo e é excitada a pensar por ele.

Ver não é pensar e pensar não é ver, mas que sem a visão não podemos pensar, que o pensamento nasce da sublimação do sensível no corpo glorioso da palavra que configura campos de sentido a que damos o nome de ideias. Que o pensamento não são enunciados, juízos, proposições, mas afastamentos determinados no interior do Ser. (CHAUÍ, 1988, p. 60)

Comunicamo-nos com o mundo porque temos um corpo e esse corpo habita esse mundo, mas, mais do que isso, comunicamo-nos com ele pela operação perceptiva através do olhar e das sensações, que por sua vez traz uma condição afetiva. "É através do olhar que primeiro interrogamos as coisas, e devemos compreender o corpo, de forma geral, como um sistema voltado para a inspeção do mundo". (FURLAN; ROZESTRATEN, 2005, p. 61). Diante disso, volta-se na relação entre vidente e visível já citada acima, pois também o exercício do olhar nos mostra que não somos só observados pelos demais sujeitos do mundo, numa relação direta de semelhança, mas há uma correspondência entre meu olhar e as coisas existentes no mundo que faz com que todas as coisas possam me observar.

Aproximando o corpo da alma, o filósofo fala que o corpo é para a alma seu espaço natal e a matriz de qualquer outro espaço existente. É por meio da percepção que podemos compreender essa relação. Isso se configura porque a percepção aparece nas coisas e o meu corpo está entre as coisas. Sendo assim, por meio do meu corpo, ou melhor, por meio do meu 
olho, que está ligado a ele e, consequentemente, a minha alma, percebo as coisas ou elas se mostram para mim. "Quando percebo, não imagino o mundo: ele se organiza diante de mim". (MERLEAU-PONTY, CNP, apud LIMA NETO, 2012, p. 24),

"A percepção é o ato pelo qual a consciência apreende um dado objeto, utilizando as sensações como instrumento". (NÓBREGA, 2008, p. 141). É impossível separar a percepção das sensações e, mais ainda, do corpo, sobre o qual se possibilita tais sensações, isso porque as sensações não são somente um dado físico, mas sim o sentido para mim, o modo como as coisas, as pessoas, os lugares e as situações me afetam. (RAMOS, 2017, p. 45). "É preciso enfatizar a experiência do corpo como campo criador de sentidos, isto porque a percepção não é uma representação mentalista, mas um acontecimento da corporeidade e, como tal, da existência". (NÓBREGA, 2008, p. 142)

Em outras palavras, a percepção é aquilo que nos abre para a realidade, aquilo que nos relaciona com o mundo. Atrelada a ela está a expressão, nesse caso, podendo entender expressão como qualquer gesto humano. No entanto, esses dois conceitos não podem ser separados temporalmente. Para Merleau-Ponty (LI) não existe uma depois a outra, ou seja, não percebo para posteriormente me expressar. O corpo é quem expressa, é no próprio momento da 'experiência perceptiva' que já aparece a 'expressão perceptiva'; não são descoladas. "Qualquer percepção, qualquer ação que a suponha, em suma, qualquer uso humano do corpo já é 'expressão primordial'". (MERLEAU-PONTY, LI, 2004, p. 99). Essa expressão primordial citada pelo filósofo nada mais é que a ação inicial, a qual passa a dar sentido àquilo que antes não tinha, ou seja, engatilhadas pela própria percepção, lugar onde os sentidos aparecem e possibilitam a relação afetiva entre corpo e mundo. Como explica Lima Neto (2012, p. 45) "a expressão primordial é primordial não porque acha um privilégio em relação a outros atos, mas porque está relacionada à percepção; ela nasce já na percepção. “

\section{Pintura}

Diante dessas considerações, podemos partir para o desdobramento na pintura moderna, aproximando a pesquisa de Merleau-Ponty acerca da expressão artística com enfoque na pintura em si e na relação do pintor com o mundo, uma vez que "a pintura constitui uma forma peculiar de o homem aceder ao mundo e às coisas". (LIMA, 1998, p. 158)

Para Merleau-Ponty, não há um momento exato que marca o início da pintura moderna, não há nenhum marco ou acontecimento que seria possível definir uma data para tal.

E nem poderia definir, pois na sua concepção geral sobre a pintura moderna podemos dizer que ele a compreende como uma pintura de novos propósitos, mas sem marco de origem ainda definido no tempo e que ele a considera em desenvolvimento. (ALVES, 2013, p. 34-35)

Já vimos que, segundo Merleau-Ponty, a arte é o caminho que nos aproxima do mundo da percepção, e agora, veremos que a pintura é talvez o meio artístico mais eficaz do redescobrir esse mundo, pois pode-se entendê-la como sendo "uma operação reflexiva do próprio corpo" e "comunicação com o mundo através do olhar e da sensibilidade". (FURLAN; ROZESTRATEN, 2005 , p. 61). Ao dizer que a pintura possibilita a redescoberta do mundo 
percebido, está subentendido que ela, ao propiciar o acesso à percepção, acaba por desencadear a relação do pintor com esse mundo, constituída por meio do próprio processo de pintar.

O pintor oferece seu corpo ao mundo e com isso transforma esse mundo em pintura. Tal relação do seu corpo com o mundo, baseada naquele sistema de trocas entre vidente e visível, entre tocante e tocado, encontra-se na pintura. A obra de arte está colocada como campo de possibilidades para a experiência do sensível como reflexão corporal. Lembrando que o nosso corpo está no mundo e é por meio dele que o sentido das coisas, o mundo percebido, aparece, possível pelo entrecruzamento entre o corpo e a coisa.

As coisas que disputam o meu olhar na percepção natural passam para o papel uma de cada vez, e quando todas essas visões locais se reúnem na tela, através do método de projeção que as organiza, o resultado é uma imagem limpa sem os acontecimentos da visão. (FURLAN; ROZESTRATEN, 2005, p. 74)

"O pintor, qualquer que seja, enquanto pinta, pratica a teoria mágica da visão". (MERLEAU-PONTY, OE, 2004, p. 20). É pela visão que o pintor inicia a sua percepção e esta, por sua vez, vai se constituindo no momento de se expressar, nas pinceladas no quadro. Em outras palavras, por meio da percepção, o sujeito sai de si pelo olhar e perpassa as coisas, em seguida retorna a si através da expressão. Para o filósofo (OE, 2004, p. 20), a pintura jamais celebra outro enigma senão o da visibilidade. O pintor pensa por meio da pintura, no instante em que sua visão se faz gesto é que exprime opiniões sobre o mundo. (MERLEAU-PONTY, OE, 2004, p. 33). Como complementa Eliane Escoubas (2005, p. 168),

a pintura faz ver o que não se vê ordinariamente - o que não se vê de todo: ela pinta, a cada vez, o nascimento do mundo sob o olhar - o que sempre já começou quando se começa a ver o que há para ver.

A pintura aparece em um lugar privilegiado para a reflexão merleaupontyniana, isso porque "a obra de arte possibilita a experiência da percepção de modo mais intenso e vibrante". (NÓBREGA, 2008, p. 141). A pintura, para o filósofo ( $\mathrm{OE})$, não mostra uma reprodução do real, mas sim condições de uma visibilidade, uma maneira de se expressar, de se manifestar, que é adquirida pelo contato primordial do pintor (sujeito) com o mundo na sua essência através da prática da visão. Como cita Alves (2013, p. 33), "Eis que está na visão - assim como na pintura, por ser um meio de propiciar o ver - uma experiência que nos desvela os mistérios do corpo, sua comunicação com as coisas e o mundo".

Para melhor aprofundar as noções sobre a pintura, deve-se começar do grande distanciamento entre a arte clássica, de modo geral, e a pintura moderna, campo em que se encontra a pesquisa de Merleau-Ponty. No entanto, vale lembrar que o filósofo francês não acredita que a pintura moderna seja uma contraposição à arte clássica. Por mais que tenha um caráter primitivo como meio expressivo, seu ponto não é considerar o clássico como negação, mas apenas se manifestar como experiência expressiva. (ALVES, 2013, p. 60)

A pintura clássica, para Merleau-Ponty, consiste em reproduzir no papel um objeto equivalente ao que é. Isso é representar e, para então representar, o homem se utilizou de técnicas ilusionistas para conseguir esse feito, como 
é o caso da perspectiva. O surgimento desta foi o grande conhecimento para a pintura do Renascimento. Para Merleau-Ponty (LI), a perspectiva foi uma invenção do homem para conseguir projetar o mundo percebido.

A perspectiva é muito mais do que um segredo técnico para imitar uma realidade que se ofereceria tal e qual a todos os homens; é a invenção de um mundo dominado, possuído de parte a parte numa síntese instantânea da qual o olhar espontâneo nos dá, quando muito, o esboço ao tentar em vão manter juntas todas essas coisas que, individualmente, querem-no por inteiro. (MERLEAU-PONTY, LI, 2004, p. 80)

Ao questionar a perspectiva, o filósofo quer evidenciar o distanciamento dela com a apreensão do mundo percebido, com a volta ao contato primordial. O pintor, ao ter que seguir técnicas e normas no momento de pintar, deixa de perceber livremente em prol de um padrão de medidas que serão transportados para o quadro, com a finalidade de produzir uma representação objetiva, sendo a consequência disso, o desaparecimento do mundo percebido. Para Merleau-Ponty (PM, apud ALVES, 2013, p. 6061), esta seria a forma normal da expressão artística, porque já estaríamos habituados com as pinturas ilusionistas, criadas por meio de recursos técnicos inventados pelos homens e aprendidos culturalmente, não dados na natureza. É justamente por esta ideia que o filósofo se interessa pela arte moderna: não ser uma tentativa de imitação do visível, de imitação do mundo percebido, mas sim a própria manifestação do contato com esse mundo percebido, na sua forma mais sensível.

Não se trata mais de acrescentar uma dimensão às duas dimensões da tela, de organizar uma ilusão ou uma percepção sem objeto cuja perfeição seria assemelhar-se o máximo possível à visão empírica. (MERLEAU-PONTY, OE, 2004, p. 37)

Foi, então, com a chegada da arte moderna que esse cenário começa a mudar. Aquilo que outrora era desvalorizado, considerado primitivo, passa a adquirir valor. Nesse sentido, Merleau-Ponty associa a pintura moderna aos desenhos infantis. $O$ desenho infantil caracteriza-se pela expressão livre, ou seja, a criança, ao criar seu desenho, não segue regras, apenas se manifesta sem qualquer preocupação com o resultado. Segundo Furlan e Rozestraten (2005, p. 86-87), a expressão do desenho infantil revela uma percepção que não separou ainda o real e o imaginário, o sonho e a vigília, o sério e o lúdico, o objetivo e o subjetivo; é, portanto, livre. O ato da criança no desenho nada mais é que a sua maneira de perceber e exprimir o mundo, questão tão pregada pelos estudos de Merleau-Ponty acerca da relação do homem com o mundo por meio da pintura. Ou seja, da mesma forma que os desenhos infantis, a pintura moderna também se apropria dessa liberdade de perceber. "O artista moderno, pois, não se limita mais a representar uma cena única, mas exprimir uma experiência: ele narra uma experiência coextensiva com o mundo, como faz uma criança". (ALVES, 2013, p. 62)

Como já dito, com o surgimento da pintura moderna, o que se defendeu foi a percepção livre. As coisas aparecem para o sujeito de modo desordenado, num turbilhão de coisas que se confrontam diante do seu olhar. Ao congelar isso numa perspectiva ordenada, onde existe um ponto de fuga e uma linha do horizonte, perde-se o verdadeiro propósito. 
Na percepção livre, os objetos escalonados em profundidade não possuem nenhuma 'grandeza aparente' definida. Nem mesmo se deve dizer que a perspectiva 'nos engana' e que os objetos afastados são 'maiores' a olho nu do que o faria acreditar sua projeção num desenho ou numa fotografia pelo menos não dessa grandeza que seria uma medida comum aos longes e aos planos mais próximos. (MERLEAU-PONTY, LI, 2004, p. 78)

Meu olho, que é móvel, não pode se privar de seus movimentos no momento da experiência vivida. Daí a consequência de ser uma perspectiva livre. Isso só se tornou possível porque "a pintura moderna, ao interrogar nosso olhar, nos lembra de que somos seres no mundo e que podemos provar de forma livre os mais diversos meios de expressão". (ALVES, 2013, p. 62)

O pintor moderno quer ser original, como diz Merleau-Ponty (LI), ele precisa encontrar uma maneira de se comunicar sem o auxílio de uma Natureza preestabelecida. Sua expressão só ganha sentido nos outros. Não é que o pintor moderno não tenha o conhecimento sobre as mais diversas técnicas de representação, é sim uma escolha que o possibilita a não somente se deter em um meio expressivo, mas de ter liberdade para incorporar quais achar relevante. O que transporta para o quadro é o que sente, o que lhe afeta, o que advém do seu interior, da pintura dos outros e do mundo. Isso ocorre em função da pintura nunca estar acabada, mesmo porque a percepção nunca cessa.

Se nenhuma pintura completa a pintura, se mesmo nenhuma obra se completa absolutamente, cada criação se modifica, altera, esclarece, aprofunda, confirma, exalta, recria ou cria antecipadamente todas as outras. (MERLEAU-PONTY, OE, 2004, p. 46)

$\mathrm{Na}$ concepção merleau-pontyniana (OE), o inacabamento da pintura moderna não é simplesmente fazer algo inacabado por fazer, mas sim porque os pintores estão preocupados com o papel da percepção, ou seja, preocupados com o presente, com o que está se desenrolando no processo perceptivo e, concomitantemente, sendo expressado no quadro. Como ressaltam Furlan e Bocchi (2003, p. 449), para o filósofo, aquilo que se exprime constitui-se na própria expressão, não é nem anterior a ela, nem separável dela.

Nesse sentido, a percepção nunca está acabada e ela se modifica com o tempo. Isso pode ser explicado porque a própria percepção não nos oferece a ver tudo de uma única vez, pelo contrário, nos oferece por pontos parciais, que em conjunto formam-se totalidades, o que "implica em limites instáveis e sempre sendo refeitos, fronteiras dinâmicas que são reestruturadas ininterruptamente". (PALLAMIN, 2015, p. 47). Além do mais, cabe lembrar que não existe um único modo de ver e, menos ainda, uma única maneira de expressar o percebido, mesmo porque a própria expressão do mundo percebido é infinita. Merleau-Ponty (OE, 2004, p. 23) exemplifica tal ideia ao dizer que o sorriso de um monarca morto há tantos anos continua a se produzir e a se reproduzir na superfície de uma tela. Considera que é muito pouco dizer que o personagem figurado está ali em imagem ou em essência: ele próprio está na tela no que teve de mais vivo, assim que se olha o quadro.

O modo de ver, possibilitado por meio da percepção e da relação afetiva com o mundo, é o que virá a ser concretizado na tela, responsável pela relação entre o pintor e o espectador. Em outras palavras, a percepção 
"permanece como a principal operação que desenvolve a comunicação com o espectador, primeiramente porque o que ele percebe na obra inacabada são os registros do ato de pintar, o modo como o artista pintou". (ALVES, 2013, p. 69)

Como já dito, a obra não é inacabada por que falta algo para se estar pronta, mas é uma característica própria dela, que passa a ser consumada no momento da fruição, naquela percepção daquele que vê a obra e é afetado por aquilo que atingiu o pintor. $\mathrm{O}$ que em outro momento já não seria a mesma expressão.

A obra consumada não é portanto aquela que existe em si como uma coisa, mas aquela que atinge seu espectador, convida-o a recomeçar o gesto que a criou e, pulando os intermediários, sem outro guia além do movimento da linha inventada, do traçado quase incorpóreo, a reunir-se ao mundo silencioso do pintor, a partir daí proferido e acessível. (MERLEAU-PONTY, LI, 2004, p. 81)

Alves (2013, p. 69) ainda aponta que na concepção merleau-pontyniana (LI), a preocupação do pintor

se concentra na percepção do outro como uma ação necessária e que tem o poder de ultrapassar os signos dados no quadro e as coisas que já foram vistas. $O$ inacabado não louva a subjetividade ou o ego do pintor: é um apelo à percepção do outro.

Esta é a ideia embutida na pintura moderna: o quadro deve ser feito para ser percebido, para que suscite a percepção do outro. O quadro "é a corporificação de uma expressão humana exteriorizada que pretende ser interiorizada pela experiência sensível do apreciador". (ALVES, 2013, p. 101)

Tal questão apenas reforça ainda mais a intenção da pintura moderna em fazer aparecer uma expressão livre - baseada na percepção primordial - e não se utilizar de técnicas, técnicas estas ilusionistas que forçam um tipo de expressão e, consequentemente, um tipo de leitura ao espectador.

\section{Pintura e linguagem}

Para Merleau-Ponty, a pintura pode ser considerada linguagem, mas para pensar nessa relação, precisa-se antes pensar na linguagem em si.

Se quisermos compreender a linguagem em sua operação de origem, teremos de fingir nunca ter falado, submetê-la a uma redução sem a qual ela nos escaparia mais uma vez, reconduzindo-nos àquilo que ela nos significa, olhá-la como os surdos olham aqueles que estão falando, comparar a arte da linguagem com as outras artes de expressão, tentar vê-la como uma dessas artes mudas. (MERLEAUPONTY, LI, 2004, p. 76)

Merleau-Ponty (LI) separa as artes, de um modo geral, em duas partes: as artes de linguagem e as artes mudas. Nas de linguagem, consideradas por exemplo, a prosa e a poesia, o filósofo fala que os sentidos aparecem na relação entre os signos, ou seja, mais do que a significação de um signo ou de outro isoladamente, o sentido na linguagem só aparece na intersecção deles, nos espaços entre eles, no vazio onde se localiza o 
intervalo das palavras. "A palavra intervém sempre sobre um fundo de palavra". (MERLEAU-PONTY, LI, 2004, p. 71). Mais do que dizer o que está explícito nos signos, a linguagem passa a dizer mesmo quando não diz. "A ausência de signo pode ser um signo". (MERLEAU-PONTY, LI, 2004, p. 72)

Essas artes são responsáveis por dar uma vida nova à língua. Isso porque possibilitam novos significados ao leitor, já que os escritores fogem dos significados habituais das palavras ao inserirem-nas em um outro contexto. Ou ainda os novos significados podem nem mesmo terem feito parte do mundo pensado pelo escritor, mas que se encontram imbricados na relação entre os signos. "Um poema, se expressivo, se diz algo que ainda não tinha dito, se não recorre apenas às expressões instituídas, mas faz uso delas para dizer algo novo, ele nos diz algo que nunca tínhamos escutado". (LIMA NETO, 2012, p. 56).

Não temos que nos atentar a significação daquela palavra em si, mas sim nos infiltrar no conjunto onde ela está, levando em conta os gestos, a articulação. Porque é justamente nessa união que encontraremos o sentido. "A linguagem não pressupõe a sua tabela de correspondência, ela mesma desvela seus segredos". (MERLEAU-PONTY, LI, 2004, p. 72).

Por outro lado, aparecem as artes mudas. Elas se diferem por estarem associadas à sensação e aos sentidos, mas do que se atentarem aos signos. São consideradas mudas as artes como escultura, pintura, desenho, música e fotografia. Alves (2013, p. 10) complementa dizendo que para Merleau-Ponty (LI),

\begin{abstract}
As artes mudas não foram consagradas como linguagens pelos estudos específicos da época em que viveu, pois não são dadas pela estrutura de signo e significado a partir de regras culturais, como é o caso da língua - a palavra. Ele aponta, porém, que existem elementos estruturais no ver e no fazer da pintura que se assemelham à estrutura da linguagem.
\end{abstract}

A partir disso, pode-se aproximar a pintura da linguagem, ou melhor, enquadrar a pintura como linguagem, uma vez que através dela podemos ver um novo mundo, um novo significado para o mundo, possível porque a atividade do pintor se realiza a partir do que ele vê. Além disso, envolve-se a um sentido perceptivo no qual a expressão sempre está por refazer uma série de expressões anteriores.

Da mesma maneira que aparece na linguagem verbal - relações entre signos e até ausência dos mesmos com outras significações - aparece na pintura, o pintor expressa aquilo que percebe, o que ele percebe não é uma coisa isolada da outra, mas sim a rivalidade entre elas, a relação entre uma e outra. O que vemos em um quadro não é a representação do real, é uma maneira de perceber, pois "na percepção a coisa sensível aparece apenas parcialmente visível; se fosse plenamente visível esta não seria de fato algo percebido, mas sim uma ideia ou representação". (PALLAMIN, 2015 , p. 48). Isso quer dizer que o que vemos é a própria percepção do pintor estimulada por um processo que se dá em visadas parciais e vai se constituindo como todo no momento em que as pinceladas vão se concretizando.

Vendo na pintura uma maneira de perceber, como dito acima, e sendo a pintura considerada uma linguagem, na concepção merleau-pontyniana é possível afirmar que a linguagem nunca tem apenas aquela significação, 
mas vem de um conjunto que está em constante mudança, mesmo porque o sentido da linguagem apenas adquire sentido na relação com o outro, através de como essa expressão o atinge. Para o filósofo (LI, 2004, p. 73), "a linguagem significa quando, em vez de copiar o pensamento, deixa-se desfazer e refazer por ele. Traz seu sentido como o rastro de um passo, significa o movimento e o esforço de um corpo".

O que há de comum entre as artes da linguagem e as artes mudas é que ambas fazem o homem (seja leitor ou observador, pintor ou escritor) de alguma forma ser motivado pelo ato de perceber, dentro desse exercício, ele habita a experiência da expressão pelo sensível. (ALVES, 2013, p. 10)

\section{Pintura de Cézanne}

Dentro do campo da pintura, Cézanne é o pintor que merece destaque nos estudos de Merleau-Ponty. O filósofo, ao escrever a obra A dúvida de Cézanne, investiga não só o percurso artístico do pintor, como também o contexto da sua vida e qual a ligação dessa com o estudo acerca da pintura moderna. Para uma melhor compreensão sobre o pensamento moderno, parece ser fundamental aprofundar os estudos nas obras de tal artista.

Nóbrega (2008, p. 141) afirma que Merleau-Ponty (DC) ao refletir sobre a pintura de Cézanne, a entende "como configuração perceptiva cuja natureza problematiza as dicotomias entre percepção e pensamento, entre a expressão e o que é expresso". Nesse sentido, a aproximação entre essas duas figuras ocorre justamente acerca de uma afinidade entre pensamento filosófico e expressão artística: buscar as coisas no momento de aparecer. Isso porque Cézanne tinha como objetivo em suas pinturas, a mesma ideia na qual Merleau-Ponty se pautava, isto é, o mundo que Cézanne quer pintar é o mundo que Merleau-Ponty tenta descrever: o mundo pré-objetivo, onde as coisas aparecem em seu estado primordial.

A pintura de Cézanne parte dos fenômenos da percepção e está justamente aí o algo novo, aquilo que o difere dos demais pintores. Isso se dá pela tentativa constante do pintor em apreender a realidade não abandonando o campo das sensações. (LIMA, 1998, p. 155). Mais ainda, ele busca uma pintura direto da natureza e quer representá-la com um caráter inumano, vista por meio da essência, por trás da atmosfera que a envolve. E acreditava realmente nessa busca, alegando que o pintor apenas consegue pintar se voltar ao mundo percebido.

Ambos dedicaram a vida à mesma investigação, levando MerleauPonty retomar os estudos e as obras de Cézanne, como faz o pesquisador ao retomar as fontes e a bibliografia indicada ao seu objeto de estudo. Sobre esses pressupostos, Merleau-Ponty busca esmiuçar as características do pensamento moderno que interferem na vida e na produção artística de Cézanne. (ALVES, 2013, p. 47)

Como complemento, o filósofo mostra essa aproximação:

Vivemos em meio aos objetos construídos pelos homens, entre utensílios, em casas, ruas, cidades e, na maior parte do tempo, não os vemos senão através das ações humanas das quais eles podem ser os pontos de aplicação. Habituamo-nos a pensar que tudo 
isso existe necessariamente e é inabalável. A pintura de Cézanne suspende esses hábitos e revela o fundo de natureza inumana sobre o qual o homem se instala. Por isso seus personagens são estranhos e como que vistos por um ser de outra espécie. (MERLEAU-PONTY, DC, 2004, pp. 131-132)

Para Cézanne, a arte advém da expressão do percebido e como consequência disso, o pintor afirma que ela não é uma imitação, nem uma fabricação segundo os votos do instinto e do bom gosto, mas sim uma operação de expressão. Cézanne é contrário à fotografia, exatamente por acreditar que a própria coisa é a coisa que vemos e não aquela vista por meio de outros suportes, que não a nossa própria visão. O mundo não é visto à distância, através de uma fotografia, de uma perspectiva geométrica; pelo contrário, vivenciamos esse mundo, fazemos parte dele e o vemos a partir da experiência vivida, experiência esta que não segue uma lógica, nem mesmo uma técnica. "Na perspectiva vivida, não há uma ordem, as coisas aparecem a partir de um caos". (LIMA NETO, 2012, p. 48)

Merleau-Ponty (OE) mostra seu ponto de vista sobre fotografia fazendo uma comparação entre esta e um quadro, ambos com o mesmo tema: cavalos em movimento.

A fotografia mantém abertos os instantes que o avanço do tempo torna a fechar em seguida, ela destrói a ultrapassagem, a imbricação, a metamorfose do tempo, que a pintura, ao contrário, torna visíveis, porque os cavalos têm dentro deles o 'deixar aqui, ir ali', porque têm um pé em cada instante. A pintura não busca o exterior do movimento, mas suas cifras secretas. (MERLEAU-PONTY, OE, 2004, p. 42)

O pintor não se utiliza de perspectiva geométrica, assim, é através das cores que consegue atribuir sentido a seus quadros, como no caso da profundidade. Da mesma maneira, Cézanne é contrário à ideia de contornos, pois um objeto delimitado por meio de linhas pertence também a lógica da geometria e não do mundo visível. Para ele, o que importava não era o resultado da obra, mas sim uma manifestação, um fragmento da natureza, em que o que é pintado é justamente o percebido, a própria expressão.

Ao dizer que Cézanne é contrário à fotografia e, também, às técnicas dos pintores clássicos, não é que ele menospreze uma ou outra, mas apenas que tais concepções viriam a ser prejudiciais para seu projeto de arte e, até mesmo, de vida; no sentido de que, ao esquecer métodos, técnicas e regras poderia se entregar inteiramente a reaprender as coisas do mundo, as quais se encontram em sua essência.

Pode-se notar uma certa relação entre a vida de Cézanne com seu modo de pintar. Devido à sua esquizofrenia, aos seus problemas de depressão e ansiedade, a volta ao contato direto com a natureza seria uma fuga do mundo humano, uma maneira de distanciar o contato com os homens e se encontrar em si mesmo. É essa situação de fugitivo das relações humanas, a qual Merleau-Ponty acredita ser a aliada de Cézanne, pois busca na natureza o que não encontra no mundo vivido. De certa maneira, pode-se dizer que "a individualidade de Cézanne é uma característica de sua modernidade" (ALVES, 2013, p. 47), isso porque a sua vida solitária possibilitou um modo de existir que se voltava exclusivamente para a pintura. Toda obra efetuada por Cézanne demandava um intenso trabalho, 
não por dificuldade por parte do pintor, mas pelo afinco e dedicação que tinha ao reestabelecer o contato primordial através da pintura. Não é exagero dizer que o pintor vivia para pintar.

Entretanto, o sentido da sua obra não pode ser determinado por sua vida, elas apenas se comunicam. Não é porque conhecemos sua vida que conhecemos sua obra, mas sim "porque conhecemos sua obra antes e vemos através delas as circunstâncias da vida, carregando-as de um sentido que tomamos a obra". (MERLEAU-PONTY, DC, 2004, p. 136)

Ao tentar mapear o percurso do pintor, Merleau-Ponty encontra ainda mais a sua particularidade. Há uma semelhança entre a pintura de Cézanne e os impressionistas, já que ambos tomam a natureza como objeto. Além disso, foi justamente com eles que Cézanne aprendeu a utilizar-se da cor para desenhar, claro que de uma maneira muito mais ousada: enquanto os impressionistas utilizavam as sete cores do prisma, Cézanne possuía uma paleta muito mais ampla, com grande variação de tons, especificamente, dezoito cores. No entanto, segundo Alves (2013, p. 50), Cézanne observa a natureza para além das técnicas impressionistas. Lembrando que, enquanto de um lado busca-se mostrar como os objetos impressionam a visão, de outro atenta-se mais a observação da natureza em si. Ao observála, "percebendo as sensações das cores naturais, não busca adequar ou traduzir sua percepção para tela mediante uma técnica artística ou uma ciência humana". (ALVES, 2013, p. 50). A natureza chamava a atenção do pintor, pois ele

não compreendia como uma unidade composta pela soma dos entes dada facilmente aos sentidos e ao entendimento, mas como o agenciamento de um conjunto de elementos diversos, pulsantes, vibrantes e brutos, os quais uma única pincelada deveria poder restituir à tela. (ANDRADE, 2012, p. 83)

O reconhecimento de Cézanne, para Merleau-Ponty, é afirmado pela conexão entre sujeito e objeto, entre o próprio pintor e a natureza, entre ele e o mundo percebido. Tal característica possibilita uma pintura particular, capaz de nos mostrar o que não é perceptível. Este é, justamente, o elemento pautado pelo pensamento moderno: fazer ver o que ainda não foi visto. Aquilo que não era perceptível aos nossos olhos, somente passa a ser percebido quando Cézanne materializa isso em sua obra, ou seja, quando a percepção primordial se manifesta em ação pictórica, por meio dos seus gestos.

Cabe ressaltar que não é apenas Cézanne que age com esse espírito moderno, inclusive nas obras de Merleau-Ponty são citados outros pintores, mas Cézanne é o mais emblemático deles e foi quem mereceu destaque nas reflexões do filósofo, pois "interessa à reflexão do filósofo os problemas do fazer pictórico que são solucionados exclusivamente pelos procedimentos expressivos adotados pelo artista e no seu estilo". (ALVES, 2013, p. 100)

Sendo assim, Merleau-Ponty (DC) entende que esse mundo no qual Cézanne buscava representar nada mais era que o próprio mundo que lhe aparecia. O que ele fez foi libertá-lo, expressar as coisas da maneira que elas se mostravam. Daí o distanciamento das relações humanas, pois ao se afastar dos homens não haveria interferência no seu processo artístico e, como consequência, sua relação com o mundo a sua frente era a mais 
pura possível. "A vida do autor nada nos ensina e que, se soubéssemos lê-la, nela encontraríamos tudo, já que ela está aberta para a obra". (MERLEAU-PONTY, DC, 2004, p. 142)

\section{Estilo na pintura}

O filósofo pontua a questão do estilo como sendo um sistema de equivalências. Quando o pintor pinta é que expressa aquilo que está percebendo e o que revela ao espectador por meio do estilo é uma maneira particular de criar, de transpassar os sentidos. Nas palavras de MerleauPonty (LI, 2004, p. 85), o estilo é "o índice universal de 'deformação coerente' pelo qual concentra o sentido ainda esparso em sua percepção e o faz existir expressamente".

Para os modernos, não há uma regra a ser seguida no momento de pintar, apenas há a expressão, porque a pintura já existe antes da pintura. O que se pode dizer é que a expressão vai se construindo na medida em que o pintor executa as pinceladas na tela e a partir daí vai se configurando.

A expressão é uma expectativa de que a obra de arte apresenta na sua fundação a probabilidade desencadeadora da relação intersubjetiva, na qual os indivíduos significam um acontecimento anterior que gerou a obra, ou seja, a ação do pintor. (ALVES, 2013, p. 54)

Assim, Merleau-Ponty nos faz lembrar que o estilo não é premeditado, mas sim que surge a partir de um modo de se aproximar das coisas,

\footnotetext{
Mesmo quando o pintor já pintou, e se tornou em certos aspectos senhor de si próprio, o que the é proporcionado com seu estilo não é uma maneira, um certo número de processos ou de tiques que possa inventariar, é um modo de formulação tão reconhecível para os outros, tão pouco visível para ele como sua silhueta ou seus gestos de todos os dias. (MERLEAU-PONTY, LI, 2004, p. 83)
}

Sendo a ação do pintor aquela que possibilita os sentidos aparecerem para o espectador, por meio da expressão, o papel de pintor de Cézanne se enquadra aqui, diante da maneira com que o pintor olhava para a natureza, a partir da percepção primordial, expressava-se por meio de um estilo. Como explica Alves (2013, p. 56), "o isolamento e a devoção pela natureza também é uma escolha livre que Cézanne faz para elaborar seu modo de expressão artística", isto é, seu estilo.

Seu estilo acaba por estar interligado à sua percepção e, consequentemente, à sua expressão. Sendo assim, o que o pintor expressa é sempre uma resposta do mundo que é dada ao seu corpo. Pode-se dizer que é a operação expressiva do corpo, iniciada pela menor percepção, se amplifica em pintura e em arte. (MERLEAU-PONTY, LI, 2004, p. 102). Nesse sentido, o estilo é algo particular, por conseguinte, toda pintura é particular; mas, segundo o filósofo, toda pintura encontra-se dentro de uma universalidade da história da pintura, dentro do universo da cultura. Isso significa que por mais que o pintor tenha o seu sistema de equivalências, um modo de fazer pintura intrínseco a seu ser, este se insere na lógica universal da arte. Há uma unidade no estilo humano que possibilita colocar o conjunto de produções dos artistas em uma única arte. 
Mais ainda, é possível pensar que a pintura moderna, ao ter esse caráter mais livre, liberta o estilo do pintor dos modelos exteriores. No entanto, não é algo totalmente solto, no sentido de que ao ter ligação com a percepção, a pintura se prende à relação do pintor com o mundo e mais, com a sua vida. "Seu estilo não é o estilo de sua vida, mas faz com que esta também tenda para a expressão". (MERLEAU-PONTY, LI, 2004, p. 95). Ou seja, ao vermos uma pintura, vemos um estilo e esse estilo nada mais é que parte visível do processo perceptivo do pintor, encarnada na forma de arte como linguagem. 


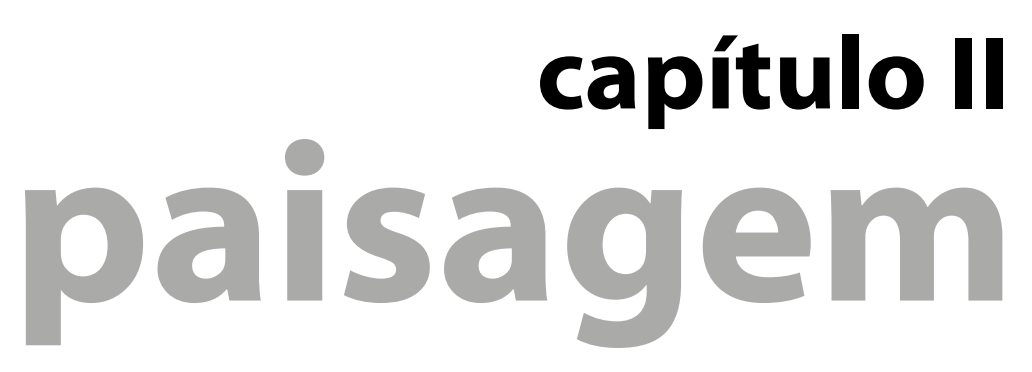


A noção de paisagem não é única e estática, tem uma ampla abrangência - percorre o campo da biologia, da geografia, da estética, da psicologia, da arquitetura, da arte - e passa, desde as primeiras reflexões, por diversas transformações.

No Ocidente, essa noção surgiu associada a arte, em específico, a pintura em torno de temas relacionados a natureza, como montanhas, florestas, rios, lagos. De um modo mais geral, a palavra paisagem em sua origem, no século XV, é referente ao sentido de "quadro representando uma região". (ROGER apud ALVES, 2001, p. 67).

A partir do século $X V$, há a distinção do léxico e o termo paisagem aparece referente a um lugar. Advém da palavra terra - no sentido de território, país pays ou land que significa uma região conhecida daquele que percebe. Nas diversas línguas ocidentais conhecidas por paysage, em francês; paisaje, em espanhol; paesaggio, em italiano; paisagem, em português; landscape, em inglês e landschaft, em alemão. (ROGER, 2000, p. 33).

Esse estudo dos léxicos leva a uma investigação do que é a paisagem, numa tentativa de atualizar o conceito a partir de investigações estéticas. Nesse sentido, no século XX, Alain Roger (2000) defende a hipótese culturalista, a qual diz respeito à paisagem, seguindo a ideia de que "a noção de paisagem nasce em primeiro lugar no olhar que se modela pela percepção, e que se amplia a partir desse contato com as artes em geral e com a pintura em particular" (SCHENK, 2008, p. 13). Alain Roger (2000, p. 33) retoma o termo artialização criado por Montaigne no século XVI, mostrando que as paisagens são aquisições, ou melhor, invenções culturais as quais podemos datar e analisar e que a nossa experiência, visual ou não, é modelada por modelos artísticos. Além disso, o autor complementa "o país é, de alguma maneira, o grau zero da paisagem, o que precede a

[1] "Le pays, c'est, em quelque sorte, le degré zero du paysage, ce qui precede son artialisation, qu'elle soit directe (in situ) ou indirecte (in visu)." (ROGER, 2000, p. 33) artialização, seja ela direta (in situ) ou indireta (in visu) ${ }^{[1]}$ " (ROGER, 2000, p. 33). Ou seja, há duas maneiras de artializar um pedaço de terra (país) para transformá-lo em paisagem. A primeira, in situ, sendo a operação artística diretamente aplicada ao próprio objeto natural no terreno, por exemplo, os jardins e a land art; e a segunda, in visu, a nossa percepção estética da paisagem que, por mediação indireta, é modelada pelas suas diferentes formas de representação na arte.

Com essas colocações, o que se torna evidente é a relação da paisagem com a experiência cultural, não como algo já dado, mas adquirido por meio de uma construção perceptiva, de uma relação entre quem observa e o que é observado. Conforme Andriolo (2016, p. 94) não são apenas coisas físicas (a natureza, as montanhas, os lagos), mas resultado de processos sociais que envolvem a noção de mundo percebido.

A construção da paisagem é parte da construção de si mesmo no mundo, mobilizando não só a percepção, mas uma condição existencial muito ampla e que só é possível numa realidade entre sujeitos e temporalidades múltiplas, que envolve as subjetividades, além da sociabilidade e de uma dimensão que ultrapassa o indivíduo, mas a ele se apresenta e pode ser percebida, que é social e histórica. (SANDEVILLE JR., 2012, p. 210)

Cabe ressaltar que essa ideia associada à uma dimensão que perpassa a noção de território físico, faz parte do processo de transformação do 
conceito de paisagem, cujas noções colocadas desde o século XV foram sendo retomadas e revistas séculos depois. Pode-se dizer que esse processo é resultado da dinâmica da evolução, na qual a pintura, com suas técnicas tradicionais, não consegue expressar as paisagens de um mundo em contínua mudança. O conceito, então, transforma-se, ao passo que a arte acompanha essa mudança. "As paisagens são criadas pelas pessoas através da sua experiência e pelo seu envolvimento com o mundo que as rodeia." (ALVES, 2001, p. 68)

Não apenas uma representação de uma região em pintura, tampouco uma determinada região, a nova paisagem passou a questionar algumas reflexões e abranger outras dimensões, como a cultural, a histórica e a social. Uma questão é quanto à distinção entre natureza e paisagem, reforçando a ideia de que paisagem não é natureza. Euler Sandeville Júnior (1999, p. 22) apresenta uma distinção entre natureza e artifício - podendo incluir a paisagem nessa última -,

Por natureza nos referimos normalmente à matéria e a vida organizadas sem a interferência humana ou com o mínimo de interferência que não the altera substancialmente as características. Por artifício, nos referimos ao trabalho e imaginação humanos que são transformadores das condições da natureza. (SANDEVILLE JR., 1999, p. 22)

Toda apropriação da natureza, inclusive intelectual ou meramente designativa, paradoxalmente, acaba sendo um artifício. (SANDEVILLE JR., 1999, p. 23)

A outra questão é pensar a paisagem como uma construção cultural e histórica. Segundo Luciana Schenk (2008, p. 11), a paisagem é vista como algo relacionado com a história, com a soma dos tempos que conforma os lugares, o que implica numa construção cultural e num modo de perceber essa relação.

Enquanto imagem de uma dada realidade, a paisagem vem carregada de um forte conteúdo subjetivo, uma vez que cada pessoa a aprecia de um modo íntimo, valorizando segundo seus interesses, sua cultura, sua história pessoal e capacidade de observação, a seleção da cena a ser definida como uma paisagem e cada um de seus elementos componentes. (SANDEVILLE JR., 1999, p. 37)

Pensar nessa frase "a paisagem enquanto imagem", como citado acima, é compreender a paisagem a partir da noção de imagem. Sobre as reflexões do filósofo Merleau-Ponty, o processo de construção de uma imagem se baseia nas dimensões do processo perceptivo, onde há uma relação intrínseca entre o sujeito, o lugar e contexto histórico-cultural. Para esse filósofo, a construção de uma imagem, em específico da pintura, é o meio mais eficaz de redescobrir o mundo, de compreender esse mundo que vai para além dos nossos olhos, que se constitui em essência, longe dos juízos e valores já empregados, chamado por ele de mundo percebido ou primordial.

A paisagem se mostra para o sujeito que a percebe na interação entre quem vê e quem é olhado, - como Merleau-Ponty denomina de "a vinda a si do visível" - inclusive, ela se mostra de modos distintos conforme a 
percepção de cada sujeito. "A paisagem é um mundo relacional, é o mundo do 'entre nós"'. (SANDEVILLE JR., 2012, p. 208). Por mais que sempre esteja relacionado a um lugar físico, a um território, a paisagem se constitui nos aspectos perceptivos, ou melhor, a paisagem se constitui no encontro dessa realidade física com a dimensão perceptiva. (SANDEVILLE JR., 1999, p. 46). Assim como para Merleau-Ponty a pintura não mostra uma reprodução do real, mas sim uma maneira de se expressar, a paisagem também não é única e fiel a realidade física, advém da manifestação do sujeito frente ao observado. Diante disso, pode-se pensar a paisagem como um meio de o sujeito ter consciência da realidade.

A paisagem, esta "evidência sensível", é a resultante de uma série de relações e combinações de várias ordens e naturezas impressas sobre a Terra. Tais impressões podem e devem ser reconhecidas, lidas, decifradas, interpretadas, para se atingir a realidade mais interna que por elas se manifesta. (BARTALINI, 2013, p. 40)

Arley Andriolo (2016), cita que autores mais recentes têm vinculado a noção de paisagem a três referenciais: o simbólico, o iconográfico e o ambiente geográfico.

Os organizadores afirmam que a paisagem é uma imagem cultural, o meio de representar ou estruturar simbolicamente os lugares. De tal modo que a pintura, ou outros objetos icônicos, é parte importante da relação entre o observador e o ambiente. (ANDRIOLO, 2016, p. 94)

Em todo o percurso colocado acima, nota-se que a noção de paisagem aparece bastante vinculada a arte, a começar pelas primeiras ideias sobre o que viria a ser esse conceito. A relação com a pintura, inicialmente e, de certa maneira, exclusivamente, foi seguida a diante e os desdobramentos que aparecem mostram o vínculo com a arte, por exemplo, por meio de associações com o iconográfico, a imagem, a representação. Bartalini (2013, p. 41) cita Georg Simmel (1988), dizendo que toda vez que se apreende uma paisagem e não um mero agregado de objetos, está-se diante de uma obra de arte in statu nascendi. Não é preciso ser, de fato, um artista para que essa experiência de apreensão aconteça, pois, a forma artística se torna viva em nós, mesmo sem poder aceder à criatividade própria de um artista. "A paisagem exige um estágio intermediário de elaboração da imagem, antes de se tornar uma pintura". (BARTALINI, 2013, p. 41)

Pitoresco

"A paisagem do século XIX não pode ser reduzida à chave naturalista. Ela depende de modelos de interpretação, que lhe fornecem imagens". (BELLUZO, 2008, p. 44). Mais do que se atentar ao registro da paisagem no contexto científico, deve-se pensá-la como uma construção historicamente localizada. Como afirma Belluzzo (2008, p. 44), não resta dúvida de que a paisagem pertence aos sentidos, pois é construída por alguém que a observa e a traduz e que já vem carregado de uma bagagem, de uma cultura, de um aprendizado, de uma técnica.

Para a construção da paisagem, a qual vimos ser a construção de uma imagem, aparece o modo de apreciação do pitoresco, que concilia as concepções topográficas, da geografia, da vegetação, com os costumes da vida humana do Brasil. 
A noção do pitoresco, "cuja teoria e prática foram a maior contribuição que a Inglaterra deu à estética europeia" (BELLUZZO, 1999, v. 3, p. 11), é marcada pelos valores pictóricos sobre a natureza observada e vigorou na Inglaterra durante o século XVIII e os primeiros trinta anos do século seguinte. Ocorreu, de certo modo, uma união entre a arte e a natureza, em que se juntaram poetas e pintores, arquitetos e jardineiros, viajantes, especialistas e diletantes.

Trata-se de uma categoria estética, à qual podemos atribuir o valor de um instrumento que serve especificamente ao propósito de apreender as experiências vividas num cenário diferente ao do mundo cotidiano do viajante. (DIENER, 2008, p. 60)

Em partes, o termo pitoresco é usado para referir-se a um campo que está dentro da estética, mas é também utilizado para caracterizar um modo específico de apreender a realidade, que não é através dos artifícios das ciências, mas que pode transpassar a informação de forma amável, e, mais ainda, de fácil compreensão.

Sua própria palavra diz respeito à pintura e, com isso, a ideia que surge é que existe uma analogia entre a pintura da paisagem e o desenho dos jardins. A sua primeira manifestação ocorre historicamente na prática do arranjo dos jardins ingleses, expressando anseios estéticos. Essa prática foi um artifício de tentar arranjar a natureza por imitação da arte e entender a natureza como parceira do homem.

Foi a partir disso, nos meados do século XVIII, que o pitoresco se consolidou como um conceito de teoria da arte. O início surge com os escritos de William Gilpin (1792) e nas últimas décadas do século passou a ser identificado como uma categoria estética a se localizar entre o belo e o sublime.

Gilpin (DIENER, 2008, p. 63), para descrever a paisagem inglesa, busca articular a natureza de modo a aproximá-la dos princípios de composição da pintura. Para ele, a natureza é admirável, capaz de se harmonizar com infinita variedade, mas dificilmente chega a produzir um conjunto harmonioso. Sempre há um traço desajeitado que atravessa o conjunto ou algo mal localizado, como uma árvore, por exemplo. Em resumo, sempre existe algo que não é como deveria ser. Nesse sentido é que o pitoresco adquiriu valor normativo e é justamente na elaboração da harmonia do conjunto que entra a mão do artista, sendo capaz de identificar toda a variedade e todos os ingredientes que a natureza oferece para tal.

A escolha dos elementos que irão compor a pintura é bastante importante. São escolhidos os melhores pontos de vista da paisagem para ser emoldurado no quadro. Pode ser considerada, conforme Miguel Luiz Ambrizzi,

a fruição detalhada de uma realidade, apreendida como a metáfora do jardim inglês, uma ordem natural encontrada numa aparente desordem estética racional. Não é de uma beleza geométrica que se fala, mas de um sentido de fruição pelo valor do próprio mundo natural (AMBRIZZI, 2011, p.20)

Entretanto, caracterizam-se por uma visão desinteressada com relação

à realidade, uma vez que apreendem a natureza a partir de elementos 
emprestados da arte. É a ideia de compreender o observado, não pelo que ele simplesmente é, mas sempre associando a outras questões, percebidas através de códigos culturais, de algo preexistente que constitui um repertório artístico. É a compreensão de que toda paisagem vem de um encontro entre o que é dado e o que a cultura legitima acerca do que é visto. Em outras palavras, a visão pitoresca "ensina que a dimensão sensível inerente a toda e qualquer paisagem depende também da educação visual do observador". E mais, "a paisagem pitoresca oferece evidências do que poderíamos chamar imagens prévias criadas pela pintura, agindo no momento da percepção do mundo sensível." (BELLUZZO, 1999, v. 3, p. 19)

Em síntese, pode-se fazer uma aproximação mais abrangente sobre o que é o termo pitoresco. Segundo, Pablo Diener (2008), algo que fazia referência à pintura e que foi se transformando até chegar a evocar aquilo que atrai e entretêm a atenção do olhar e que estimula os sentidos do espectador.

Mais do que isso,

as implicações do pitoresco abrangeram diversos campos da cultura, desde os arranjos de jardins à literatura e da moda à política. Desta maneira, o pitoresco contribuiu decisivamente para a consolidação de uma forma de apreensão e concepção do mundo pautada pela visualidade, em que se interpretava a realidade por meio de referenciais fornecidos pela linguagem artística. (COSTA, 2015, p. 221)

Conforme Thiago Costa (2015, p. 231), a natureza e a realidade passam a ser aperfeiçoadas por intermédio de um ideal estético, que faz com que a imaginação exerça papel fundamental na elaboração do registro pitoresco.

Muito utilizado no campo da arte a partir do século XVIII, esse ideal estético cunhado pelo pitoresco se fez presente no percurso de muitos artistas, sobretudo na prática de viagem dos chamados artistas-viajantes.

\section{A prática de viagem}

A experiência de viagem pode ser abordada tanto com base no mundo dos viajantes, como no mundo dos turistas. Em um primeiro momento, a pesquisa se volta para a compreensão dessa experiência desde seus primórdios com os viajantes. Segundo Andriolo (2011, p. 114), para entendêla é preciso compreender a relação do corpo em situação histórica.

Até o século XVIII, havia um predomínio da cultura oral, fortemente difundida na Idade Média. Nessa época, a relevância se dava para o papel da memória, em que o sentido da audição se sobressaia do sentido da visão. É, justamente, nesse mesmo século XVIII, que historiadores o têm qualificado

Como a superação de uma cultura outrora primordialmente oral e tátil para outra em que a visão começa a tornar-se o instrumento sensório dominante, como resultado da difusão da tipografia e do desenvolvimento do moderno espírito científico. (ANDRIOLO, 2011, p. 114)

Sendo assim, o viajante que antes se baseava na conversa, agora sente a necessidade de olhar, seu mundo e sua percepção passam a se constituir 
por imagens. Houve aí uma transformação no processo perceptivo, uma nova sensibilidade com relação ao mundo percebido, a qual se relaciona intrinsecamente ao contexto histórico da sociedade e à maneira como a cultura forja uma direção.

As viagens têm parentesco com o olhar porque ambas são expressões distintas de uma mesma experiência do tempo. No movimento do olhar, qualquer sinuosidade destoante da paisagem familiar converte a percepção cotidiana em outro olhar. (ANDRIOLO, 2011, p. 124)

Com o domínio da visão, os viajantes passam menos a confiar em livros ou documentos escritos e vão em busca de criar suas próprias anotações e seus próprios conhecimentos. Foi a partir dessa mudança de postura que surgiu uma nova prática de viagem, o Grand Tour. (ANDRIOLO, 2011, p. 117). Vale ressaltar que esse cenário, onde a visão ganha força e onde o Grand Tour se insere, é o cenário de mudança na estrutura socioeconômica, processo advindo da Revolução Industrial. O novo tipo de viajante, denominado grand tourist, é "um viajante dispondo acima de tudo de recursos e tempo nas primeiras viagens registradas pela historiografia da prática social de viajar por puro prazer e por amor à cultura." (SALGUEIRO, 2002, p. 291). Ele busca lugares onde a arquitetura ainda tem influência da cultura clássica e não sofreu muito com a interferência do novo sistema. Os destinos que mais atendem a essa questão são as cidades italianas, como Veneza, Roma, Florença e Nápoles.

São os ingleses, os primeiros a utilizar o termo "tour" para designar o giro pelos países europeus tendo a mesma cidade como ponto de partida e chegada cujo objetivo fundamental era o de observar "in loco" e reconhecer as relíquias e antiguidades que se espalham pela península italiana. (PICCOLLI, 2001, p. 35)

Entretanto, não é que a atividade dos viajantes tenha começado apenas com o Grand Tour, é simplesmente que essa transformação sociocultural e perceptiva veio de um processo de consolidação do ato de olhar. Em outras palavras, a prática de viagem se deu e, até hoje, se dá de diversas formas, além do contexto cultural são impulsionadas pelo comprometimento, pela motivação, pelas próprias condições da viagem.

[...] as viagens eram fundamentalmente meios de conhecer e mapear o mundo, de atingir outros lugares e melhores condições de sobrevivência, hoje elas se constituem no substrato da vida contemporânea. (PIMENTEL, 2001, p. 82)

Nessa ideia de conhecer e mapear o mundo é que se inicia o percurso dos viajantes. Inclusive, viajantes que vinham conhecer o nosso continente.

Prática de viagem na América

No decorrer dos séculos, os inúmeros viajantes que percorreram o Brasil registrando o que viam produziram uma grande quantidade de documentos escritos e visuais que carregam uma variedade de imaginários, de olhares e de relações que se estabeleceram no período de suas permanências nestas terras. (AMBRIZZI, 2011, p. 6) 
O conhecimento do continente americano por esses viajantes estrangeiros, artistas, cronistas e cientistas vem desde o século XVI com o aparecimento dos grandes navegadores e as primeiras imagens da América surgem aqui, com Amerigo Vespucci. Segundo Ana Maria Belluzzo (1999), os desenhos nessas expedições traziam um teor mais descritivo, visto que a observação era voltada para fins práticos das rotas marítimas e a cartografia acabou sendo o instrumento de orientação. No final do século XVI e no século XVII, o olhar dos europeus sobre o novo continente volta-se para a terra e para o índio americano. Um olhar enquanto objeto de cobiça e de desejo, um misto de curiosidade e impulso de conhecimento, correspondentes às intenções de posse e conquista.

A partir da vinda da corte portuguesa ao Brasil, no século XIX, outro período é marcado significativamente pela vinda de artistas profissionais ao país. As expedições, de acordo com Belluzzo (1999), vinham em busca de entender esse território ainda desconhecido pelo mundo europeu. Com o domínio do desenho e visão educada na estética do pitoresco, tais artistas buscavam desfrutar das paisagens características. Segundo palavras de Pablo Diener (1997):

Lo que el artista viajero procura en América también tiene connotaciones ideales $\mathrm{o}$, al menos, intenta encontrar imágenes con un valor generalizador: un paisaje que resuma las singularidades de la fisonomía regional, individuos representativos de una determinada sociedad, manifestaciones emblemáticas de su historia y de su cultura material, en fin, todo lo que permita construir una identificación típica de un país o de una región. (DIENER, 1997, p. 296)

A paisagem pode ser vista também como

[...]o ponto de encontro entre as descrições textuais, tanto do tipo naturalísticas (científicas) quanto do tipo artísticas. Assim, vimos enunciar-se um problema de contemplação em meio ao universo da observação, numa oscilação permanente entre o desejo documentário (descrever, contextualizar) e o desejo de atemporalidade (a imagem contemplativa da paisagem "brasileira") (AMBRIZZI, 2011, p.8)

Todos os herdeiros da tradição artística traziam na bagagem o mesmo meio de que dispunham para realizar a primeira aproximação com o mundo desconhecido, a representação gráfica. Tinham como objetivo enfrentar um cenário não habitual e preservar a memória visual para quando não estivessem mais diante do observado.

O grande território brasileiro, ainda mal conhecido, desperta curiosidade nos europeus voltados ao conhecimento da natureza, mais notadamente durante o século XIX. Não só conhecimento científico, muitos buscam o que o novo continente pode oferecer de peculiar e distinto do que já possuem. $O$ interesse pelo conhecimento científico passa a se aliar à prática de viagem. "Os viajantes que chegaram ao Brasil nas primeiras décadas do século XIX poderiam conferir imagens e opiniões, que circularam pela Europa e thes contrapor fatos da experiência". (BELLUZZO, 2008, p. 44).

Diante do que lhe é estranho, o olhar do sujeito é impactante. Primeiro, é preciso reconhecer nessa estranheza a ausência da rede de significações imposta pela cultura, pelo aprendizado. A visibilidade diminui na medida em que o homem, engajado pelo hábito, passa a apreender através dos 
sentidos internalizados. Ao contrário, essa visibilidade aumenta quando o viajante deixa esse "mundo externo" tomar conta, tornando um convite à aventura do desconhecido. Ele traz, do lugar estranho e do lugar distante, as motivações poéticas para a sua imaginação.

A distinção entre o plano estético e o plano científico, sob a dicotomia do sentir e do conhecer, segregou as obras revelando-as comprometidas com o estilo pitoresco ou com o estilo naturalista. Este, tendendo a uma abordagem despojada do pressuposto artístico e supondo uma observação direta das verdades do mundo, o que entendem ser a descrição da natureza; e aquele, apoiando-se em padrões estéticos da pintura ao produzirem imagens do país que está sendo desvelado.

\section{Rugendas}

O Brasil visto pelos artistas estrangeiros por meio da visão pitoresca foi figurado com imagens sedutoras. A difusão no exterior de tais imagens contribuiu para a formação histórica da nação. Um desses artistas foi o alemão Johann Moritz Rugendas (1802-1858). Sua relação com o Brasil ocorre quando ainda é muito jovem. Os relatos da viagem ao Brasil, de 1817 a 1820, de Johann Baptist von Spix (1781-1826) e Carl Friedrich Philipp von Martius (1794-1868) serviram de incentivo a Rugendas, o qual, em 1821, firma um contrato na Alemanha com a expedição naturalista organizada pelo Barão de Langsdorff. Nessa expedição, que faz parte do grande projeto de reconhecimento científico do Brasil, Rugendas atuará como ilustrador. Suas habilidades artísticas, "em particular a perícia em desenhar e a agudeza da sua observação, respondiam positivamente às necessidades exigidas de um ilustrador de expedição científica". (DIENER; COSTA, 2002, p. 13)

A expedição chega ao Brasil em março de 1822, no Rio de Janeiro, em pleno contexto efervescente da independência do país. No começo da viagem, Rugendas se prendeu a representar plantas e animais contribuindo para o reconhecimento naturalista da nova terra. Nessa fase, o pintor já se encontrava insatisfeito com Langsdorff. A partir de então, não estando mais exclusivamente a serviço da expedição, Rugendas passa a fazer viagens pelo país e tomar atitudes por conta própria, isso se deu durante um ano e meio, desde parte de 1822 até 1824 . Nesse período, sua estada no Rio de Janeiro lhe permitiu acompanhar o processo de independência do país de perto e adquirir contato com os integrantes da Missão Artística Francesa, que tinham chegado ao Brasil em 1816. (SANDEVILLE JÚNIOR, 1999). A expedição de fato, começou em 1824 e prometia percorrer São Paulo, Minas Gerais, Goiás e Mato Grosso, no entanto, somente foi para Minas Gerais. Para Rugendas, esse percurso seria enriquecedor para sua vida artística e em troca realizara o trabalho para Langsdorff. (DIENER; COSTA, 2002)

Nesse percurso o artista conhece Ouro Preto e aí se pode ver que a maior preocupação com as representações mineiras se pautava com a atividade mineradora ou atividade agrícola quando aquela passa a perder a hegemonia. Além disso, pode-se contar com paisagens feitas no percurso da viagem com característica pitoresca.

Em novembro de 1824, ocorre uma briga entre Rugendas e Langsdorff. Depois de dois anos de insatisfação acumulada, Rugendas se desvencilha da expedição, tendo a acompanhado até Diamantina. Segundo Diener e Costa (2002, p. 20-21), pouco se sabe sobre seu percurso após o 
desligamento da expedição. Mas se sabe, através de um escrito de Langsdorff, que em fevereiro de 1825, Rugendas se encontrava em Ouro Preto, lembrando que ele não estava sozinho, mas sim com o zoólogo Ménétriès e o botânico Riedel.

Durante esse período no país, com e sem a expedição de Langsdorff, Rugendas vai descobrir uma dupla vertente do seu fazer artístico. De um lado, o de artista-viajante que busca conhecer os lugares mais distantes e desconhecidos e, de outro lado, o de ilustrador científico que produz imagens para acompanhar as descrições de publicações sobre botânica e geografia. (DIENER; COSTA, 1998, p. 18)

Logo, em 1825, retorna a Europa. Especificamente de 1825 a 1828 vive em Paris, Ausburg e Munique e se dedica a produção do seu livro Voyage Pittoresque dans le Brésil. O editor, que aceitou o projeto ambicioso de Rugendas de publicar o livro, foi o francês Engelmann. O projeto contou com 22 litógrafos e se iniciou em 1827. O fascículo, finalizado em 1835, contava com 100 litografias e, no total, foram produzidos 20 exemplares nas duas línguas mais difundidas na época, francês e alemão.

Rugendas interveio inicialmente em todos os aspectos da produção da obra, desde a elaboração dos desenhos preparatórios e o cuidado da fabricação das gravuras propriamente - um assunto que conhecia em profundidade desde a sua infância - até a redação dos textos, para a qual contou com a colaboração do seu amigo, o escritor Victor Aimé Huber. (DIENER; COSTA, 2002, p. 24)

Quantos às imagens publicadas no Voyage Pittoresque dans le Brésil, deve-se ressaltar que em função da interferência de litógrafos nos registros originais de Rugendas não se pode assegurar a veracidade da publicação, ou melhor, a fidelidade aos registros próprios do artista. Cabe apontar que durante toda essa passagem pelo Brasil, Rugendas apenas produz desenhos, que raramente são coloridos com aquarela. Mesmo esses desenhos tendo um caráter de extrema importância, não são o resultado final do trabalho de um artista-viajante. Era preciso editá-los e complementá-los para se tornarem atrativos ao público, "o que trouxe como consequência uma marcada deformação em sua espontânea recepção do país em benefício de concessões ao gosto europeu da época". (DIENER, 1996, p. 55)

Embora houvesse um certo compromisso por parte do litógrafo em guardar as informações da imagem em que se baseava, eventualmente garantida por uma supervisão do autor da mesma, a reprodução técnica implicava em maiores ou menores alterações de acordo com a habilidade, gosto e interpretação de outro artista. (ZENHA, 2002, p. 139)

A própria supervisão de Rugendas acabou não sendo muito efetiva durante todo o processo de produção, o que deixa uma interrogação ainda maior quanto à verossimilhança das imagens.

Em 1828 vai para a Itália, onde tem contato com outros tipos de técnicas por exemplo o esboço feito a óleo - e adquire intimidade com o trabalho dos artistas pitorescos ingleses, franceses e alemães.

Foi ali que teve contato com as vanguardas artísticas da época e onde, em última instância, aprendeu a pintar. Até então, tinha sido 
um fiel discípulo da escola alemã, na qual predominava a preferência pelo desenho como cristalização da ideia artística e para a qual a cor estava sujeita a desempenhar um papel secundário. (DIENER, 1996, p. 49)

As questões acima vieram a corroborar com o seu segundo projeto de viagem, dessa vez para a América do Sul e com o auxílio e motivação de Alexander von Humboldt (1769-1859), cujo contato se inicia a partir de 1825. Com um grande arsenal de informações sobre o continente americano devido à amizade com Humboldt, Rugendas decide fazer essa segunda viagem com o intuito de reunir material para uma nova publicação, semelhante a já publicada Voyage Pittoresque dans le Brésil, agora sobre o continente americano e com uma nova mudança também proporcionada pelo contato com o artista alemão: começa a sentir a necessidade de desenvolver sua habilidade como desenhista para a pintura, para que sua obra possa ganhar mais autonomia. (DIENER; COSTA, 1998, p. 19)

Sobre Humboldt, vale ressaltar o seu interesse pelo continente americano e, inclusive, pelo Brasil. A viagem desse naturalista ficou bastante conhecida e marca a descoberta científica do novo mundo. Ocorreu de 1799 a 1804, mas, especificamente no Brasil, por razões políticas daquele momento, o Reino de Portugal impediu a entrada de Humboldt no Brasil temendo que ele fosse um espião alemão. (VITTE; CENE, 2012, p. 79).

O grande interesse que Humboldt manteve sobre o país, demonstrado em suas obras, foram os incentivadores para que um número considerável de viajantes viesse até aqui. Seus escritos "deben ser considerados como el impulso fundacional para pensar el registro visual de la naturaleza americana". (DIENER, 1997, p. 291). Isso porque para ele era necessário desenvolver uma corrente de pintura de paisagem para os trópicos. Essa corrente advém de uma união entre arte e ciência. $O$ conhecimento científico é um ponto fundamental para se compreender uma paisagem, mas é o ato artístico que entra como processo para essa compreensão e apreensão da natureza. É por meio do conhecimento científico, ou seja, do estudo da geografia, do clima, da vegetação, que o artista terá mais base e liberdade para construir paisagens plausíveis. A intenção de Humboldt, através dessa união, não é fazer com que os artistas-viajantes produzam paisagens rigorosamente iguais a realidade, mas que eles possam criar composições possíveis para aquele ambiente em específico, utilizando de todo seu conhecimento geográfico para selecionar o que poderia compor tal paisagem.

De este modo, el pintor no se comportaria como un esclavo de lo que existe, sino como un creador de lo que podría ser. A partir de un conocimiento científico, el artista puede y debe completar su obra com todo aquello que podría incluir un paisaje, siguiendo las premisas de la geografia física. (DIENER, 1997, p. 294)

O autor ainda acrescenta que, para Humboldt, "la interacción de las diversas variables de la geografia determina la configuración del paisaje." (DIENER, 1997, p. 293). Os artistas, ao saberem diferenciar as paisagens tropicais, entendendo-as cientificamente, passam a reproduzir na pintura a natureza típica da América e não reproduzir aquela já conhecida da Europa.

Nesse sentido, a viagem de Rugendas à América que tem início em 1831, passa a seguir esses preceitos colocados por Humboldt. Nela, o 
artista-viajante parte com uma visão minuciosa para a natureza, para as formas da vegetação e do relevo, em busca daquelas paisagens que sejam mais completas quanto ao grau de características geográficas típicas, isto é, regionais. O primeiro destino é o México, mas a seguir passou pelo Chile, Peru, Bolívia, Argentina, Uruguai e por fim, pelo Brasil. Foi uma viagem feita por conta própria e, segundo Pablo Diener (2007, p. 286), pode ser considerada a mais ampla trajetória feita por um artista individualmente, tendo duração de 15 anos.

Efetivamente no Brasil, Rugendas permaneceu pouco tempo, cerca de um ano, entre 1845 e 1846. Com estadia apenas no Rio de Janeiro, para além de continuar seu périplo pela América, o artista aproveitou as oportunidades para expor suas obras na academia carioca e para pintar retratos da família imperial. (DIENER, 1996, p. 49)

Nessa segunda viagem, Rugendas incorpora outra maneira de representar, como já citado. Enquanto que na primeira viagem ele utiliza apenas desenhos e, raramente, aquarela; nessa ele passa a realizar a pintura a óleo para se expressar diante do observado. Assim, muda-se não só o meio de se expressar, mas também a relação do artista com o ambiente em que está inserido. O tempo de contato aumenta, o modo de perceber se altera e, consequentemente, a representação se altera, no entanto, o modo de apreciação europeu ainda é o mesmo. Outra mudança entre a primeira e a segunda viagem e a influência de Humboldt se dá quanto ao cuidado de mostrar as representações de forma conexa, ou seja, uma relacionada com a outra possibilitando encontrar uma totalidade entre as paisagens, como aconteceu na segunda viagem. Já na primeira, "as representações caminham mais em direção de ilustrações de espécimes isoladas". (TELÉSFORO; LOURENÇO, 2010, p. 9)

Pablo Diener e Maria de Fátima Costa (1998) evidenciam uma mudança quanto ao percurso artístico de Rugendas, que passa de desenhista para pintor. Os dois pontos fundamentais dessa transformação foram a amizade feita em Paris com Humboldt e a viagem à Itália. Esses fatos quebram com a sua tradição artística baseada no esforço sobre a linha, advinda de sua dedicação ao desenho quando ainda era muito jovem e pelas influências de sua família, do seu primeiro mestre Adam e da Academia de Munique. A evidência dos autores reforça ainda mais a distinção entre uma e outra viagem ao Brasil, a primeira com caráter de desenhista e a segunda, de pintor.

A intenção de publicar seu mais novo trabalho na Europa acabou não se concluindo e Rugendas opta por vender sua obra à coroa da Baviera, tendo a esperança de que venham a ser publicadas algum dia. 


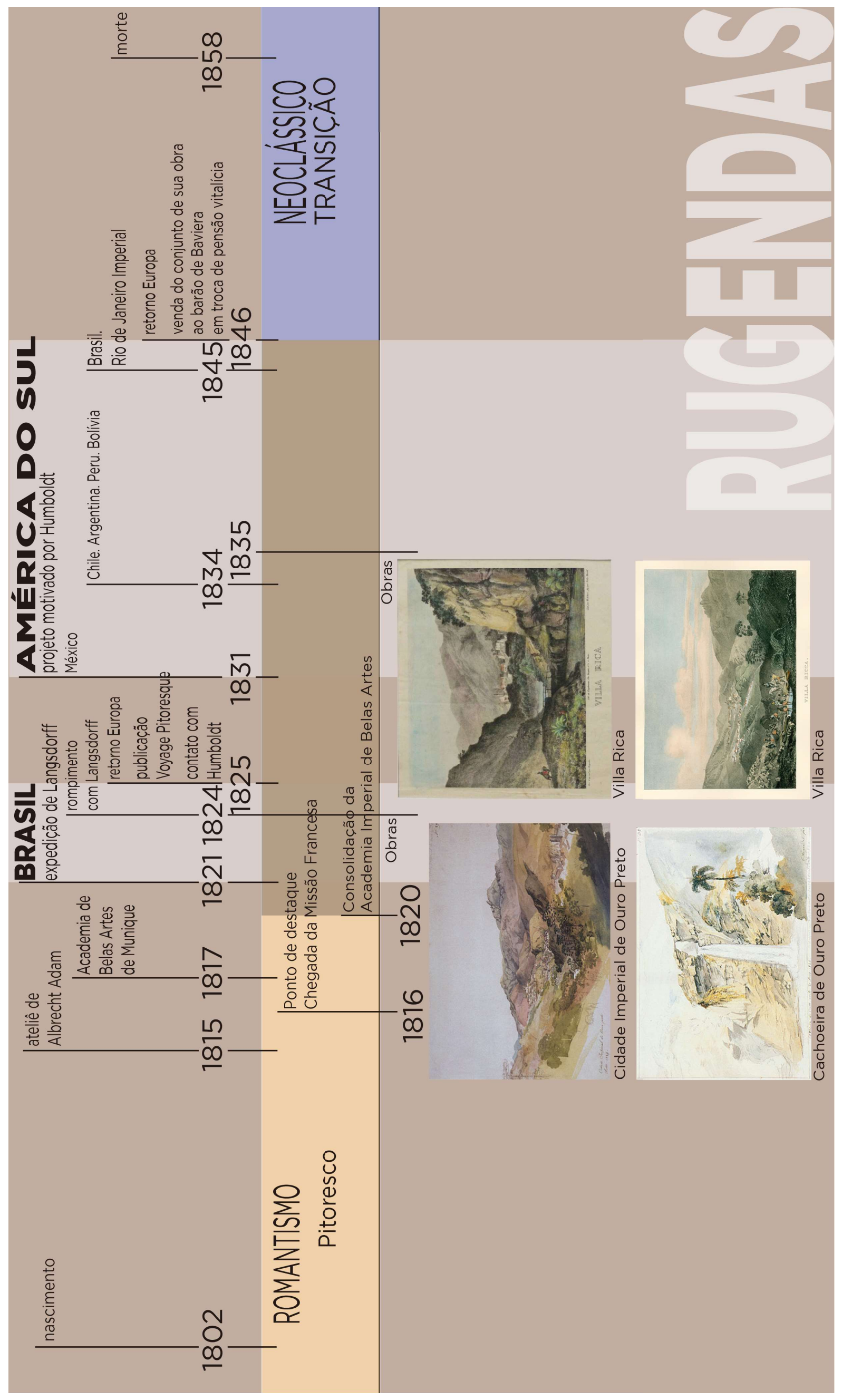




\section{Um olhar sobre Rugendas}

[2] Esses desenhos foram adquiridos pelo colecionador brasileiro José Mindlin e fazem parte de um estudo de Pablo Diener e Maria de Fátima Costa.

[3] Apenas a conhecimento, a segunda parte do livro está destinada aos tipos e costumes, a terceira, a uma mescla que inclui usos e costumes dos índios e a vida dos europeus e a quarta, aos usos e costumes dos negros.
[Quadro 2] Linha do tempo elaborada pela autora, 2017. Página ao lado.
Parte-se aqui da comparação dos desenhos produzidos por Rugendas durante sua primeira viagem ao Brasi ${ }^{[2]} \mathrm{com}$ as litografias feitas posteriormente para a publicação do Voyage Pittoresque dans le Brésil. Como um meio de compreender a paisagem forjada por Rugendas a partir da estética do pitoresco, esse estudo busca analisar algumas representações pictóricas e notar o quanto de um desenho produzido durante a viagem foi incorporado na produção das litografias, mostrando as aproximações e os distanciamentos da experiência adquirida no lugar com a representação consagrada no livro, ou seja, a paisagem vendida sobre o Brasil.

A escolha dos desenhos se pautou na primeira dentre as quatro divisões ${ }^{[3]}$ do Voyage Pittoresque dans le Brésil, cujo tema é paisagem, principalmente do Rio de Janeiro e de Minas Gerais. Um primeiro ponto a observar vem de uma recorrência nos desenhos de Rugendas. Estes captam a morfologia do lugar observado, assim como a vegetação típica e a presença, em alguns casos, da arquitetura; no entanto, o artista não se preocupa em preencher todo o campo do papel, preenchendo apenas o interior e deixando a extremidade inferior e superior em branco. Isso mostra que se atenta ao que está ao longe e ao que conforma a paisagem como aquela em si. Já as litografias que parecem ter sido produzidas desses desenhos se preocupam em preencher essas ausências, principalmente qualificando a extremidade inferior, por meio de uma cena específica. Nela, acrescenta tipos humanos participantes de uma ação e compõe essa cena com variados tipos de vegetação, dando peso, proximidade e entretenimento não só para a cena criada, como também para a composição total da obra, o que as tornam propícias a serem publicadas: maior atratividade ao público. A escolha tanto dos tipos humanos como da vegetação não são aleatórias ou inventadas, são baseadas nos estudos isolados feitos por Rugendas - vale lembrar aqui que durante sua estadia no país, o artista produziu diversos desenhos com viés naturalista e se atentou em captar as diferenças da fauna e flora dos trópicos, bem como dos tipos sociais tão distintos do europeu.

Ao relacionar os desenhos com as litografias, é possível ver a enorme semelhança entre um estudo de uma árvore e como ela aparece, não só em uma litografia, como em várias, mostrando justamente a característica vegetal de certa região do país. Quando as imagens são de paisagens de Minas Gerais, a recorrência se dá na presença de araucárias, já quando são de alguma vista do Rio de Janeiro, são as palmeiras que entram em cena. As composições das litogravuras parecem ser um jogo de colagem, em que os elementos se ajustam para compor uma paisagem que possa ser reconhecida por sua caracterização regional.

Os desenhos do artista-viajante parecem estar prontos para serem preenchidos. Ao deixar grande parte do campo plástico vazio, abre possibilidade para se preencher da maneira que quiser. É certo que Rugendas, ao participar, inicialmente, do processo de edição do Voyage Pittoresque dans le Brésil, compôs uma série de esboços baseados nos seus próprios estudos para se transformarem em litografias; no entanto, não se pode dizer de quantas composições ele participou e o quanto de habilidade e gosto do litógrafo entrou na produção final. Nos próprios desenhos pode se ver uma intenção do que virá a aparecer, um traço que esboça a existência de uma árvore em determinado lugar, de um arbusto em outro, mas mesmo assim, ao observar a litografia vê-se que há uma composição vegetal muito mais complexa que a própria intenção. Por outro 
lado, não dá para afirmar que o traço no qual simula uma árvore esteja representando, de fato, uma árvore específica, naquele lugar específico, pois como se sabe a escolha e a adaptação dos elementos presentes na realidade, dentro do modelo de apreciação do pitoresco, se dão para melhor harmonizar a representação, os elementos na natureza nunca estão perfeitos para a composição harmônica, é preciso adaptá-los para tal. Esse é um caso que está claramente presente em todas as litografias aqui citadas. Ao estarem vazias as extremidades dos desenhos, o litógrafo as preenche de modo a construir uma imagem harmônica, onde as árvores, os arbustos, as gramíneas e as pedras se rearranjam para serem atrativas aos olhos. Em geral, a obra possui elementos de destaque nas duas laterais e estes configuram a paisagem ao fundo, ora sendo árvores, ora palmeiras, ora rochas.

Quando os desenhos estão preenchidos na parte inferior possuem já uma cena, com uma ação humana e vegetação específica, o que se vê nas litografias é um afastamento da paisagem, um distanciamento do observador frente ao observado. Isso se caracteriza por basicamente três pontos: proporção do campo plástico - a litografia tem proporções mais suaves que a folha dos desenhos -; abaixamento da linha do horizonte, dando a ver mais céu e tamanho dos tipos humanos e dos animais, consequentemente posicionando o observador não só mais distante, como num ponto de vista mais alto que a cena em ação. A preocupação com o ponto de vista é uma característica bastante marcada na estética do pitoresco. A posição do observador, assim como o rearranjo da natureza contribuíam para criar uma paisagem mais amena e agradável. Esta era uma premissa do pitoresco, distanciando o observador da cena, este deixa de participar da situação, de ter uma relação mais próxima com o que lhe aparece, amenizando assim qualquer tensão que possa ser notada. De um modo geral, as imagens pitorescas nos mostram um lugar idealizado, no caso, as terras desconhecidas aproximadas da ideia de paraíso. Uma visão que se aproxima mais de um discurso de construção histórica do que da experiência do lugar, da própria relação do artista com o mundo a sua frente.

Após breve análise das representações pictóricas de Rugendas, tendo em vista a relação entre o que foi produzido, de fato, pelo artista-viajante durante seu período de estada no Brasil e o que veio a ser produzido como litografias para publicação, no livro Voyage Pittoresque dans le Brésil, foi possível perceber o quanto as imagens que foram difundidas do Brasil são idealizadas e quanto não seguem aquilo que foi observado in loco pelo artista. E mais, a grande ideia que essa publicação passou foi, ao mesmo tempo, de ter sido obra executada por Rugendas e ter sido aquilo que experimentou aqui no Brasil. Questões que foram possíveis após perceber algumas recorrências, assimilar os elementos estruturadores tanto do desenho quando da litografia e associar informações após uma visão geral de toda a obra disponível nos estudos de Pablo Diener e Maria de Fátima Costa (2002).

O modo de apreciação em que se pautavam os artistas europeus buscava, mais do que se apropriar da experiência do lugar, seguir um conjunto de regras para se construir um discurso, se construir uma paisagem, que com finalidade de agradar ao público acabam por manter próxima a ideia do Brasil como lugar do paraíso.

Nesse sentido, a produção artística dos artistas-viajantes, aqui exemplificada
[Figura 1] Estudo de uma palmeira, 1822 a 1825 e Playa Rodriguez, 1835.

[Fonte] DIENER; COSTA 1998 e DIENER; COSTA, 2002. Página ao lado.

[Figura 2] Estudos de araucárias, 1824 e Serra Ouro-Branco, 1835.

[Fonte] DIENER; COSTA, 1998 e DIENER; COSTA, 2002. Página ao lado.

[Figura 3] Vista da fazenda Mandioca, 1822 a 1825 e Mandiocca, 1835. [Fonte] DIENER; COSTA, 2002. Página ao lado. 

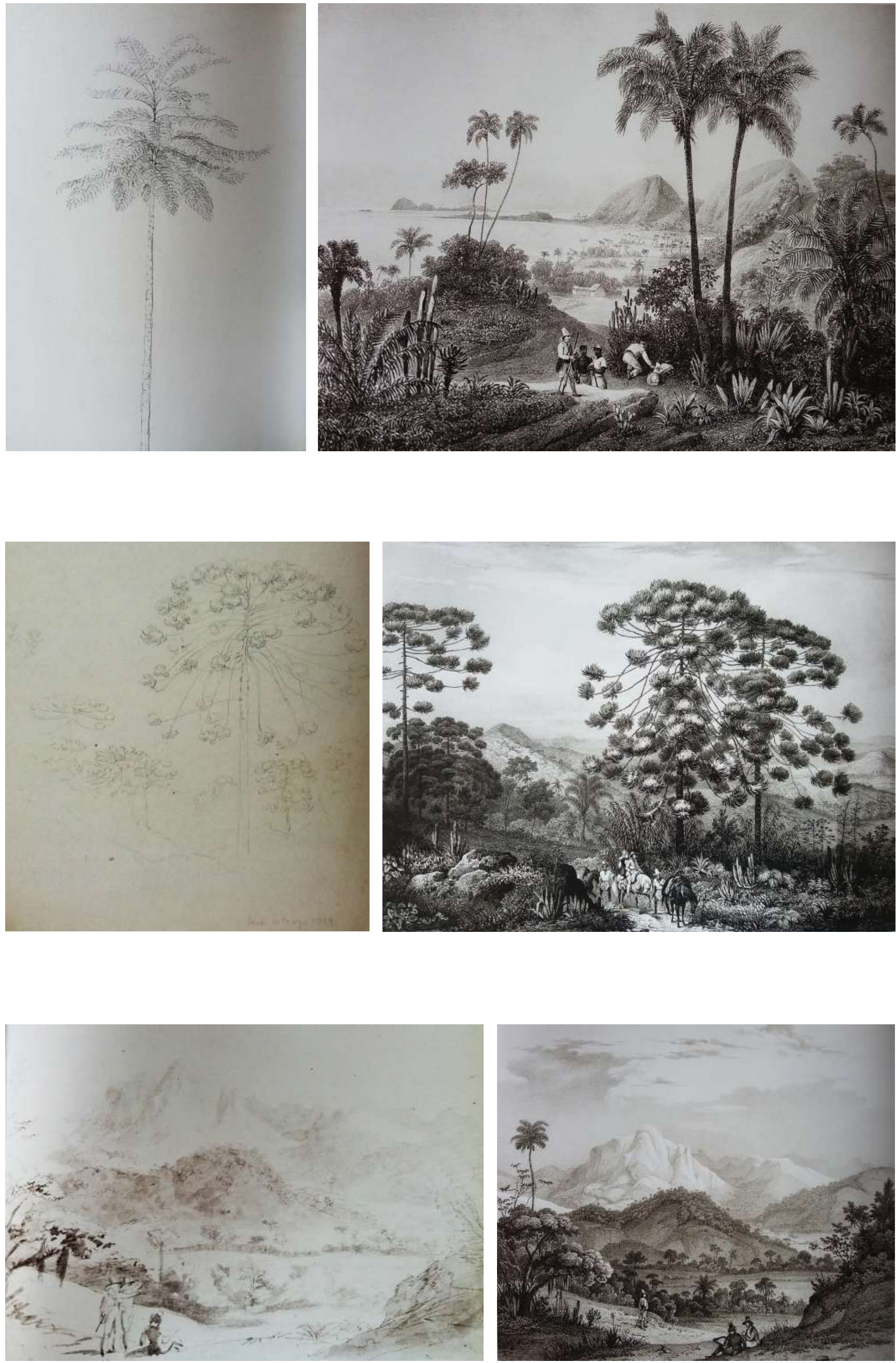
pela figura de Rugendas, pode ser vista como um contra-exemplo quando se pensa sob o viés merleau-pontyano, estruturador da presente pesquisa. Para Merleau-Ponty, é necessário experienciar o lugar, ter contato com o mundo percebido, o mundo em sua essência. É no próprio ato de pintar o artista se abstrai dos juízos e valores do mundo em que vive para se abrir ao mundo percebido, isso por meio do seu corpo, que é quem possibilita a percepção. O que aparecerá no quadro é a própria percepção de quem se expressa, adquirida conforme sua experiência vivida em um determinado contexto histórico. E nesse caso, Rugendas, representante dos artistasviajantes, não representava simplesmente o que via, o que experimentava, não se desligava dos juízos e valores desse mundo e se baseava em um conjunto de regras que advinham de um modelo de apreciação europeu, o pitoresco, para, juntamente com os litógrafos, construir a imagem de um Brasil que o período histórico tinha interesse em apreciar.
[Figura 4] Vista da baía de Guanabara, RJ, 1822 e Vue de Rio de Janeiro, 1835.

[Fonte] DIENER; COSTA, 2002.
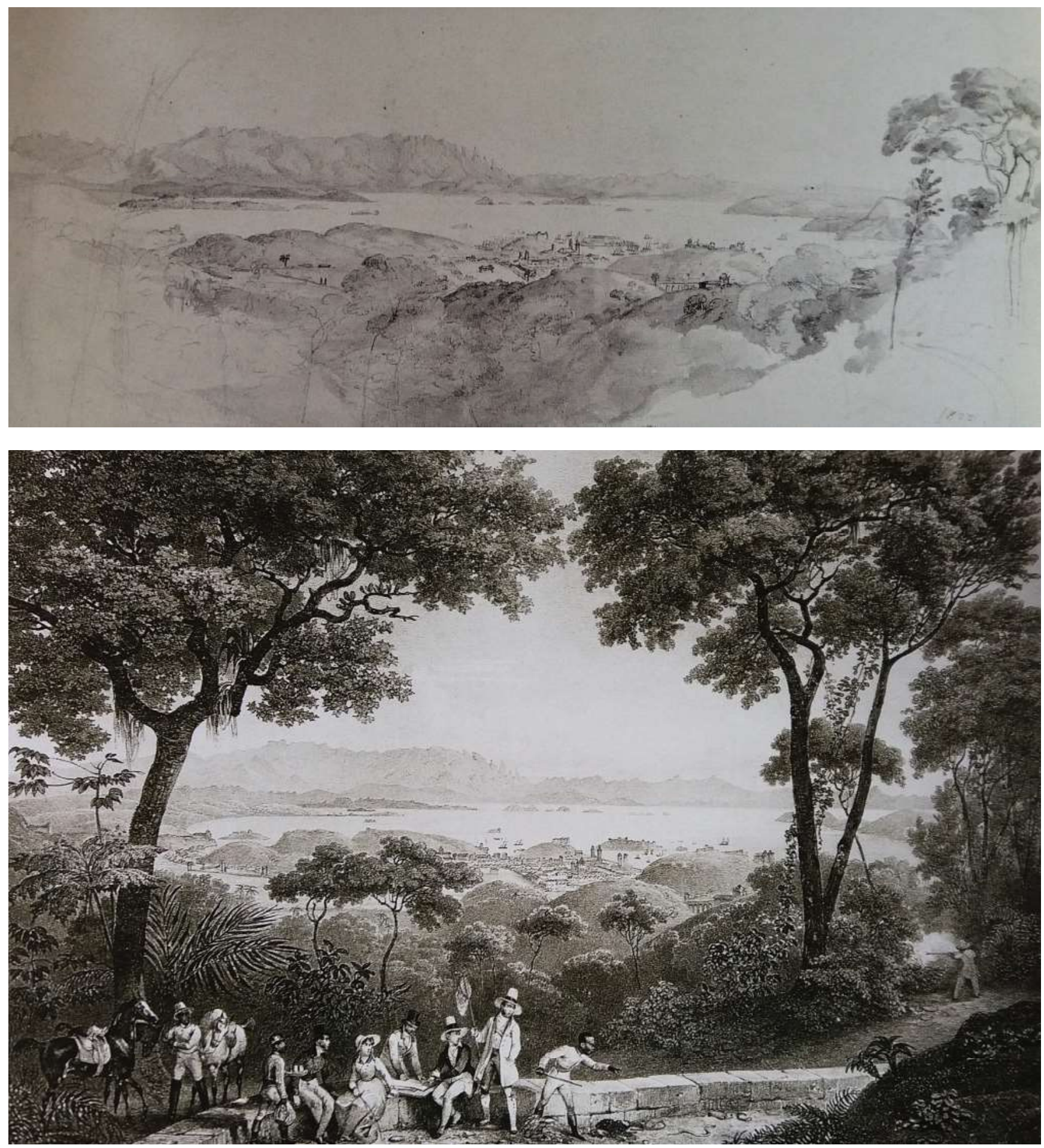


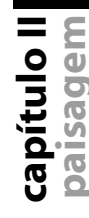




\section{capítulo III lugar}


As primeiras ocupações do território mineiro serão o início para a compreensão do que veio a ser a expansão urbana de Ouro Preto, entendendo como essa cidade se consolidou posteriormente e quais foram suas sucessivas fases de desenvolvimento, desde a origem com a fundação dos primeiros arraiais até o presente século, nos anos 2000.

O processo evolutivo da cidade foi marcado por três períodos relevantes, o primeiro que tem início no final do século XVII, com a formação de Vila Rica, em um percurso que vai do auge da mineração até seu declínio com o esgotamento das jazidas de ouro nas primeiras décadas do século XIX. O segundo, desde essa fase de declínio até a última década do século XIX, com a mudança da capital para Belo Horizonte. E o terceiro, que percorre o século $X X$ até chegar ao século $X X I$, uma fase marcada por outro processo de declínio e, posteriormente, de expansão da cidade.

Ouro Preto teve um percurso muito peculiar, devido a morfologia do relevo em que está inserida. A topografia acidentada foi determinante para a forma de ocupação da cidade. Sobre essa questão, Sylvio de Vasconcellos (1977, p. 66) afirma no seu estudo sobre Vila Rica que a topografia é bastante imprópria ao estabelecimento de uma povoação e que os terrenos planos naturais são praticamente inexistentes, sendo a sua obtenção, por aterros ou cortes, dificultada pela dureza do solo.

A cidade se construiu a partir de um grande eixo leste-oeste, aproveitando a orientação do relevo. Enquanto que as ocupações mais recentes, expandiram-se no sentido norte-sul, apropriando-se das encostas com alta declividade.

A evolução de Ouro Preto foi marcada por fases de expansão e fases de declínio, as quais consolidaram o território que se conhece atualmente. Ao abordá-las, busca-se compreender o processo que envolve a construção dessa cidade e qual relação estabelece com as paisagens de Guignard. 


\section{Formação de Vila Rica [1695] à elevação a Ouro Preto [1823]}

\section{Desenvolvimento Urbano}

A cidade de Ouro Preto tem origem com as descobertas auríferas e remonta ao final do século XVII. Após a disseminação da fama do local e novas descobertas, há um grande crescimento de várias localidades, ou seja, novos arraiais se formam e começam a surgir pequenos tipos de comércios e assentamentos provisórios organizados ao redor de uma capela. Inicia-se, assim, vários núcleos urbanos que se estruturam ao longo de uma estrada principal, denominada caminho-tronco. Em 1711, os núcleos existentes, como Ouro Preto, Antônio Dias e Padre Faria, ao se desenvolverem, unemse e dão origem a Vila Rica.

Nesse sentido, vale lembrar que a criação legal da Vila também

Revela a intenção da Coroa de demarcar e fiscalizar todo o território da capitania, instalando funcionários do governo, impondo a ordem e a justiça, assim como a cobrança de tributos, reforçando o desenvolvimento de um processo intenso de civilidade. (SALGADO, 2010, p. 49)

A partir de 1713, a Câmara Municipal, cuja preocupação com a regulamentação do espaço urbano, com a cobrança de impostos e com a regularidade das ruas ou espaços públicos, estabelece normas e restrições para a inserção do comércio na Vila. Tal acontecimento pode ser considerado o primeiro zoneamento urbano em Vila Rica. (VIEIRA, 2016, p. 63). O zoneamento foi facilitado pela existência dos arraiais desde a concepção da Vila, cada um com administração e igreja próprias.

Junto a isso ocorre uma mudança quanto à forma urbana, alterando o caráter primitivo das edificações. "Com a consolidação da Vila, novos materiais, mais resistentes e duradouros, foram introduzidos." (VIEIRA, 2016, p. 61).

Com o sucesso da atividade mineradora, a região passa por um intenso processo de expansão urbana, principalmente entre as décadas de $1730 \mathrm{e}$ 1760. Além das mudanças nas edificações, altera-se a estrutura urbana em geral. Em 1740, quando Gomes Freire de Andrade governa a Vila,

\footnotetext{
Inicia-se um surto extraordinário de progresso. As primitivas pontes de madeira são substituídas por outras de pedra sobre arcos romanos. Inúmeros chafarizes públicos oferecem suas águas aos habitantes. As ruas são calçadas, e canalizações hidráulicas instaladas. A vila adquire aspectos de cidade, quase metrópole. (LEFEVRĖ; VASCONCELLOS, 1968, p. 26)
}

E ainda nesse governo, estabelece-se a praça principal que une os principais arraiais, Antonio Dias e Pilar, ao criar nela o centro administrativo com a implantação do Palácio-Fortaleza próximo à antiga Casa de Câmara. (SALGADO, 2010, p. 63)

Entretanto, ainda nos anos 1760 a situação se complica e a atividade aurífera decaí sobremaneira. A população dirige-se para outras áreas 
após o esgotamento das minas e o final do século XVIII é marcado por um processo de retração demográfica e, também, econômica. Vila Rica deixa de ser o centro de referência econômica no país, mas mesmo assim, em 1823, eleva-se a capital da Província de Minas Gerais, passando a ser chamada de Ouro Preto, ponto de partida para a segunda fase desse estudo.

\section{Implantação urbana}

Como já dito, Vila Rica se formou a partir de um eixo leste-oeste, localizado nas cotas mais baixas da Serra de Ouro Preto, chamado de caminhotronco. Essa conformação longitudinal se deve à ocupação dos primeiros arraiais. O caminho começa

No Passa-dez, sobe para as Cabeças. Desce para o Rosário e Matriz de N. S. do Pilar, para elevar-se de novo até o Morro de S. Quitéria, onde está a praça urbana principal. De novo mergulha para Antonio Dias, e sobre para o Alto da Cruz. Escorrega finalmente para o antigo Arraial do Padre Faria, e inflete para a cidade de Mariana. (LEFEVRĖ; VASCONCELLOS, 1968, p. 28)

O caminho-tronco não era a única estrada que configurava Vila Rica, havia também outras menores, como a que ligava à São Sebastião e à São João, em direção à Serra de Ouro Preto.

Assim como o eixo principal, determinado pela morfologia do relevo e determinante para o desenvolvimento da malha urbana, a construção das igrejas também desencadeou um papel fundamental, pois mais do que serem pontos de referência na paisagem, acabaram por direcionar o crescimento da cidade.

Vasconcellos (1977) explica o desenvolvimento de Vila Rica inicialmente ao longo desse eixo longitudinal e posteriormente em dois momentos. $\mathrm{O}$ primeiro, na primeira metade do século XVIII, sendo um movimento centrípeto em direção ao Morro de S. Quitéria, onde se localizava a praça principal, hoje conhecida como Praça Tiradentes. "Com a delimitação do centro administrativo, estabelece-se o núcleo principal da povoação." (VASCONCELLOS, 1977, p. 77)

E o segundo, a partir da segunda metade do século XVIII e início do XIX, um movimento centrífugo em direção contrária a existente, para as extremidades da Vila. Ao mesmo tempo que reforça a linearidade do caminhotronco, cria novos arruamentos. "Ramificam-se as saídas e desdobram-se os arruamentos paralelos ao principal, ligados, geralmente, por simples serventias de passagem, travessas, vielas ou becos" (VASCONCELLOS, 1977 , p. 79), com isso os fundos de lote se transformam em testadas ao ter que se subdividirem e criam uma nova configuração para a malha urbana.

Ainda na década de 1710, logo que as edificações passaram de provisórias para definitivas, pode-se ver a evolução da tipologia residencial na Vila:

As exigências com relação às moradias se modificam, principalmente devido ao aumento da população que iria demandar consequentemente a necessidade de residências maiores, com maior número de cômodos; assim, a casa térrea tende a se expandir e este movimento ocorre horizontalmente. Estas vão se diferenciar das primeiras
[Figura 5] Configuração dos primeiros arraias em Ouro Preto.

[Fonte] Croqui elaborado pela autora com base em VASCONCELLOS, 1977, p. 72. Página ao lado.

[Figura 6] Crescimento centrípeto de Ouro Preto.

[Fonte] Croqui elaborado pela autora com base em VASCONCELLOS, 1977, p. 78. Página ao lado.

[Figura 7] Crescimento centrífugo de Ouro Preto. [Fonte] Croqui elaborado pela autora com base em VASCONCELLOS, 1977, p. 80. Página ao lado. 

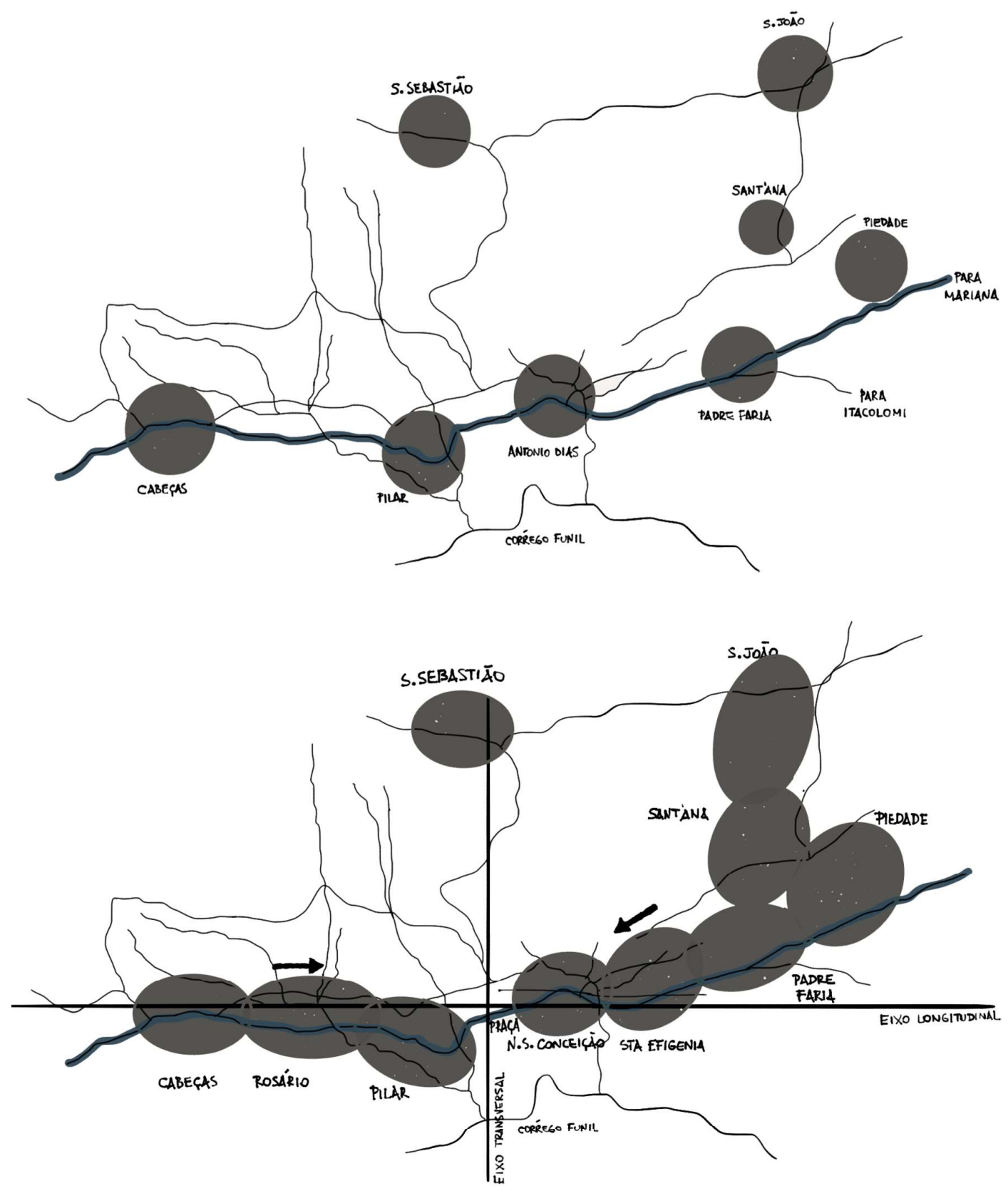

$\frac{\overline{0}}{\frac{0}{3}}$

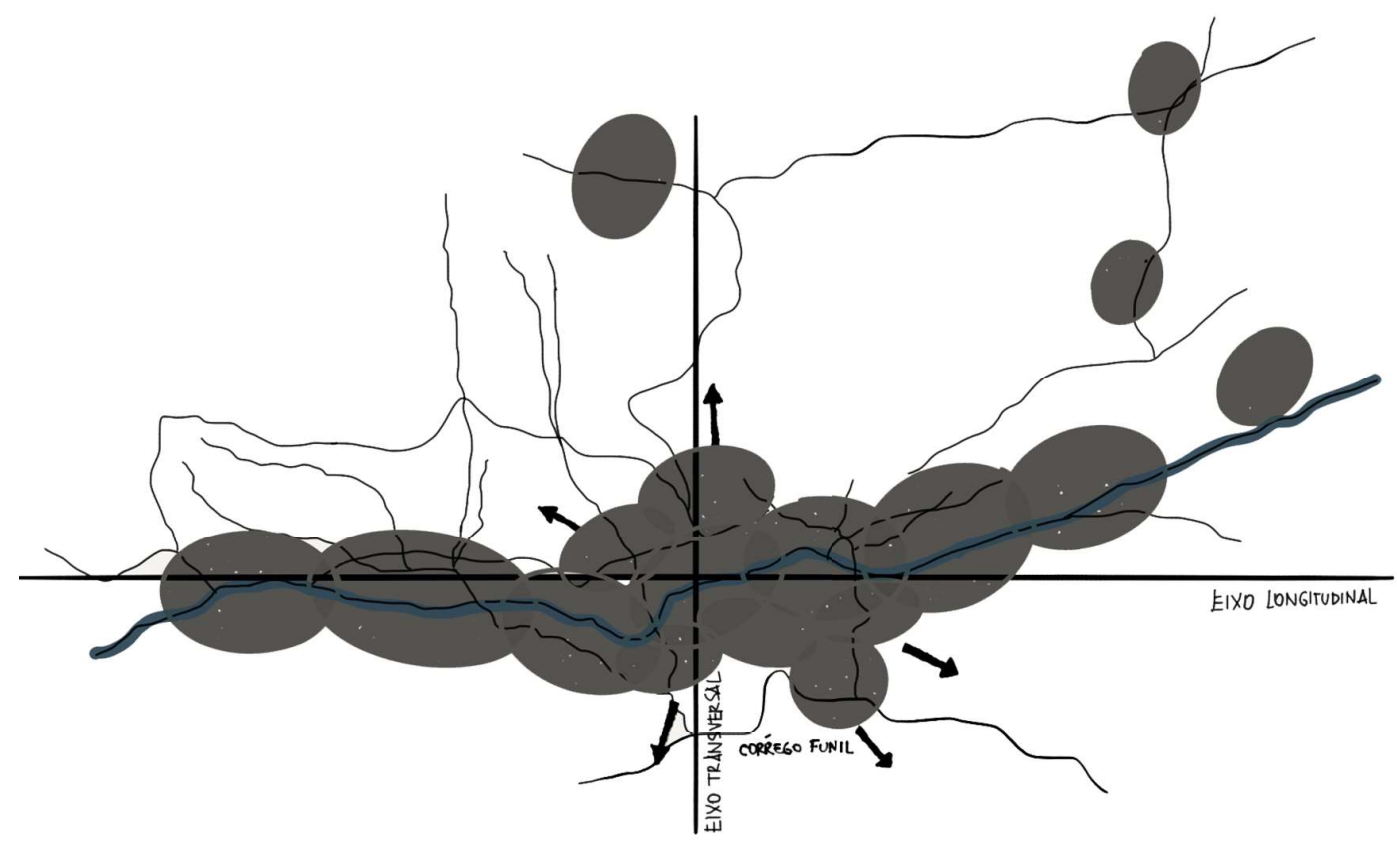


Essa característica de horizontalidade tende a diminuir, devido à escassez de lotes no centro da Vila. Com isso, há um aproveitamento melhor dos arruamentos e as edificações se invertem, passando a ter o menor lado voltado para a rua e alongando-se na direção dos fundos de lote, o que possibilita a existência dos quintais. Aqui a tipologia mais comum é a casa térrea com um grande corredor que conecta a entrada principal ao quintal. (SALGADO, 2010, p. 71)

A expansão da Vila e o desenvolvimento comercial proporcionou uma outra alteração na tipologia residencial. Não tendo mais espaço disponível para o crescimento horizontal da área central, origina-se o sobrado. De início, o sobrado contava apenas com uso residencial, depois passa a abrigar o uso comercial no primeiro pavimento. (SALGADO, 2010, p. 72)

Como estrutura típica da Vila após a evolução mostrada, é possível perceber que se dispõem ao longo do caminho-tronco: possuem um desenho bem definido e os lotes, de largura estreita, faceiam tanto a rua quanto os lotes imediatamente próximos, ou seja, não há recuo frontal nem lateral. Embora os lotes sejam estreitos, ganham tamanho em profundidade, uma vez que não há limite posterior estabelecido, esses limites são as próprias barreiras geográficas, por exemplo, córrego ou base de morro.

Nestor Goulart Reis Filho (1970, p. 22) afirma a questão enquanto característica do lote urbano colonial, "as vilas e cidades apresentavam ruas de aspecto uniforme, com casas térreas e sobrados construídos sobre o alinhamento das vias públicas e sobre os limites laterais dos terrenos".

Nesse período as ruas não eram arborizadas, nem existiam jardins públicos, a massa arbórea se constituía pelos fundos de lote com os quintais. Com isso, fica mais evidente a definição dos lotes no alinhamento da via, corroborada ainda com a semelhança entre as edificações como, por exemplo, no tipo de telhado,

O sistema de cobertura, em telhado de duas águas, procurava lançar uma parte da chuva recebida sobre a rua e a outra sobre o quintal, cuja extensão garantia, de modo geral, a sua absorção pelo terreno. (REIS FILHO, 1970, p. 26)

Essas características que mostram certa regularidade do espaço urbano, no período colonial, advêm de um processo de regulamentação feito pela Câmara, para atender aos interesses da Coroa, ainda no início da formação da Vila. As edificações implantadas de forma ordenada, alinhadas a via e com aparências semelhantes, salvo algumas exceções; o cuidado com o arruamento, geralmente com a mesma largura; as igrejas assentadas em posição de destaque, marcando os pontos altos da cidade, tudo convergindo para uma morfologia urbana ordenada que será o primeiro passo para entender, posteriormente, o processo de preservação e patrimonialização de Ouro Preto. Deixando evidente que a preocupação com a aparência da cidade sempre esteve presente, desde a sua primeira conformação.

Mas vale reforçar que após o declínio da atividade mineradora, a cidade entra em um período de retração econômica e demográfica. $E$ as questões que, de certa maneira, envolviam o desenvolvimento urbano foram deixadas de lado. Esse desapreço contribuiu para alterar a aparência da Vila. 


\section{Elevação a Ouro Preto [1823] à mudança da capital para Belo Hori-} zonte [1897]

\section{Desenvolvimento urbano}

A situação de Ouro Preto, no início do século XIX, gerava um cenário decadente por conta do esgotamento das jazidas de ouro e pela perda de grande parte da população. Como consequência, o abandono das casas agravou o quadro da cidade e o que se encontrava nela era um conjunto mal conservado, embora não tão agravado devido ao status de capital. "O título de capital da província de Minas Gerais será a principal função desempenhada pela cidade neste período, o que já Ihe havia rendido muita riqueza anteriormente". (SALGADO, 2010, p. 79)

Por mais que o final do século XVIII tenha sido de retração demográfica parte da população continuou na cidade, deixando-a ativa de uma outra maneira. "O século XIX foi marcado por um crescimento vegetativo positivo da população livre, uma vez que Vila Rica manteve-se como capital da província e a cidade encontrou outra dinâmica". (VIEIRA, 2016, p. 144)

O crescimento vegetativo, mesmo sendo positivo, pode ser considerado como um período de estagnação, uma vez que quase não houve crescimento, embora mais para o final do século tenha se expandido mais. Nesse período, as atividades econômicas que alimentavam Ouro Preto eram o comércio e o artesanato. Além disso, dava-se início a uma formação educacional constituída por um colégio para educação das meninas em 1828, pela Escola de Farmácia e Bioquímica em 1839, pela Escola Normal em 1873 e pela Escola de Minas, em 1876.

\footnotetext{
Estas instituições de ensino serviram de estímulo ao desenvolvimento da cidade, podendo este ser demonstrado pelos dados de população que, em 1818, era de 12.000 habitantes, em 1878 de 13.000 e, em 1890, de 17.860. (SALGADO, 2010, p. 80)
}

Como se pode ver, algumas medidas foram implantadas em Ouro Preto para tentar amenizar essa fase de declínio e decadência. Foram elas que conseguiram mantê-la ainda com um leve crescimento positivo, não a deixando morrer.

Além das medidas já citadas, foi proposta uma outra, o plano de melhoramentos de 1891. O plano se baseava em uma intervenção urbana, como tentativa de segurar a capital em Ouro Preto. No entanto, a intervenção tinha fundamentos voltados para a modernização das cidades, com mudanças drásticas no território urbano, como cortes de morros, ampliação e retificação das vias, construção de edificações modernas, soluções que não condiziam com a morfologia de cidade em questão.

No caso do plano de melhoramentos de Ouro Preto, não se pode falar de uma política urbana de conjunto, somente de renovação de certos quarteirões e da construção de alguns equipamentos modernos com a finalidade de colocar a cidade na "via do progresso". (SALGUEIRO, 1996, p. 131) 
A proposta não se consolidou, tanto por falta de recursos financeiros quanto de recursos técnicos. A nova cidade criada por esse plano não surgiria de uma conjunção com a antiga, mas sim de uma imposição que acabaria com a memória existente. Além dos empecilhos citados, o plano não se concretizaria, "porque a ideia de construir uma cidade nova noutro lugar era agora irreversível”. (SALGUEIRO, 1996, p. 134)

Diversas críticas surgem diante desse cenário de Ouro Preto e a cidade escolhida para receber o posto de capital é Belo Horizonte, fato que ocorreu em 1897. Como aponta Arley Andriolo, "tal data sintetiza as posições relativas ao século XIX e sobre a situação de desprestígio que envolvia Ouro Preto". E mais, "a mudança da capital também era regida por um sentido estético, pelo qual as construções coloniais tornaram-se indignas de abrigar os poderes provinciais". (ANDRIOLO, 1999, p. 17)

Belo Horizonte, planejada aos moldes da modernidade, seria então o símbolo da República, sendo que Ouro Preto era vista como o contrário. Conforme explica Heliana Angotti Salgueiro (1996, p. 131),

a decisão oficial de mudar a capital de Minas Gerais figura na Constituição Republicana de 1891 e reforça a crítica da falta de condições oferecidas por Ouro Preto para tornar-se uma capital moderna.

Como já dito, avenidas largas e grande planejamento urbano eram justamente características inviáveis para uma cidade como Ouro Preto, marcada por sua topografia acidentada e, consequentemente, por sua conformação urbana. "Era o símbolo de um tipo de formação urbana que deveria ser radicalmente alterado por estar associado ao atraso e à insalubridade". (AGUIAR, 2013, p. 180)

A mudança da capital ocasionou graves problemas em Ouro Preto, principalmente pelo forte êxodo populacional. Abandono não só por parte da população em si, mas abandono político e administrativo, deixando-a mais decadente do que já estava mesmo antes dessa alteração. Foi uma fase de obscurantismo, na qual a cidade estaria fadada ao esquecimento.

Implantação urbana

O processo de regulamentação de Ouro Preto, iniciado pela atuação da Câmara na fase anterior, estende-se ainda mais e em 1830 são postas em ação as Posturas da Câmara, que representariam as leis e normas seguidas para regular a cidade. "As Posturas de 1830 inserem a preocupação com a fisionomia da cidade através da regulamentação dos alinhamentos das edificações". (SALGADO, 2010, p. 84)

Como é sabido, esse período não é marcado pela forte expansão urbana, no entanto ocorreram algumas alterações que marcaram a estrutura de Ouro Preto. Com relação à forma urbana, houve uma expansão na malha viária, mesmo porque a área central está ainda mais adensada e nas imediações da Praça, nota-se a formação de quadras mais definidas. É aqui que entra o movimento centrífugo da expansão da cidade citada anteriormente, onde aparecem arruamentos novos e os lotes, ao se dividirem, transformam em testada o que era fundo. Além disso, surgem caminhos próximos aos edifícios religiosos, marcado também por um maior adensamento nos bairros.

74 Uma via de extrema importância é a paralela ao caminho tronco, ao norte. 
À medida que se estabelece mais um eixo longitudinal que coincide com o primeiro vetor de expansão, além do caminho tronco, iniciase a formação de vias de ligação entre os dois, o que ocorre significativamente na porção oeste da cidade, além de possibilitar a ocupação das áreas internas aos dois grandes caminhos. (SALGADO, 2010, p. 87)

Outra questão que proporcionou a expansão urbana em Ouro Preto foi a implantação da linha férrea, em 1888, a qual seguia o leito do Ribeirão Funil, na região sul da cidade. Próximo a ela, surgem algumas vias com ocupações esparsas, constituindo uma área pouco adensada.

Apesar do acesso às novas técnicas construtivas proporcionado pela chegada da ferrovia,

Nas Minas, as inovações não eclipsaram de todo a tradição, tanto por motivo de estar a região mais afastada dos centros de irradiação das novas doutrinas, como também, porque, já por esta época, uma pronunciada decadência econômica não permitiria de fato consideráveis desenvolvimentos ou alterações profundas na grande maioria de suas povoações. (VASCONCELLOS, 1977, p. 195)

[Figura 8] Vias principais e eixos de expansão de Ouro Preto.

[Fonte] Croqui elaborado pela autora com base em SALGADO, 2010, p. 88.
Sylvio de Vasconcellos (1977, p. 197) acrescenta que as intervenções foram mínimas, alterando, no máximo, elementos mais decorativos, caixilhos caprichosos, pinturas inadequadas, esquadrias de venezianas, meiosportões de ferro ou modilhões sob as sacadas, mascarando as fachadas com uma maquiagem moderna. Cabe ressaltar que essas pequenas alterações ocorreram nas edificações localizadas ao longo do caminho tronco, não se desdobrando para as outras regiões.

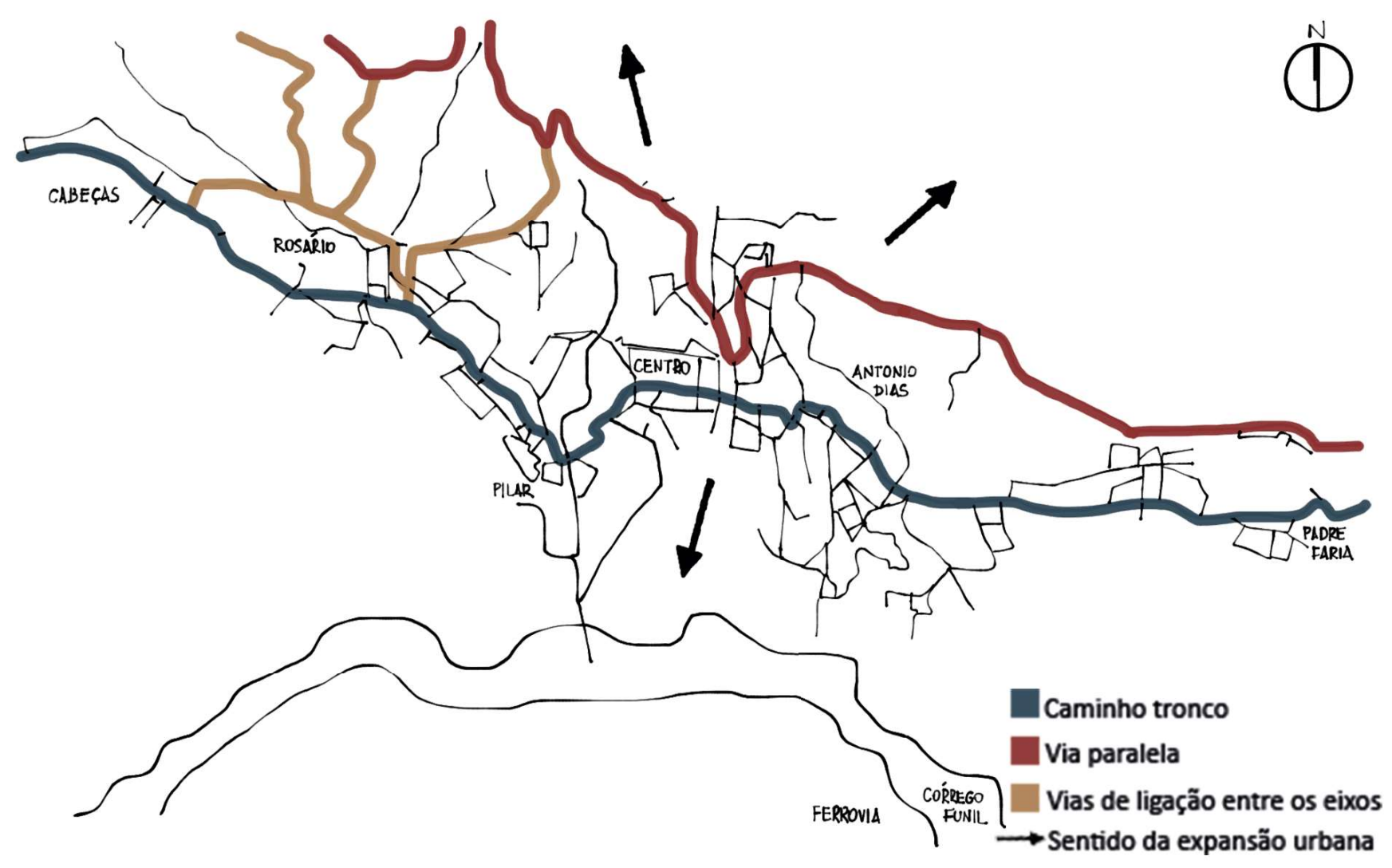


Com relação as novas edificações,

Apenas a partir da segunda metade do século XIX é que se verifica o aparecimento de residências urbanas com nova implantação, 'deslocadas' dos limites no lote e em um esforço na conquista e incorporação do espaço externo à arquitetura das residências, através de jardins. (VIEIRA, 2016, p. 183)

Mesmo com essas alterações, o que se percebe é uma mudança relativamente pequena, apenas no que diz respeito à relação da arquitetura com o lote, alterando a dimensão e não o tipo. Mudanças mais drásticas ocorrerão no século $\mathrm{XX}$, como se verá na próxima fase.

Como síntese dessa fase, há dois acontecimentos políticos que refletem a configuração urbana de Ouro Preto, a instauração do Império, com a Independência do Brasil, em 1822 e a Proclamação da República, em 1889.

As cidades do Império, de maneira geral, não seguem o caráter urbanístico do período colonial. Toda a preocupação que a Coroa de Portugal tinha com as ações relativas a estrutura urbana, o governo imperial descarta alegando ser um desperdício de capital investir no desenvolvimento da cidade. O investimento era feito no setor rural e no comércio de escravos. Sendo assim, a cidade no século XIX sofria com condições sanitárias trágicas e em Ouro Preto não era diferente. Com a chegada da República, esse quadro é revertido e logo no início do século $X X$ já aparecem obras de melhoramentos urbanos. (VIEIRA, 2016)

Entretanto, é possível perceber que a expansão urbana de Ouro Preto seguiu o traçado do século anterior, sendo as exceções citadas aqui, diluídas na conformação da cidade. E como se verá, no início do século XX, as modificações pontuais feitas no século XIX terão que ser adequadas ao estilo colonial.

Decadência e Expansão [fase 3]

\section{Da mudança da capital para Belo Horizonte [1897] à configuração atual}

\section{Desenvolvimento urbano}

Com a mudança da capital para Belo Horizonte, nas primeiras décadas do século XX, Ouro Preto foi marcada por uma fase de decadência política, econômica e demográfica. Essa condição começa a se transformar com o surgimento das discussões sobre preservação de uma memória, de uma cultura, de um Brasil em diversas esferas. Ouro Preto, assim sendo, passa a adquirir um papel de destaque por ser grande representante da história brasileira, atrelado a sua importância durante o período colonial.

Foi um processo lento de valorização da cidade e que se iniciou graças a uma parte da população que defendia do caráter antigo de Ouro Preto. Para tanto, a cidade não deveria entrar no processo de modernização sem se voltar para todo o passado que existiu, nem tão pouco, mudar sua condição material, mas deveria trazer as marcas de tal passado em seu traçado e em sua arquitetura.

Segundo Caion Meneguello Natal (2005, p. 6), 
Em fins do século XIX e começo do XX, Ouro Preto passa a assumir uma imagem cujo principal atributo seria sua imutabilidade como signo da preservação de uma memória histórica; de uma tradição que deveria ser mantida sob pena de perder um importante elemento constitutivo da identidade brasileira e mineira.

A cidade simbolizaria, então, uma identidade tanto mineira quanto brasileira por meio de seu passado presentificado, notado na sua arquitetura e no seu traçado urbano e, consequentemente, guardaria as peculiaridades de uma memória coletiva. A relação com seu passado se altera: o que era para ser esquecido passa a ser valorizado. A cidade deve contar sua história por meio das edificações, monumentos e ruas.

\begin{abstract}
Agora, ela não mais seria vista como uma cidade decadente, desordenada, decrépita ou vetusta, que deveria ser transformada, mas, ao contrário, torna-se a imagem de um passado heroico que deveria ser preservado da ação temporal. (NATAL, 2007, p. 6)
\end{abstract}

Alguns acontecimentos a respeito disso surgiram durante as primeiras décadas do século XX. Dentre eles, os projetos políticos criados a partir da formação do SPHAN, em 1937, em busca de elencar e salvaguardar os bens patrimoniais; os discursos e ações que contribuíram para a criação de uma cidade histórica, com visão de patrimônio nacional e a expedição modernista de 1924, conhecida como viagem de redescoberta do Brasil, feita a Minas Gerais, mais especificamente a Ouro Preto, cujo objetivo era "descobrir as origens da nacionalidade para se construir um país moderno". (HORTA, 2014, p. 114). Além disso, a viagem lançou base para uma política preservacionista de cunho oficial, possibilitando ampliar o sentido de cidade histórica.

A viagem dos paulistas para as cidades históricas mineiras será um paradigma de identidade. Motivada por esta visão de busca de uma identidade nacional, a expedição marcará substancialmente o movimento moderno. Os artistas têm explicações plausíveis para a escolha de Minas Gerais, segundo Mario de Andrade, uma arte original foi gerada em Minas devido ao isolamento e distância das cidades mineiras em relação ao litoral. Além da decadência das mineradoras que fez com que, de certa maneira, as cidades mineiras deixassem de ser tão influenciadas pela cultura portuguesa, possibilitando maior liberdade quanto à organização territorial e urbana, como será mostrado logo a seguir. A peculiaridade da arquitetura religiosa, intensamente marcada aqui, também pode estar relacionada a essa questão.

O Barroco mineiro representaria para o autor de Macunaíma, por seu estilo, a verdadeira expressão artística nacional, por não importar elementos externos em seu plano arquitetônico, incorporando a própria decoração. $O$ barroco mineiro seria, enfim, o primeiro estilo artístico da nacionalidade tupiniquim. (HORTA, 2014, p. 119)

A Viagem foi composta por artistas como Mario de Andrade, Oswald de Andrade e Tarsila do Amaral, os quais levaram o poeta suíço-francês Blaise Cendrars para conhecer um Brasil velado pelo progresso das capitais. Esta viagem foi de extrema importância, uma vez que representou a ascensão do enfoque nacionalista. Com isso, 
Um novo olhar para a arquitetura colonial se afirmava [...] Doravante, o legado artístico colonial passava a ser visto não como um estilo acabado, mas como produção híbrida, ou antes, popular, e a arquitetura barroca reinterpretada como universo aberto à intervenção de cristãos e pagãos, artistas e artesãos, europeus, ameríndios e africanos. (SODRÉ, 2010, p. 73)

A aproximação com realidades diversas daquelas encontradas na cidade de São Paulo, a possibilidade do contato com o outro, o próprio questionamento de suas esferas de pertencimento, enfim, tais deslocamentos apresentam um caráter fortemente etnográfico, restabelecendo novas fronteiras entre as esferas. (SODRÉ, 2010, p. 71)

João Clark de Abreu Sodré (2010, p. 71), ainda exemplifica por meio da obra de Mario de Andrade, que o modernismo brasileiro expresso na viagem modernista aparece a partir da busca pelas características brasileiras consideradas legítimas e associadas à ideia da recuperação de um passado e uma tradição, cujos vestígios se encontravam diluídos na cultura popular a partir da língua falada, da música e das artes plásticas.

O modernismo assumia a sua contradição essencial: na busca do novo, encontrava, através do velho, uma identidade genuinamente brasileira, encontrava uma tradição brasileira - no presente, o passado. À medida que o conjunto arquitetônico barroco era valorizado, a relação dos artistas brasileiros com o modelo europeu ia sendo revista. (FRANCO, 2013, p. 212)

"A preocupação com a preservação da arquitetura e das imagens coloniais levará o grupo a planejar uma forma de preservar o patrimônio mineiro". (FRANCO, 2013, p. 213). Essa forma se deu através da criação de um plano para a formação de uma Sociedade dos Amigos das Velhas Igrejas de Minas Gerais, cujo objetivo seria a preservação das igrejas abandonadas. Entretanto, o ideal de restabelecer a identidade brasileira a partir da valorização do passado artístico barroco se perdeu com a Revolução de 24. Uma década depois, reapareceu e passou a tomar dimensões oficiais, isto é, em 1933, a cidade de Ouro Preto foi declarada Monumento Nacional. Finalizando, vale lembrar que isso se concretizou a partir da aproximação do grupo modernista ao Ministério da Educação e Saúde Pública de Gustavo Capanema para a criação do SPHAN.

A criação dessa nova cidade contou com grande alteração na sua arquitetura, levando a um redesenho desse barroco mineiro, conhecido como colonial, em função de uma imagem mais "coerente" com a memória que se pretendia consolidar. Porém, a forma urbana não sofreu muita alteração, seu traçado e seu tecido urbano são, de certa maneira, originais.

A política patrimonial de restauração que contribuiu para fazer de Ouro Preto um mito, manteve a tendência de reproduzir certas formas eleitas como "autênticas", a fim de manter "a harmonia do conjunto". A cidade hoje mostra poucos traços da arquitetura doméstica extremamente simples, da época da corrida do ouro. (SALGUEIRO, 1996, p. 127) 
A partir dessa construção de imagem de cidade, Ouro Preto passa a ser entendida como uma obra de arte, no sentido de que ela não viria a sofrer grandes modificações e permaneceria inalterada. Uma visão um pouco inocente, pois não leva em consideração a noção de ser uma cidade em si, de ter vida, de ser dinâmica e estar em constante alteração.

A consolidação de tal imagem foi um grande passo para a posterior construção de Ouro Preto como destino turístico. A formação da "cidade histórico-turística" se deu por meio de um longo processo que teve início, de fato, próximo da década de 1950.

Nesse processo, fica evidente uma aproximação da questão patrimonial com o turismo, entendida dentre outras maneiras, como um meio de melhorar a ação preservacionista, sendo que cada vez mais aumentam as verbas destinadas ao campo turístico.

\footnotetext{
Em diversos momentos observamos uma convergência de interesses entre as políticas preservacionistas e os projetos de desenvolvimento turístico da cidade, percebidos como a solução para muitos dos problemas que dizem respeito à salvaguarda do antigo conjunto urbano tombado em nível federal desde 1938. (AGUIAR, 2013, p. 189)
}

Além da questão turística, há outros dois fatores que contribuíram para a expansão urbana de Ouro Preto no século XX: a instalação da indústria ALCAN, em 1945 e a criação da UFOP, em 1969. As duas se localizam na parte sul da cidade, constituindo uma nova centralidade e gerando um grave impacto na malha urbana existente, tanto na periferia quanto no centro. "A partir de meados do século $X X$, a cidade passou a sofrer um processo de saturação na ocupação do núcleo central e de expansão em direção à periferia". (VIEIRA, 2016, p. 203)

Essas instalações geraram um crescimento urbano desordenado e diferenciado no núcleo histórico central com a necessidade de novas habitações e novos arruamentos. O que pode ser confirmado com a taxa de crescimento populacional, em 1950 era de 8.751 habitantes e, em duas décadas depois, passou para 25.252 habitantes. (SALGADO, 2010)

Há uma consideração a ser feita aqui no que diz respeito à conservação da cidade de Ouro Preto e ao crescimento desordenado, as primeiras preocupações relacionadas a preservação apenas levavam em conta o monumento histórico, não reconhecendo a importância do conjunto urbano. Isso advém das teorias de preservação que circulavam no mundo. Segundo Marina Salgado (2010, p. 15), "a ampliação do conceito de conservação do monumento histórico para sua conservação e a de seu entorno vai ser marcada pela figura de Gustavo Giovannoni (1873 - 1947)", o qual alegava que o entorno do monumento mantinha uma relação essencial com ele. É, em seguida, com a Carta de Veneza, em 1964, que se consolida a importância de o monumento estar intrinsecamente ligado ao contexto em que está inserido.

O que se percebe, de fato, é que tal conceito não é levado muito em consideração e quando se diz que a cidade de Ouro Preto é tombada significa que é o seu núcleo histórico e não seu todo, fragilizando bastante a paisagem desse núcleo. 
legislação de Uso e Ocupação do Solo que considere as qualidades da paisagem como elemento de preservação nos núcleos históricos. (SALGADO, 2010, p. 15)

No tópico a seguir será mostrado de que modo se deu a expansão urbana desordenada de Ouro Preto e quais suas consequências na paisagem.

\section{Implantação urbana}

Retomando o que já foi dito, as modificações que ocorreram no século XIX não foram bem aceitas no século XX e geraram o Decreto $n^{\circ} 13$, em 1931, o qual proibia, no perímetro urbano, a construção de edificações que estivessem em desacordo com o estilo colonial da cidade. Como medida foi estabelecido um prazo para a adequação das fachadas que estavam descaracterizadas. (VIEIRA, 2016, p. 186)

Em 1949, o arquiteto do IPHAN, Sylvio de Vasconcellos, cria um inventário do núcleo urbano de Ouro Preto com a intenção de levantar um estudo sobre o estado de conservação das residências para depois começarem os trabalhos. O que se notou com esse levantamento foi o grande número de casas em mau estado de conservação, muitas delas praticamente em ruínas. Isso sem contar as inúmeras casas que desapareceram. O conjunto urbano encontrava-se em estado precário e a medida a ser tomada precisava de urgência. Cabe lembrar que a situação de Ouro Preto era remanescente do declínio após a mudança da capital. Para ter uma base quantitativa, em 1917, o número de casas na sede do município era de 1.436; em 1949, existiam apenas 963 prédios, ou seja, em trinta e dois anos, desapareceram 473 casas. (VIEIRA, 2016, p. 144)

O inventário foi de extrema importância para um início dos estudos acerca da cidade de Ouro Preto, ainda que tenha se restringido ao núcleo histórico. Além disso, insere-se dentro de um período intermediário de atuação do IPHAN. Intermediário no sentido de que antes já havia ação preservacionista, ainda que em número muito irrisório, e depois de modo mais intenso e superficial, contribuindo para a aparência falsificada do conjunto, como mostrado a seguir.

Nas primeiras décadas de atuação, o IPHAN analisava cada caso separadamente quanto à questão do controle da preservação. Isso porque haviam poucos casos e acreditava-se que a cidade não iria mais crescer. Entretanto, a partir da década de 1960, Ouro Preto começou a se expandir e, por meio dessa solução, acabaria perdendo o controle. A medida adotada foi substituir tais critérios isolados por normas.

O objetivo era fixar condições para que as construções dos futuros bairros - dentro do perímetro tombado - não perturbassem a visibilidade, integridade e ambiência do conjunto urbano.(VIEIRA, 2016, p. 209).

A atuação do IPHAN passou a influenciar a forma urbana das novas áreas ocupadas. Com a incorporação dessas normas, os projetos adquirem uma mesma aparência, denominada de "estilo patrimônio", que foi um padrão elegido pelo IPHAN de uma fase de Ouro Preto para homogeneizar a imagem da cidade. aprovação de projetos novos, estes deveriam obedecer a normas das 
[Figura 9] Setores de ocupação da cidade de Ouro Preto.

[Fonte] Croqui elaborado pela autora com base em SALGADO, 2010, p. 115. tipologias coloniais, confundindo-se, assim, o patrimônio real e as construções dotadas do chamado "estilo colonial". (SALGADO, 2010, p. 107)

A arquitetura que então era uma reprodução estilística da tipologia colonial, acabou por perder seu sentido e qualidade, descaracterizando a paisagem urbana. Isso ocorreu porque o IPHAN não estava preparado para conduzir áreas urbanas. "Os antigos caminhos, antes desocupados, foram preenchidos por edificações 'estilo patrimônio' ou 'pseudocoloniais'. “(VIEIRA, 2016, p. 220)

Diante disso, fica cada vez mais difícil avaliar a produção arquitetônica da cidade, na tentativa de distinguir o que é remanescente e espontâneo da época colonial e o que foi imposto por meio do processo de falsificação e construção dessa imagem de cidade que se conhece.

Partindo-se para a consequência dessas questões no traçado urbano, é possível perceber que até meados do século $X X$ este não sofreu grandes alterações, mesmo porque é quando o cenário, até então, decadente de Ouro Preto passa a ser transformado principalmente pela incorporação da ALCAN, da UFOP e do turismo, como já visto. Nesse sentido, ocorre uma expansão que se desenvolve no sentido leste-oeste e outra no sentido norte-sul.

Marina Salgado (2010, p. 114) fala de uma divisão, bastante clara por meio de barreiras físicas, em 4 setores na malha da cidade.

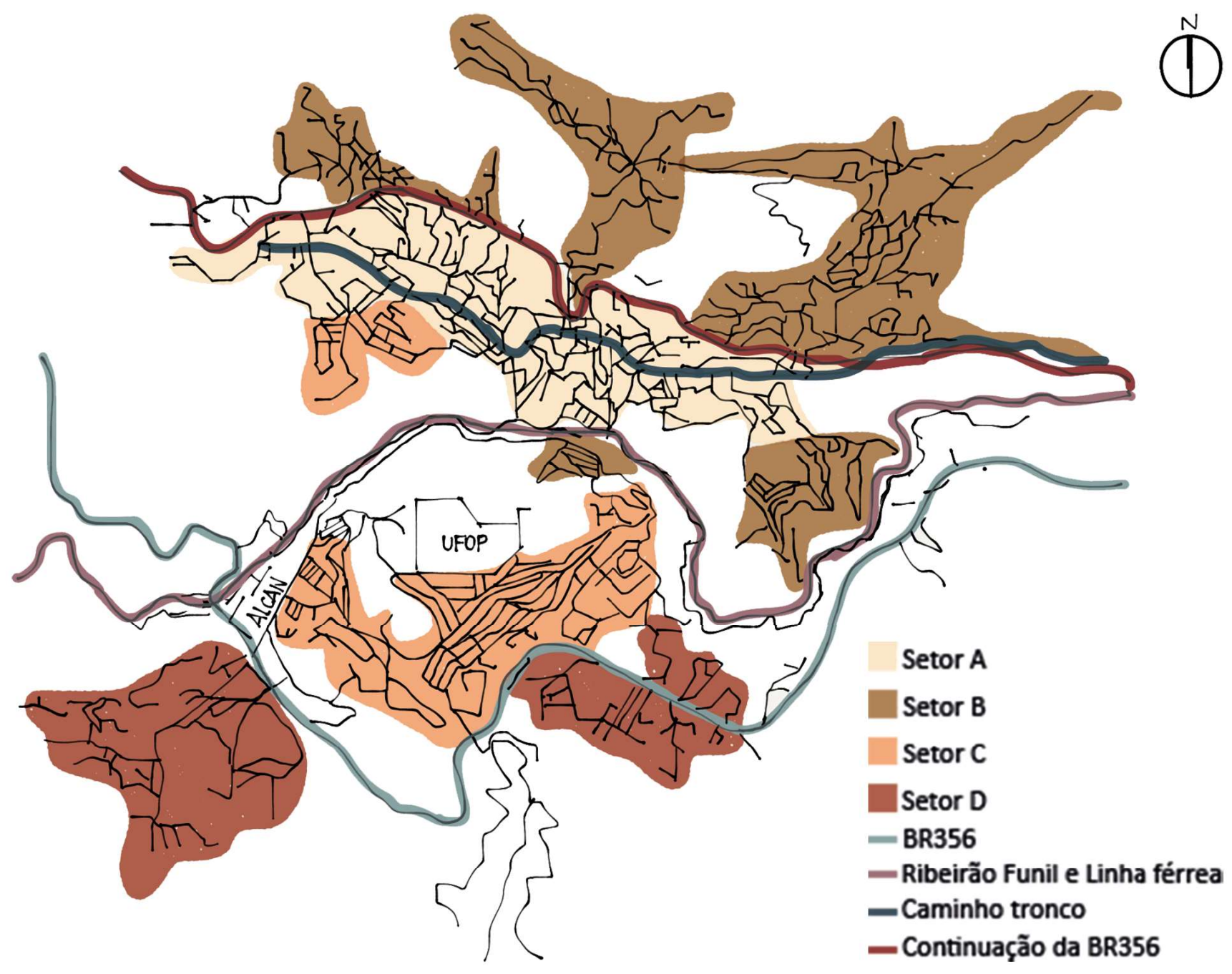


Setor A, marcado pelo núcleo histórico tombado pelo IPHAN; o setor $B$, formado pelas ocupações de encosta localizadas na porção norte da cidade; o setor $C$, representado principalmente pelas ocupações do vetor sul; e o setor $\mathrm{D}$, correspondente aos bairros do extremo sul da cidade.

Segundo Salgado (2010), em síntese, o setor A diz respeito a malha urbana formada ao longo do caminho tronco na formação da cidade, no início do século XVIII. Os lotes, na maioria das vezes, apresentam-se seguindo o padrão do Setecentos, alinhados com a rua, testada estreita e profundos. A tipologia residencial predominante é a colonial, embora exista edificações 'pseudocoloniais'. Uma arquitetura híbrida que se utiliza de alguns elementos coloniais, não sendo possível identificar claramente uma ou outra, o que contribui para a construção do cenário que virou Ouro Preto com a inserção do turismo e do seu desenvolvimento baseado na produção de mercado.

O setor $\mathrm{B}$, corresponde a ocupação ao norte, situada em terrenos de alta declividade e que comprometem a visualidade do conjunto histórico. A morfologia do relevo influencia na ocupação. As vias se inserem perpendiculares às curvas de nível, a ocupação é esparsa no terreno e as edificações geralmente possuem dois pavimentos, devido à declividade, e as fachadas não são bem-acabadas. "A principal característica deste tecido é sua visibilidade a partir do núcleo histórico. O impacto destas ocupações pode ser percebido de vários pontos do núcleo." (SALGADO, 2010, p. 120)

O setor $C$, advém da ocupação ao sul influenciada pela implantação da linha férrea, da ALCAN e da UFOP. A intensa ocupação desse setor gera o adensamento dos lotes e a falta de um padrão de implantação, sendo difícil encontrar áreas livres. As edificações são mais recentes e seguem o padrão induzido pelo novo modo de morar incorporado pela ALCAN e UFOP. Esse setor não causa impacto visual no setor $A$, pois se encontra em uma cota mais baixa que o núcleo histórico.

O setor D, expandiu-se devido ao mesmo fator do setor $C$, no entanto, ocorreu em uma fase posterior, ocasionando o surgimento de uma nova tipologia. O adensamento aqui é bem menor que no setor $C$, sendo assim, os lotes apresentam dimensões reduzidas e as edificações possuem um padrão de acabamento pior e se encontram em uma cota mais baixa que o setor $A$, não gerando impacto.
[Figura 10] Vista de Ouro Preto atualmente.

[Fonte] Foto feita pela autora, 2017.

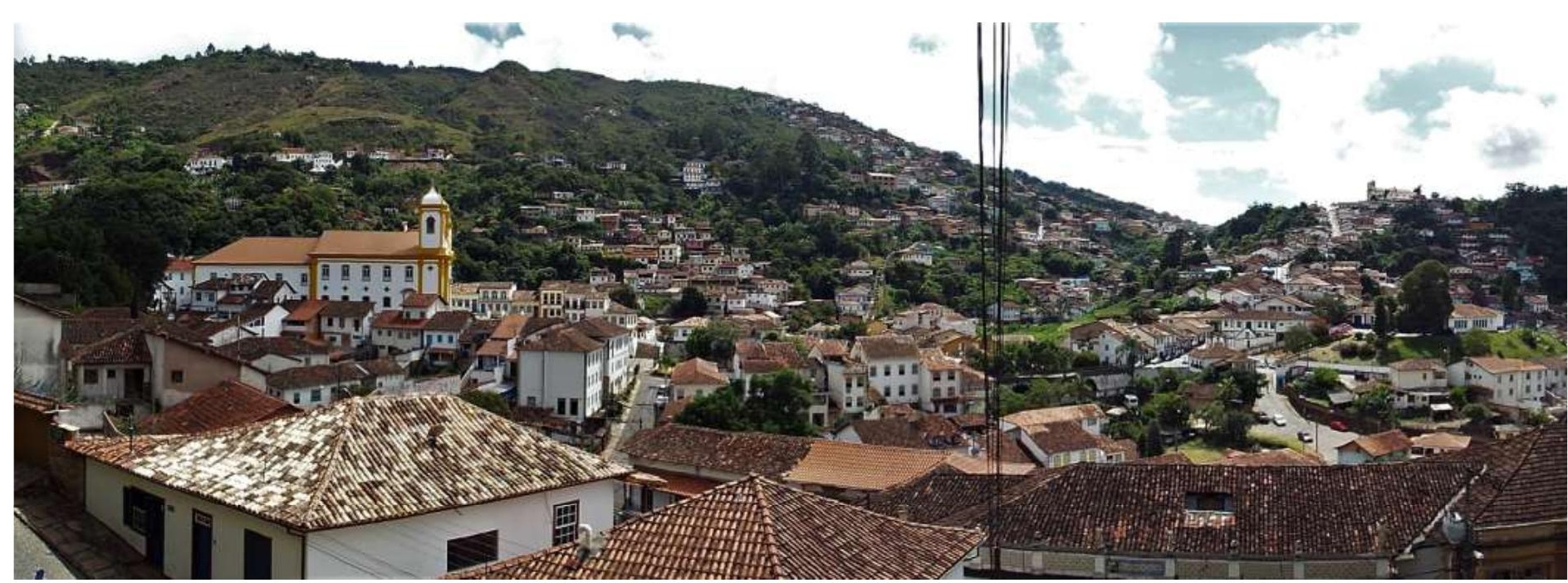


[Figura 11] Vista de Ouro Preto na primeira metade do século $\mathrm{XX}$.

[Fonte] Acervo Fotógrafo Luiz Fontana, Instituto de Filosofia, Artes e Cultura (IFAC).

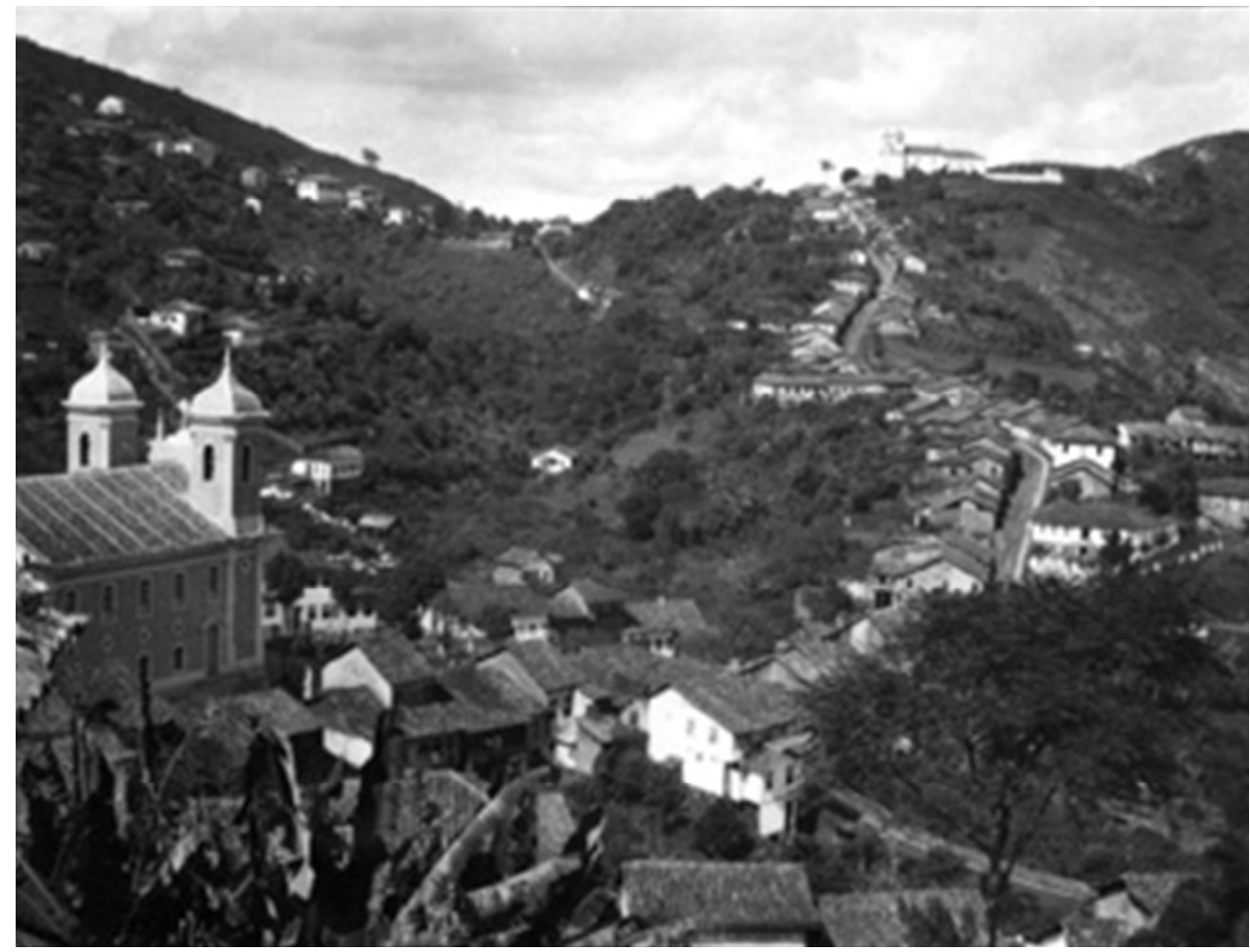

[Figura 12] Vista de Ouro Preto atualmente.

[Fonte] Foto feita pela autora, 2017.

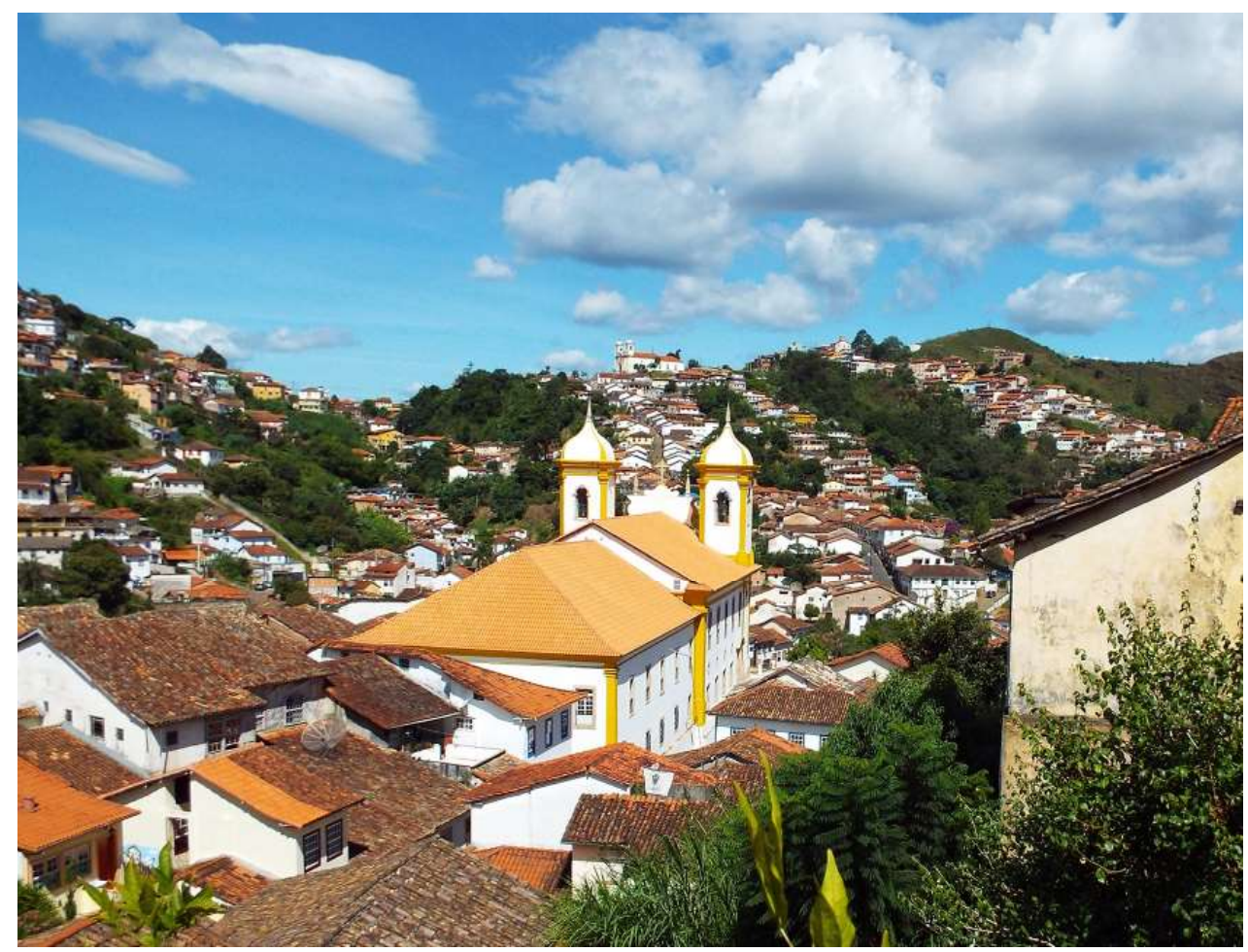

Essa setorização mostra que a preocupação com a preservação ocorre de forma intensa no núcleo tombado e que, nos demais setores, o crescimento foi desordenado. A consequência disso ou é a saturação do solo, causada pelo adensamento, ou o impacto visual, marcado pela ocupação nas encostas, paisagem montanhosa tão característica desse lugar.

A atenção voltada para o núcleo tombado aumentou ainda mais na década de 1980-90 quando a produção arquitetônica do conjunto se volta para a política de mercado. Ao recriar elementos coloniais, o espaço passa a ser cenográfico e tudo é pensado para atrair os turistas. Além disso, o que se tem hoje é uma saturação da área central e uma alta densidade de ocupação na cidade como um todo. 


\section{Ouro Preto Turística}

O cenário de culto à nação foi não só o ponto de partida para a preservação da cidade, mas também proporcionou a elevação de Ouro Preto como bem simbólico e, consequente, como atrativo turístico. Sendo assim, pode-se entendê-la como uma construção social. "A cidade é um artefato, produzido socialmente de modo complexo, em relação ao tempo e ao espaço". (ANDRIOLO, 2009, p. 160)

Nesse sentido, fica evidente uma aproximação da questão patrimonial com o turismo, entendida dentre outras maneiras, como um meio de melhorar a ação preservacionista, sendo que cada vez mais aumentam as verbas destinadas ao campo turístico.

Em diversos momentos observamos uma convergência de interesses entre as políticas preservacionistas e os projetos de desenvolvimento turístico da cidade, percebidos como a solução para muitos dos problemas que dizem respeito à salvaguarda do antigo conjunto urbano tombado em nível federal desde 1938. (AGUIAR, 2013, p. 189)

Do mesmo modo que aparece a inserção da política em meio a construção do caráter nacional de Ouro Preto, como visto anteriormente, retoma-se aqui. As ações políticas e os investimentos no setor turístico, juntamente com os desdobramentos na imprensa e nas agências de viagem, possibilitaram perceber a cidade mineira de outra forma, agora sobre os olhos do turista.

Como já dito, a atividade turística em Ouro Preto tem início a partir de 1950, no entanto, atinge maior destaque a partir de duas décadas depois, quando a organização empresarial de agentes de viagens, operadoras, proprietários de hotéis e projetos governamentais consolidam o produto turístico que conhecemos como cidades históricas mineiras. (ANDRIOLO, 2009, p. 164)

Na década de 1990, a política neoliberal implantada no país,

acabou por ser incorporada na vida contemporânea, ao transformar os núcleos históricos preservados em cenários para o consumo e para a satisfação das necessidades de lazer da sociedade. Assim a difusão do turismo e a crescente valorização econômica dos bens culturais, promoveram a consagrada união entre turismo e patrimônio cultural. (OLIVEIRA; VITTE, 2004, p. 13)

Voltando à década de 30 , já se pode ver algo que se aproxima concretamente ao turismo, o Guia de Ouro Preto escrito por Manuel Bandeira. Por mais que o nome pressuponha uma atividade turística, difere bastante do que conhecemos hoje como algo que informe e seduza o turista. Naqueles escritos há uma mescla da história da cidade e sua formação com informações relevantes a quem viesse a conhecê-la.

O que percebemos com os guias turísticos atuais é, de certa maneira, uma distorção da realidade, uma vez que as imagens produzidas e os discursos sobre elementos do conjunto urbano são produtos de mercado e, por isso, precisam impactar para serem vendidos. Diferentemente do Guia de Manuel Bandeira, cujo objetivo maior era mostrar a literatura de interesse nacional para a sociedade. 
Entre esses dois momentos, aparece a difusão da imagem fotográfica supostamente documental, pela sua proximidade com a realidade figurada. Esse conjunto de imagens é incorporado aos documentos visuais da cidade histórica, criando assim um cenário mais propício para o turismo e também "um modelo para a percepção do turista". (ANDRIOLO, 2009, p. 164)

Como se vê atualmente, o grande meio de divulgação do turismo é a imagem. As belas imagens de pontos específicos da cidade fazem com que o turista já comtemple o lugar antes mesmo de conhecê-lo, ou melhor, contemple a cidade de uma maneira que não é real, mas sim distorcida. É a

Invenção e a mitificação da realidade e dos lugares, por parte da mídia e dos agentes de viagem, para que eles possam ser vendidos previamente, como uma mercadoria turística, de exploração simbólica, imediata e superficial. (OLIVEIRA; VITTE, 2004, p. 8)

Como consequência disso, vê-se uma cidade construída no imaginário do turista e esperada como tal por ele. Em outras palavras, a divulgação do lugar turístico cria uma expectativa para o turista, o qual vai em busca do lugar que Ihe foi mostrado. Conforme Melissa Oliveira e Claudete Vitte (2004, p. 8), o movimento turístico torna-se pobre e superficial porque esse turista-consumidor não deseja reflexão, introspecção, envolvimento ou dúvidas, realiza apenas, uma leitura superficial do espaço.

A resposta sobre isso aparece na forma de novas imagens, agora gerada pelo olhar desse turista. Ao tentar encontrar o que procura, por meio da sua percepção sobre o espaço já condicionada, muitas vezes o turista acaba por reproduzir o que conhece de antemão. Isso pode ser observado nas imagens compartilhadas nas redes sociais. Com a utilização de filtros, de ferramentas que criam uma nova aparência para a imagem, o resultado final parece se assemelhar muito ao que é encontrado nos produtos vendidos pelas agências e guias turísticos. É instaurado um processo de reprodução de imagens superficiais, por meio do qual o turista é afastado da experiência do lugar visitado. 
parte II 
capítulo I

Guignard 


\title{
Guignard pessoa
}

Guignard nasceu em 1896 na cidade de Nova Friburgo, Rio de Janeiro. Foi o primeiro filho de Alberto José Guignard (1866-1906) e de Leonor Augusta da Silva Veiga Guignard (1873-1926), apenas quatro anos mais tarde nasceu a segunda filha, também chamada Leonor. ${ }^{[1]}$

Sua vida foi marcada por uma série de acontecimentos dolorosos, dentre eles, e talvez o mais difícil, foi a presença do lábio leporino. Guignard nasceu com abertura total entre a boca, o nariz e o palato, sofreu muito para se alimentar e para falar. Desde a infância muitas foram as cirurgias feitas para corrigir esse defeito, mas não obtiveram sucesso. No entanto, somente quando já era adulto, a cirurgia teve como resultado o fechamento parcial do lábio superior, o que mesmo assim ainda não o impedia de regurgitar os alimentos e não diminuía a dificuldade de falar. Como complementa Leila Frota (1997, p.11),

\begin{abstract}
Se, por um lado, Guignard desenvolveu a partir dele um repertório mímico e gestual da maior inventividade e sempre se fez compreender - a ponto de se relevar um professor de extraordinária eficácia -, por outro, isso teria contribuído para a irrealização da sua vida amorosa, para a constituição da família a que ele tanto almejou.
\end{abstract}

Quando Guignard tem aproximadamente 5 anos, a família muda-se para Petrópolis em um chalé. Esse período e essa residência foram marcantes para o artista, como será mostrado mais para frente as lembranças de sua infância estarão presentes em sua pintura. Tudo se passava bem, quando em 1906 mais um acontecimento trágico ocorre em sua vida: a morte do pai. Como consequência disso, a família vai viver no Rio de Janeiro.

Sua vida, que já não era tão feliz quanto em Petrópolis, acaba se tornando ainda mais difícil quando sua mãe, em 1907, casa-se com um alemão, o barão de Schilgen. A maior dificuldade estava no desafeto claramente demonstrado ao menino. No mesmo ano, a família vai para a Europa, onde vivem por um longo período. Guignard apenas retornará ao Brasil definitivamente em 1929, com 33 anos.

Dentre os acontecimentos mais relevantes desse período está a ida da família a Munique, em 1915, onde conclui seus estudos preparatórios. O padrasto, querendo se ver livre do enteado, interna-o em uma fazendaescola em Freising, próximo a Munique, para se formar em agronomia ou zootecnia. No entanto, Guignard adoeceu na escola e sua mãe o levou de volta a Munique. Vendo o que seu filho desenhava, ela concluiu que ele tinha vocação artística e, a partir daí, puseram-no na escola de pintura Real Academia de Munique. Durante sete anos, teve um rigoroso e intenso aprendizado de desenho. Cabe um adendo aqui, depois de ter alcançado sua carreira artística, Guignard diz que valeu o sofrimento. "Naturalmente aprendi pelos modos acadêmicos, mas depois meu instinto pessoal me guiou para a minha personalidade e liberdade completa“. (GUIGNARD apud FROTA, 1997, p. 18). Esse caminho pessoal será visto mais à frente, ao mostrar seu papel como artista e professor de desenho.

[1] Capítulo baseado principalmente no livro FROTA, L. C. Guignard: arte, vida. Rio de Janeiro: Campos Gerais, 1997.
Em meio tempo aos estudos ainda em Munique, no final de 1922, outro fato marcante ocorre, esse como consequência de uma paixão pela estudante de música de 25 anos, Anna Doring, que resultou em casamento cerca de três meses após terem se conhecido. A união não durou muito e, em plena lua-de-mel, Guignard foi abandonado pela esposa. 
Em 1924, Guignard vem para o Brasil e participa da Exposição Geral de Belas Artes com cinco desenhos e um autorretrato. Além disso, mantém contato com a Associação de Artistas Brasileiros. Lembrando que neste mesmo ano, acontece a expedição modernista de 1924 a Minas Gerais, com a qual Guignard não se relaciona, pois seus contatos maiores com o Brasil se darão apenas anos mais tarde quando volta, definitivamente, ao país. Depois que vai embora do Brasil, em 1924, Guignard vai a Florença e instala um ateliê, onde consegue se dedicar aos seus estudos e progressos artísticos.

Outras perdas dolorosas acontecem na vida de Guignard. Em 1926, falece sua mãe e dois anos mais tarde, em 1928, falece sua irmã, vítima de tuberculose. Em 1929, Guignard está com 33 anos, trabalhando bastante, com várias portas se abrindo, porém, sozinho na vida. Diante dessa solidão, o artista decide voltar de vez para o Brasil.

Sua chegada ao Brasil, em 1929, acontece logo no final de República Velha e o contexto em que desenvolve suas obras no Rio de Janeiro é o do Governo Vargas, que a grosso modo, estende-se de 1930 a 1945, com destaque à ditadura do Estado Novo em 1937.

A luz e as cores do país de onde ficara ausente por tantos anos é que permitem a Guignard a retomada de contato com o Brasil, aos poucos, pela observação atenta, permanente, e por uma "paciência, perseverança e sinceridade" enormes - que ele mesmo recomendava a seus alunos/colegas. (FROTA, 1997, p. 54)

Nesse período de permanência no Rio de Janeiro, Guignard pintou várias vezes o Jardim Botânico, gostava muito de observar a natureza e representá-la, nesse processo vai reencontrando a luz e a cor do seu país.

Logo acontece o Salão de 1931, no qual Guignard participa com o maior número de obras, com um total de 27. Lembrando que o Salão foi criado por Lúcio Costa quando este era diretor da Escola Nacional de Belas Artes e teve grandes repercussões no campo da cultura e da arte moderna.

Guignard participa de vários Salões tanto no Rio de Janeiro como em São Paulo e são também pelas repercussões neles que Guignard acende na sua carreira artística, já que obteve muitas premiações, medalhas de ouro, prata e bronze com suas obras. Foi a partir desse reconhecimento que o artista adquiriu prestígio, pode viajar para conhecer vários lugares do país e foi chamado para lecionar em escolas públicas. Seu percurso como professor foi muito peculiar e intenso.

Cabe destacar que sua vida era um pouco conturbada. Além de todos os fatos pontuados anteriormente, inclui-se aqui sua vida financeira. Não se importava muito com dinheiro, na verdade, não sabia administrar o que ganhava, primeiro porque era muito sensível e bondoso e saia presenteando as pessoas com suas pinturas; segundo porque o vício pela bebida era grande e, por vezes, aceitava trocar quadros por garrafas de cerveja. Sua sorte foi ser querido pelas pessoas e ter muitos amigos, com os quais podia contar. Sem moradia fixa, o artista vivia se hospedando na casa dos amigos. Rodrigo Naves (1992, p. 12) resume a vida do artista dizendo que

A bondade de Guignard era proverbial: balas para crianças, um despojamento sem par, desprezo pelo sucesso mundano, extrema dedicação aos alunos, a ingenuidade em relação ao dinheiro etc. $E$ 
no entanto, quando chegava a hora, trocava por álcool qualquer uma de suas poucas posses.

Essa ingenuidade citada por Naves (1992) levou Guignard a ter atitudes que fugiam as regras estabelecidas pelo sistema, por exemplo, quando alguém Ihe pedia um quadro e ele não tinha nenhum feito, pegava uma pintura de um aluno, dava uns retoques, assinava e presenteava. No entanto, não fazia por maldade, era apenas a maneira que via para não desagradar quem gostava, tamanha sua bondade. Além disso, era por meio da pintura que se comunicava, sua dificuldade com a fala - por conta do lábio leporino - consegue ser revertida para a expressão na pintura.

O que ele fazia era uma troca, um pouco de amizade por um pouco de pintura, pintura essa que é a faceta bonita do Guignard feio, é o campo onde ele se comunica da melhor forma com o mundo que o cerca. (SCHENKER, 1983, p. 30)

Sua vida pessoal e profissional fazem parte do conjunto necessário para a compreensão do que foi esse artista e das relações afetivas que marcam a particularidade de suas obras. "Dados biográficos em geral são maus guias para a compreensão do significado de obras de arte. No caso de Guignard, contudo, existe tal simetria entre obra e vida que podemos ao menos retirar daí uma paráfrase reveladora". (NAVES, 1992, p. 12). Ainda como diz Frederico Morais (2000, p.19),

Todos estes lances biográficos transparecem em sua pintura de modo tão intenso, que é impossível não considerá-los na avaliação de sua obra, marcada por uma poesia mesclada de nostalgia e por um lirismo que será a base de seu humanismo criador. Em Guignard, portanto, há uma perfeita simetria entre obra e vida.

Lembrando que o que foi dito acima, é descrito por Merleau-Ponty acerca da sua reflexão teórica sobre Cézanne: não é que a vida do pintor nos explique a sua obra, ou ainda, que o sentido da sua obra seja determinado por sua vida, mas sim que obra e vida se comunicam e que, se conhecemos sua obra anteriormente, conseguimos vê-la através das circunstâncias da sua vida. É isso que buscamos ao situar, primeiramente, a biografia de Guignard, seus passos na profissão e, por fim, mergulhar na leitura de suas obras. "Se por um lado a pintura está ligada à vida, por outro lado ela não é mera ilustração da biografia, uma exteriorização pura e simples da personalidade“. (SCHENKER, 1983, p. 27)

No entanto, no ano de 1942, vários acontecimentos são positivos para o artista. O MoMA adquiriu uma pintura e um desenho dele, obteve medalha de ouro no $48^{\circ}$ Salão Nacional de Belas Artes, com uma obra de paisagem, e ainda recebeu um convite do Diretório Acadêmico da Escola Nacional de Belas Artes para realizar uma exposição com suas obras, num total de 74 . Tais fatos vieram a consolidar a importância de Guignard para o campo da pintura brasileira e foram o início para a presença de Guignard na cidade de Ouro Preto, ponto principal para essa pesquisa.

Guignard foi levado a conhecer a cidade por Manuel Bandeira, como descreve Pierre Santos, professor e crítico de arte e amigo do artista: 
embasbacado. Isso foi em 1942. Ele havia ganhado o Prêmio do Salão Nacional, no Rio de Janeiro, e veio conhecer Minas. Foi o poeta Manuel Bandeira que o aconselhou: "Vá pra Minas que tem tudo a ver com você." Mário Silésio conta que eles chegaram à noite em Ouro Preto, após o dia inteiro de viagem. Guignard, cansado, não quis ver nada e foi dormir. No dia seguinte, acordou cedo e não sabia dizer uma palavra, maravilhado com o que via. Então exclamou: "É isso que eu procurei a vida inteira. Eu quero viver é aqui". (SANTOS, 2003, p. 04)

Manuel Bandeira (1986, p. 57), anos mais tarde vai caracterizar esse olhar particular de Guignard sobre a paisagem de Ouro Preto:

[Em Minas] quem mais ganhou com a presença de Guignard foi Ouro Preto, que hoje está definitivamente tombada na obra do pintor [...] A Ouro Preto de Guignard não é triste, Guignard remoça Ouro Preto, sem no entanto a descaracterizar.

A cidade de Ouro Preto forjada nesse processo encanta Guignard pelas possibilidades poéticas que tal cenário tinha em estado de latência. Veremos melhor, posteriormente, seu percurso e sua produção nessa cidade mineira. Todavia, passaremos antes para a etapa da vida de Guignard como professor, de certo modo, uma continuação da biografia até aqui colocada.

\section{Guignard professor}

Os primeiros contatos de Guignard com o meio acadêmico aconteceram logo após sua chegada ao Brasil. Um deles em 1935, quando o cenário do Rio de Janeiro, então capital do país, alterava-se diante do espírito moderno impulsionado pela Semana de 22. Neste ano, o secretário da educação e cultura, Anísio Teixeira criou a Universidade do Distrito Federal. Dentro da Faculdade de Filosofia foi criado o Instituto de Arte, no qual Guignard lecionou desenho por seis meses. Dois anos após sua inauguração, a Universidade foi extinta pelo Governo Vargas. (FROTA, 1997, p. 42)

Com presença mais duradoura, Guignard leciona na Fundação Osório, de 1931 a 1943. Fundação criada em 1908, "para dar amparo a meninas órfãs de soldados das forças armadas". (FROTA, 1997, p. 43). É notável o papel de Guignard e sua maneira peculiar de ensinar desenho. Era muito entusiasmado com o seu trabalho e transpassava isso da melhor maneira possível para suas alunas. Dava a elas a liberdade para fazer acontecer a imaginação delas, sem se restringir a métodos rigorosos.

Como já dito, o ano de 1942 foi muito positivo para Guignard. Nesse ano ele ministra aulas gratuitas no terraço da União Nacional dos Estudantes. O curso tem duração de dois meses e dentre os alunos estão nomes como Iberê Camargo, Maria Campello, Geza Heller, Elisa Byington, dentre outros, que posteriormente passaram a ser conhecidos como o Grupo Guignard. Um dos casos, que contribuiu para os modernos terem o seu próprio museu, foi o episódio marcado pela exposição do Grupo Guignard no Diretório Acadêmico da Escola Nacional de Belas Artes, em 1943, cujo resultado foi a depredação da exposição por uma vertente acadêmica da Escola. "Enciumado, o diretor da escola, fascista notório, estimulou alguns alunos a desmontá-la violentamente, resultando na destruição de várias obras, provocando repulsa geral do meio intelectual carioca“. (MORAIS,

[Quadro 3] Linha do tempo elaborada pela autora, 2017. Página ao lado. 


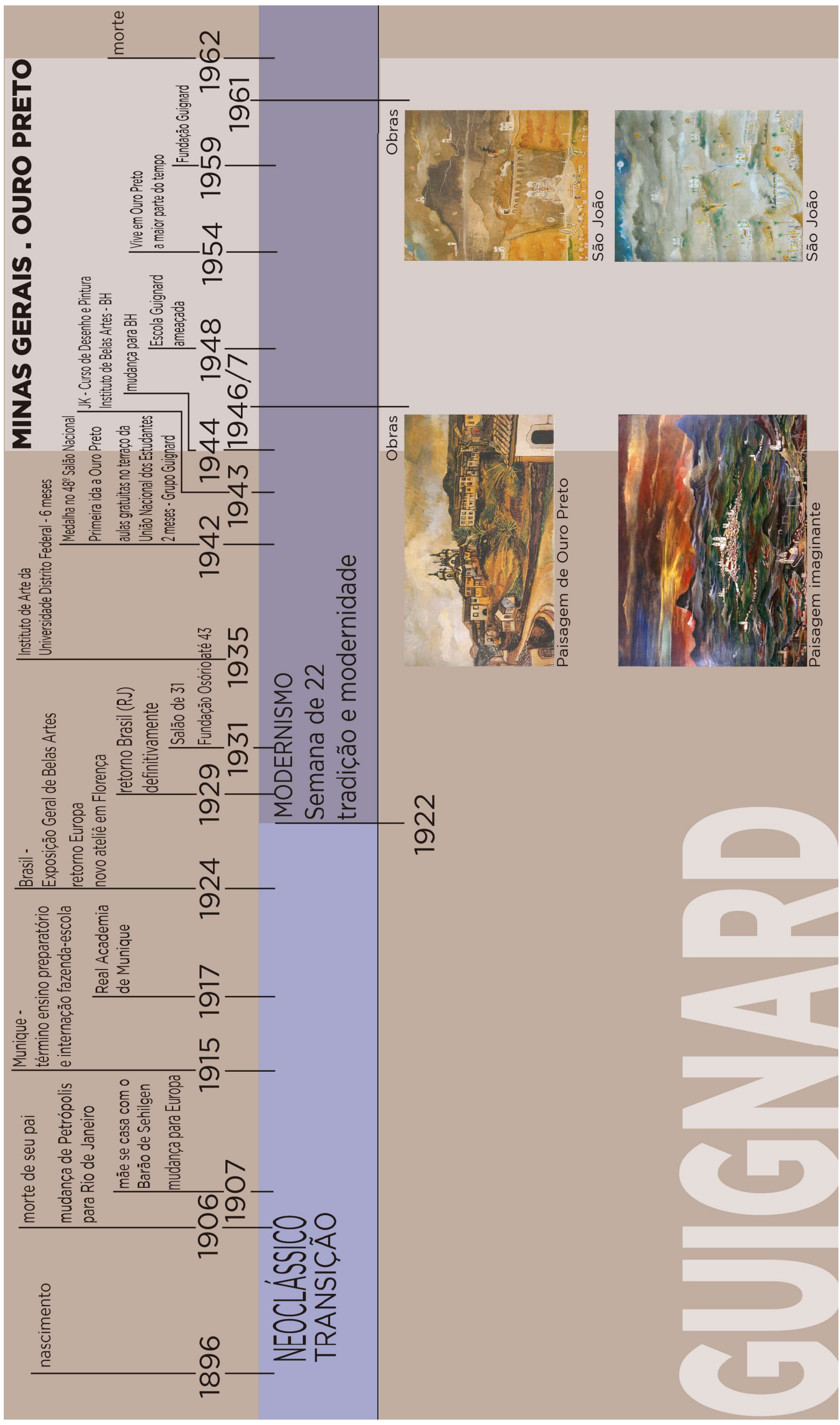


2000, p.12). Para alegria dos modernos, anos mais tarde, em 1948, acabou sendo criado o Museu de Arte Moderna do Rio de Janeiro. (FROTA, 1997, p. 103-104)

Um dos integrantes do Grupo Guignard, Iberê Camargo (1992, p. 21), relata sobre o contato com o professor e sobre seu modo livre de dar aulas. "Desdenhava as teorias. Sua bússola era a intuição, essa estrela que norteia o artista. Eu o entendia por um simples gesto ou pela expressão da sua face. A linguagem dos pintores é muda, uma mímica especial“.

Ainda no ano de 1943, Guignard é chamado pelo então prefeito da capital mineira, Juscelino Kubitschek, para dirigir o novo curso de Desenho e Pintura, que será criado no Instituto de Belas Artes, no ano seguinte. O pintor se muda para Belo Horizonte, no começo de 1944, e o grupo Guignard se desfaz, mas os artistas do grupo não cessam as atividades artísticas. Guignard se desculpa por ter que deixá-los e diz que cada um já tem uma base sólida e suficiente para seguir seus passos sozinhos e encontrar sua personalidade.

Do mesmo modo como aconteceu quando Guignard chegou ao Rio de Janeiro, acontece quando ele se muda para Minas Gerais: precisava novamente se familiarizar com a luz e as cores desse novo ambiente, desta vez no Parque Municipal de Belo Horizonte. É esse contato com a natureza que Guignard quer florescer em seus alunos. (FROTA, 1997. p. 98)

No entanto, para compreender mais a fundo sua relação com os alunos e seu modo de ensinar, é preciso situar em que contexto entra Guignard em Minas Gerais. A arte ainda era muito relacionada ao academicismo formal, porém, presenciava-se o início de um projeto modernizador, advindo de Juscelino Kubitschek, contrário a uma sociedade focada na racionalização e na industrialização e focado na busca uma realidade mais humana. Guignard encontra aí um ambiente artístico fértil, devido a um conjunto de incentivos governamentais acerca da modernização.

O curso de Guignard tinha por meta libertar o aluno das injunções

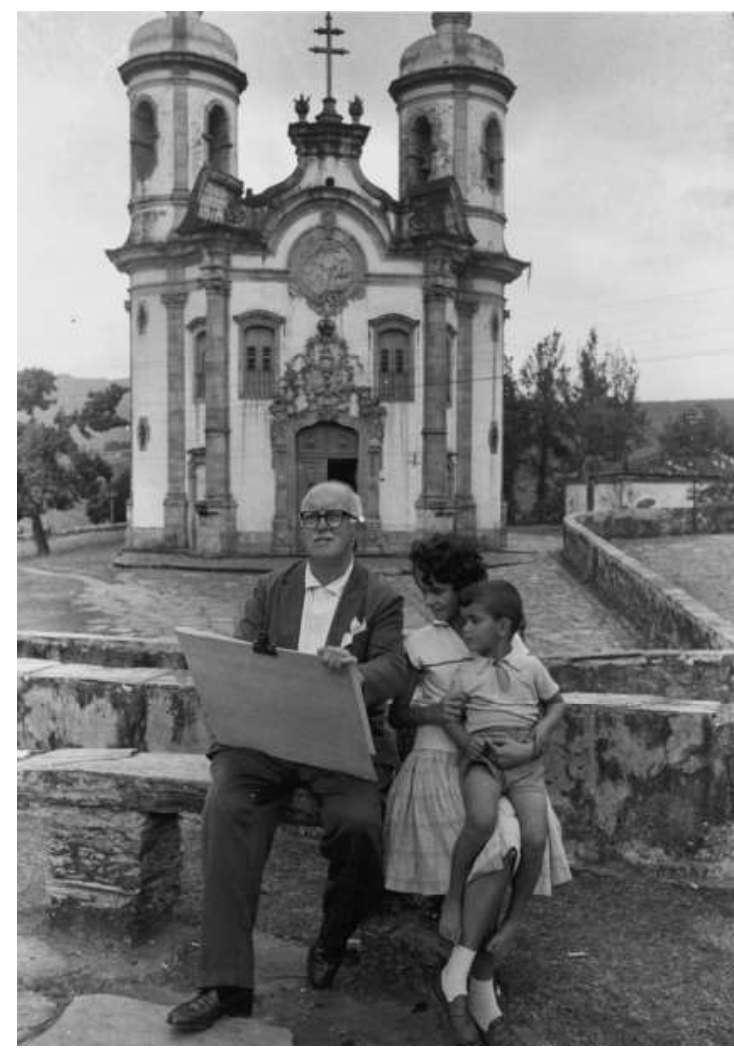

[Figura 13] Guignard em Ouro Preto, 1962, fotografia de Luiz Alfredo

[Fonte] Acervo Museu Casa Guignard 
massificantes do sistema, instaurando o confronto e superando as contradições entre a experiência humana e a realidade alienada". (VIEIRA, 1988, p. 10).

A grande oposição para o desenvolvimento da arte moderna em Belo Horizonte e, consequentemente, para Guignard vinha da Escola de Belas Artes de Aníbal Pinto de Matos, criada em 1927, sob os moldes acadêmicos e que, anos depois recebe uma subvenção federal e acaba se tornando "um reduto de forças academicistas e, portanto, contrário às tendências modernistas" (KLABIN, 1983, p. 43)

O Instituto de Belas Artes era composto pela Escola de Arquitetura e pela Escola de Belas Artes. Todavia, houve discordâncias quanto ao modo de ensino e as duas escolas acabam se separando. Em 1946, a Escola de Arquitetura fará parte da Universidade de Minas Gerais e o Instituto, agora somente com a Escola de Belas Artes, perde força e se acaba. O Curso Livre de Desenho e Pintura confiado a Guignard, com missão específica, transformava-se, de maneira autônoma, nessa casa de arte e ensino, que é hoje, a Escola Guignard e que de 1944 a 1962, recebeu várias denominações informais: Escola do Parque e Escola de Belo Horizonte. O apoio à escola recebido pelo governo cessa com a gestão do prefeito Otacílio Negrão de Lima. Houve a tentativa de extingui-la e retirá-la da sede por conta de uma radical mudança da atitude oficial frente à Escola, mas Guignard e seus alunos reagiram e se instalaram em outros lugares, mantendo a Escola viva.

A presença da Escola Guignard será crucial para se romper com o meio acadêmico, podendo entendê-la como parte do processo de revolução cultural. Segundo Ivone Vieira (1988, p. 18), para Kubitschek, a arte deveria, enquanto criação subjetiva da pessoa humana, retornar à vida do cotidiano da cidade e se tornar um elemento mediador entre o homem e o mundo.

A chegada de Guignard, pintor, e sua atuação como professor fizeram com que o cenário artístico mudasse de direção e se instaurasse, a partir daí, uma nova ordem cultural-artística na capital do estado.

$\mathrm{Na}$ verificação da modernidade configurada dentro da produção artística em Minas Gerais Guignard tornou-se um ponto de referência essencial, pois é através da sua atuação como professor e artista plástico que vai sendo pouco a pouco estruturada uma nova tendência estética, que modificará sensivelmente as novas gerações de pintores que o sucedem. (KLABIN, 1983, p. 41)

As aulas dadas pelo pintor no Parque Municipal vai ser o marco inicial do movimento moderno em Minas Gerais. Pelo local onde aconteciam já se vê uma inovação e liberdade no modo de ensinar, distinta do que se conhece: aulas dentro de salas. Liberdade essa intrínseca ao ensinar de Guignard e já pensada por Kubitschek para a feição do Curso Livre de Desenho e Pintura.

Possivelmente terá sido o tratamento didático/democrático - aliado à sua formidável intuição e poder de comunicabilidade-, que Guignard conferiu ao seu curso até 1950, que possibilitou a existência, a partir dessa data, do que Antônio Paiva Moura chama de "liberalismo didático, com maior participação dos alunos, em verdadeira iniciativa discente". (FROTA, 1997, p. 142) 
Na opinião do artista plástico Fabio Miguez (2009, p. 207), Guignard produzia uma pintura a se esvair, que é muito mais interessante do que os caminhos mais rigidamente singrados. Anteriormente, enquanto o rigor acadêmico se destacava, Guignard vinha, em contrapartida, com seu ensino singular. Seu método não se baseava em conceitos teóricos, mas sim em experiências. Tinha um modo peculiar de ensinar: antes de começar o desenho, os alunos tinham que aprender a ver. Era preciso ter atenção no agora, "a observação da realidade exterior com a interioridade de cada um, possibilitava o despertar da liberdade criadora". (ANDRÉS, 1996, p. 319)

Segundo Morais (2000, p. 13), Guignard condenava a maneira como se ensinava desenho nas escolas, fazendo-se cópias de desenhos acadêmicos, pois acreditava que aprender fazer arte tinha um sentido muito mais amplo que um simples artesanato ou o domínio de uma técnica especifica, significava uma ampliação da percepção, para não dizer do próprio viver. Quanto à escolha do tema, isso era livre para os seus alunos. Guignard não se importava com o que desenhavam, mas sim como desenhavam. "A significação maior dessas realizações não estaria na escolha do tema, mas, na concepção de espaço, na organização estrutural da composição desses elementos, tendo em vista o confronto de realidades". (VIEIRA, 1988, p. 70)

Era um conhecimento adquirido por meio da observação, da percepção e, também, da concentração e integração total do sujeito com a paisagem. Um exercício que requer prática, que requer horas exaustivas de trabalho e paciência. Por isso que Guignard não deixava seus alunos usarem borracha. A borracha não pode fazer parte do seu desenho, porque não há traço certo e traço errado, há apenas traços que se sobrepõem na medida em que conseguem apreender melhor a relação entre si mesmo com aquilo que observa. Somente depois de fazer muitas vezes é que sua mão corresponde melhor ao seu processo perceptivo. Em conjunto a isso, a primeira coisa que Guignard falava para os alunos era para que usassem lápis duro. A dureza do grafite marcava tanto os traços no papel que o uso da borracha não seria satisfatório. Maria Helena Andrés (1996, p. 321) enquadra Guignard como "um mestre que ensinava uma arte de vanguarda, não ditava leis, mas fazia o aluno descobrir o equilíbrio e a proporção no próprio trabalho, sem demonstrações dogmáticas".

Apaixonado pelo que fazia, Guignard transpassava isso aos seus alunos.

A espontaneidade, a alegria, o entusiasmo pela vida, o prazer de descobrir cores novas nos céus e nas montanhas, nos reflexos das águas, nos cortes das árvores, nas manchas dos muros velhos, eram qualidades inerentes à sua personalidade. (ANDRÉS, 1996, p. 319)

A trajetória de Guignard como professor perdurou bastante, por mais que esse percurso não tenha sido fácil, principalmente depois de 1948. Quando a sobrevivência da sua Escola se encontrava seriamente ameaçada por conta do sistema que vigorava, intelectuais e políticos mineiros tiveram a ideia de criar a Fundação Guignard, ocorrida em 1959, para que todo o trabalho e importância do artista para a cultura mineira e, mais, brasileira não fosse perdida. Nessa época, Guignard já estava vivendo a maior parte do tempo em Ouro Preto, havia cinco anos. Sua morte ocorre em 1962 e, no ano seguinte, por conta de problemas político-sociais, a Fundação se extingue. Entretanto, ainda em 1963, a ideia de criar o Museu Guignard é 
reconhecida, embora só venha a se concretizar em 1987, em Ouro Preto. (VIEIRA, 1988)

\section{Guignard artista}

Dizia-se das capelas mineiras à época colonial, que elas eram simples e modestas por fora, para que não assustassem o fiel com manifestações de fausto. Era no interior da igreja que o fiel, quase em êxtase, deveria ser acolhido pela beleza da talha e da imaginária, e assim melhor amar a Deus. Com Guignard ocorre algo parecido. Num primeiro contato, suas obras parecem demasiado modestas. $\mathrm{O}$ deslumbramento vem aos poucos, com a descoberta de um mundo de sutilezas temáticas e formais. (MORAIS, 2000, p. 16)

Embora abordamos Guignard como um artista moderno, cabe fazê-lo com algumas considerações, já que o pintor mantinha uma certa autonomia em relação às mudanças ocorridas nas pesquisas plásticas de sua época. $E$, como consequência disso, não seguia as tendências e não se filiou a nenhum grupo, apenas queria fazer a sua arte, mostrar a verdade da sua arte sem se preocupar com o que ocorria no mundo artístico. É exatamente essa singularidade que torna o percurso do artista tão marcante.

[Figura 14] Guignard em Ouro Preto, 1962, fotografia de Luiz Alfredo

[Fonte] Acervo Museu Casa Guignard
Guignard, sem um programa preestabelecido, levado pela grande abertura do seu espírito e pela sua curiosidade, pela sua empatia e pela sua maneira solidária de ser, estará dando conta, sim, através da arte, recurso que lhe é próprio, da sociedade brasileira e do seu ambiente, inclusive através dos retratos de mulheres e homens de classe alta e média e da flora brasileira. (FROTA, 1997, p. 37)

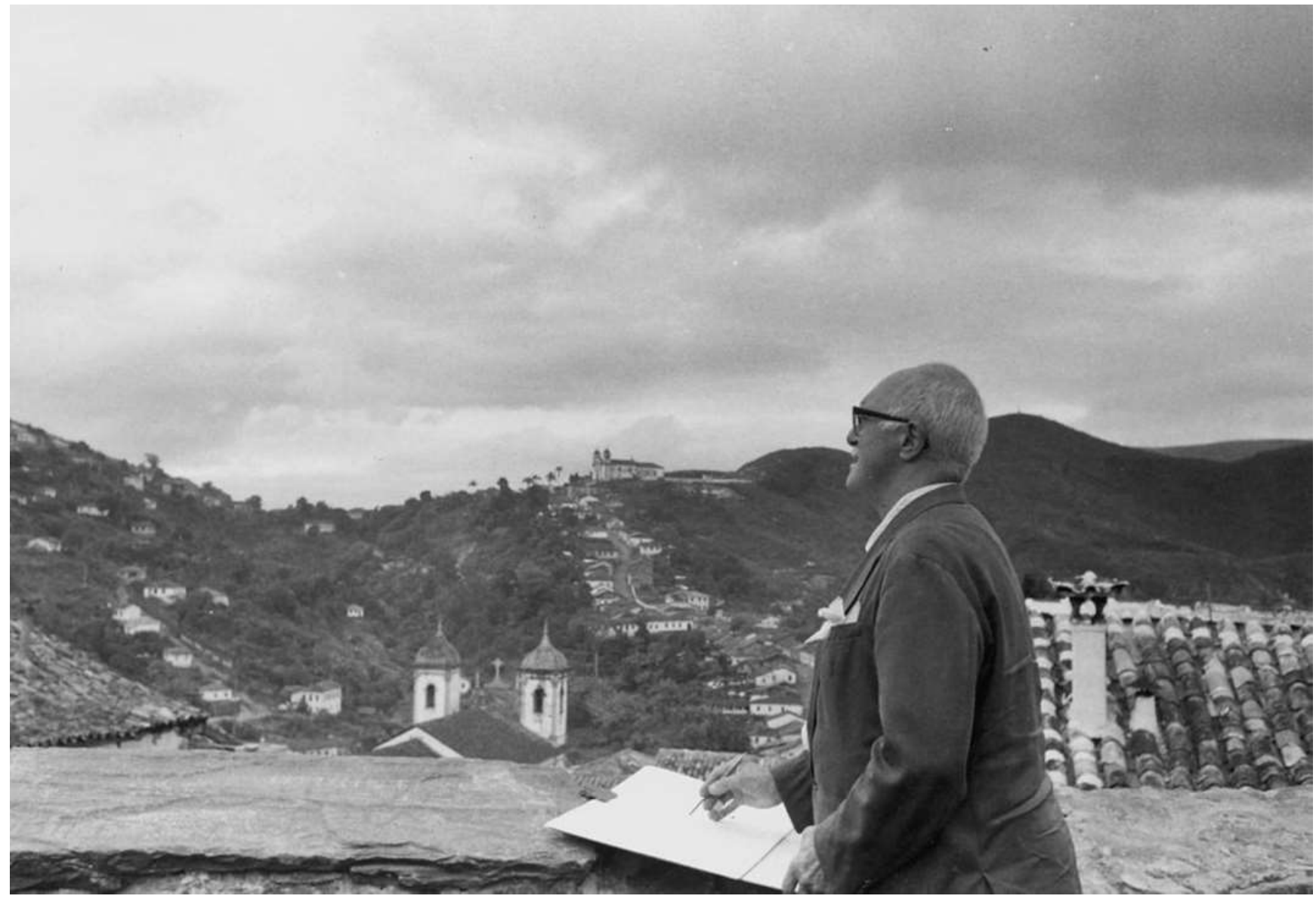


Segundo Sônia Salzstein (1992, p. 16), a originalidade de Guignard pode advir da sua auto-confiança desarmada, o que o faz entregar-se à pintura mais internamente, alheio à ideia do projeto civilizador presente nos anos de Tarsila, por exemplo, alheio à ideia de uma racionalidade construtiva que deveria resgatar positivamente o caos tropical para a construção da nova cultura nacional.

Ao contrário de Tarsila, que foi procurar o Brasil no futuro, na metrópole de São Paulo, Guignard quis apreendê-lo a partir de seu passado mítico, Ouro Preto e Diamantina. Em Tarsila os planos visuais se sobrepõem como esforço de racionalização, vontade de saber, obediência às novas determinações da realidade industrial. Nas noites de São João de Guignard os planos se confundem e distinguem como passe de mágica e sonho. (BRITO, 1983, p. 13)

O relevante em Guignard é a sua atitude moderna, não decorrente de um esforço programático presente na maioria dos modernistas brasileiros, pelo contrário, de uma naturalidade com que sua obra adquire uma espacialidade moderna, talhada no atrito com as condições objetivas de um ambiente cultural como o brasileiro. (SALZSTEIN, 1992, p. 17)

A temática da sua pintura advinha daquilo que encontrava ao seu redor,

Figurou os frutos e os objetos sobre a mesa, as flores junto à varanda, os instrumentos de trabalho em seu ateliê, a música que ouvia, ilustrou poemas que leu, retratou amigos, alunos e a si próprio. Esteve sempre atento à paisagem que o circundava. (MORAIS, 2000, p. 16)

Ele pode ser considerado moderno por seu caráter nacionalista, característica intrínseca ao discurso da arte moderna no Brasil pela busca do que é nativo. Entretanto, conforme Marcos Rodrigues Aulicino (2008, p. 458-59), a solução desenvolvida por Guignard para o tema do nacional revela uma

demarcação muito particular, que não pode ser explorada pela ideologia nacionalista em seus posicionamentos políticos díspares, ao contrário da obra de Portinari que serviu aos interesses dos dois lados do front político, recebendo encomendas oficiais do Estado Novo, e sendo apoiado, ao mesmo tempo, por Mário de Andrade, um dos maiores opositores da ditadura.

Nota-se que a preocupação com o nacional em Guignard vem associada a uma dimensão subjetiva, a qual aparece por meio de elementos singelos advindos do cotidiano do povo brasileiro, representado nos retratos familiares e nas paisagens de Ouro Preto. Tal união foi denominada de "lirismo nacionalista" por Lourival Gomes Machado, primeiro crítico e comentador da obra de Mario de Andrade nos anos 40 e também, grande incentivador da obra de Guignard, "enaltecendo os elementos populares e uma poética que ora tende ao ingênuo, ora à tradição europeia". (AULICINO, 2008, p. 463)

É esse tom lírico que marca a pintura do artista, o qual pode ser associado a produção dos primeiros amigos que fez quando chegou ao Rio de Janeiro, Cícero Dias e Ismael Nery. Ambos relacionados a composições líricas e influências surrealistas, assim como grande parte das obras de Guignard. 
A amizade com Ismael Nery veio primeiro. Guignard ao chegar no Brasil, encontra aqui um ambiente artístico atrasado em relação à Europa. É, justamente, em Ismael Nery, que vê algo diferenciado e atualizado. Ficaram muito amigos e a convivência faz com que Guignard produza obras surrealistas, logo na década de 1930. (FROTA, 1997, p. 35)

Os retratos familiares são quadros com grande valor semântico nacionalista. As pessoas aparecem sempre na posição frontal e a postura delas é como se estivessem posando para uma fotografia, não simplesmente uma fotografia, mas daquela feita em cenários artificiais, cuja caracterização remete às ideias nacionalistas. Cada cenário carrega em si um forte conjunto de significados, desde cada elemento que compõe a paisagem até as vestes dos retratados. (AULICINO, 2008, p. 463)

Há portanto um duplo retrato embutido nesses retratos: a maneira como as pessoas amam fazer-se fotografar, e a pintura de Guignard registrando tudo isso, com o instinto e a profunda solidariedade que tem para com tudo o que faz parte do mundo dado. (FROTA, 1997, p. 56)

Retrato foi o gênero artístico que mais representou dentre suas obras, a isso pode-se relacionar à facilidade que tinha de se aproximar das pessoas, sejam elas quais forem. Não fazia distinção, era uma pessoa muito afetuosa. Em muitos casos, retratava uma pessoa e a presenteava simplesmente por bondade e por prazer em pintar.

Além disso, o artista consegue conciliar a qualidade nacionalista com algo que vem de uma tradição. Mesmo para seus alunos, Guignard procurava evidenciar a importância da relação entre o presente com o passado moderno e tradicional -, para buscar novos caminhos.

Ele não pretendia com essa estratégia que os alunos se voltassem para a cópia do passado, nem que se lançassem na pesquisa dos princípios modernistas sem um embasamento cultural crítico que lhes garantisse a transcendência ao conflito. (VIEIRA, 1988, p. 68)

Como acrescenta Palhares (2010, p. 20),

Seus trabalhos sugerem uma assimilação gradual da linguagem moderna, produzindo assim uma obra na qual parecem se mesclar duas temporalidades, dois espaços, um ainda ligado à tradição e o outro decididamente moderno. Ou, em outras palavras, uma modernidade que é construída por uma via de mão dupla, em que não se nega o passado, mas se procura atualizá-lo, no sentido mais potente da palavra.

A tradição que por parte provém da sua infância, pode ser claramente observada em suas paisagens difusas. Por mais que elas tenham um certo tom onírico, ou ainda, como diz Rodrigo Naves (1996, p. 133), um aspecto lavado, onde o mundo parece prestes a escorrer, como se o víssemos através de uma janela molhada; elas são pontuadas por pequenos ritmos que remontam a elementos presentes quando era criança. São balões, igrejas, pessoas, palmeiras, que se aproximam das recordações de festas juninas, festas de São João. Guignard tinha verdadeira adoração pelas festas de São João, pois lhe vinha à tona a lembrança do aniversário do 
seu pai - homem que tanto admirava -, o qual caía exatamente nesse dia. Para comemorar, seu pai preparava uma queima de fogos de artifício com balões subindo para o céu, uma cena incrível que marcou intensamente a vida daquele menino. "Os balões, na sua obra, são reminiscências do mundo onírico de sua infância. São signos de liberdade, prazer e felicidade perdidos no passado de suas memórias". (VIEIRA, 1988, p. 92)

São as paisagens justamente as obras de maior destaque durante todo o percurso do pintor. E como já se sabe, são as de Ouro Preto que ganham atenção com uma representação singular repleta de apego sentimental, de onde vem o seu lirismo.

O brasileirismo de assunto e sentimento, a visão do homem brasileiro como um ser bondoso e puro, seu encanto pela natureza, a pureza do povo, que ao mesmo tempo se confunde com a pureza do olhar do artista são as notas características do lirismo guignardiano e, diga-se de passagem, sua contribuição à arte brasileira moderna. (PALHARES, 2010, p. 30)

Pode-se falar desse lirismo nacional de Guignard, como uma expressão que vem da alma e não muito preocupada com técnica e teorias artísticas. Segundo Ronaldo Brito (1983, p. 11),

Aí estaria, portanto, um dos marcos do modernismo: assim como Portinari representa a identidade histórica e social brasileira, Guignard exprime a dimensão poética subjetiva. Entre esses dois polos desenhamos ainda hoje o mapa da nossa geografia artística. Um mito objetivo, um mito subjetivo e está pronto o Brasil estético.

Já é sabido que Guignard tinha como ponto de referência a natureza e que gostava de observar e representar a paisagem. Para tal, dava-se bem com as montanhas, pois eram elas que ofereciam cenários deslumbrantes para a composição das paisagens. Especificamente em Ouro Preto, a característica da topografia e a relação com as igrejas em estilo barroco colonial proporcionaram diversas imagens produzidas pelo artista e professor.

Guignard faz de suas paisagens, ou ainda da paisagem de Minas Gerais, um lugar fantasmagórico, pela sua característica difusa e imprecisa. Tal questão, além de ser uma maneira, ainda que inconsciente, de se aproximar daquilo que é onírico, mostra-nos o que aquelas paisagens significavam para ele ao serem representadas. Muitas vezes, sua paisagem vem pontuada por balões, igrejas, caminhos, trens, pessoas, palmeiras, dando a ela certa vivacidade e realçando sua possibilidade justamente pelo distanciamento do observador. "É a esses pequenos seres que cabe conseguir uma caracterização para as paisagens desoladas. Torná-las Ouro Preto e não uma simples região fantasma". (NAVES, 1996, p. 141). Já Sonia Salzstein (1992, p. 18) afirma que esses pequenos seres ou objetos são como que miniaturas, não devido a um apreço ao minucioso ou porque trairiam uma ingenuidade formal, mas para conquistar mais amplidão de vistas para poder pintar o espaço, pura e simplesmente. Essa característica de distanciar os objetos e se focar na paisagem em sua amplitude só reforça que a intenção do artista recaí para o espaço vazio, para o valor formal dado a superfície e, ainda, para uma experiência tomada a distância, onde o campo visual torna-se imenso e cabe a percepção do pintor tomar um ou 
outro caminho diante das inúmeras possibilidades.

Também com relação às paisagens mineiras de Guignard, pode-se ver uma aproximação com a arte oriental a partir de duas características. Uma, por exemplo, "numa ideia de profundidade diferente da perspectiva linear que supõe um ponto privilegiado de fuga, enquanto que a perspectiva oriental é qualificada tanto de aérea quanto de cavaleira" (ZILIO, 1983, p. 20), cujo efeito nos mostra a visão ampla do observador, como citado no parágrafo acima. E outra, marcada pela concepção do espaço através de cheios e vazios.

\begin{abstract}
A pintura oriental é pensada a partir de uma relação entre a montanha e a água, que constituem dois polos entre os quais circula o vazio representado pela nuvem. Esta, por sua vez, é um estado intermediário entre os dois polos aparentemente antinômicos, já que nasce da condensação da água e toma a forma da montanha, e funciona criando um processo de devenir recíproco entre montanha e água. (ZILIO, 1983, p. 20)
\end{abstract}

Pode-se pensar nesses cheios e vazios na obra de Guignard ao ver os elementos que pontuam suas paisagens, por exemplo, as igrejas. Para ir de uma igreja para outra, nosso olhar percorre o vazio entre elas e, assim, percorremos a paisagem toda. Em síntese, a aproximação de Guignard com a arte oriental se dá por aquilo que vem de uma subjetividade.

O próprio tratamento do espaço, a perspectiva contínua, em múltiplos planos, os elementos que se mesclam e que induzem o olhar a explorar a paisagem, não apenas no espaço como também no tempo e que dão o sentido da liberação da imaginação através da natureza e não apenas uma acabada e fechada, são características fundamentais da arte chinesa, ao mesmo tempo que são soluções adotadas, em algumas pinturas, por Guignard. (SCHENKER, 1983, p. 31)

A obra de Guignard apresentava uma característica técnica que estava vinculada ao aspecto inacabado. Talvez por este motivo, não foi uma pintura que teve por parte da crítica de Mário de Andrade o mesmo interesse dedicado a outros pintores.

\title{
Primeiro olhar sobre as paisagens de Guignard
}

A vida conturbada, o defeito e as consequências do lábio leporino, a vida amorosa sem sucesso, o vício de bebidas, a bondade e a ingenuidade ao querer agradar as pessoas a sua volta, a formação acadêmica na Europa, tudo isso contribuiu para o tipo de produção artística que fez, uma pintura difusa, com aspecto sombrio e melancólico adquirido por meio de tons de cinzas, mais próximo de tons escuros e frios e pinceladas soltas.

Mais ainda, na época de contato com Ouro Preto suas obras relevam o encantamento pela cidade e a paixão por representá-la. É na representação da cidade mineira que vemos mais fortemente a relação entre tradição/ modernidade e despojamento em suas pinturas, isso por meio não só de elementos tradicionais que configuram a cidade de Ouro Preto, como as igrejas do período colonial, mas também de tradições advindas da sua infância, como a típica festa de São João e seus balões característicos. 

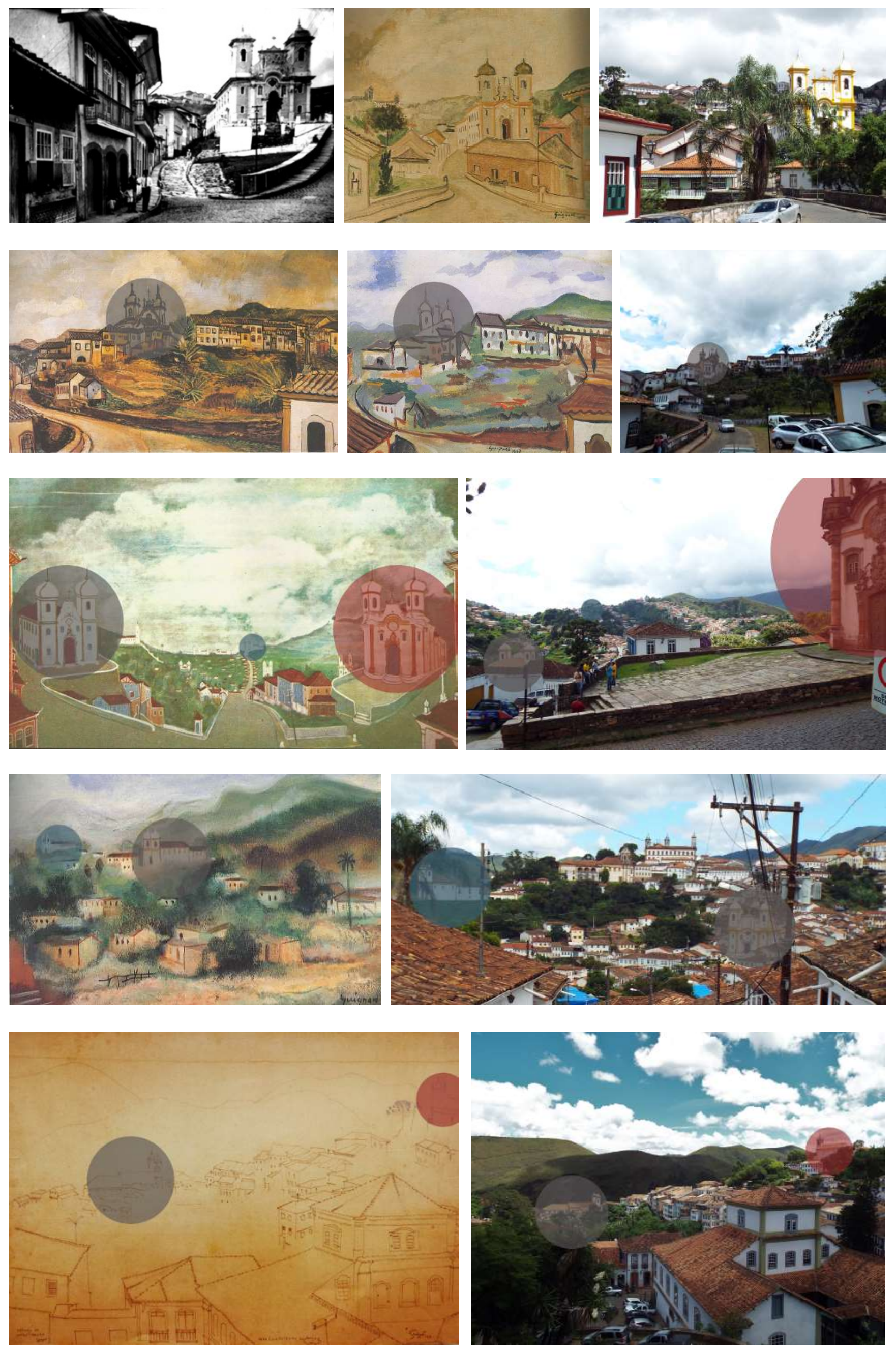
[Figura 15] Paisagem de Ouro Preto, período entre 1923 a 1950. [Fonte] Acervo fotográfico Luiz Fontana, Instituto de Filosofia, Artes e Cultura (IFAC).

Paisagem de Ouro Preto, 1958. [Fonte] Alberto da Veiga Guignard, 1896-1962, 2005.

Fotografia feita pela autora, 2017. Página ao lado.

[Figura 16] Ponte Seca de Ouro Preto, 1946. [Fonte] MUSEU LASAR SEGALL, 1992.

Ponte Seca de Ouro Preto, 1949. [Fonte] MUSEU LASAR SEGALL, 1992.

Fotografia feita pela autora, 2017. Página ao lado.

[Figura 17] Ouro Preto, 1960. [Fonte] MORAIS, 1974.

Fotografia feita pela autora, 2017. Página ao lado.

[Figura 18] Ouro Preto, 1961. [Fonte] MUSEU LASAR SEGALL, 1992.

Fotografia feita pela autora, 2017. Página ao lado.

[Figura 19] Desenho da varanda do Grande Hotel. [Fonte] Fotografia da autora, 2017.

Fotografia feita pela autora, 2017. Página ao lado. autora da pesquisa para Ouro Preto. Além de adquirir fotos da cidade antiga, foram tiradas fotos da cidade atual, tentando captar alguns pontos que foram representados pelo artista em suas obras.

Com isso, foi possível comparar essas imagens e ver o quanto da paisagem real aparece nas representações do artista, identificando o que aparece nas obras, levando em consideração a proporção, a omissão, o acréscimo, ou ainda a posição dos elementos da paisagem.

Pode-se notar que os elementos de destaque nas obras de Guignard são as igrejas, inclusive, ao se observar a paisagem de Ouro Preto é nítido que ela se molda justamente pela configuração das igrejas, as quais delimitam pontos na paisagem. Sendo assim, nessa leitura se demarcou as igrejas e estas foram tomadas como referência para a análise.

Na Figura 15 e 16, é possível ver que tanto a igreja quanto a configuração da cidade ao redor se aproximam muito da realidade, não só a da época de Guignard, mas também da paisagem ouro-pretana que se encontra hoje. Já no caso da Figura 17, as três igrejas estabelecem a mesma relação na representação e na realidade. Guignard consegue captar a relação de posição das igrejas, duas mais próximas e separadas por uma rua bastante acentuada que chega em uma igreja ao longe. Porém, há uma sutileza na pintura, o artista opta por deixar as duas igrejas voltadas para o observador, dá a elas o mesmo peso, uma não se destaca da outra, exatamente pela mesma posição na paisagem, mesmo tamanho e disposição simétrica no campo do quadro.

O reconhecimento das igrejas na obra de Guignard é possível pelo cuidado que o artista tem em representá-las, ou seja, o tipo de torre, a cor dos frisos, a proporção da nave, a quantidade de aberturas, tudo isso mostra ao observador que é aquela e não qualquer igreja. Quando essas características se tornam mais difíceis de observar, é possível reconhecêlas mesmo assim, devido as relações de umas com as outras.

Algumas igrejas são omitidas e também muitas das construções arquitetônicas que configuram a cidade, como observado na Figura 18. A representação não segue de maneira precisa a realidade, a observação do artista se firma naquilo que percebe e, a partir daí, há elementos que chamam mais atenção que outros. A opção pelo que representar diz da experiência perceptiva do artista diante da paisagem que observa. $\mathrm{Na}$ Figura 18, Guignard prendeu seu olhar até as duas igrejas, o que estava para trás delas virou apenas o fundo constituído por montanhas.

Como análise geral dessa leitura, o que se percebe é que, para Guignard, a paisagem de Ouro Preto é conformada pelas igrejas e se caracteriza pela simplicidade entre elas e a topografia montanhosa. Por mais que não se tenha delimitação do que é montanha, somente a posição e tamanho das igrejas já falam da topografia acentuada típica da região. $\mathrm{O}$ artista consegue captar o essencial sem ter que representar, mostrando que os vazios na obra possuem significados e qualificam os cheios, além de ter grande controle quanto a relação de proporção e de distanciamento entre os elementos de destaque, no caso, as igrejas. Uma paisagem tão complexa como a de Ouro preto acaba se tornando simples nos traços desse artista. 

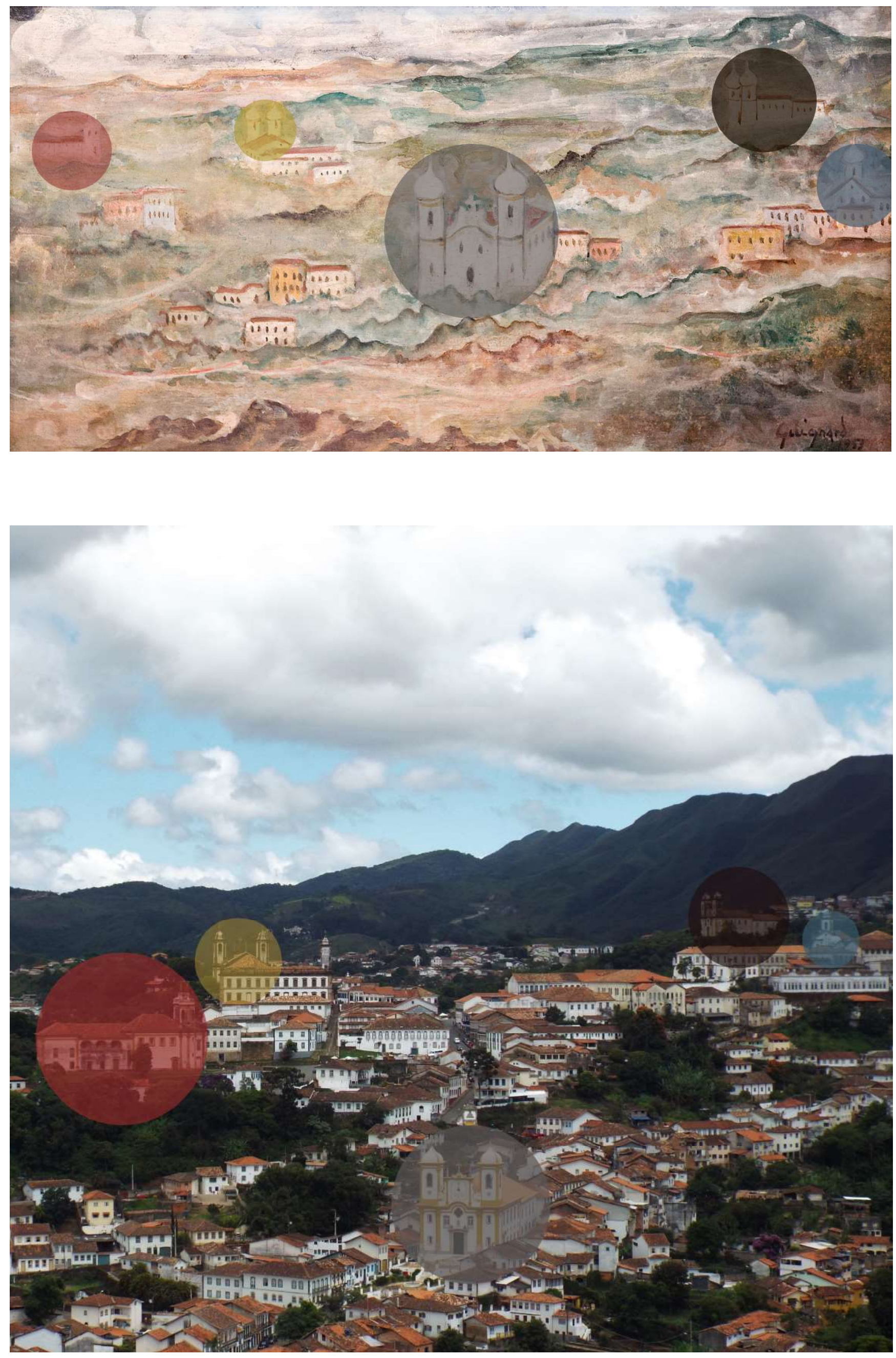
[Figura 20] Sem título, 1953.

[Fonte] Disponível em: http://

www.pinturasemtela.com.br/

alberto-da-veiga-guignarde-sua-passagem-pela-artemoderna/. Acesso em: 25 de julho de 2017. Página ao lado.

[Figura 21] Fotografia feita pela autora, 2017. Página ao lado. 
capítulo II obras 
O percurso de Guignard em Ouro Preto coincide com o percurso de produção das suas pinturas de paisagem. Diante de uma observação mais atenta sobre tais obras, torna-se possível encontrar outras relações não óbvias e levantar novas questões para esse estudo. Lembrando que essa análise se pauta na reflexão de Merleau-Ponty de que a pintura é o meio mais eficaz de redescobrir o mundo da percepção. A análise das paisagens feita na presente pesquisa perpassa mais de duas décadas de produção do artista, começando em 1939, quando ainda não vivia em Ouro Preto, até 1961, ano antes de sua morte. De uma maneira geral, essa análise pode ser dividida em três fases: a primeira que corresponde às primeiras paisagens, de 1939 a 1943, com uma obra mais descritiva (discutida no tópico Representação); a segunda, às paisagens pós 1943 até 1961, com uma obra mais próxima da experiência com o lugar (Experiência); e [Apêndice 1] Linha do tempo a terceira, às demais paisagens de 1961, com uma obra mais relativa à das obras de Guignard 110 memória e aos sonhos (Imaginação). elaborada pela autora, 2017. 


\section{Representação}

$\mathrm{Na}$ primeira fase, as paisagens claramente se diferem das demais. Com uma certa rigidez, o que se destaca, de início, é a composição do campo plástico das paisagens, a qual é dividida em três partes: a superior, com o céu; a central, com o relevo e a inferior, com os elementos arquitetônicos (Figura 23, 24 e 25). É possível perceber a nítida separação entre o que está no primeiro plano - a cidade construída, em especial composta por casas e igrejas - e o que está no segundo plano - a topografia montanhosa. Há ainda uma distinção entre o relevo e o céu - segundo e terceiro plano -, marcando o horizonte. Essas demarcações chamam bastante a atenção, pois se associam com a representação mais próxima ao modelo academicista, por exemplo com a produção das litografias para o livro Voyage Pittoresque dans le Brésil de Rugendas no século XIX, como visto no Capítulo II da Parte I. Vale lembrar que Guignard estudou na Real Academia de Munique, na qual também estudou Rugendas, exatamente um século antes. Nesse sentido, é possível notar ainda na primeira fase uma relação de Guignard com a representação mais formal, que claramente vai se dissolvendo ao longo de sua produção.

Nas litografias de Rugendas, em geral, vê-se a presença de três escalas de tons, por conseguinte, três planos bem demarcados (Figura 22). O primeiro e mais próximo é aquele que qualifica a obra, com uma cena urbana em ação; o segundo corresponde ao que é mais específico quanto a morfologia, quanto a caracterização de determinada paisagem, é, também, a maior semelhança com o desenho feito in loco por Rugendas; e o terceiro mostra

[Figura 22] Villa Ricca, 1835. [Fonte] DIENER; COSTA, 2002. aquilo que se encontra mais distante dos olhos, geralmente são montanhas que quase se esvaem no céu, segundo os princípios da perspectiva aérea renascentista.

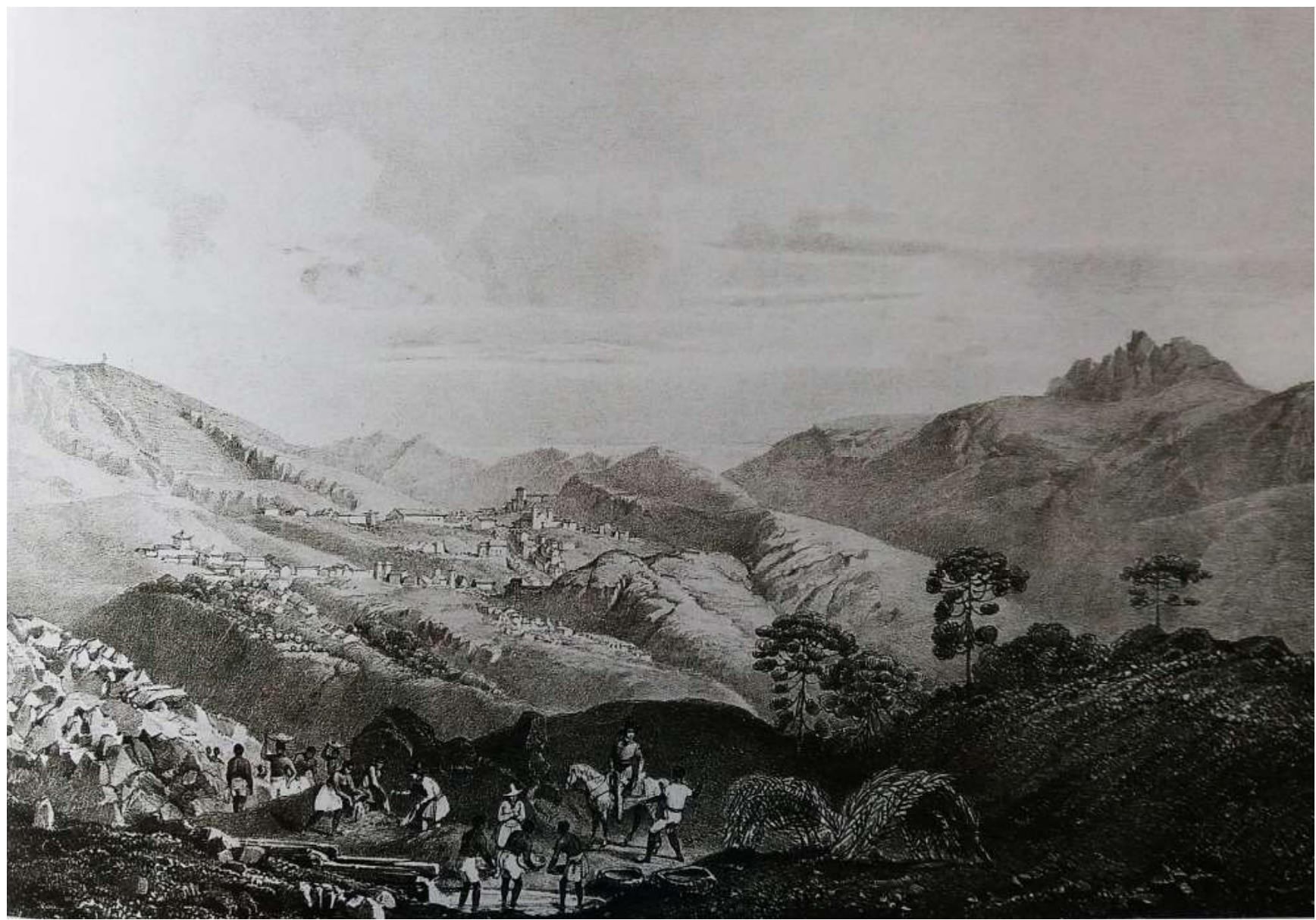


O ponto que contribui para o peso das litografias é a atenção dada ao primeiro plano, a qual se dá por meio da tonalidade mais contrastada, da luz e sombra de modo muito mais intenso que os demais planos. De certa maneira, pode-se retirar esse primeiro plano bem estabelecido e, assim tornar a composição muito mais próxima do desenho original do artistaviajante. Como se os litógrafos deixassem claro que esse primeiro plano tão marcado é uma criação dentro da representação de Rugendas sobre a paisagem brasileira. Além de propiciar essa leitura, a delimitação dos planos por meio de escala de tons é um artifício para representar a profundidade, segundo os princípios do Pitoresco

A questão do primeiro plano em Guignard, pode ser pensada da mesma maneira que a obra de Rugendas com os litógrafos: uma criação dentro da representação mais recorrente de Guignard, como se, dentro das paisagens produzidas posteriormente a essa primeira fase, fosse acrescentado um primeiro plano, bastante demarcado e distinto quanto ao modo de representar. Em Guignard, o peso do primeiro plano não se dá por meio da tonalidade, mas sim pelo tipo de pincelada, cautelosa e atenta aos mínimos detalhes, como será mostrado a seguir.

Para embasar essa aproximação, há a colocação de Merleau-Ponty (2004) acerca da diferença entre a pintura clássica e a pintura moderna. Para ele, pintura clássica consiste mais em uma tentativa de reprodução do real, a mais próxima possível e, para tal, o pintor se utiliza de técnicas ilusionistas para conseguir esse feito. Nesse sentido, ao ter que seguir as técnicas no momento de pintar, o artista deixa de perceber livremente em prol de um padrão a ser transportado para o quadro, aproximação com a produção de Rugendas com o uso de técnicas empregadas com base no modelo de apreciação europeu da época e, em partes, com a produção de Guignard nessa primeira fase. Enquanto que, a pintura moderna não se baseia em tentar imitar o real, mas sim em deixar a própria manifestação do contato com o mundo acontecer. Essa pintura pode até se aproximar a um desenho infantil, pois, da mesma maneira, é uma percepção que não distingue claramente o real do imaginário e, nesse caso, o pintor possui uma maior liberdade ao se expressar, incorporando o que acha relevante, aquilo que sente e que vem de seu interior, como é a pintura de Guignard em geral, a maneira livre de representar é fortemente notada nas suas obras.

Quanto a divisão do campo plástico nas obras da primeira fase de Guignard, no primeiro plano nota-se a riqueza de pormenores e o cuidado do artista em evidenciar ao máximo aquilo que caracteriza cada edifício. Cada detalhe arquitetônico construído com cautela, bem como a escolha das cores, deixa a representação próxima da realidade. As edificações recebem traços precisos em coloração branca para ressaltar as molduras salientes nas portas e janelas e as eiras e beiras da fachada, características presentes na arquitetura colonial. Ao mesmo tempo, há componentes que a distanciam da realidade, por exemplo advindos do estranhamento da perspectiva, a sobreposição de umas e outras edificações e as linhas paralelas em diagonais com diferentes angulações, claramente evidenciada na Figura 23, distorcem a perspectiva. Não que isso seja um erro de Guignard - já é sabido do seu potencial como artista e do seu aprendizado baseado nas tradições acadêmicas clássicas do Renascimento, berço da perspectiva-, mas sim proposital a ponto de passar ao observador um ar inocente, ingênuo, beirando as representações infantis e, até mesmo, uma arte naïf.
[Figura 23] Três planos. Paisagem Imaginante, 1943, $41 \times 33 \mathrm{~cm}$

[Fonte] FROTA, 1997. Página ao lado.

[Figura 24] Três planos. Paisagem Imaginante, 1939, $55 \times 80 \mathrm{~cm}$.

[Fonte] FROTA, 1997. Página ao lado.

[Figura 25] Três planos. Paisagem Imaginante, 1942, $80 \times 60 \mathrm{~cm}$.

[Fonte] FROTA, 1997. Página ao lado. 

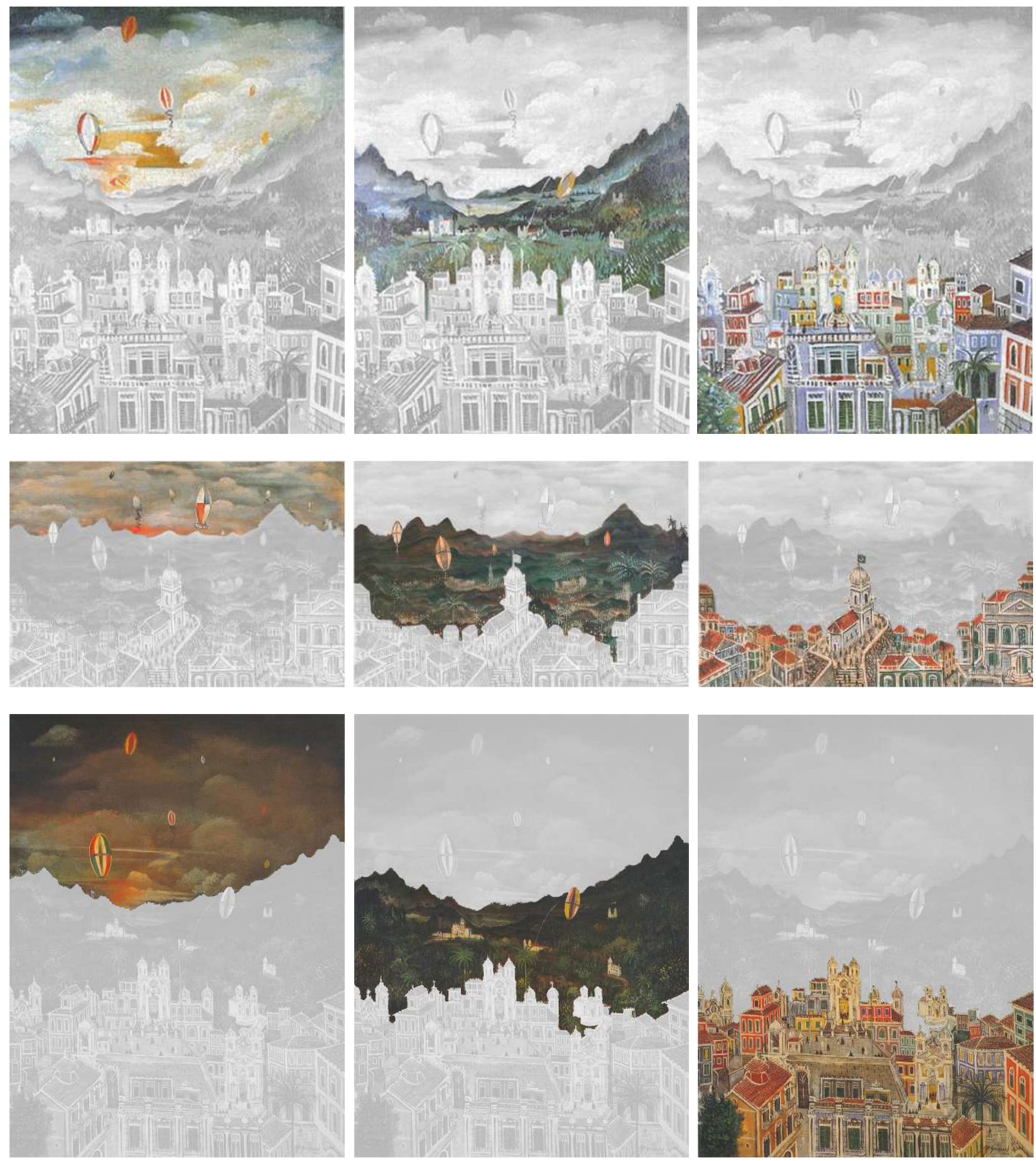

Nessas obras, em geral, aparecem pessoas, as quais dão vivacidade a paisagem mineira, mesmo estando em escala reduzida. A constituição de uma cena urbana, conseguida por esses pequenos pontos - e também pelos balões de São João e pela paleta de cores utilizada -, dá um tom alegre, um tom de vida para a paisagem, característica que parece se alterar nas obras mais para o fim de sua produção.

No segundo plano também há um cuidado. Por mais que as pinceladas pareçam soltas, elas são executadas de maneira minuciosa, seguem o movimento das montanhas e possuem um ritmo, caracterizando os pontos mais altos e mais baixos, a presença de vegetação e, ainda, de algumas edificações. O grande destaque aí se dá pelo jogo de claro e escuro em consonância com o que se encontra mais elevado ou mais baixo e em maior ou menor destaque na paisagem. $\mathrm{O}$ tom que predomina no 
plano montanhoso é o esverdeado, mais carregado para o tom escuro, juntamente com pigmentação marrom e preta, acentuando o eixo descritivo dessas paisagens. Por mais que em algumas paisagens o tom esverdeado não predomine, ele aparece de forma sutil, como é o caso das paisagens da Figura 26. A paleta de destaque nos quadros vem também de uma cor fria, a azul, e se mescla, em partes, com um azul um pouco esverdeado e com pequenas pinceladas de um marrom avermelhado, aproximando-se do aspecto terroso do relevo.
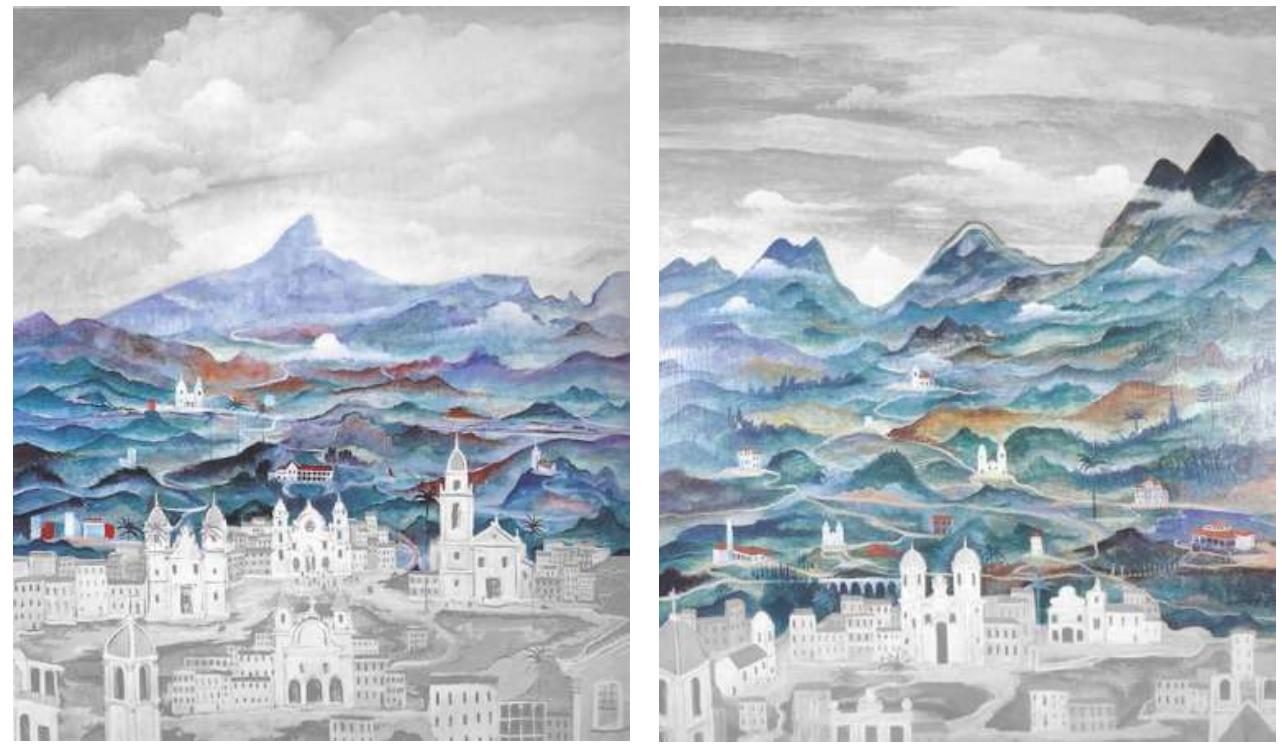

As paisagens de 1941 ainda se diferem um pouco quanto a representação do primeiro plano (Figura 27). As edificações aqui não recebem os traços detalhados e de contorno, o que se vê é uma forma limpa e clara, correspondente à fachada, e pontos menores, escuros, às aberturas. As cores não são vivas, tampouco queimadas, são cores claras, esbranquiçadas, que amenizam esse primeiro plano e possibilitam um maior equilíbrio com o restante do quadro.

A distinção entre o segundo e o terceiro plano é conseguida pela diferença de cores e/ou pelo tipo de pincelada. Quando a tonalidade das montanhas e do céu é a mesma, como a azulada na Figura 26, o destaque se dá pela pincelada, feita em forma mais circular para caracterizar as nuvens e mais retilínea para o fundo do céu; já quando a tonalidade entre montanhas e céu se diferem consideravelmente, Figuras 23, 24 e 25, o recurso mais

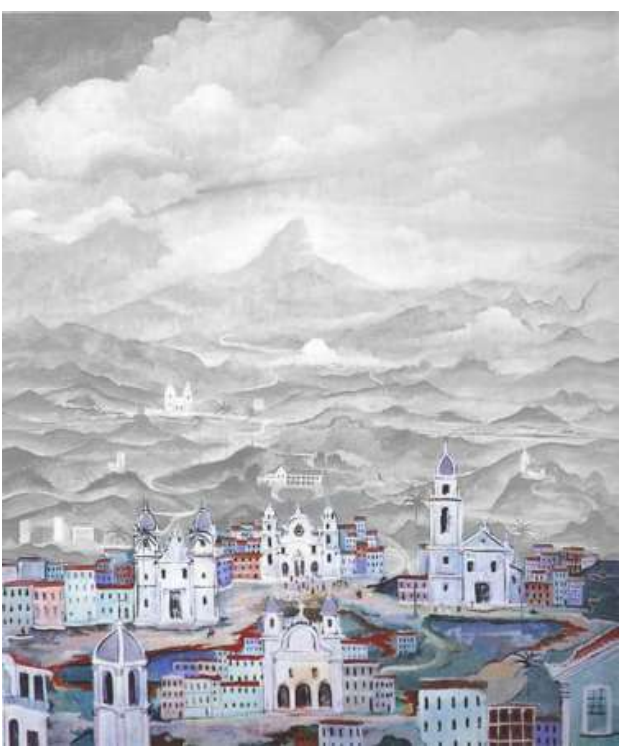

[Figura 26] Segundo plano em destaque. Paisagens Imaginantes, 1941, $150 \mathrm{x}$ $100 \mathrm{~cm}$.

[Fonte] FROTA, 1997.
[Figura 27] Primeiro plano em destaque. Paisagens Imaginantes, 1941, $150 \mathrm{x}$ $100 \mathrm{~cm}$.

[Fonte] FROTA, 1997. 
[Figura 28] Paisagem sem o primeiro plano. Paisagem Imaginante, $1939,55 \times 80 \mathrm{~cm}$. [Fonte] FROTA, 1997. utilizado é mesmo o da cor, embora ainda se consiga perceber umas pinceladas mais circulares e esbranquiçadas. $O$ aspecto esbranquiçado é muito recorrente nas paisagens ouro-pretanas de Guignard, não somente no terceiro plano quando representa as nuvens no céu, como também no segundo plano ao representar a névoa que paira nas regiões mais baixas do relevo, em menor ou maior destaque dependendo da paisagem.

Pelas cores utilizadas para representar o céu, não se consegue ter certeza se Guignard pintou durante o dia ou a noite. Quando tende a parecer dia devido aos tons mais claros, há um ponto mais escuro no céu que tende a caracterizar a noite. Nesse jogo de pontos claros e escuros, com pinceladas esbranquiçadas - ora parecendo nuvens num dia nublado, ora fumaça que paira sobre a noite - e com pinceladas em cores quentes - assemelhando ao sol ou então a um clarão relacionado a fogo, como se viesse de uma fogueira de festa de São João - o dia e a noite se confundem. Essa será uma questão que permanecerá nas paisagens de Guignard, algumas vezes até se aproximando de uma certeza, mas, em geral, causando mais dúvida do que nas paisagens vistas até aqui, principalmente nas obras da última fase da vida do artista.

O peso do quadro se concentra no primeiro plano na parte inferior, visto que a quantidade de elementos arquitetônicos preenche praticamente todo o espaço e, mais do que isso, para conseguir a riqueza de detalhes, tais elementos precisam ter uma certa escala, o que se percebe uma maior aproximação do artista com a paisagem. Ao estar mais próximo dos elementos urbanos, consegue apreender os detalhes de maneira mais nítida e, com isso, o primeiro plano salta aos olhos. O mesmo não acontece nas demais fases, pelo contrário, o artista se distancia do lugar e amplia sua tomada de visão, passa a se apegar às relações mais amplas da paisagem do que se prender às minúcias de uma representação descritiva, não existindo mais o primeiro plano, somente o que corresponde ao segundo e terceiro planos aqui colocados. Em outras palavras, se o primeiro plano das paisagens dessa fase for retirado, elas passam a se assemelhar às demais obras no que diz respeito a uma certa espacialidade, as ondulações do relevo ganham peso e os pontos demarcados por igrejas, balões, palmeiras ocupam o campo plástico de maneira dispersa (Figura 28 e 29).

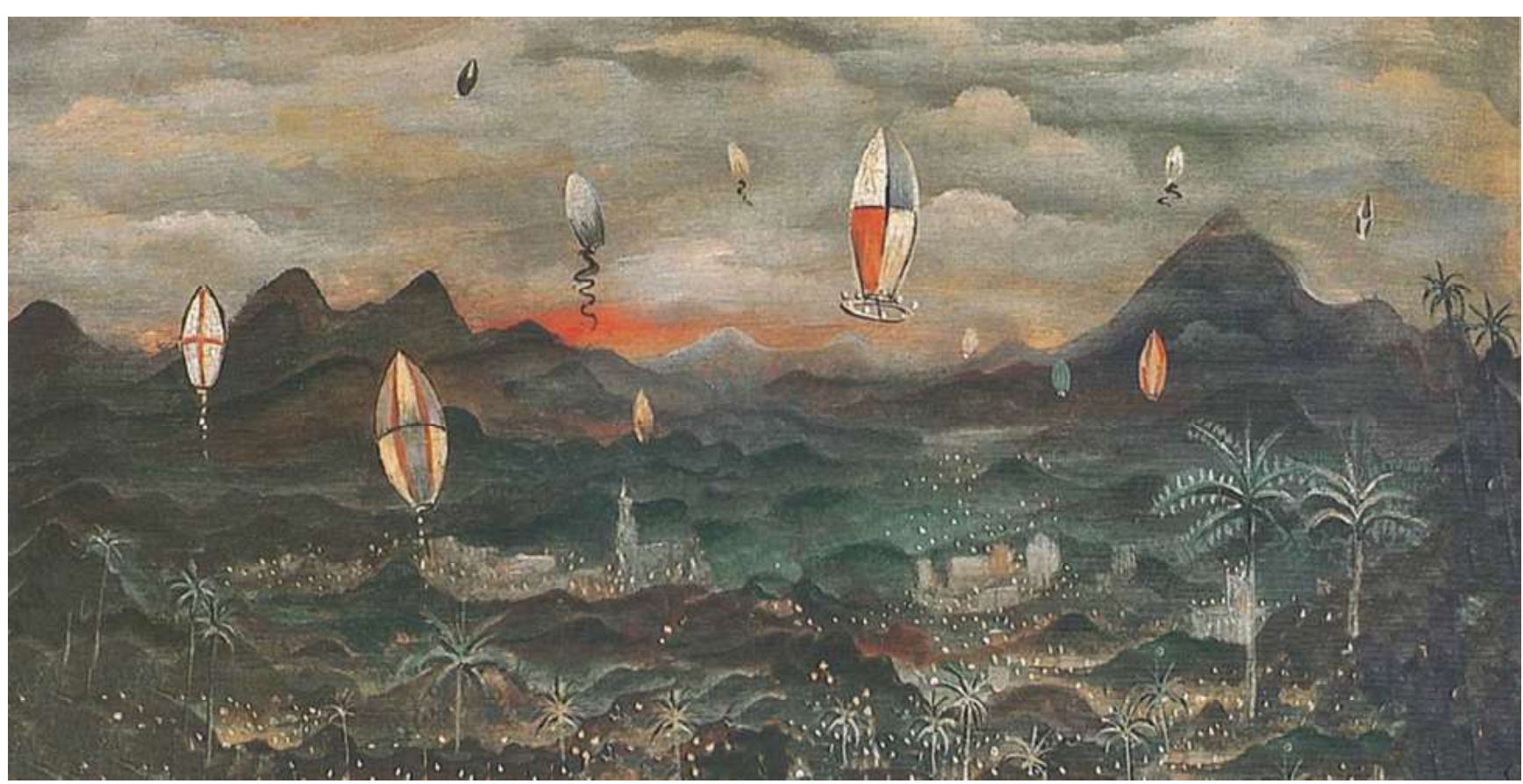



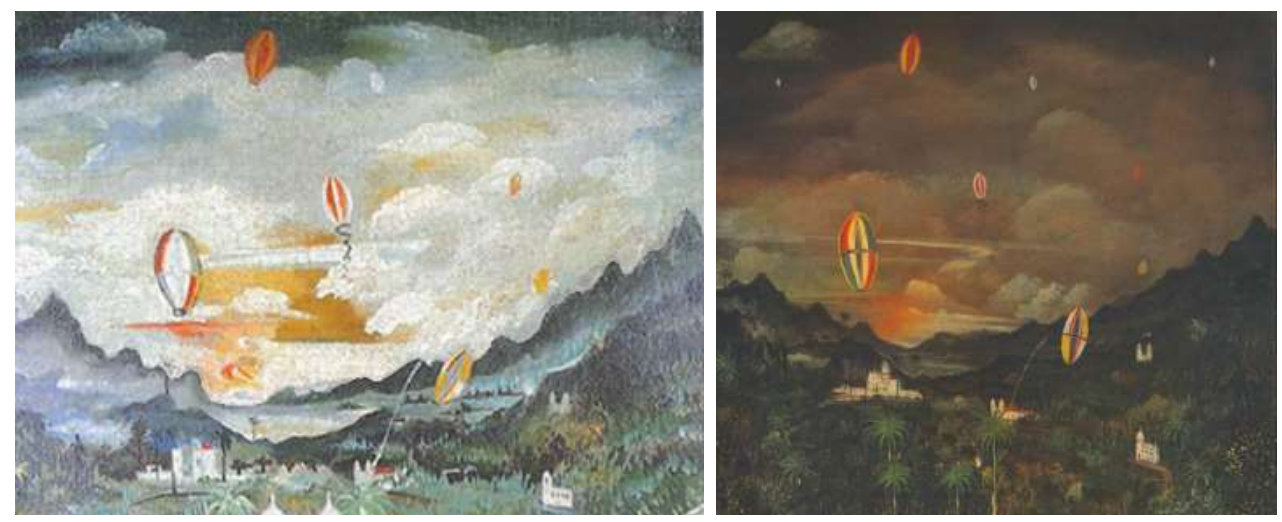

Mesmo tendo semelhança com as demais obras, não se pode descartar o caráter descritivo dessas paisagens. O primeiro plano era, de fato, 0 mais preocupado com uma descrição minuciosa - devido à proximidade do artista e à escala, como já foi dito -, mas tanto o fundo do quadro, relevo e céu, quanto os elementos pontuados, são executados com uma maior precisão. As linhas onduladas do relevo são marcadas e evidenciam sua forma. As pinceladas e cores do céu as distinguem do restante do quadro, os balões não são borrões no ar, possuem um contorno definido e uma divisão simétrica quanto a estampa colorida e as edificações religiosas pontuadas nos cumes do relevo, essas sim se assemelham com as demais, com pinceladas mais soltas e com menos detalhes, configuram o que é mais essencial: forma, proporção e posição no espaço.

Além das paisagens, para essa análise é válido considerar alguns retratos produzidos por Guignard, visto que eles possuem a paisagem ouro-pretana ao fundo. Pode-se dizer que o retrato é uma representação de paisagem com uma pessoa evidenciada no primeiro plano e, da mesma maneira que as pinturas de paisagem são distintas ao longo do percurso do artista, os retratos também. Os retratos se enquadram na divisão das paisagens feita nesse estudo. Dentro dessa primeira fase há um retrato de 1940 (Figura 30 ), cujas características da paisagem ao fundo se assemelha às paisagens produzidas por Guignard nesse período.

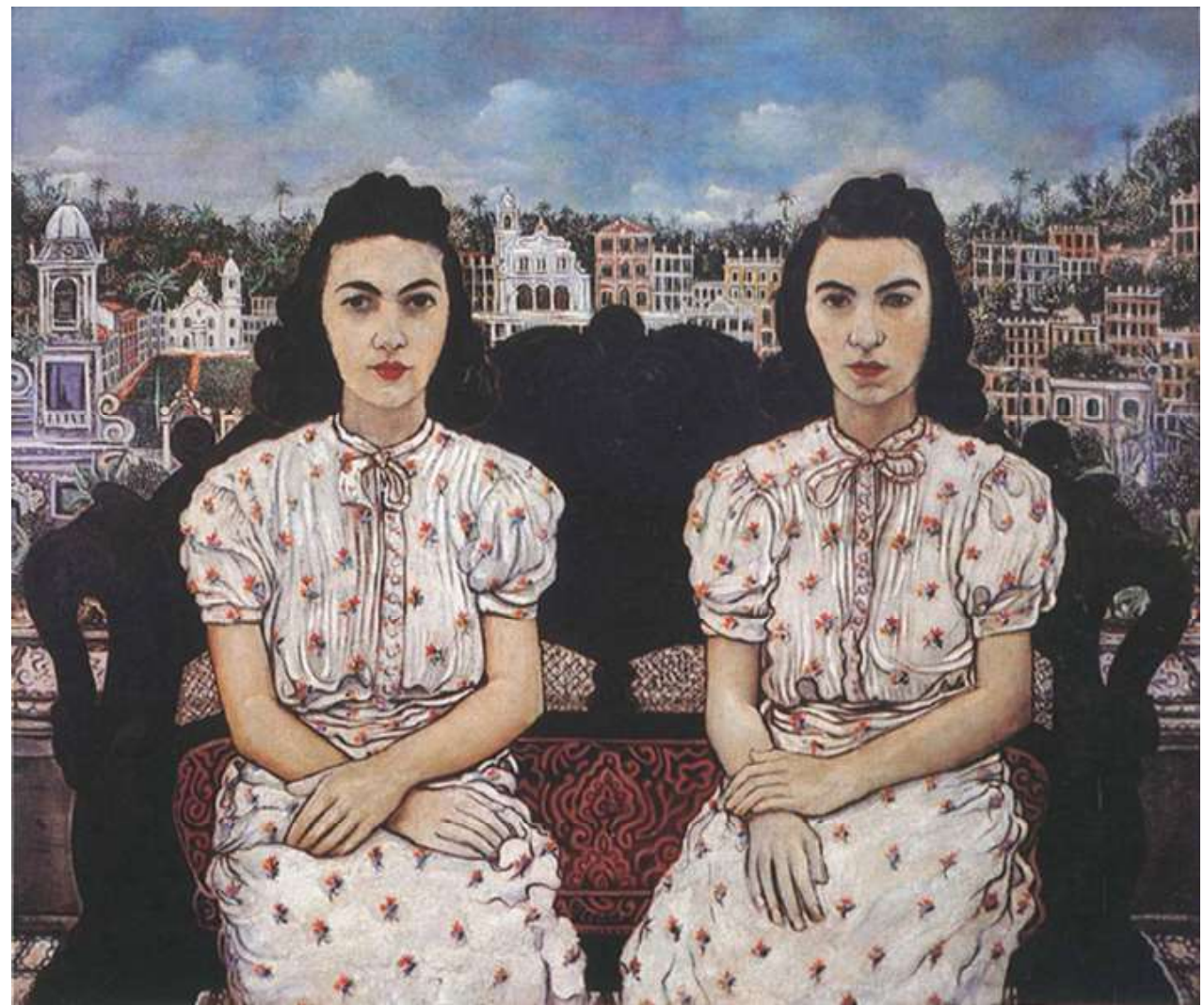

[Figura 29] Paisagem sem o primeiro plano. Paisagem Imaginante, 1943, 41 x 33cm e Paisagem Imaginante, 1942, $80 \times 60 \mathrm{~cm}$.

[Fonte] FROTA, 1997.
[Figura 30] As gemeas Lea e Maura, 1940, $110 \times 130 \mathrm{~cm}$. [Fonte] FROTA, 1997. 
Enquanto que as paisagens aparecem com três planos definidos, sendo o primeiro plano marcado pelas construções arquitetônicas, o retrato da Figura 30 ainda se atém a essa configuração, no entanto, aos três planos estruturadores da paisagem é acrescentado um plano a frente com a figura humana, o qual passa a ser o primeiro. Nesse sentido, os planos da paisagem ao fundo passam a ser segundo, terceiro e quarto, respectivamente.

$O$ retrato nessa fase também se caracteriza por ser mais descritivo, o cuidado do artista com os pormenores das edificações com traços bem definidos é aplicado na representação das pessoas. Esse cuidado é percebido no detalhamento das vestimentas, nas minúcias da estampa e no caimento do tecido, revelando a textura e a leveza dele. A paleta de tons claros, tanto para as gêmeas quanto para a paisagem mostra, mais uma vez, a relação entre elas, como se a característica, o comportamento e o estado de espírito das irmãs fossem rebatidos na representação da paisagem, nesse caso, uma paisagem clara com cores amenas, passando uma certa calma, tranquilidade e, até mesmo, uma timidez, que parecem caracterizar as gêmeas.

A cor escura do móvel em que estão sentadas contrasta ainda mais o primeiro e o segundo plano claros. É responsável por modelar as figuras humanas a ponto de evidenciá-las no quadro.

O período de produção das obras dessa primeira fase coincide com o acontecimento da vida do artista. Foi em 1944 que Guignard se mudou para Minas Gerais, a princípio para Belo Horizonte, a pedido do então prefeito Juscelino Kubitschek. No entanto, a partir disso começou a manter relação estrita com Ouro Preto, chamada por ele de amor-inspiração. Antes de tal período, Guignard não tinha contato com a cidade, apenas tinha conhecido e ido algumas vezes, justamente quando pintou as paisagens dessa fase. Com isso, pode-se dizer que nessa primeira fase a relação entre quem observa e quem é observado ainda é de descoberta, de contato inicial com o desconhecido, de vislumbre com as particularidades e de busca para captar ao máximo o que se percebe desse objeto tão cheio de detalhes que é a cidade de Ouro Preto.

Experiência

Depois de anos vivenciando a cidade e a representando de modo mais cuidadoso, Guignard adquire um repertório de experiência bastante amplo e é, a partir daí que produz as paisagens da segunda fase. Passa a ter um olhar mais aproximado, de pertencimento, de relação mais íntima com aquela que antes era desconhecida e cuja a relação ocorria à distância. São paisagens que mostram a Ouro Preto de sua época, não simplesmente como uma tentativa de cópia fiel da realidade, como na primeira fase, mas sim a Ouro Preto do próprio pintor, baseada nesse repertório já adquirido. Acresce à paisagem mineira um tom lírico, uma liberdade expressiva que abarca características advindas de uma tradição relacionada a infância, como já dito, e juntamente associada a um caráter onírico e imaginativo, que será cada vez mais evidente.

A segunda fase da análise abrange as demais obras até parte das obras do ano anterior a morte do pintor. A escolha por essa divisão se deu pelo primeiro olhar atento sobre a cronologia das paisagens, pela semelhança mais evidente encontrada entre as paisagens, no caso, a composição do campo plástico. Ao observar as paisagens dispostas em ordem cronológica, 
salta aos olhos a diferença entre a composição com três planos claramente delimitados e com peso maior para o inferior, como já citado na primeira fase, e a composição não delimitada, onde os três assuntos dos planos se mesclam e não se consegue inferir uma maneira única de sintetizar o quadro. O que se tem é uma rigidez modulada, característica da primeira fase, em contraposição a uma diluição dos limites entre os elementos representados, céu-topografia-arquitetura.

Um olhar mais atento permitiu desvelar particularidades da segunda fase. Ainda no final da década de 1940, pode-se notar uma separação entre relevo e céu, no entanto, os elementos arquitetônicos já se dispõem de modo mais solto pelo quadro. A partir de 1950, cada vez mais o tipo de pincelada e a tonalidade de cores, tanto para a topografia montanhosa quanto para o céu e as nuvens, aproximam-se a ponto de se mesclarem e se confundirem um com o outro. Em grande parte das paisagens o céu acaba sendo uma extensão do relevo, no entanto, pode aparecer ainda uma leve distinção entre eles, o artista parte de um mesmo fundo - as vezes com tom distinto na parte superior ao restante da tela - e acrescenta pinceladas mais escuras, em geral para representar os cumes das montanhas, e pinceladas esbranquiçadas, para a névoa nos vales do relevo e para as nuvens. Inclusive essa característica até se assemelha com as paisagens da primeira fase, afinal foram produzidas pela mesma mão, todavia aqui, aparecem de forma amena, deixando a diferença entre terra e ar pouco perceptível ou mesmo imperceptível.

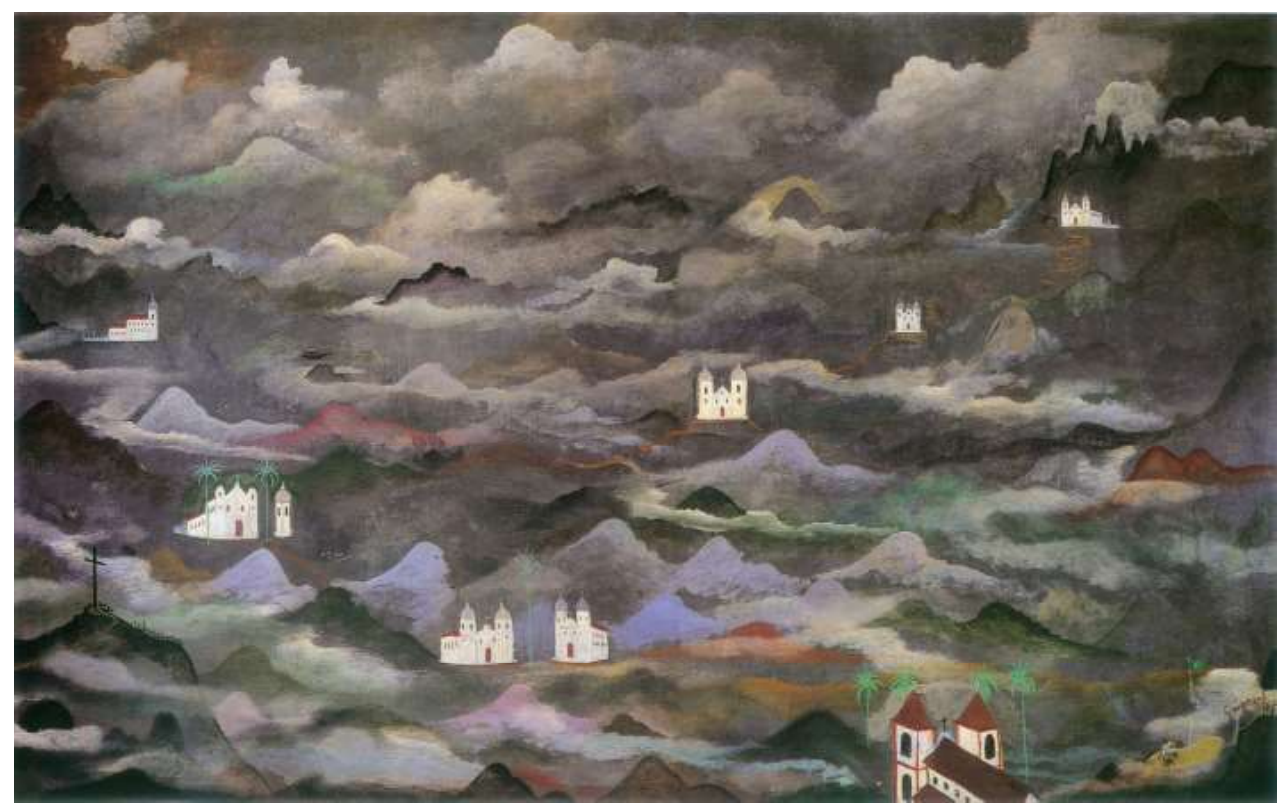

[Figura 31] Paisagem Imaginante, 1950, $80 \times 110 \mathrm{~cm}$. [Fonte] FROTA, 1997.
Nessa fase, outra grande diferença é em relação ao posicionamento das igrejas. Se antes as edificações se aglomeravam na parte inferior do quadro, agora elas se dispõem de forma pontuada por toda a paisagem. Há uma paisagem em 1947, Figura 32, que ainda guarda essa característica da primeira fase, porém as edificações se aglomeram no centro e vão se dispersando no restante do quadro. Pode-se perceber que é uma gradação entre a configuração da cidade que de início chamou a atenção de Guignard, para como ela foi se mostrando para ele.

Ao se falar no gênero paisagem, pensa-se de imediato uma relação de horizontalidade, inclusive a orientação da tela na horizontal é denominada de modo paisagem, enquanto que na vertical, modo retrato. Nesse sentido, há uma questão curiosa nas pinturas de Guignard: a maioria das 
[Figura 32] Edificações em destaque. Noite de São João, 1942, 80 x 60cm; Paisagem, $1947,158 \times 208 \mathrm{~cm}$ e São João, 1959, $38.5 \times 29 \mathrm{~cm}$. [Fonte] FROTA, 1997.

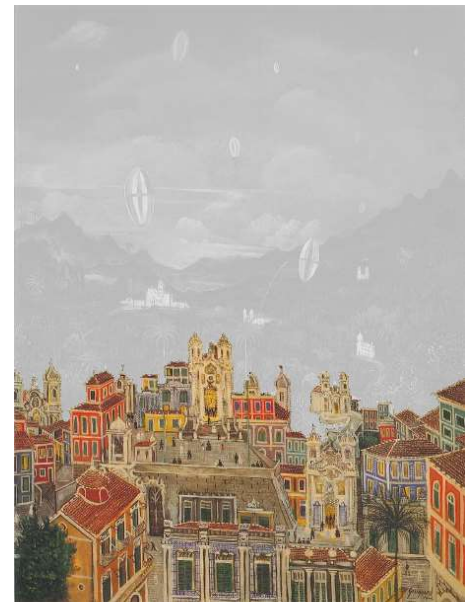

[Figura 33] Elementos em destaque. São João, 1961, $61 \times 46 \mathrm{~cm}$. [Fonte] Alberto da Veiga Guignard, 1896-1962, 2005; Paisagem Imaginante, 1955, $95 \times 78 \mathrm{~cm}$. [Fonte] FROTA, 1997 e Balõezinhos, sem data, 29,5 x 47cm. [Fonte] Um mundo a perder de vista: Guignard, 2008.

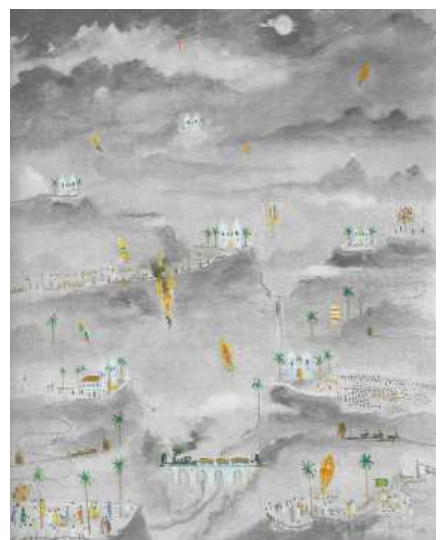

das paisagens presentes nesse estudo são em modo paisagem. Isso tem relação com a maneira com que o artista se relaciona com a paisagem mineira, por mais que a grandiosidade da extensão montanhosa de Minas Gerais possa parecer o tema de destaque, Guignard a reverte e mostra a relação vertical com mais força e, a partir disso, passa a aproximar não só o ritmo das montanhas com o céu, de forma a se fundirem, como também, é possível pensar na relação entre as igrejas e o céu, naquilo que é divino, numa aproximação ao campo etéreo e ao tom onírico de suas paisagens.

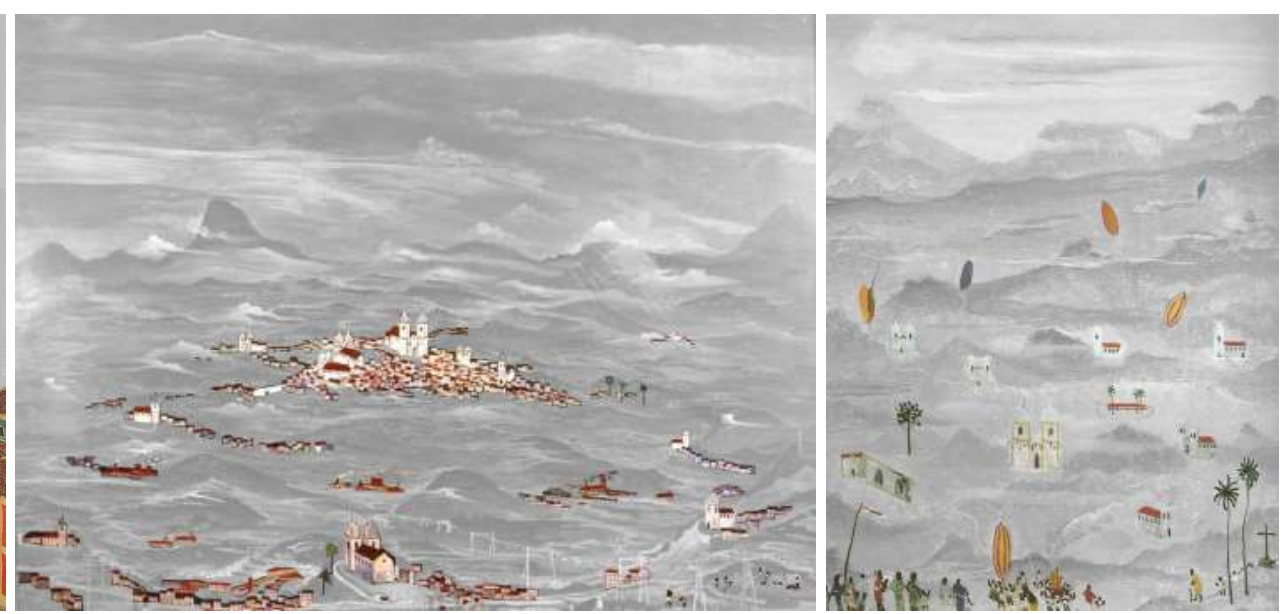

As obras passam de um apego à descrição e aos detalhes para uma relação mais livre entre a paisagem e o artista. Nessa fase, tal liberdade é observada nos tipos de pinceladas e disposição dos elementos no campo plástico. A composição não delimitada, citada acima, já mostra a liberdade que está por vir nas pinceladas, ela é livre quanto à disposição das igrejas, quanto à distinção entre céu e terra, quanto ao ponto de destaque do quadro. Sem ter um modo fixo de representar, Guignard deixa a paisagem se mostrar para ele e em cada quadro ela tem algo diferente a mostrar. É possível dizer isso porque enquanto a primeira fase nos mostrava uma leitura única para todas as paisagens, sem acrescentar muita descoberta quanto à composição, a segunda fase não tem essa preocupação. Além disso, aqui as pinceladas configuram o essencial, aquilo que chamou a atenção do pintor e que, sem precisar descrever os detalhes numa observação obcecada, os elementos do lugar observado toca a sensibilidade do artista e o afeta na amplitude da paisagem.

O que se percebe na segunda fase é uma atenção voltada para as igrejas que pontuam a paisagem no meio das pinceladas difusas e para os demais elementos destacados nela, como as casas, palmeiras, pessoas, balões (Figura 33).
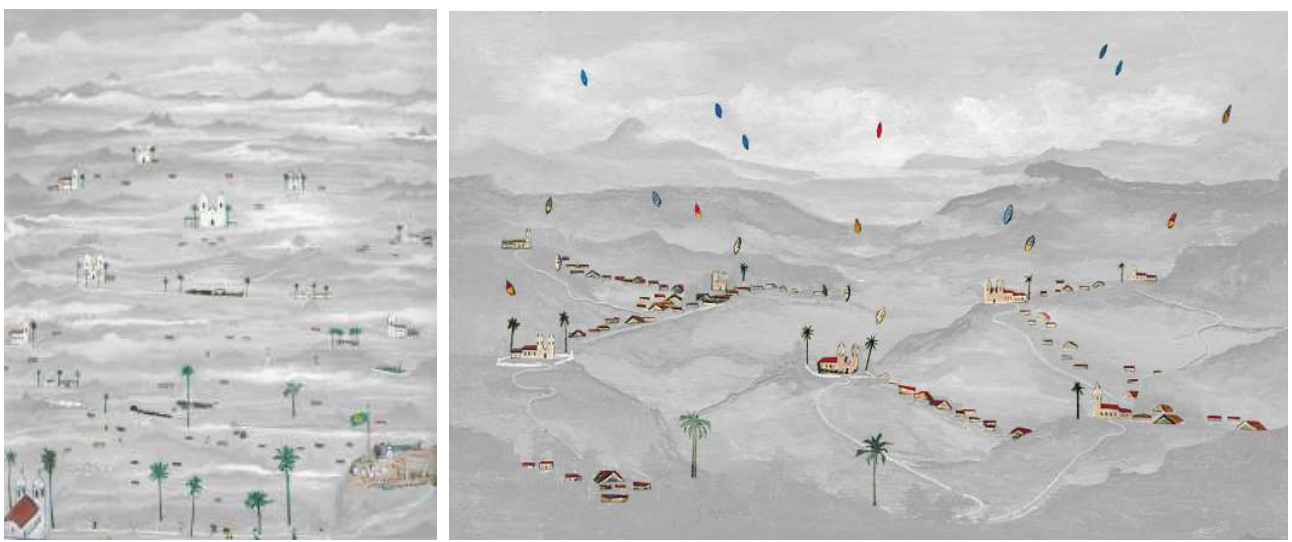
Ao observar as construções religiosas, nota-se a importância delas na paisagem para o artista e como elas configuram o espaço como um todo. Estão dispostas nos pontos mais altos das montanhas e variam quanto a posição no campo plástico. A importância das igrejas não se dá apenas por elas mesmas, os elementos que as rodeiam dão significados distintos para a paisagem, ora as igrejas aparentam estar em um momento de ascensão juntamente com os balões, ora mais cravadas no solo com as pessoas no chão e com a ponte.

De um modo geral, nosso olhar percorre o quadro partindo da igreja de maior destaque e vai contornando a paisagem, obedecendo a sequência de igrejas marcadas e completando a volta toda até retornar ao ponto de partida. Nesse sentido, é possível criar uma forma adquirida pela união dos pontos, numa espécie de área de influência das construções religiosas na paisagem, reforçando o caminho do nosso olhar no campo da pintura (Figura 34).
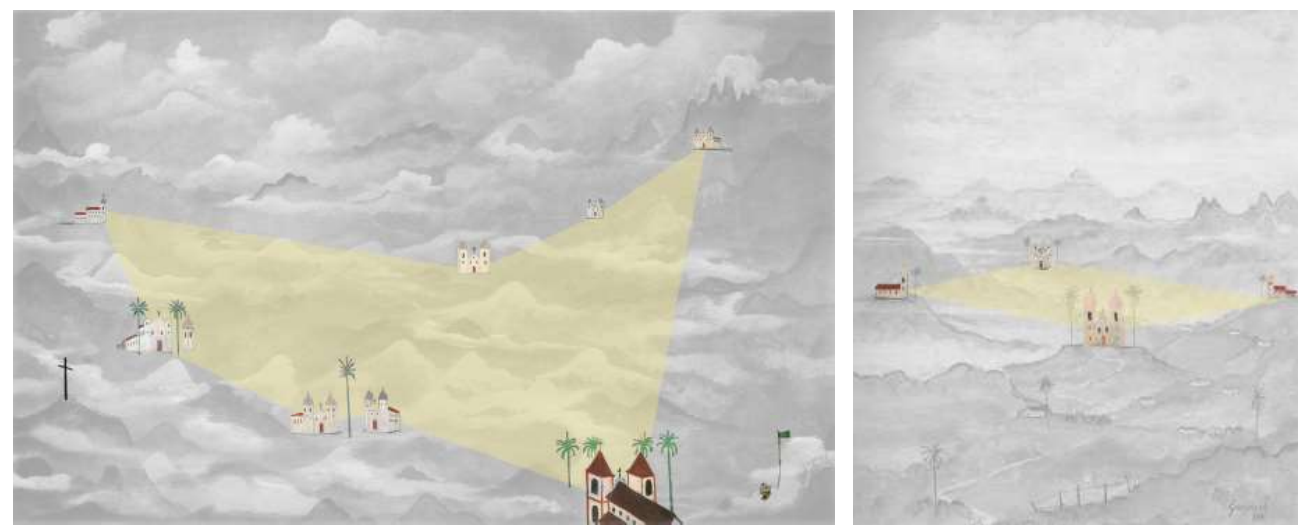

Os elementos, que formam sequências lineares ou que estão próximos das igrejas, ajudam a unir esses pontos, facilitam o caminho a ser seguido. Já os que estão mais distantes, geralmente, preenchem o quadro ou na parte superior, caso dos balões, ou na parte inferior com palmeiras, pessoas, casas. Isso nos leva a percorrer todo o quadro, dando atenção para as minúcias sobre o fundo montanhoso. Em geral, há um equilíbrio entre a parte central, com mais detalhes, e as extremidades inferior e superior mais difusas, ainda com peso maior para o que está fixado no chão, quando o pintor se aproxima da paisagem e nos mostra uma cena urbana. Esta constituída não com um rigor de detalhamento - mesmo porque tais elementos são muito pequenos perto da paisagem que aparece na tela -, mas com poucas pinceladas capazes de nos inferir o que deseja.

Além disso, a distribuição linear dos elementos reforça a ideia de topografia montanhosa, em que o ritmo ondulado demarca os planos provenientes desse relevo, claramente observado na Figura 33. Enquanto que as igrejas, os vértices da forma poligonal, marcam os cumes das montanhas, os elementos ora completam as arestas, ora se espalham, difundindo nosso olhar para outros pontos do quadro e nos desligando do contorno imaginário constituído pela união das igrejas (Figura 34).

Com relação às igrejas pontuadas e à forma gerada pela ligação dos pontos, foi possível notar uma simetria entre elas ao dividir o quadro ao meio, geralmente, no eixo da igreja de maior destaque, que se dá pela centralização na paisagem e/ou pelo seu tamanho ampliado. Quando os dois lados não são exatamente simétricos quanto ao número e posição das igrejas, há um elemento de peso no lugar faltante, possibilitando ao nosso olhar completar a simetria dada.
[Figura 34] Leitura de forma adquirida pela união das igrejas feita pela autora. Paisagem Imaginante, 1950, $80 \times 110 \mathrm{~cm}$.

[Fonte] FROTA, 1997; Paisagem Imaginante, 1961, $50 \times 43 \mathrm{~cm}$. [Fonte] FROTA, 1997; São João, 1961, 55 x $46 \mathrm{~cm}$. [Fonte] Alberto da Veiga Guignard, 1896-1962, 2005.

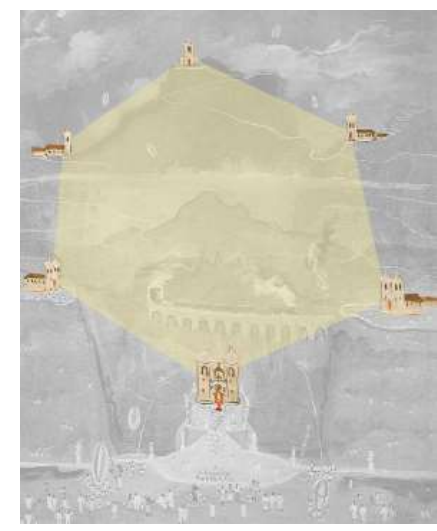


[Figura 35] Leitura de simetria feita pela autora. Exemplos do primeiro, segundo e terceiro caso, respectivamente.
Nessa configuração simétrica, há três casos. O primeiro, no qual o quadro já é simétrico em si mesmo, por conta de ter apenas uma igreja e um elemento dentro da paisagem difusa. O segundo, simétrico com a posição das igrejas, ora com o eixo de simetria marcado na vertical no centro do quadro, ora em uma diagonal facilmente observada. E o terceiro, onde a simetria não se dá apenas com as igrejas, mas sim com a adição de elemento marcante para completar a proporção simétrica.
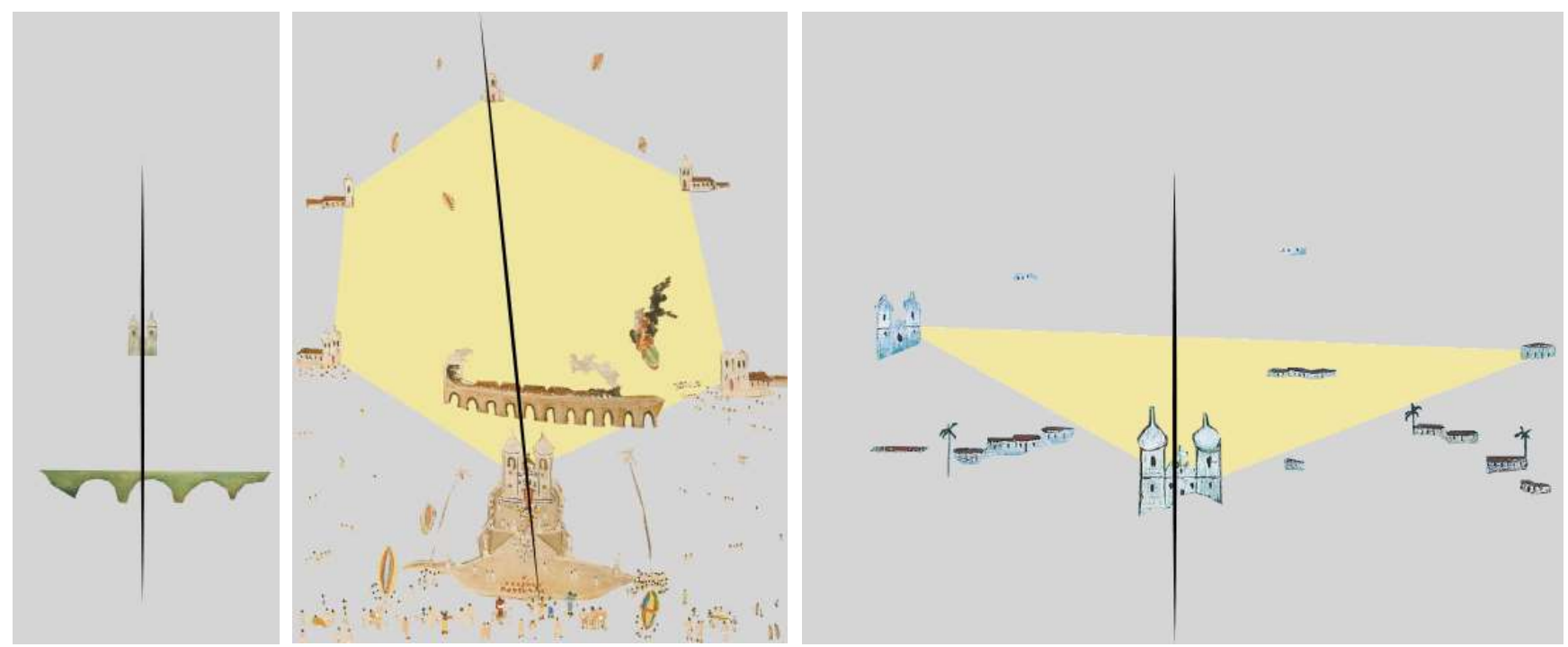

A simetria encontrada permite inferir uma outra chave de leitura em relação àquela relativa aos planos já descritos em textos sobre Guignard. Referese aqui no sentido de romper com a ideia de camadas e se pautar em uma nova conformação, a de espacialidade. Essa noção foi proporcionada pelo próprio percurso de análise das paisagens imaginantes. A leitura começa do todo, de uma estrutura construída pela pintura da paisagem, encontra uma chave de desdobramento, relaciona as partes encontradas, para, ao final, chegar novamente a uma unidade, dessa vez, uma estrutura sintética dos quadros, encontrada pela relação simétrica e espacial dos elementos que configuram as paisagens.

Por outro lado, se esses elementos constituintes da paisagem forem retirados, percebe-se que o fundo se torna homogêneo, no sentido de não ter uma divisão evidente entre o que é terra e o que é ar. Se as obras de Guignard fossem apenas o fundo, dificilmente seriam observadas como paisagens de Ouro Preto, pelo contrário, estariam muito mais próximas de uma pintura abstrata. Mas, ao mesmo tempo, não são puramente abstração, há algo que a aproxima da realidade. Em outras palavras, pode-se dizer que essa pintura de fundo de Guignard está no limite entre a abstração e a figuração. Em algumas obras, o tipo de pincelada se aproxima mais a uma noção de um relevo montanhosa e de um céu nublado e em outra, se afasta do já conhecido (Figura 36). Sendo assim, o que se pode inferir é que se reconhece nas pinturas o que é relevo e o que é céu a partir da presença dos elementos que os caracterizam. As igrejas, as casas, a vegetação e as pessoas afirmam a existência de um solo, enquanto que a ausência desses elementos na parte superior do quadro, ou ainda, a presença de balões, pressupõem o céu.

Sendo assim, o que configura a paisagem de Ouro Preto nas obras dessa segunda fase não é simplesmente a paisagem montanhosa, tampouco, as igrejas. Mas sim a união de ambas, com a espacialidade que as igrejas geram no espaço com uma simetria na configuração de um território 
determinado. Tal espaço simétrico, evidencia a paisagem de Guignard e nos mostra a cidade como um território configurado entre as igrejas. A forma gerada pela ligação desses elementos arquitetônicos realça um entre, um entre que é, ao mesmo tempo, fundo e figura, ora sendo um conjunto de pinceladas soltas que dá suporte para as igrejas pontuados, ora sendo a paisagem natural ouro-pretana que se sobressai frente aos vértices que a emoldura.
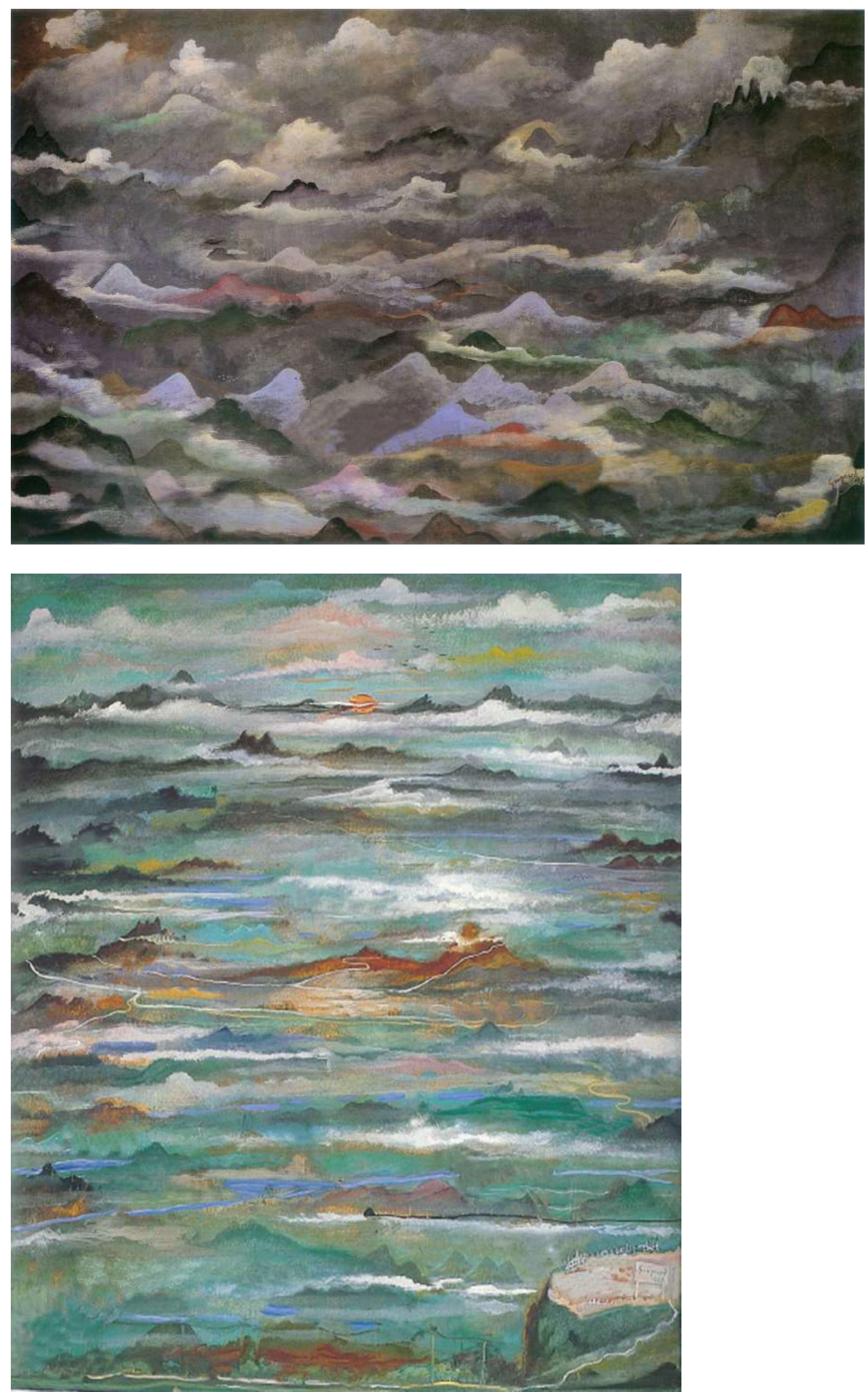

Guignard, ao mostrar a cidade mineira nesse jogo entre figura e fundo, enfatizando tanto os elementos pontuados, quanto a paisagem natural, consegue nos mostrar a sua visão e sua relação com o território ouro-
[Figura 36] Paisagens sem elementos. Paisagem Imaginante, 1950, $80 \times 110 \mathrm{~cm}$ e Paisagem Imaginante, 1955, $95 \times 78 \mathrm{~cm}$.

[Fonte] FROTA, 1997. 


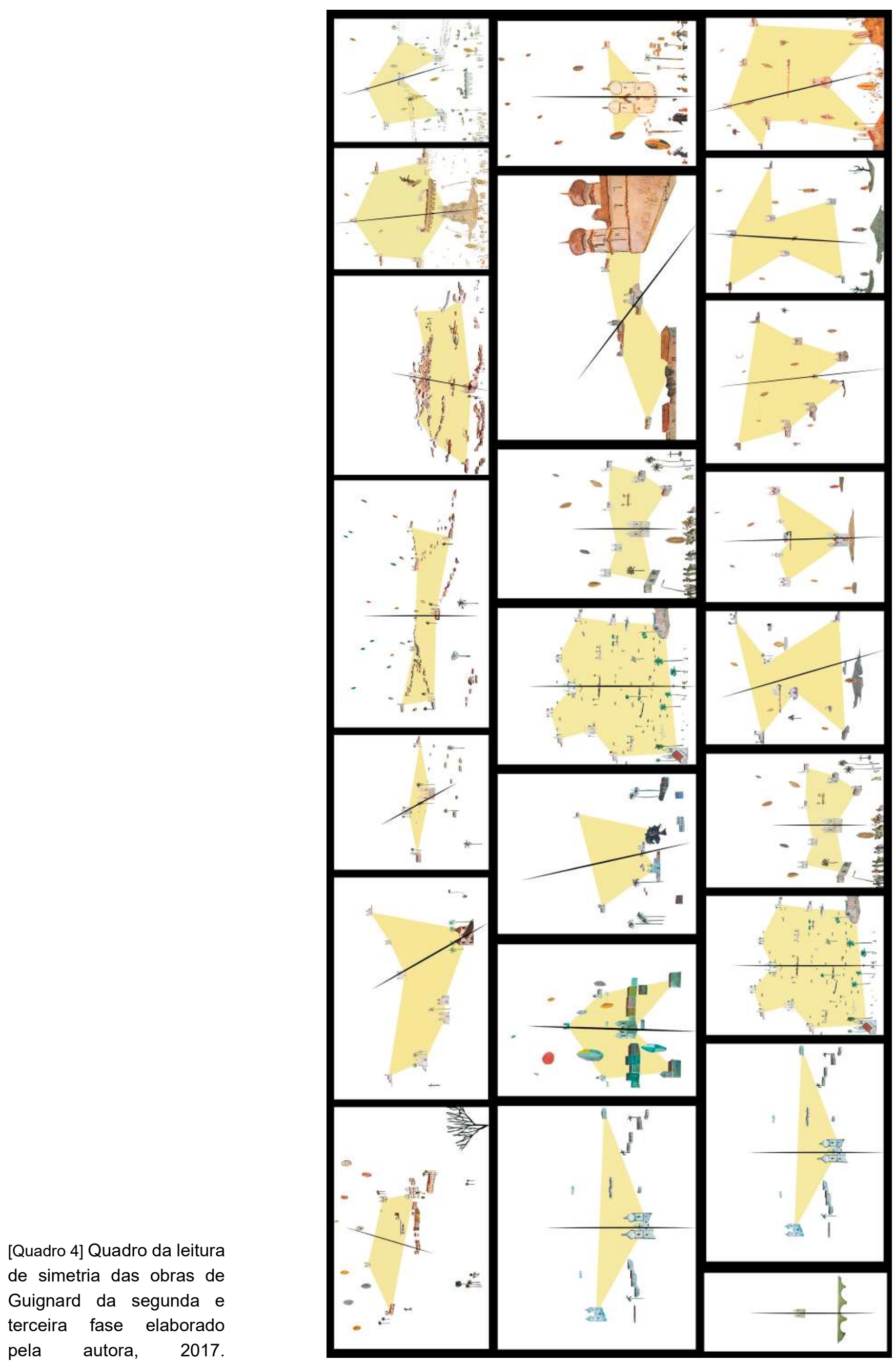


Após falar das pinturas de paisagem, cabe voltar a atenção para os retratos com a paisagem mineira dessa fase. Assim como foi citado na fase anterior, os retratos nessa fase também se assemelham quanto ao modo de pintar das paisagens. O que aparece aqui é uma pincelada mais solta, não preocupada com os pequenos detalhes, mas sim com a experiência diante do observado, assim como a paisagem que se encontra ao fundo. O tipo de pincelada e a paleta de cores escolhida para cada paisagem ao fundo possibilita ver a relação com a pessoa representada. No momento de troca afetiva, a partir da relação entre artista e pessoa observada, Guignard estabelece uma conexão entre os componentes observados e os representa da maneira que os percebe. A sintonia entre figura humana e paisagem é fruto do seu ato perceptivo que, por sua vez, é revelado nos seus quadros.

NaFigura 37, retratode SaraÁvila, porexemplo, tanto a pessoa representada, como a paisagem têm um aspecto mais sério. As cores utilizadas no fundo são mais escuras, assim como no cabelo e na vestimenta. A mulher, a qual aparenta tem um olhar misterioso, relaciona-se com a paisagem pouco definida e obscura, os tons escuros próximos do azul e verde confundem céu e terra, dia e noite. Parece ser difícil compreender essa mulher, assim como a paisagem que a cerca.

A pincelada mais marcada, característica de uma maior liberdade, aparece também na representação de Sara Ávila. Com maior soltura Guignard consegue dar a forma e expressão desejada. Já no retrato de Marília de Dirceu, Figura 38, as pinceladas do pintor não estão nem tão soltas como no retrato anterior, nem tão presas às minúcias como na fase anterior, encontra-se aqui em uma posição intermediária.

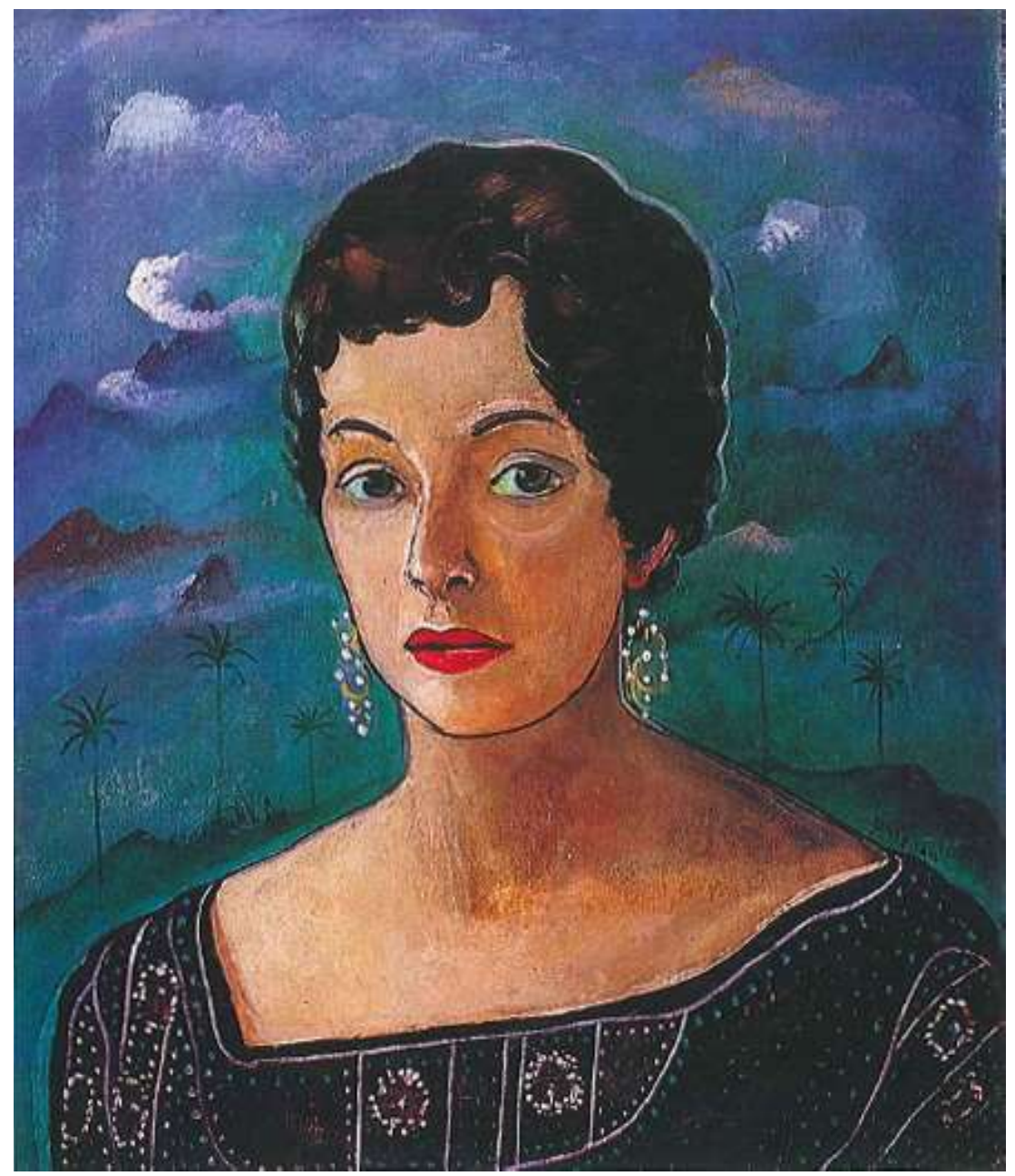

[Figura 37] Retrato de Sara Ávila, 1954, $50 \times 41 \mathrm{~cm}$. [Fonte] FROTA, 1997. 
[Figura 38] Marília de Dirceu, $1957,61,5 \times 51,5 \mathrm{~cm}$. [Fonte] FROTA, 1997.

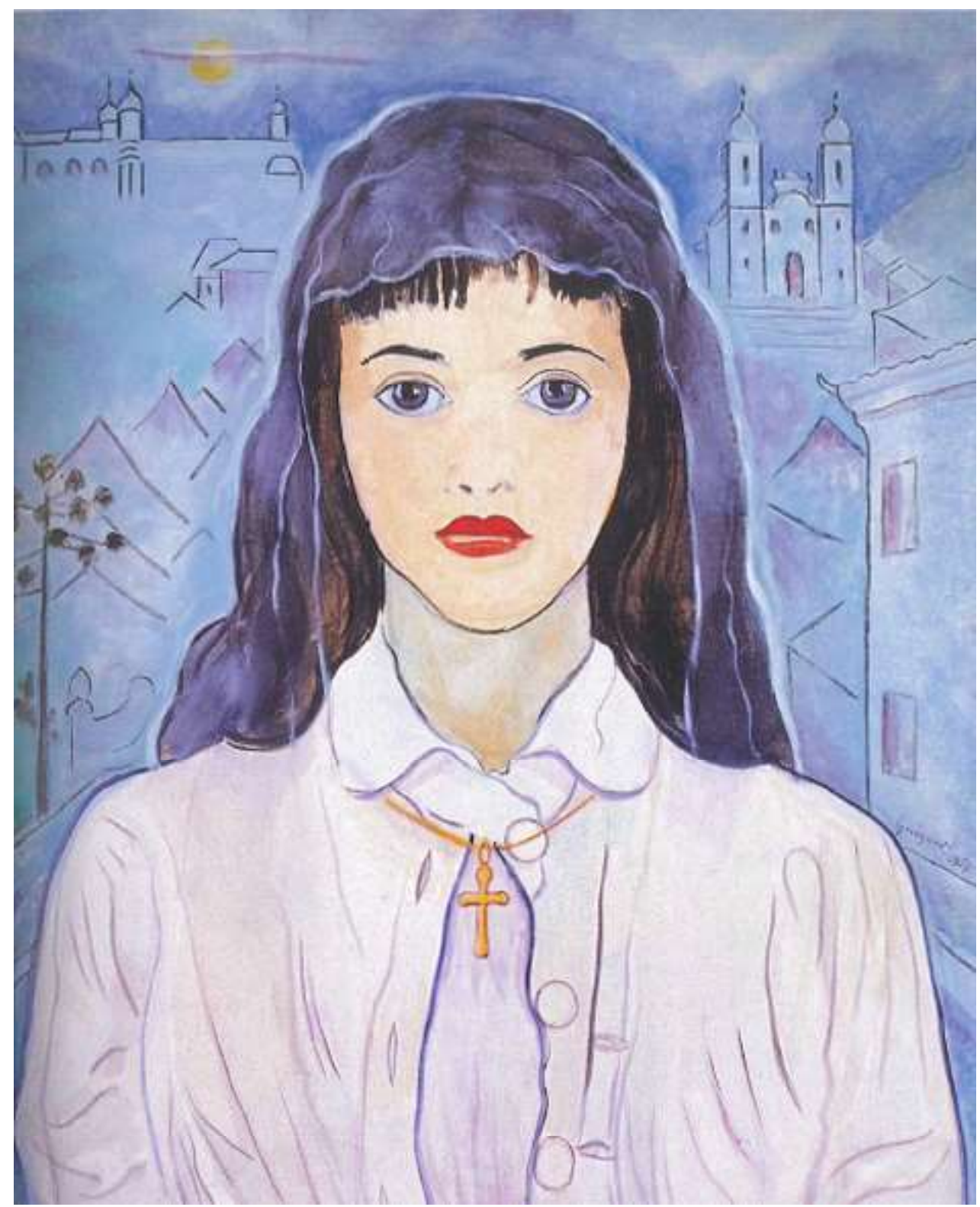

Dentro da segunda fase, ainda se caracterizando como uma obra mais aberta às sensações, Guignard aponta a relação entre plano principal e planos secundários. A opção de Guignard ao se atentar a um contorno mais evidente pode estar relacionada a figura conhecida que foi Marília de Dirceu, numa tentativa de colocá-la em um patamar que beira o ideal, representando-a com um aspecto de pessoa intocável. Isso tanto na representação dela em si - na própria vestimenta, no véu na cabeça, na feição ingênua e nos traços harmoniosos -, quanto na configuração da paisagem ao fundo, além de desenhar as edificações e a vegetação de uma maneira mais suave, mais próxima de uma ingenuidade e infantilidade. Utiliza-se da cor azul clara de um modo geral, para corroborar com tal suavidade.

Outro exemplo é o retrato de Priscila Freire, Figura 39. É possível estabelecer relação entre a figura e o fundo: a expressão mais fechada da representada pressupõe uma paisagem mais séria, mais sombria. $\mathrm{O}$ que contribui para isso são os tons terrosos do quadro, o marrom esverdeado predominante na roupa e no cabelo da Priscila é rebatido para a paisagem ao fundo, cuja a vegetação é extremamente seca, característica de uma paisagem sombria e melancólica. 


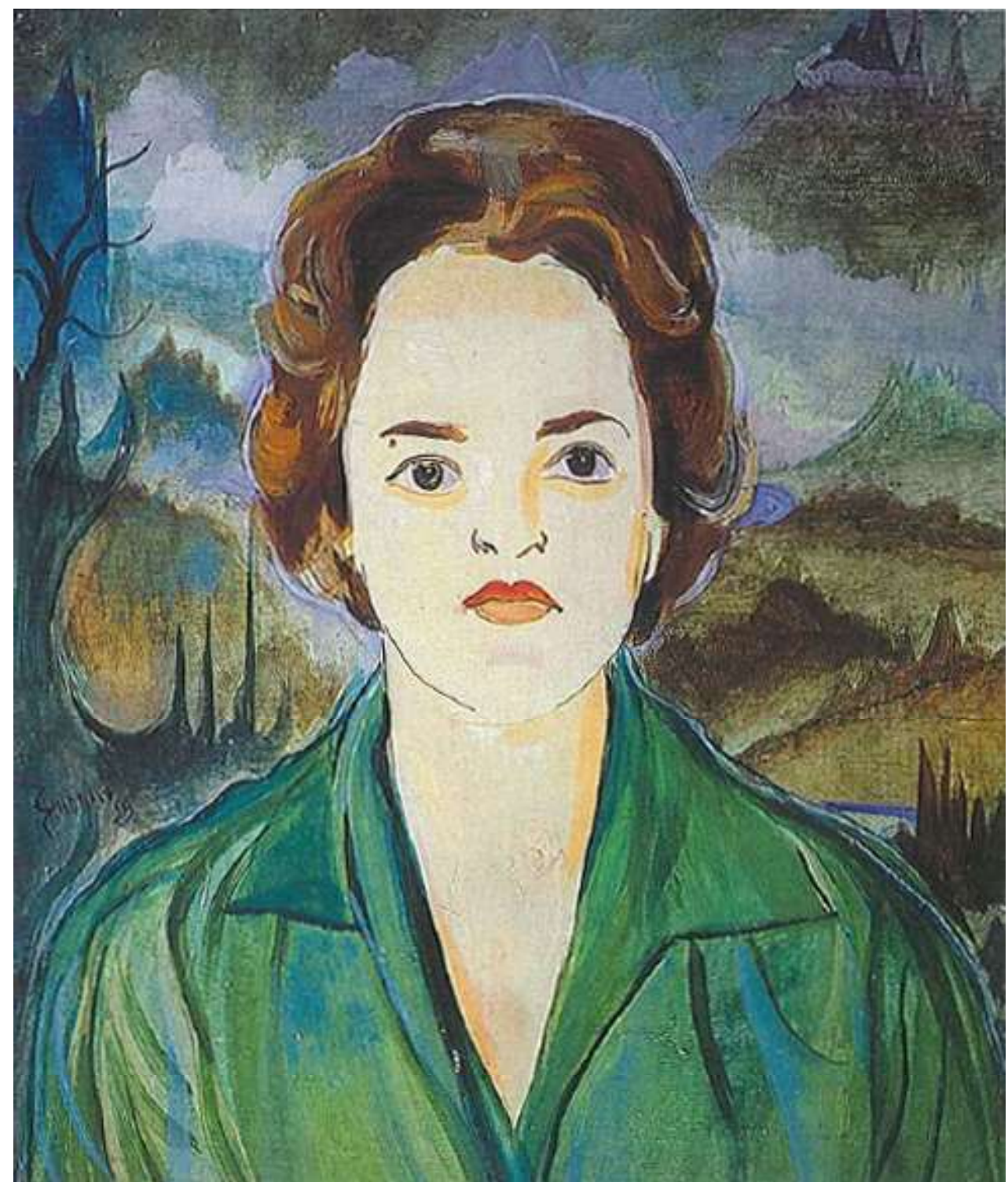

Nesse último caso, como em alguns outros, não há a presença de igrejas no fundo montanhoso, porém o tipo de pincelada e de configuração do relevo são característicos dessa segunda fase, posicionam-se no limite entre a abstração e a figuração. Quando há a presença de igrejas, como na Figura 40, fica ainda mais evidente a aproximação com as paisagens. As igrejas, ou ainda algumas construções arquitetônicas de destaque, configuram-se na espacialidade, pontuadas nas montanhas e em determinadas posições elas acompanham a simetria descrita nessa fase. Nesse caso, o leitor tem uma chave de leitura, o olhar percorre o quadro de modo circular, observando, primeiramente, o retrato e, posteriormente, percorrendo as igrejas ponto a ponto até observar o quadro todo.

Os últimos retratos com a paisagem ouro-pretana ao fundo dessa fase correspondem aos últimos retratos que o artista realizou em vida. Os três retratos de 1961, Figura 41, ainda se enquadram aqui, possuem as mesmas características dos demais retratos já citados e, ao contrário de se aproximarem de uma representação austera, mais imaginativa, são quadros claros, coloridos e, por sua vez, mais alegres. As paisagens ainda se relacionam com o retrato do primeiro plano, isso quanto a condição afetiva entre artista e observado e ao estado de espírito do artista no momento da representação, justamente proporcionado pelo ato perceptivo. AOuro Preto, até então desconhecida no final e início da década de 1940, passa a fazer
[Figura 39] Retrato de Priscila Freire, $1959,55 \times 46 \mathrm{~cm}$. [Fonte] FROTA, 1997.

[Figura 41] Autorretrato, 1961, 64,5 x 50cm; Retrato, 1961, 50 $x 40 \mathrm{~cm}$ e Retrato de Wilson Frade, 1961, 79 x 58,5cm.

[Fonte] FROTA, 1997. Página ao lado. 
(Ouro Preto) vai ocorrendo de modo gradual. A cidade com seus elementos peculiares, tanto arquitetônicos quanto topográficos, afeta o artista de diferentes maneiras ao longo dos anos. A mudança nas representações da paisagem mineira, nessa segunda fase, mostra o processo de construção de uma Ouro Preto particular, a Ouro Preto de Guignard. Um processo de experimentação e de vivência que serão os responsáveis pelos diversos olhares do artista sobre a paisagem ouro-pretana.

[Figura 40] Retrato de Lúcia, $1960,48,2 \times 35,5 \mathrm{~cm}$.

[Fonte] FROTA, 1997.

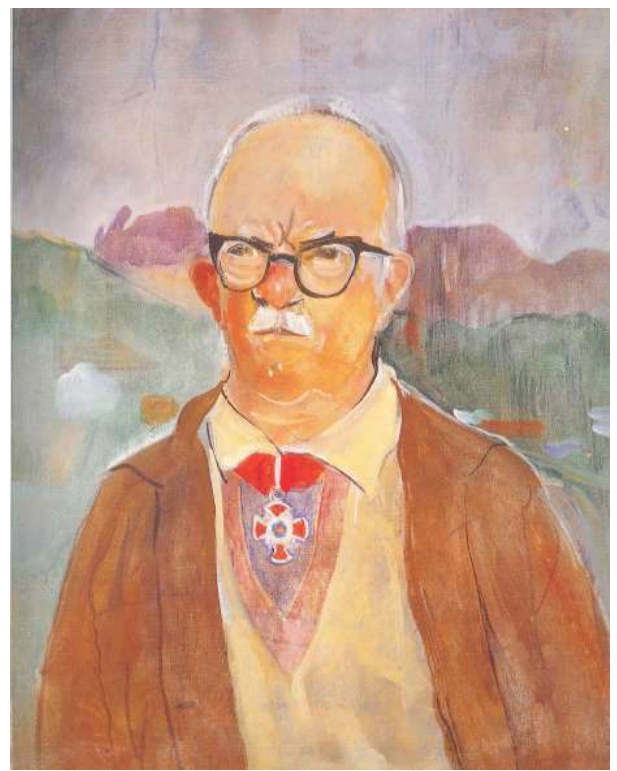

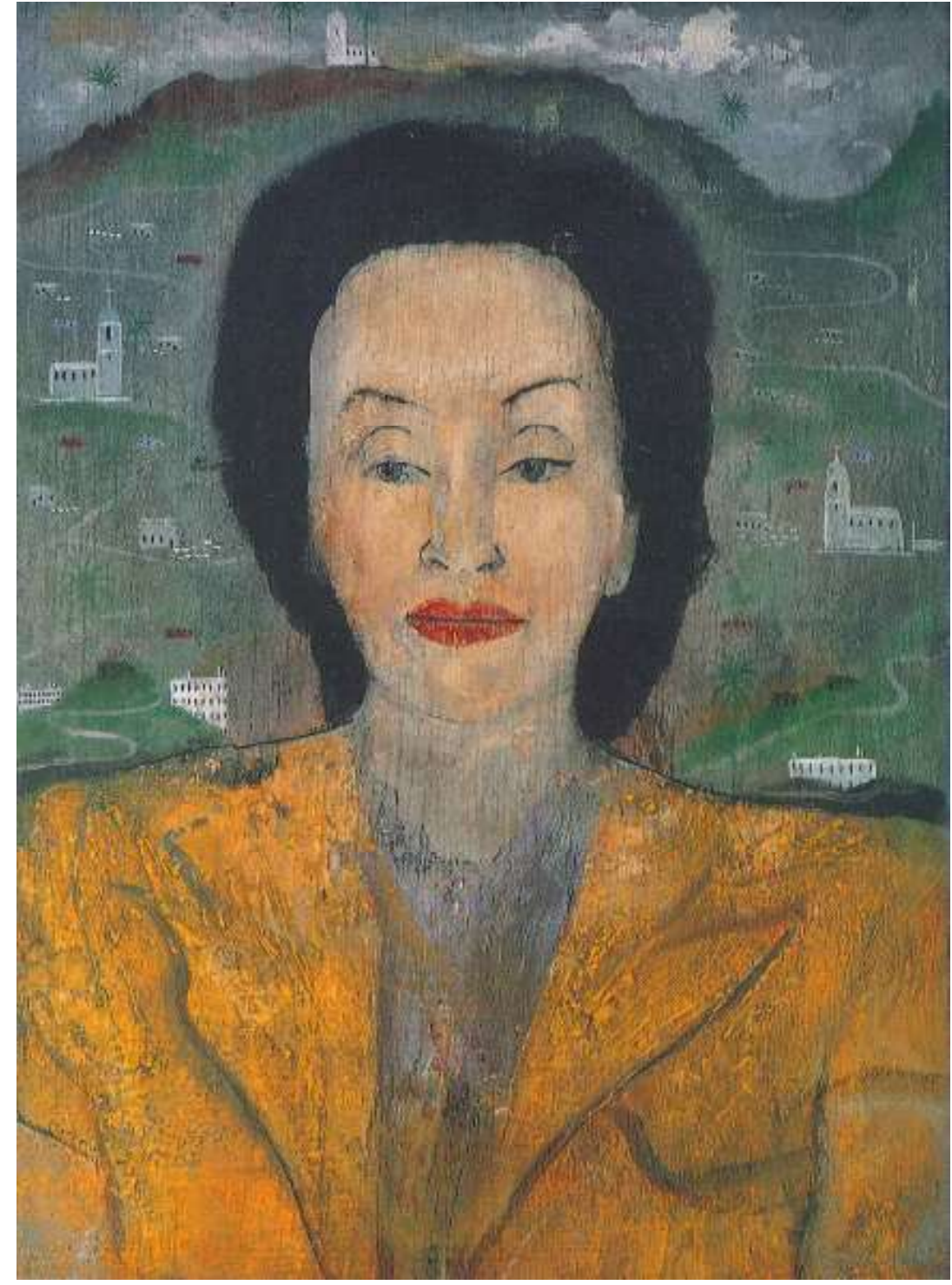
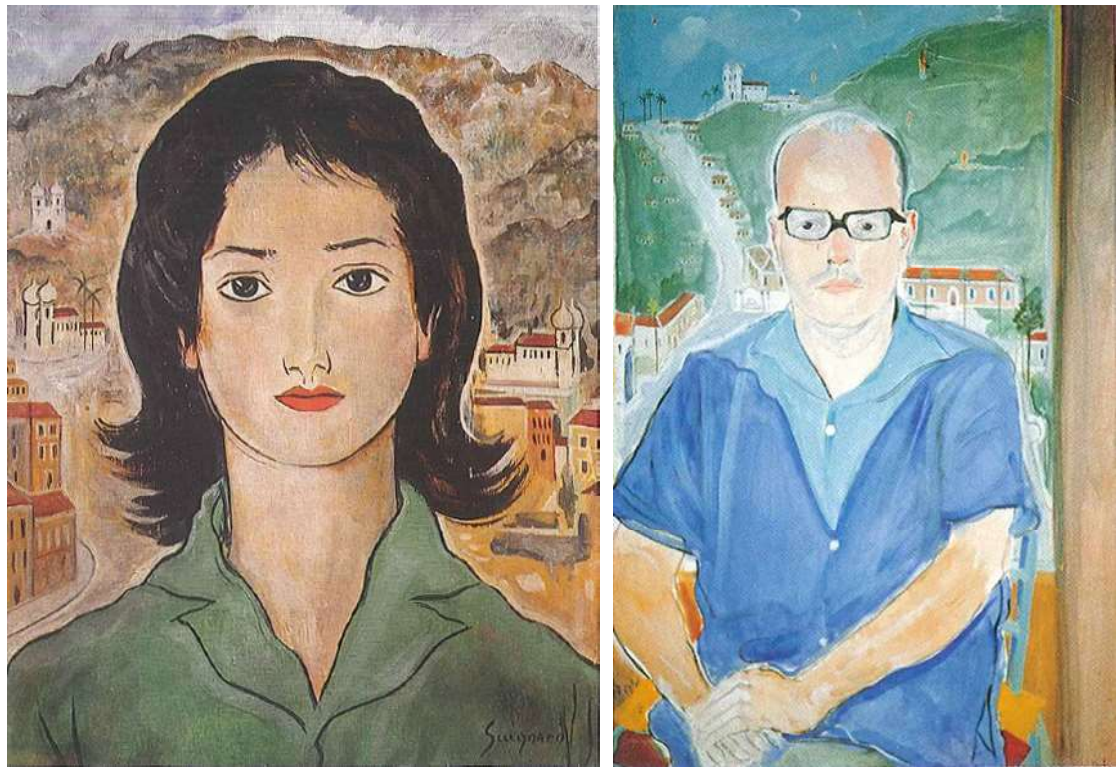


\section{Imaginação}

Por último, a terceira fase corresponde à parte das obras de Guignard do ano de 1961, últimas obras da vida do artista. Mais próximas da configuração do campo plástico da segunda fase, essas últimas obras se diferem mais quanto a percepção do lugar e a aproximação com a realidade. Por mais que ainda seja possível perceber a paisagem de Ouro Preto nessas últimas obras, ela se mostra de maneira bastante distinta o que foi visto até agora.

Quanto aos retratos com paisagem ao fundo, cabe ressaltar de antemão que não há nenhum nessa fase. A paisagem relativa aos sonhos, com caráter melancólico, não aparece nos retratos, o máximo que se tem são paisagens mais nebulosas, mas que ainda fazem parte da segunda fase.

Quanto aos elementos da paisagem, ainda se observa a presença de elementos como balões de São João, pessoas, pontes e, além disso, a relação espacial entre as igrejas como aparecia na segunda fase. Tal relação ainda se assemelha no que se refere a proporção e a simetria entre elas, como foi notada na fase anterior e como aparece nas Figuras 42 e 43.

Já sobre a posição delas no campo plástico, na maioria das vezes, percebese uma ocupação próxima a borda superior do quadro, o que possibilita pensar em duas questões. A primeira que não aparece aqui a separação clara entre céu e terra e as igrejas parecem estar pontuadas tanto no que se pode considerar solo, como se considerar ar, evidente na Figura 44. E a

[Figura 42] Espacialidade das igrejas nas paisagens da segunda fase.

[Figura 43] Espacialidade das igrejas nas paisagens da terceira fase. Paisagem Imaginante, 1961, $61 \mathrm{x}$ $46 \mathrm{~cm}$. [Fonte] FROTA, 1997; Paisagem Imaginante, 1961, $55 \times 46 \mathrm{~cm}$. [Fonte] FROTA, 1997 e Sem título [festa junina], 1961, $50 \times 40 \mathrm{~cm}$. [Fonte] MUSEU LASAR SEGALL, 1992.
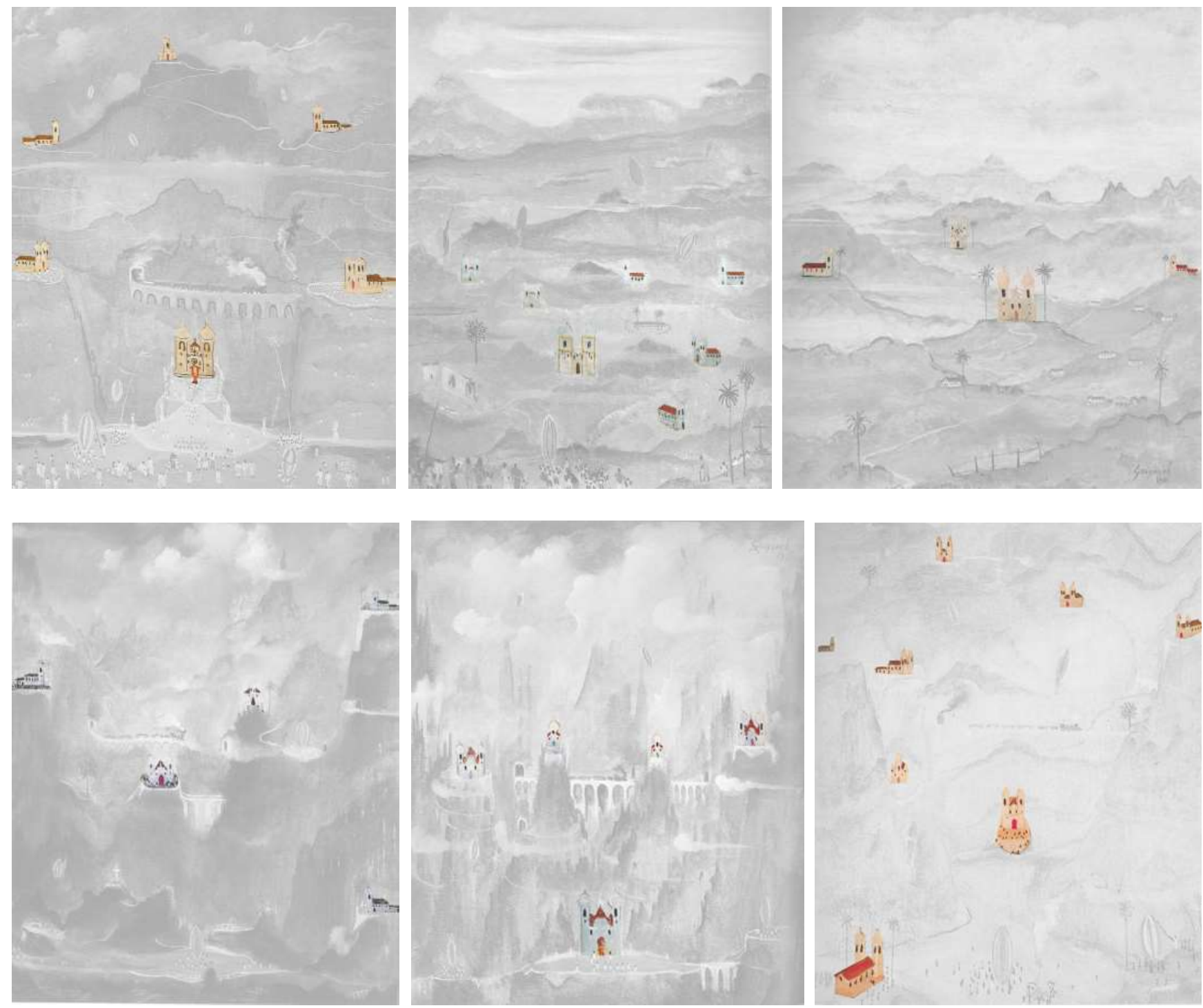
segunda questão é a grande distância entre as igrejas localizadas nos topos das montanhas em relação ao que está fixado no solo, na borda inferior do quadro, em geral, uma aglomeração de pessoas, como na Figura 45.

Essas questões apenas fazem sentido se forem pensadas relativamente ao fundo da paisagem, a maior atenção dessa fase. Enquanto que as igrejas vêm seguindo a linha já citada anteriormente, é no fundo que o artista incorpora novas informações, distanciando a paisagem da realidade e adquirindo proximidade com o mundo imaginário.

Cabe uma ressalva aqui para as pinceladas esbranquiçadas, que inclusive já apareceram antes. É uma característica que contribui bastante para o tom fantasioso e onírico, principalmente dessas últimas paisagens pintadas

[Figura 44] Paisagem Imaginante, 1961, 55 x 46cm. [Fonte] FROTA, 1997.

[Figura 45] Paisagem Imaginante, $1961,61 \times 46 \mathrm{~cm}$. [Fonte] FROTA, 1997.
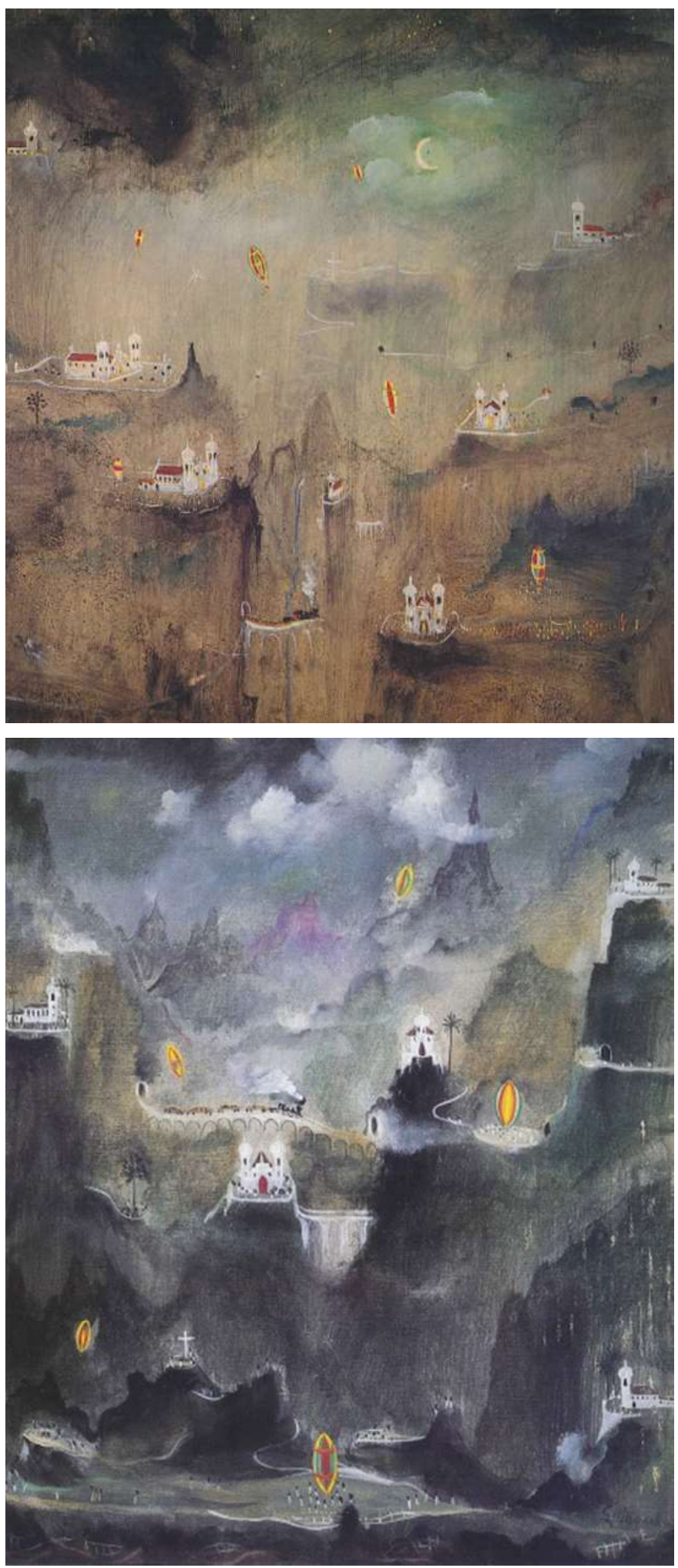
por Guignard. O tom esbranquiçado vai de pinceladas pontuadas, as quais se aproximam dos fenômenos naturais da realidade - nuvens, névoas sobre os vales - mais constantes na segunda fase, para massas e borrões fluidos preenchendo boa parte da paisagem, que é o caso da Figura 45. Juntamente com tons mais escuros, esses borrões criam um fundo mais próximo da abstração, que ora se aproxima de um relevo montanhoso, ora de um céu nublado, ora de um precipício, ora de um deserto, conforme a imaginação. Além disso, essa característica é uma das proximidades da pintura de Guignard com a arte oriental. Na paisagem de Guignard,

Tudo parece flutuar num plano indistinto e fora de foco, o que os chineses chamam de "montanha-d'água", ou seja, quando o horizonte se perde na neblina e o mundo vira um pano de fundo harmônico e etéreo. (MARTí, 2010)

Ainda sobre a relação com a arte oriental, Guignard dispõe os elementos do mesmo modo que os chineses, "com uma diluição de cores que torna quase translúcida a paisagem. São céus leves, como as pinturas no teto das igrejas mineiras". (MARTí, 2010)

Nessas paisagens de 1961, um ano antes de sua morte, Guignard parece evidenciar ao máximo essa abstração. Além disso, a paleta monocromática em tons acinzentados ou então, terrosos, dá um peso melancólico para a paisagem, uma tristeza que pode estar relacionada com os conflitos do fim da vida do artista. A Ouro Preto, tão conhecida e representada por Guignard, parece se mostrar para ele a partir do seu próprio interior, não mais como aquela primeira cidade, de igrejas e casas coloridas, tampouco aquela cidade que tanto percebeu e vivenciou, mas aquela já constituída na sua memória e carregada de sentimentos. As distancias entre as igrejas, aqui, parecem ter se tornado maiores em altura e o caminho a percorrer, mais difícil, íngreme e exaustivo. Características que podem estar relacionadas justamente com a fase pessoal que Guignard estava enfrentando. Por estar doente, ou melhor, debilitado, a cidade que tanto conhecia e percorria passou a ser representada por meio de um caráter hostil, o relevo montanhoso que anteriormente parecia harmonioso passa a ter um caráter sombrio, chegando até a aparentar um penhasco inalcançável. A proximidade das igrejas com o céu e, ao mesmo tempo, os "abismos" representados no lugar do relevo ondulado, mostram a dualidade entre elementos em conflito. Nesse ponto, vale lembrar da colocação de Merleau-Ponty (2004) em A dúvida de Cézanne, ao dizer que o sentido da obra não pode ser determinado pela vida do artista, mas sim que se comunicam e ao conhecermos a sua obra vemos através dela as circunstâncias da vida.

O caráter sombrio da paisagem, além de ser marcado pelos tons escuros de uma paleta monocromática, é corroborado por outras questões. Primeiro, pela falta de vegetação que recobre o relevo mineiro e sem a presença das recorrentes palmeiras dos quadros anteriores. Quando há algum tipo de vegetação são apenas galhos ressecados ou são uma ou outra palmeira quase que sem vida dispersa pela paisagem, como se vê na Figura 46. Segundo pela presença da lua em algumas paisagens. Inserindo a lua, o artista deixa evidente a ideia de noite. A escuridão do fundo se fortalece no aspecto noturno e reforça o aspecto sombrio e melancólico dessa fase, como aparece na Figura 44 e 47.
[Figura 46] Vegetação nas paisagens. Paisagem Imaginante, 1961, $61 \times 46 \mathrm{~cm}$. [Fonte] FROTA, 1997; Sem título [festa junina], 1961, $50 \mathrm{x}$ $40 \mathrm{~cm}$. [Fonte] MUSEU LASAR SEGALL, 1992 e Paisagem Imaginante, 1961, $55 \times 46 \mathrm{~cm}$. [Fonte] FROTA, 1997. Página ao lado. 
- pessoas e balões - dão movimento e, consequentemente, vida a estas últimas paisagens. Há um tenso equilíbrio entre o que parece estático e fantasmagórico e o que anima a paisagem e se relaciona com a realidade. Os balões aparecem desde o momento em que estão saindo das mãos das pessoas até estarem no ponto mais alto do quadro, vistos tanto na Figura 45 e na Figura 47. Nesse sentido, ao observar os balões tem-se a sensação de estarem em constante movimento, tornando a sombria paisagem,
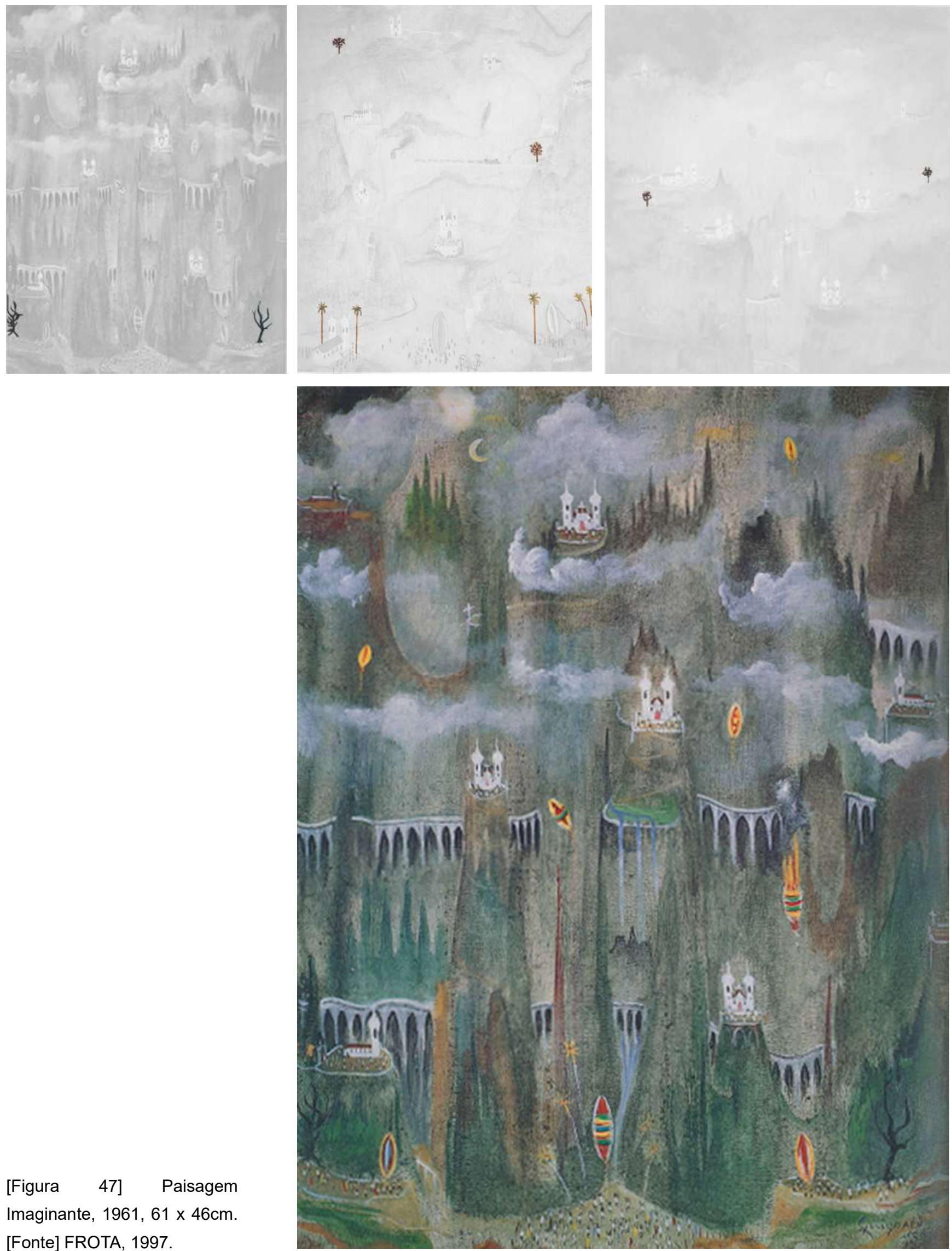
dinâmica. É sabido que a adoração pela festa de São João por Guignard era uma lembrança muito forte de sua infância que se relacionava com o aniversário do seu pai. Nessas últimas paisagens, relativas à memória e à imaginação do artista, não poderia ter característica mais recorrente que a festa junina. Mesmo com aspecto pesado e melancólico, possivelmente referente às dificuldades do fim de sua vida, como já dito, Guignard ainda consegue mostrar a sua alegria ao resgatar a memória das festas de São João.

Ainda quanto aos balões, chama a atenção a escolha do artista pelo uso de cores primárias, a cor predominante é a amarela, mas também há a combinação das três cores em um único balão. A combinação entre amarelo e vermelho quando inserida na paisagem toda e vista a uma certa distância aparenta ser balões com coloração alaranjada, enquanto que se a combinação se dá entre o amarelo e o azul, vê-se balões esverdeados. Com a utilização das três cores primárias, Guignard consegue representar
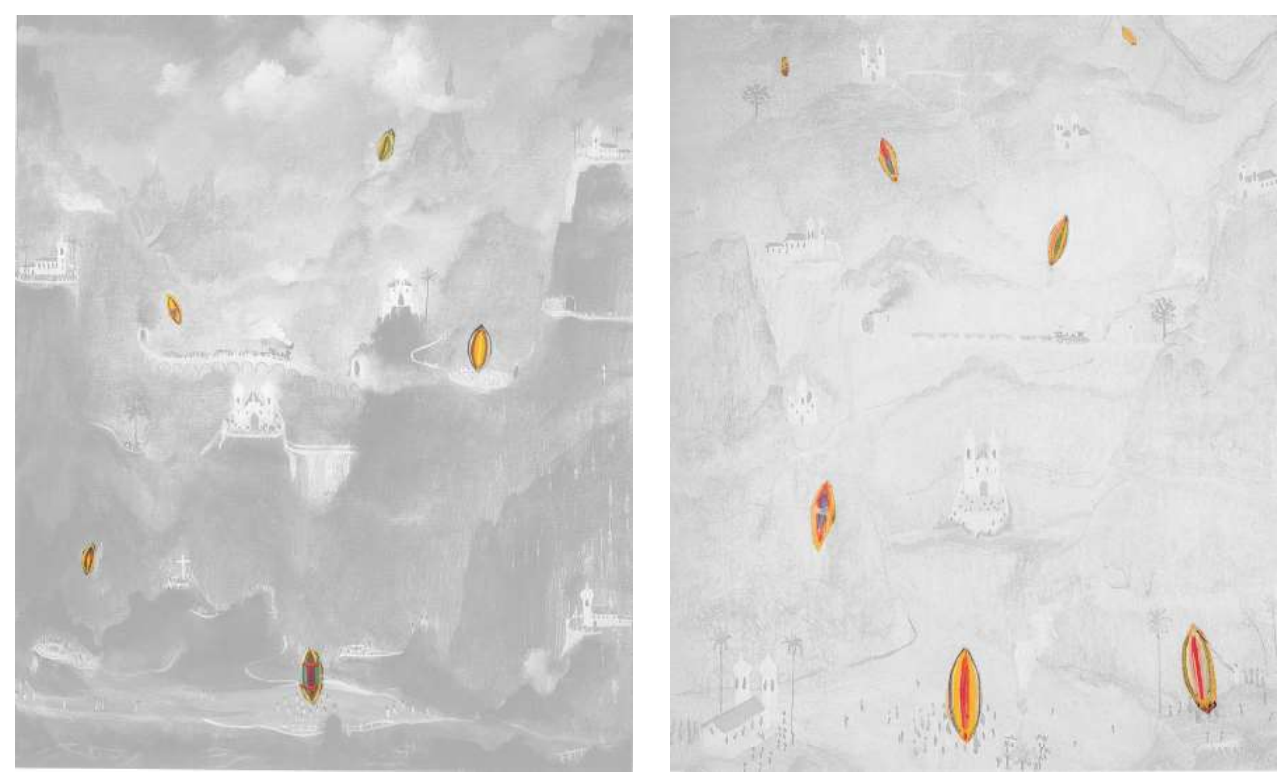

variados balões e, ainda, transpassar diferentes sensações na sua paisagem ao confrontar cores mais quentes com uma paleta escura e monocromática.

Com a grande proximidade entre essa fase e a anterior, no que diz respeito à espacialidade das igrejas, foi possível observar também a simetria do quadro ao criar uma forma com a união das igrejas. No entanto, a simetria encontrada é apenas a do último caso, isto é, ela não se dá apenas com as igrejas, mas sim com a adição de um elemento marcante que completar a proporção simétrica. Essa simetria equilibra o quadro e mostra ao leitor um caminho a ser seguido ao observá-lo. Ao olhar um lado, pode buscar uma correspondência no outro.

A relação simétrica da fase anterior tem continuidade nessa última fase, no entanto o que se modifica aqui é o entre gerado pela ligação dos elementos pontuados. O fundo representativo da paisagem natural de Ouro Preto construído anteriormente por Guignard, numa aproximação entre observação e observado (experiência), é desmontado nessa fase. O entre que caracterizava o céu e o relevo ondulado de uma maneira mais amena (Figura 50) se desmonta para um entre austero e configurado de maneira mais brusca, com relações mais verticais que onduladas (Figura 51).

O jogo de figura (frente) e fundo, nesse caso, dá enfoque para uma nova
[Figura 49] Leitura de simetria feita pela autora. Paisagem Imaginante, 1961, $55 \mathrm{x}$ $46 \mathrm{~cm}$; Paisagem Imaginante, $1961,61 \times 46 \mathrm{~cm}$ e Paisagem Imaginante, 1961, 55 x 46cm. [Fonte] FROTA, 1997. Página ao lado.
[Figura 48] Balões nas paisagens. Paisagem Imaginante, 1961, 61 x 46cm. [Fonte] FROTA, 1997 e Sem título [festa junina], 1961, $50 \mathrm{x}$ $40 \mathrm{~cm}$. [Fonte] MUSEU LASAR SEGALL, 1992. 


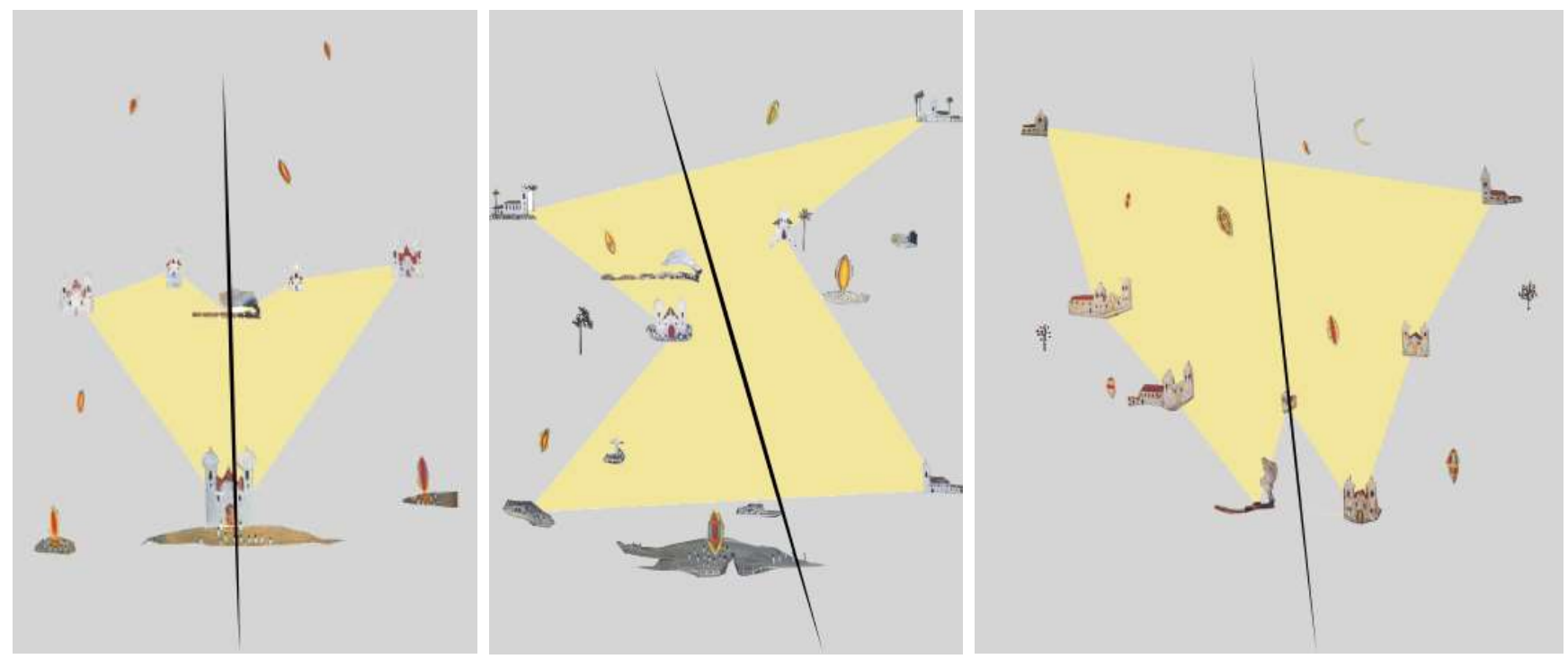

caminhar para um outro mundo, para o mundo interior de Guignard. Não tão reconhecível, essa outra Ouro Preto ainda carrega a espacialidade das igrejas - aquilo que é próximo da experiência do artista frente ao observado -, mas nos mostra a sua outra faceta, esse entre que nos faz ter acesso ao seu interior. As extremidades da forma gerada podem ser pensadas

[Figura 50] Paisagens sem elementos - segunda fase. Paisagem Imaginária, 1952, $160 \times 70,5 \mathrm{~cm}$. [Fonte] FROTA, 1997 e Paisagem de Minas, década de 1940, 32 × 40cm. [Fonte] Alberto da Veiga Guignard, 1896-1962, 2005.
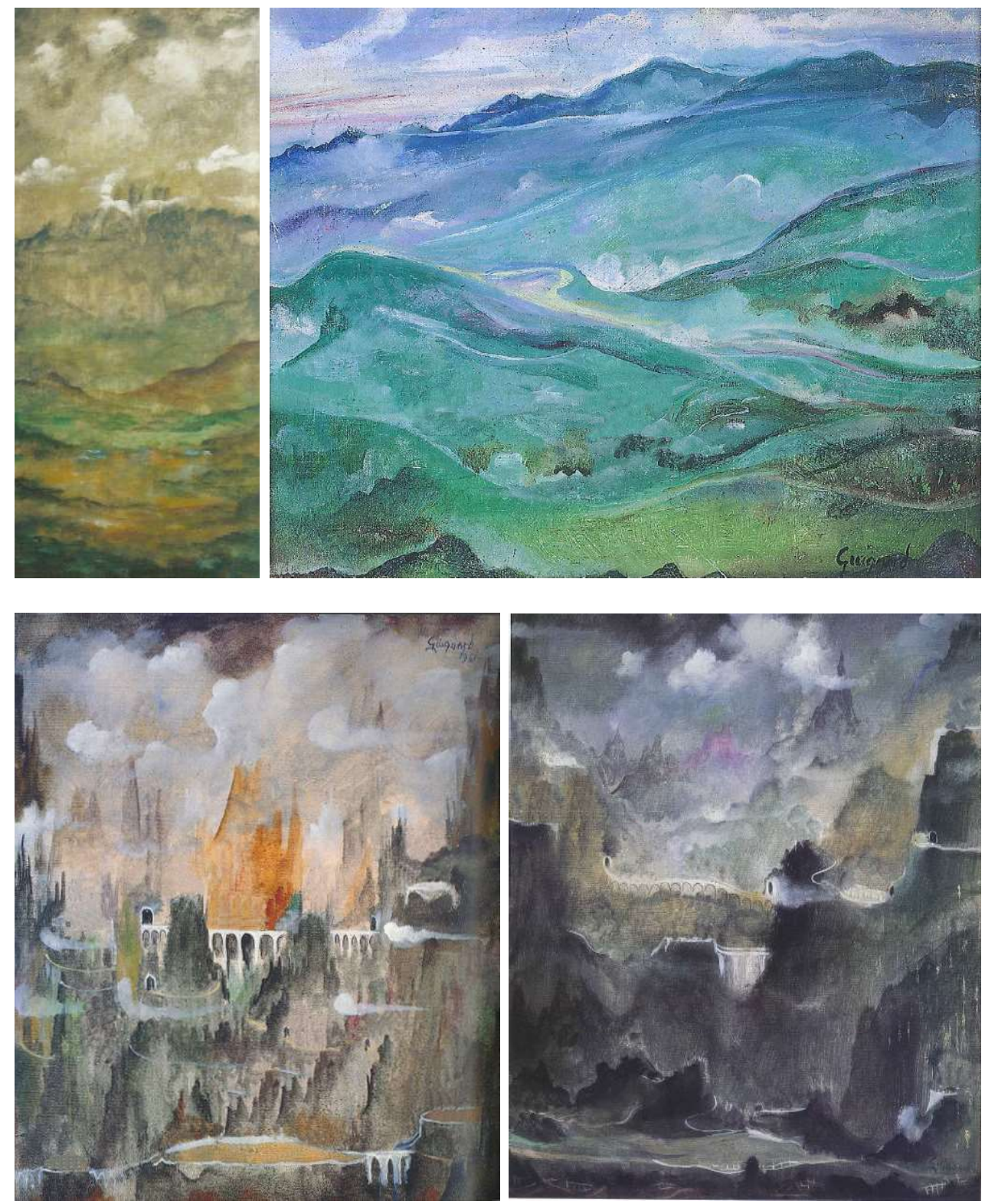

[Figura 51] Paisagens sem elementos - terceira fase. Paisagem Imaginante, 1961, 55 x 46cm; Paisagem Imaginante, 1961, $61 \times 46 \mathrm{~cm}$. [Fonte] FROTA, 1997. 
como uma janela, uma janela que emoldura um território, que possibilita ver uma paisagem ouro-pretana e, mais do que isso, possibilita ver a alma (sentido de interior) do artista. Essa possibilidade de contato com o interior do artista se configura no que Merleau-Ponty chama de consciência de si.

Dizer que Guignard nos revela o seu interior por meio de sua pintura é dizer que Guignard toma contato com a consciência de si, lembrando que essa consciência se fundamenta na experiência perceptiva com o mundo, como discutido no primeiro capítulo. Isso porque ao vivenciar a cidade de Ouro Preto por um longo período, a condição afetiva vai se alterando, bem como a sua percepção, já que a percepção nunca é fechada, ela se altera conforme a comunicação do sujeito com o mundo em determinado contexto e conforme o reconhecimento do próprio sujeito nesse processo de experimentação. No contato de maior experimentação, de maior intimidade com o lugar, Guignard se reconhece.

Todo pensamento de algo é ao mesmo tempo consciência de si, na falta do que ele não poderia ter objeto. Na raiz de todas as nossas experiências e de todas as nossas reflexões encontramos então um ser que se reconhece a si mesmo imediatamente, porque ele é seu saber de si e de todas as coisas, e que conhece sua própria existência não por constatação e como um fato dado, ou por uma inferência a partir de uma ideia de si mesmo, mas por contato direto com essa ideia. A consciência de si é o próprio ser do espírito em exercício. (MERLEAU-PONTY, 1999, p. 496/497)

Guignard segue um caminho que vai de uma representação mais próxima da realidade e mais concreta para uma cada vez mais afetiva, passando, num ponto intermediário, para uma representação mais próxima da experiência do lugar e tocando, ao final, o mundo da imaginação, dos sonhos, da fantasia. Esse processo de anos de relação com a cidade, de relação consigo mesmo, de maturidade com a pintura é evidenciado nas suas paisagens. Como diz Lélia Coelho Frota (2005, p. 37), desmaterializante e ascético, caminha Guignard ano a ano.

A percepção de um indivíduo pode alterar-se à medida que adquire novo conhecimento ou informação, por exemplo, de um determinado espaço. Isto significa que a sua vivência e experiência estão em constante avanço na percepção desse espaço. (FIGUEIREDO, 2015, p. 88)

Segundo Merleau-Ponty (FP), a experiência se constroi a partir do mundo vivido - esse no qual estamos inserido - e ela está relacionada com a própria qualidade do objeto, entendendo qualidade como uma propriedade do objeto, a qual demanda um tempo para ser assimilada e demanda também atenção, ou seja, uma nova maneira de se relacionar com o objeto, de apreender suas características. Esse processo de se relacionar com o objeto, no caso, com o lugar Ouro Preto, depois de algum tempo e de diferentes percepções sobre o lugar e de trocas afetivas possibilitadas durante a construção de diversas representações pictóricas, tornou o vínculo de Guignard com o mundo a sua volta mais estreito e seu repertório, que advém de suas experiências, torna-se mais amplo. Posteriormente, vê-se uma outra relação do artista com o lugar, uma relação que se distancia da 
realidade e se aproxima do campo das memórias. Segundo Merleau-Ponty, primeiro é preciso que a experiência tome sentido para depois a lembrança de algo surgir. Após conhecer Ouro Preto, apreender as características que se mostraram a ele, Guignard pode-se abrir às lembranças, àquilo que retomava a ideia daquele lugar afetado e afetando aquilo que advinha do seu interior, da sua imaginação.

Em algumas fontes teóricas, as paisagens de Guignard são citadas como "Imaginárias". Pensando no significado de imaginária, tem-se aquilo que só existe na imaginação e, nesse caso, uma paisagem que existe na imaginação do sujeito que a produz, Guignard. No entanto, o mais recorrente nas teorias é a denominação "Paisagem Imaginante", o que nos leva a outro viés. Nas palavras de Lélia Frota presentes no catálogo de exposição Alberto da Veiga Guignard, 1896-1962 (2005, p. 37-38),

Imaginantes porque são a síntese, a fusão em permanente devir da sua vivência das cidades históricas de Minas, onde montanhas, igrejas, grupo de pessoas em festas são transformados por ele em signos que pontuam a representação do seu olhar metafísico sobre o mundo.

O significado estrito da palavra imaginante é definido como aquele que imagina. Ao predicar as paisagens de imaginantes, o sujeito, nesse caso, passa a ser as próprias paisagens, elas possuem o direito de imaginar. Essa colocação na abordagem merleau-pontyniana pode ser pensada na noção de afetividade, as coisas no mundo não são estáticas e, muito menos, apenas alteradas pelo sujeito desse mundo, há uma reciprocidade entre coisa e sujeito, uma condição afetiva que faz com que exista uma relação mútua entre quem afeta e quem é afetado. Assim, ao predicar as paisagens de imaginantes, é evidenciada a ideia de que a paisagem, como coisa, passa a afetar o sujeito, Guignard.

Nesse sentido, ao invés de colocarmos Guignard apenas como o sujeito, é possível considerar a paisagem como sujeito, numa relação entre Guignard-sujeito e paisagem-coisa e entre Guignard-coisa e paisagemsujeito. De maneira resumida, podemos pensar no percurso da produção das paisagens como: Guignard percebe a paisagem, a paisagem se mostra para ele e ele se reconhece na paisagem.

Na primeira fase (Representação), tinha-se uma relação à distância. A representação se constituía mais próxima do repertório já conhecido do artista: o modo acadêmico. Um representar mais descritivo e com base na troca entre sujeito e objeto ainda superficial, um contato ainda tímido.

Já na segunda fase (Experiência), a relação entre sujeito e objeto fica mais próxima e possibilita o processo de experienciar o lugar. Uma proximidade que proporciona uma liberdade pictórica. Guignard afeta a paisagem e é afetado por ela. Nesse processo de experimentação, Guignard toma consciência do lugar, no sentido de que se comunica interiormente com esse lugar pelo seu corpo, meio pelo qual acontece a percepção e a afetividade.

Esse tomar consciência vai se tornando mais evidente nas pinturas do artista, especialmente nas obras da terceira fase (Imaginação). Para além da consciência do lugar, Guignard toma consciência de si. A paisagem de Ouro Preto aparece não tão reconhecível para quem a observa, mas sim reconhecível para Guignard. A paisagem parece estar tão interiorizada para 
ele que a condição afetiva proporciona um abrir para si. A experiência da paisagem passa a ser também a experiência e o reconhecimento de si, o que se pode dizer que no maior grau do processo de afetividade, Guignard chega a consciência de si. 


\section{considerações finais}


A pesquisa desenvolvida aqui buscou responder a hipótese de ser possível perceber a experiência do artista Guignard em Ouro Preto por meio de suas representações pictóricas. Para isso, utilizou-se da abordagem merleaupontyniana, a qual há indissociabilidade entre autor/representação e sujeito/mundo, localizados em um contexto histórico-social e a qual coloca a pintura como o meio mais eficaz de contato com o mundo da percepção.

O desenvolvimento da pesquisa se constituiu em duas partes (I e II). A primeira se pautou em contextualizar a abordagem de Merleau-Ponty, a noção de paisagem desde sua definição inicial até a atualização do conceito com seus desdobramentos na estética do pitoresco e nas práticas de viagem dos artistas-viajantes e, também, contextualizar a cidade de Ouro Preto. Já a segunda se firmou no aprofundamento do objeto da pesquisa, propriamente: o artista Guignard.

Na parte I, o primeiro capítulo, espaço de discussão da metodologia, foi estruturado conforme as principais concepções de Merleau-Ponty e a sequência delas vieram para facilitar o entendimento sobre o que se propôs refletir, deixando claro que esta foi uma lógica criada pela autora, segundo interesse da pesquisa.

No segundo capítulo, ao apresentar a noção de paisagem, o seu percurso e seu desdobramento no modelo de apreciação do pitoresco, chega-se ao contraexemplo, buscando compreender o primeiro contexto em que as representações pictóricas do território e da cultura brasileira ganharam destaque, justamente por evidenciar o tipicamente brasileiro: o contexto dos artistas-viajantes. A prática dos artistas-viajantes foi mostrada desde o século $\mathrm{XVI}$, dando enfoque para essa prática no século $\mathrm{XIX}$, quando se intensificou. Foi escolhido um artista representante dessa época, Rugendas, o qual veio a corroborar como um contraexemplo para as discussões colocadas por Merleau-Ponty acerca da pintura e, como consequência, como um contraexemplo do objeto empírico proposto para essa pesquisa. $\mathrm{O}$ artista representou Ouro Preto, porém não teve um contato direto com a cidade, esteve de passagem e não conseguiu adquirir uma experiência, uma vivência, uma relação que fosse para além da superficialidade.

O terceiro capítulo, destinado a Ouro Preto, iniciou-se com a formação da cidade mineira como uma construção cultural e histórica. Para isso, contou-se com o processo de formação da cidade e sua evolução até a atualidade, cuja topografia acidentada foi determinante para a forma de ocupação e para seu caráter peculiar. Ao abordar o processo de construção e expansão de Ouro Preto, foi possível relacioná-lo com o período em que Guignard viveu nessa cidade e como ela aparece em suas obras.

Na parte II, o primeiro capítulo, baseado no objeto principal da pesquisa, foi sistematizado de modo a situar o contexto do século $X X$ - contexto em que as representações pictóricas evidenciaram a raiz brasileira -, por meio do conhecimento do artista Guignard, desde sua biografia, com destaque ao seu percurso como professor até a fase em que viveu em Ouro Preto. Guignard se sobressai quanto a pesquisa plástica empenhada pelo modernismo, para além da liberdade, nele é possível ver o caráter particular do Brasil.

A relação intensa que, através de um projeto poético, sua pintura estabelece com o modelo, a encaminha para uma apreensão aguda do homem e da paisagem brasileiros. Este é o fundamento da chamada "brasilidade" da obra de Guignard, que nada tem a ver com 
No segundo e último capítulo, reservado às representações pictóricas, aplicou-se as noções colocadas por Merleau-Ponty no processo de análise das pinturas de paisagem ouro-pretana produzidas por Guignard. Nesse processo ainda foram retomadas algumas reflexões colocadas pelo filósofo na Fenomenologia da Percepção (1945).

A análise das pinturas de paisagem nos fez identificar um percurso seguido por Guignard, o qual foi dividido em três fases. De uma fase para outra foi possível perceber uma evolução quanto a liberdade expressiva e, mais do que isso, questões distintas que surgiam e questões que se mantinham, numa noção de continuidade e ruptura dentro da sua própria obra.

Da primeira fase (Representação) para a segunda (Experiência), a distinção se dá quanto ao desaparecimento do primeiro plano e a continuidade, pela mesma maneira de representar os demais planos - igrejas dispersas pontuando o relevo ondulado e demais elementos conformando a paisagem, como pequenas casas, balões e vegetação -, os quais passaram a constituir a paisagem da segunda fase como um todo (Figura 52).

Já a relação entre a segunda e terceira fase se consolida na ideia de manter a espacialidade das igrejas e a simetria e desconstruir o fundo sobre o qual elas estão inseridas (Figura 53).

O que se percebe de relação entre as três fases são as igrejas pontuadas na paisagem, que, progressivamente, vão se evidenciando quanto a espacialidade gerada no campo pictórico e quanto a uma simetria que as uni e que enquadra a paisagem localizada entre, num processo gradativo de desmaterialização da obra do pintor.

A visão de Guignard foi de uma pessoa que vivenciou bastante a cidade e que conseguiu captar não só pontos de vistas próximos, como também

[Figura 52] Passagem da primeira para segunda fase.

[Figura 53] Passagem da segunda para terceira fase.
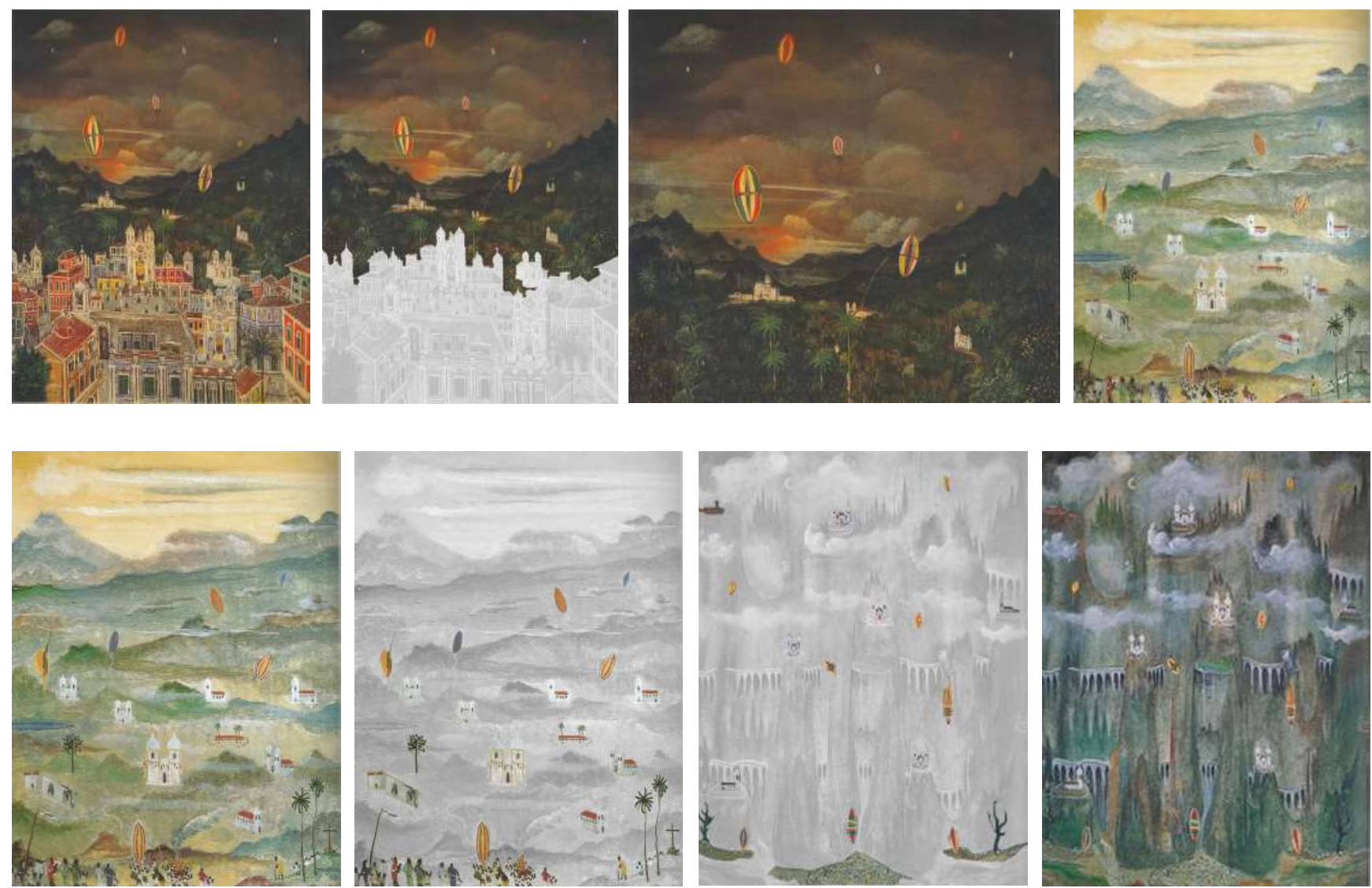
distantes, ora com uma representação mais descritiva e detalhada, ora mais solta e próxima da experiência do lugar e ora mais afetiva e relativa à memória, no entanto, sempre deixando reconhecer a cidade de Ouro Preto. Inclusive quando parece ser representações meramente fantasiosas, ainda se tem muito da cidade mineira, da configuração das construções religiosas nas montanhas, do aspecto difuso marcado pelas névoas, como se pode ver nessas fotografias de Ouro Preto da época de Guignard (Figura 54 e 55,56 e 57).

Toda a análise elaborada até aqui possibilitou um caminho para entender como se deu a experiência do artista em Ouro Preto e mais, como era a sua Ouro Preto, vista em diferentes momentos. Isto é, a partir da sua visão da cidade, da relação dos seus componentes e daquilo que mais o chamava a atenção é que compõe a sua paisagem, dispondo de determinadas igrejas, de determinados ângulos e distanciamentos, de determinada cena urbana. Guignard se utiliza da espacialidade das igrejas configuradas com base em uma simetria, a qual evidencia um entre, um território definido. Diante disso, pode-se pensar que, para Guignard, estar em Ouro Preto é estar entre as igrejas?

Além disso, fala-se em Ouro Preto de Guignard, por ser a visão do artista

[Figura 54] Paisagem de Ouro Preto, período entre 1923 a 1950.

[Fonte] Acervo fotográfico Luiz Fontana, Instituto de Filosofia, Artes e Cultura (IFAC).

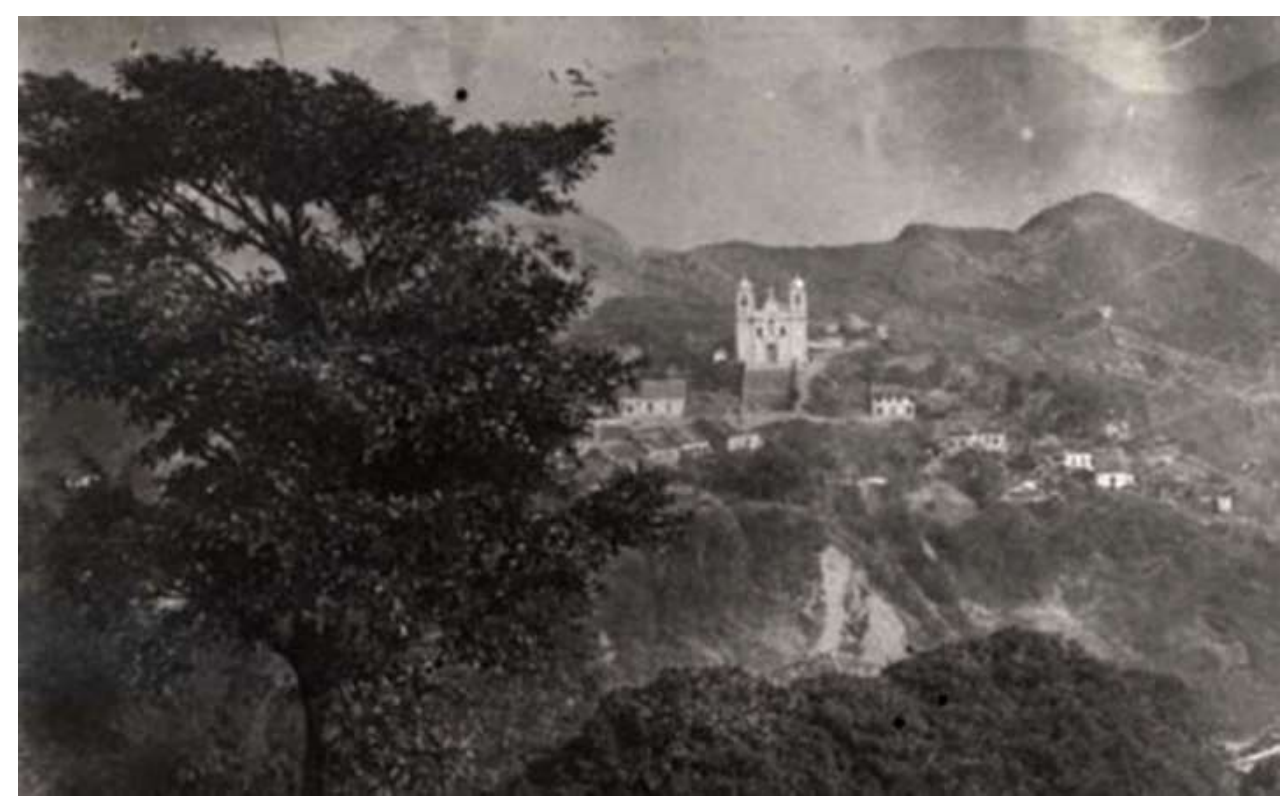

[Figura 55] Paisagem de Ouro Preto, período entre 1923 a 1950.

[Fonte] Acervo fotográfico Luiz Fontana, Instituto de Filosofia, Artes e Cultura (IFAC).

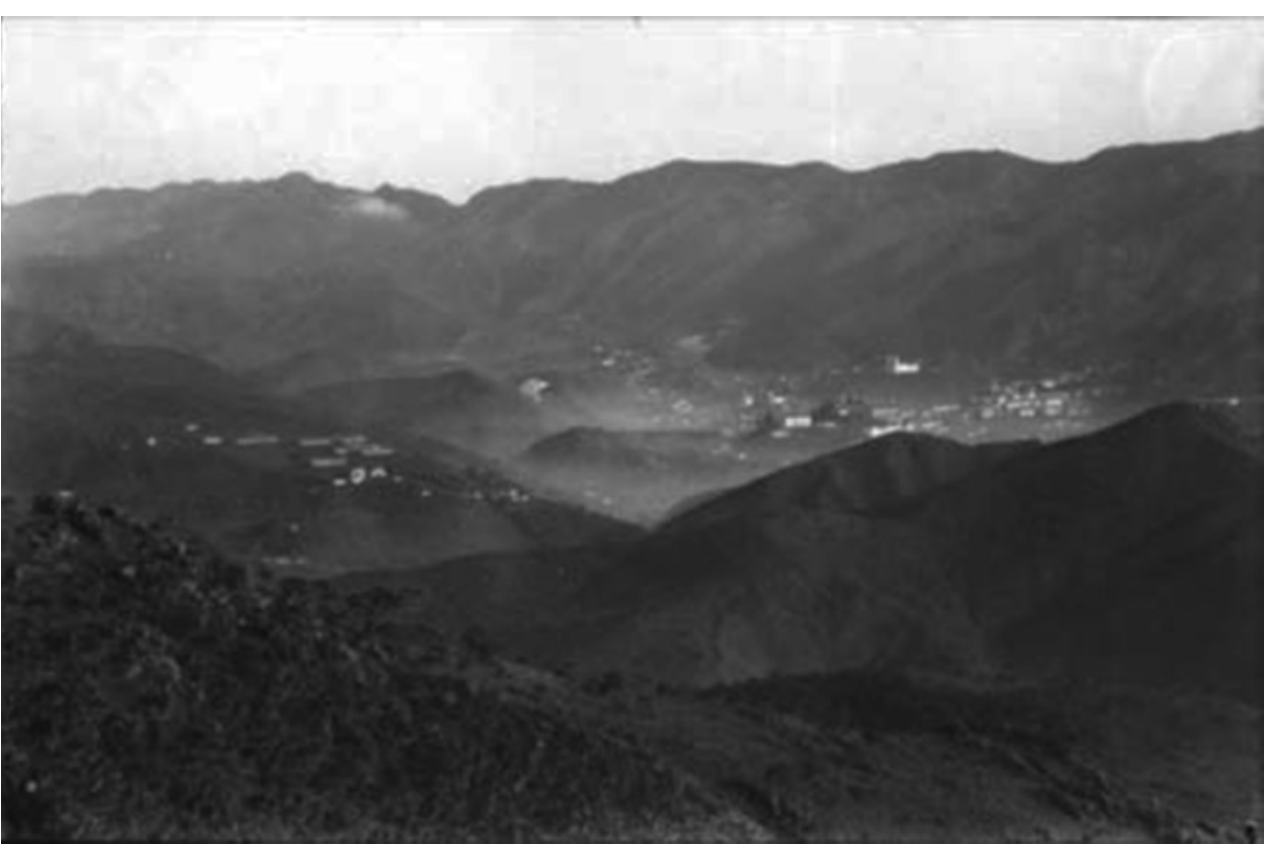



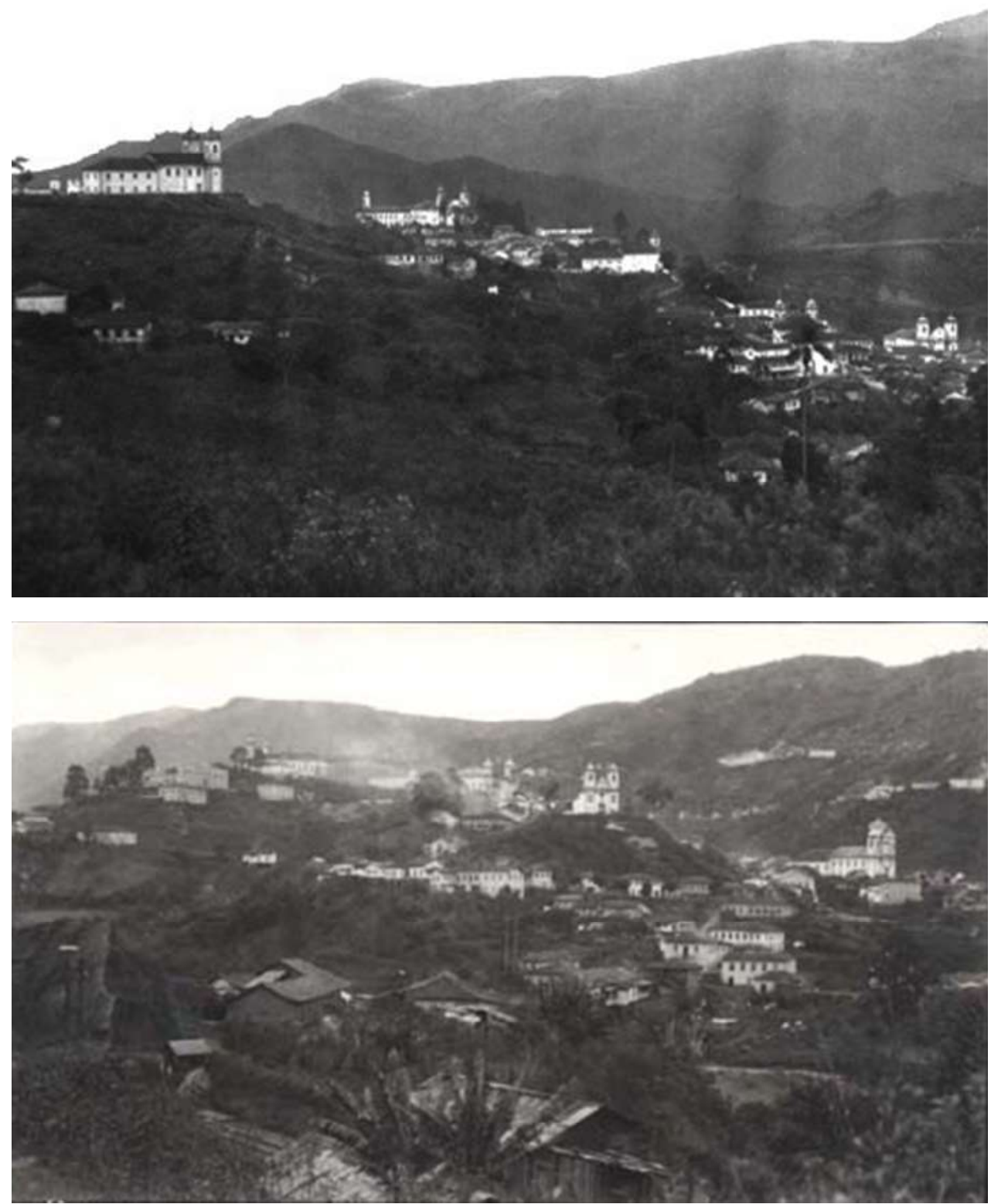

sobre a cidade, a sua verdade. Vale ressaltar o sentido da palavra verdade para o filósofo Merleau-Ponty (FP, 1945). Para ele, a verdade poderia ser chamada de "verdade relativa", não é a questão de saber se nossas evidências são verdadeiras, mas sim qual é a minha verdade sobre as coisas, esta, por sua vez, adquirida pela minha percepção. Assim, pode-se dizer que não existe a verdadeira Ouro Preto, mas sim a Ouro Preto sobre o olhar de cada um, no caso, a verdadeira Ouro Preto de Guignard e, além disso, a Ouro Preto das obras de Guignard vista sob o olhar da autora dessa pesquisa, que de fato, é uma possível interpretação, a qual envolve um diálogo entre "aquilo que a obra apresenta e aquele que a interpreta". (PONTES, 2014, p. 65)

Nesse sentido, por meio de um olhar mais atento defende-se essa hipótese de uma experiência em Ouro Preto a partir de uma análise de parâmetros encontrados nas obras do artista pela autora, levando em consideração que "a leitura deixa que a obra mesma se mostre, se apresente, para então reconstruí-la mais uma vez na interpretação". (PONTES, 2014, p. 73)
[Figura 56] Paisagem de Ouro Preto, período entre 1923 a 1950.

[Fonte] Acervo fotográfico Luiz Fontana, Instituto de Filosofia, Artes e Cultura (IFAC).

[Figura 57] Paisagem de Ouro Preto, período entre 1923 a 1950.

[Fonte] Acervo fotográfico Luiz Fontana, Instituto de Filosofia, Artes e Cultura (IFAC). 
referências 
AGUIAR, L. B. Cidade morta, cidade monumento, cidade turística: a construção de memórias sobre Ouro Preto. In: História do Turismo no Brasil. Rio de Janeiro: FGV, pp. 180-193, 2013.

Alberto da Veiga Guignard, 1896-1962. Catálogo de Exposição. Max Perlingeiro (Apresentação), Pinakotheke (Organização). Rio de Janeiro: Edições Pinakotheke, 2005.

ALVES, C. J. O desenho como suporte para os artistas viajantes no Brasil Imperial. In: V Encontro de História da Arte - 20 anos de História da Arte na UNICAMP - 2009, 2009, Campinas. V Encontro de História da Arte - 20 anos de História da Arte na UNICAMP, 2009.

ALVES, F. C. Indivisibilidades entre natureza, homem e expressão artística: a reflexão estética de Merleau-Ponty. Dissertação de mestrado Universidade Estadual Paulista Júlio de Mesquita Filho, São Paulo, 2013.

ALVES, T. Paisagem: em busca do lugar perdido. Finisterra: Revista Portuguesa de Geografia, v. XXXVI, n. 72, pp. 67-74, 2001.

AMBRIZZI, M. L. O olhar distante e o próximo - a produção dos artistasviajantes. Rio de Janeiro, v. VI, n. 1, jan./mar. 2011. Disponível em: http:// www.dezenovevinte.net/artistas/viajantes_mla2.hlm

ANDRADE, B. O. Da natureza viva à pintura bruta. Viso: Cadernos de Estética Aplicada, v. 6, pp. 1-13, 2013.

ANDRADE, M. Do Desenho. In: O Desenho de Lasar Segall. São Paulo, Museu Lasar Segall, 1991.

ANDRÉS, M. H. Guignard, o mestre. Estudos Avançados: USP. v. 10, n. 28 , pp. 319-330, 1996.

ANDRIOLO, A. Ouro Preto, 1897-1973; a construção social de uma cidade histórica turística. Dissertação de Mestrado, FAU-USP, São Paulo, 1999.

Actividad pictórica y imagen percibida: la ciudad histórico-turística de Ouro Preto. Estudios y Perspectivas en Turismo. Buenos Aires, v. 17, n. 1-2, pp. 170-184, enero/abril 2008.

. Entre a ruina e a obra de arte: psicossociologia da percepção da cidade histórica turística. Estudos de Psicologia: UFRN, v. 14, pp. 159-166, 2009.

A pintura é um traço de nossa relação histórica com o mundo. Poiesis: Niterói, v. 17, pp. 77-90, 2011.

Metamorfoses do olhar na viagem de Goethe à Itália. ArtCultura: UFU, v. 13, n. 23, pp. 113-127, jul./dez. 2011.

A paisagem da cidade histórica e turística: fenomenologia da experiência estética. Caderno Virtual de Turismo. Rio de Janeiro, v. 16, n. 3, pp. 91-105, dez. 2016.

AULICINO, M. R. O "nacionalismo lírico" de Guignard. In: $17^{\circ}$ Encontro Nacional da Associação Nacional de Pesquisadores em Artes Plásticas Panorama da Pesquisa em Artes Visuais, Florianópolis, pp. 458-467, ago. 2008.

BANDEIRA, M. Guia de Ouro Preto. Rio de Janeiro: Ministério da Educação e Saúde, 3a ed, 1957.

Ouro Preto remoçada. In: Andorinha, Andorinha. $2^{\mathrm{a}}$ ed. 
BARTALINI, V. Natureza, paisagem e cidade. Revista do Programa de PósGraduação em Arquitetura e Urbanismo (FAUUSP), v. 20, pp. 36-48, 2013.

BATISTA, M. R.; LIMA, A. P. de C. (Org.). Escritos sobre arte e modernismo brasileiro. São Paulo: Prata Design, 2012.

BELLUZZO, A. M. O Brasil dos viajantes. 2. Ed. Rio de Janeiro: Objetiva/ Metalivros, 1999.

41-57, 2008.

O viajante e a paisagem brasileira. Porto Arte: UFRGS, v. 25, pp.

BOCCHI, J. C. ; FURLAN, R. O corpo como expressão e linguagem em Merleau-Ponty. Estudos de Psicologia: Natal, v. 8, n.3, pp. 445-450, 2003.

BOSI, A. Fenomenologia do olhar. In: Adauto Novaes. (Org.). O olhar. São Paulo: Companhia das Letras, 1988, pp. 65-87.

BRITO, R. Só olhar. In: ZÍLIO, C. (Coord.). A modernidade em Guignard. Rio de Janeiro: PUC/RJ Empresas Petróleo Ipiranga, 1983, pp. 10-13.

O moderno e o contemporâneo: o novo e o outro novo. In:

Experiência crítica - textos selecionados: Ronaldo Brito. Organização de Sueli de Lima. São Paulo: Cosac \& Naify, 2005, pp. 74-88.

CAMARGO, I. Guignard. In: Guignard, uma seleção da obra do artista. São Paulo: Museu Lasar Segall/ Centro Cultural São Paulo, 1992, p. 21.

CARBONE, M. O filósofo e o cineasta: Merleau-Ponty e o pensamento do cinema. Revista da Faculdade de Biblioteconomia e Comunicação da UFRGS, v. 19, n. 2, jul/dez. 2013

CARDOSO, S. O Olhar Viajante. In: NOVAES, Adauto (Org). O olhar. São Paulo: Companhia da Letras, 1993.

CHAUI, M. S. Janela da alma, espelho do mundo. In: NOVAES, A. (Org.). O olhar. São Paulo: Companhia das Letras, 1988, pp. 31-63.

CHIARELLI, D. T. De Anita à Academia: Para repensar a História da Arte no Brasil. Novos Estudos CEBRAP (Impresso), v. 88, pp. 113-134, 2010.

COELHO, M. C. Artistas viajantes e acadêmicos. Esboços: UFSC, Florianópolis, v. 12, pp. 165-171, 2004.

COSTA, T. Pitoresco, um pensamento de arte. Domínios da Imagem, Londrina, v. 9, n. 17, pp. 218-236, jan./jun. 2015.

COSTA LIMA, L. Destinos da subjetividade: história e natureza no romantismo. In: O controle do imaginário: razão e imaginação nos tempos modernos. 2 ed. São Paulo: Rio de Janeiro: Forense Universitária, 1989, pp. 72-112.

DIENER, P.; COSTA, M. F. A América de Rugendas: obras e documentos. São Paulo: Estação Liberdade: Kosmos, 1999.

DIENER, P. A viagem pitoresca como categoria estética e a prática de viajantes. Revista Porto Arte, Porto Alegre, v. 15, n. 25, pp. 59-73, 2008. . Juan Mauricio Rugendas - Pintor y Dibujante. São Paulo: Hamburg Gráfica, 1998.

Rugendas e o Brasil. São Paulo: Capivara, 2002.

Lo pintoresco como categoria estética en el arte de viajeros. Apuntes para la obra de Rugendas. História, n. 40, vol. 2, pp. 285-309, jul/ dec 2007 
ESCOUBAS, E. Investigações fenomenológicas sobre a pintura. KRITERION. Belo Horizonte, n. 112, pp. 163-173, dez. 2005.

FIGUEIREDO, R. J. P. Do lugar vivido ao lugar imaginado: o desenho e a arquitetura. Dissertação de Mestrado em Arquitetura - Universidade Católica Portuguesa. Viseu-PT, 2015.

FONSECA, R. P. P. A arte no mercado - seus discursos como utopia. E-topia: Revista Electrónica de Estudos sobre a Utopia, n. 6, 2007.

FRANCO, M. A. Ouro Preto dos poetas modernistas. Remate de Males. Campinas, v. 33, n. 1-2, pp. 211-224, jan/dez. 2013.

FROTA, L. C. Guignard: arte, vida. Rio de Janeiro: Campos Gerais, 1997.

FURLAN, A. S. R.; FURLAN, R. Arte, linguagem e expressão na filosofia de Merleau-Ponty. ARS: USP, v. 5, pp. 30-49, 2005.

FURLAN, R.; ROZESTRATEN, A. S. Arte em Merleau-Ponty. Natureza Humana. São Paulo, v. 7, n. 1, pp. 59-93, 2005.

GIMMLER NETTO, M. M. A paisagem de Ouro Preto. Dissertação de mestrado - Escola de Arquitetura da Universidade Federal de Minas Gerais, Belo Horizonte, 2014.

HORTA, O. M. M. Mario de Andrade e os modernistas em Minas Gerais no reconhecimento da tradição para a identidade nacional. Miguilim: Revista Eletrônica do Netlli, v. 3, n. 2, pp. 113-124, mai/ago. 2014.

KLABIN, V. M. Guignard e a modernidade em Minas. In: ZÍLIO, C. (Coord.). A modernidade em Guignard. Rio de Janeiro: PUC/RJ Empresas Petróleo Ipiranga, 1983, pp. 41-49.

LEFEVRE, R.; VASCONCELLOS, S. Minas: Cidades barrocas. São Paulo: Universidade de São Paulo, 1968.

LIMANETO, J. M. Pintura e corpo na filosofia de Merleau-Ponty. Dissertação de mestrado - Universidade Federal da Paraíba, Paraíba, 2011.

LIMA, J. T. P. Maurice Merleau-Ponty, Paul Cézanne e o problema da essência da pintura. Revista Filosófica de Coimbra, v. 7, n. 13, 1998.

MARTí, S. Guignard e o oriente: China, Japão e Minas. Catálogo de exposição. Paulo Herkenhoff e Priscila Freire (Curadoria). São Paulo: Instituto Tomie Ohtake, 2010.

MARCON, G. H.; FURLAN, R. Afeto e subjetividade nos primeiros trabalhos de Merleau-Ponty. Memorandum. Belo Horizonte, v. 29, pp. 208-232, 2015.

MERLEAU-PONTY, M. A dúvida de Cézanne. In: O olho e o espírito. Tradução de Cassio de Arantes Leite. São Paulo: Cosac \& Naify, 2004, pp. 121-142.

MERLEAU-PONTY, M. A linguagem indireta e as vozes do silêncio. In: . O olho e o espírito. Tradução de Cassio de Arantes Leite. São Paulo: Cosac \& Naify, 2004, pp. 65-120.

MERLEAU-PONTY, M. O olho e o espírito. In: O olho e o espírito. Tradução de Cassio de Arantes Leite. São Paulo: Cosac \& Naify, 2004, pp. 13-46.

MIGUES, F. A dissolução em Guignard. Revista Novos Estudos. São Paulo, n. 83, pp. 205-209, mar. 2009.

MORAIS, F. Guignard. São Paulo: Centro de Artes Novo Mundo, 1974. 
MORAIS, F. O humanismo lírico de Guignard. In. MUSEU NACIONAL DE BELAS ARTES. O Humanismo Lírico de Guignard. Rio de Janeiro: Associação dos Amigos do Museu Nacional de Belas Artes, 2000, pp. 15-33.

MOTTA, L. A SPHAN em Ouro Preto: uma história de conceitos e critérios. Revista do Patrimônio Histórico e Artístico Nacional, n. 22, pp. 108-122, 1987.

MULLER, M. L. A questão do suporte na obra de Guignard. In: ZÍLIO, C. (Coord.). A modernidade em Guignard. Rio de Janeiro: PUC/RJ Empresas Petróleo Ipiranga, 1983, pp. 22-26.

MUSEU LASAR SEGALL. Guignard: Uma seleção da obra do artista. Catálogo de exposição. São Paulo: Secretaria Municipal de Cultura, 1992.

NATAL, C. M. Ouro Preto: a construção de uma cidade histórica, 18911933. Dissertação de mestrado - Departamento de História do Instituto de Filosofia e Ciências Humanas da Universidade Estadual de Campinas, Campinas, 2007.

. Imagens de Ouro Preto: a construção de uma cidade histórica, 1891-1933. In: XXIII Simpósio Nacional de História. História: Guerra e Paz, 2005, Londrina- PR. Anais do XXIII Simpósio Nacional de História. História: Guerra e Paz, 2005.

NAVES, R. A maldade de Guignard. In: MUSEU LASAR SEGALL. Guignard: Uma seleção da obra do artista. São Paulo: Secretaria Municipal de Cultura/ Prefeitura do Município de São Paulo, 1992, pp. 11 - 14.

. O Brasil no ar: Guignard. In:

. A Forma Difícil: ensaios sobre arte brasileira. São Paulo: Editora Ática, 1996, pp. 131-143.

NÓBREGA, T. P. Corpo, percepção e conhecimento em Merleau-Ponty. Estudos de Psicologia. Natal, v. 13, pp. 141-148, 2008.

OLIVEIRA, M. R. S. O fenômeno turístico e suas implicações na cidade de Ouro Preto. In: II ANPPAS - Encontro da Associação Nacional de Pesquisa e Pós-Graduação em Ambiente e Sociedade, Indaiatuba, 2004. Anais do II Encontro da Associação Nacional de Pós-Graduação e Pesquisa em Ambiente e Sociedade ANPPAS, 2004.

PALHARES, T. H. P. Modernidade, tradição e caráter nacional na obra de Alberto da Veiga Guignard. Tese de doutorado, FFLCH-USP, São Paulo, 2010.

PALLAMIN, V. M. Fenomenologia, paisagem e arte contemporânea. Paralaxe - Revista de Estética e Filosofia da Arte, v. 4, pp. 43-61, 2015

PALLASMAA, J. As mãos inteligentes: a sabedoria existencial e corporalizada na arquitetura. Tradução de Alexandre Salvaterra. Porto Alegre: Bookman, 2013.

PEREIRA, S. G. Revisão historiográfica da arte brasileira do século XIX. Revista IEB, v. 54, pp. 87-106, 2012.

PIMENTEL, T. V. C. Viajar e narrar: toda viagem destina-se a ultrapassar fronteiras. Varia História: UFMG (Impresso). Belo Horizonte, v. 26, n.25, pp. 81-120, 2001.

PONTES, C. M. A experiência hermenêutica da arte em Gadamer. Peri: UFSC. Florianópolis, v. 06, n. 01, pp. 63-76, 2014.

148 RAMOS, T. A. M. S. Corpos do afeto: ensaio sobre a dança, estesiologia e 
educação. Tese de doutorado em Educação - Universidade do Rio Grande do Norte, Natal, 2017.

REIS FILHO, N. G. Quadro da arquitetura no Brasil. São Paulo: Perspectiva, 1970.

REIS, N. G. Imagens de vilas e cidades do Brasil Colonial [Colaboradores: Paulo Bruna e Beatriz P. Siqueira Bueno]. São Paulo: EDUSP-FAPESP, 2000.

ROGER, A. La naissance du paisage en Occident. In: SALGUEIRO, H. A. (Org.). Paisagem e arte: a invenção da natureza, a evolução do olhar. São Paulo: CBHA / CNPq / Fapesp, pp. 33-39, 2000.

SALGADO, M. Ouro Preto: paisagem em transformação. Dissertação de mestrado - Escola de Arquitetura da Universidade Federal de Minas Gerais, Belo Horizonte, 2010.

SALGUEIRO, H. A. Ouro Preto: dos gestos de transformação do "colonial" aos de construção de um "antigo moderno". Anais do Museu Paulista, São Paulo, v.4, pp. 125-63, jan/dez. 1996.

SALZSTEIN, S. Um ponto de vista singular. In: Guignard, uma seleção da obra do artista. São Paulo: Museu Lasar Segall/ Centro Cultural São Paulo, 1992, pp. 15-19.

SANDEVILLE JR., E. As Sombras da Floresta: vegetação, paisagem e cultura no Brasil. Tese de Doutorado - Faculdade de Arquitetura, USP, São Paulo, 1999.

. Johann Moritz Rugendas: vivência, observação e invenção de uma natureza tropical brasileira. In: Paisagens Culturais. Interfaces entre Tempo e Espaço na Construção da Paisagem Sul-Americana. Ed. Rio de Janeiro: Escola Nacional de Belas Artes publicações, 2008, v.2, pp. 199-210.

2012.

. Paisagens partilhadas. Paisagem e Ambiente, v. 30, pp. 205-214,

SANTOS, P. Passos de Guignard em Ouro Preto (entrevista). Projeto Guignard. 2003. Disponível em: http://www1.cultura.mg.gov.br/fronteira/ template/entrevista/pierre_santos.pdf

SCHENK, L. B. M. Arquitetura da Paisagem: entre o Pinturesco, Olmsted e o Moderno. Tese de Doutorado - Escola de Engenharia de São Carlos, USP, São Carlos, 2008.

SCHENKER, L. As circunstâncias de um ato criador: entre o real e a fantasia. In: ZÍLIO, C. (Coord.). A modernidade em Guignard. Rio de Janeiro: PUC/ RJ Empresas Petróleo Ipiranga, 1983, pp. 27-36.

SCHWARCZ, L. M.; STARLING, H. Brasil: uma biografia. São Paulo: Companhia das Letras, 2015.

SILVA, V. R. F. Estariam Ouro Preto e Mariana preservadas? remanescências das formas de viver e construir. XI Encontro Nacional da Associação Nacional de Pós-Graduação e Pesquisa em Planejamento Urbano e Regional - ANPUR, Salvador, mai. 2005.

SODRÉ, J. C. A. Arquitetura e viagens de formação pelo Brasil 1938-1962. Dissertação de mestrado - FAU-USP, São Paulo, 2010.

SÜSSEKIND, F. A ciência da viagem. In: O Brasil não é longe daqui: o narrador, a viagem. São Paulo: Cia. das Letras, 1990. 
TELÉSFORO, G. B.; LOURENÇO, C. A paisagem entre a ciência e a arte: a influência do olhar humboldtiano na obra de Johann Moritz Rugendas. In: XVI Encontro Nacional de Geógrafos, 2010, Porto Alegre. Anais do XVI Encontro Nacional de Geógrafos. Porto Alegre: AGB, 2010.

Um mundo a perder de vista: Guignard. Porto Alegre: Fundação Iberê Camargo, 2008. 76 p. il. Catálogo de Exposição. Curadoria de José Augusto Ribeiro.

VASCONCELLOS, S. Vila Rica. São Paulo: Perspectivas, 1977.

VEIGA, R. M. Sociedade de consumo, mercado de arte e indústria cultural. Alceu, v. 6, n. 11, pp. 153-184, jul./dez. 2005.

VIEIRA, I. L. A Escola Guignard na cultura modernista de Minas 1944 1962. Pedro Leopoldo, MG: Companhia Empreendimento Sabará, 1988.

VIEIRA, L. C. O colonial como marca: aspectos da evolução urbana de Ouro Preto. Tese de doutorado - Faculdade de Arquitetura e Urbanismo da Universidade de São Paulo, São Paulo, 2016.

VITTE, A.; CENE, V. R. Johann Moritz Rugendas: entre a pintura de paisagem e a construção das tipologias tropicais. Boletim Gaúcho de Geografia, v. 38, pp. 73-90, 2012.

ZENHA, C. O Brasil de Rugendas nas edições populares ilustradas. Topoi, Rio de Janeiro, pp. 134-160, dez. 2002.

ZíLIO, C. Com a cabeça nas nuvens. In: (Coord.). A modernidade em Guignard. Rio de Janeiro: PUC/RJ Empresas Petróleo Ipiranga, 1983, pp. 18-21. 


\section{apêndices}

Apêndice 1: Linha do tempo das obras de Guignard, 2017. 


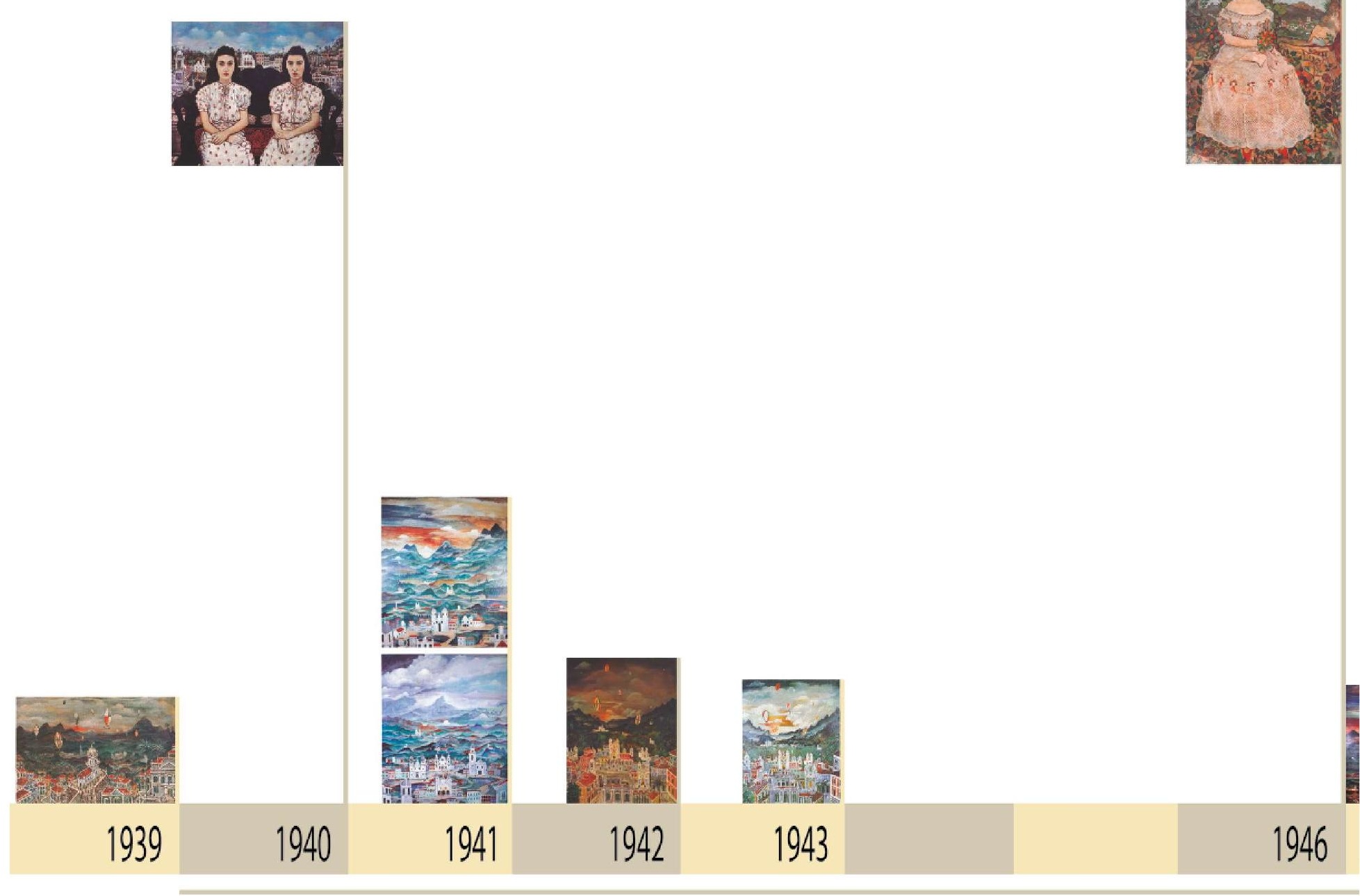

* As obras localizadas na parte inferior são obras não datadas ou, então, apenas datadas quanto às décadas. A posição delas foi uma escolha da pesqu 


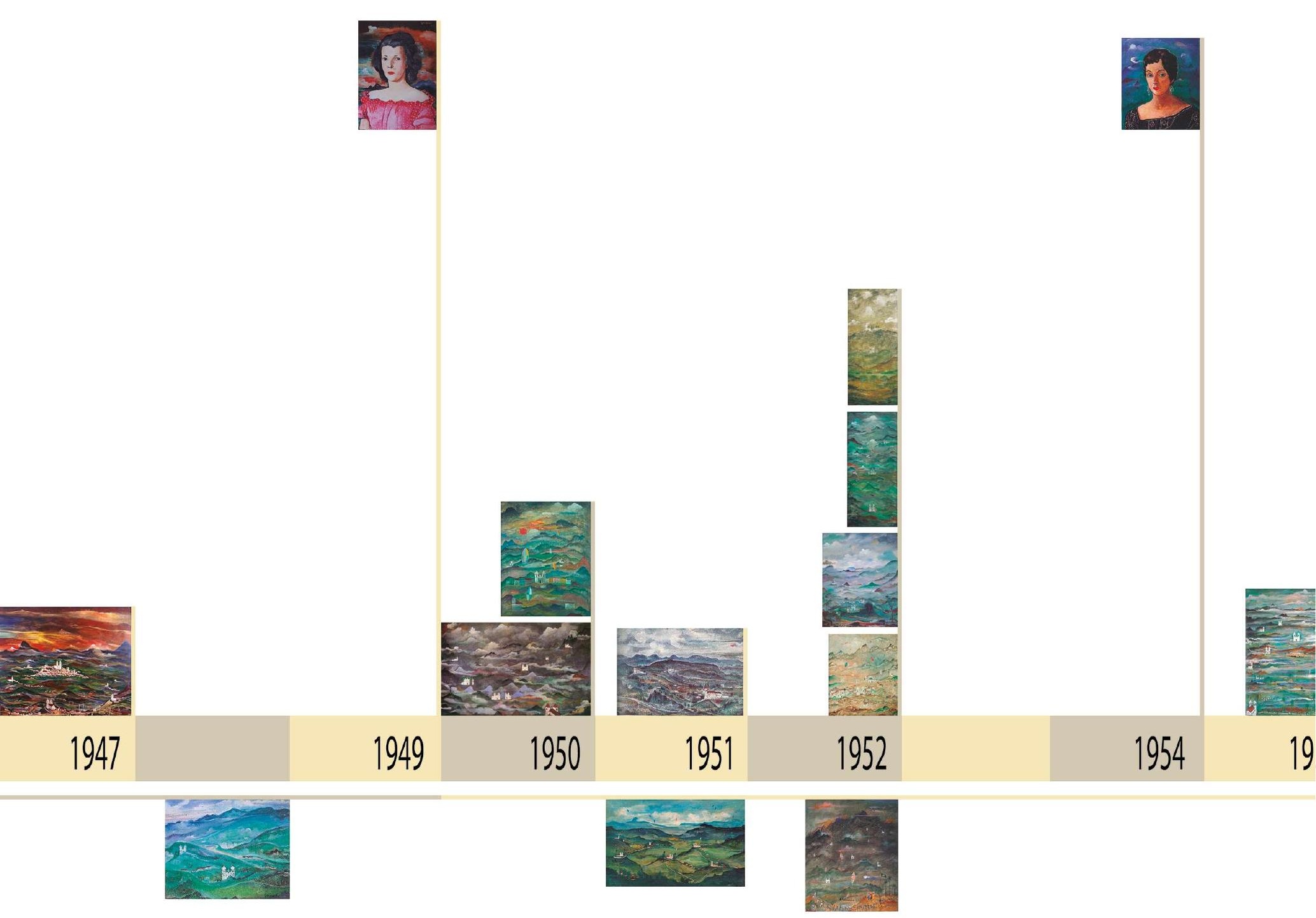



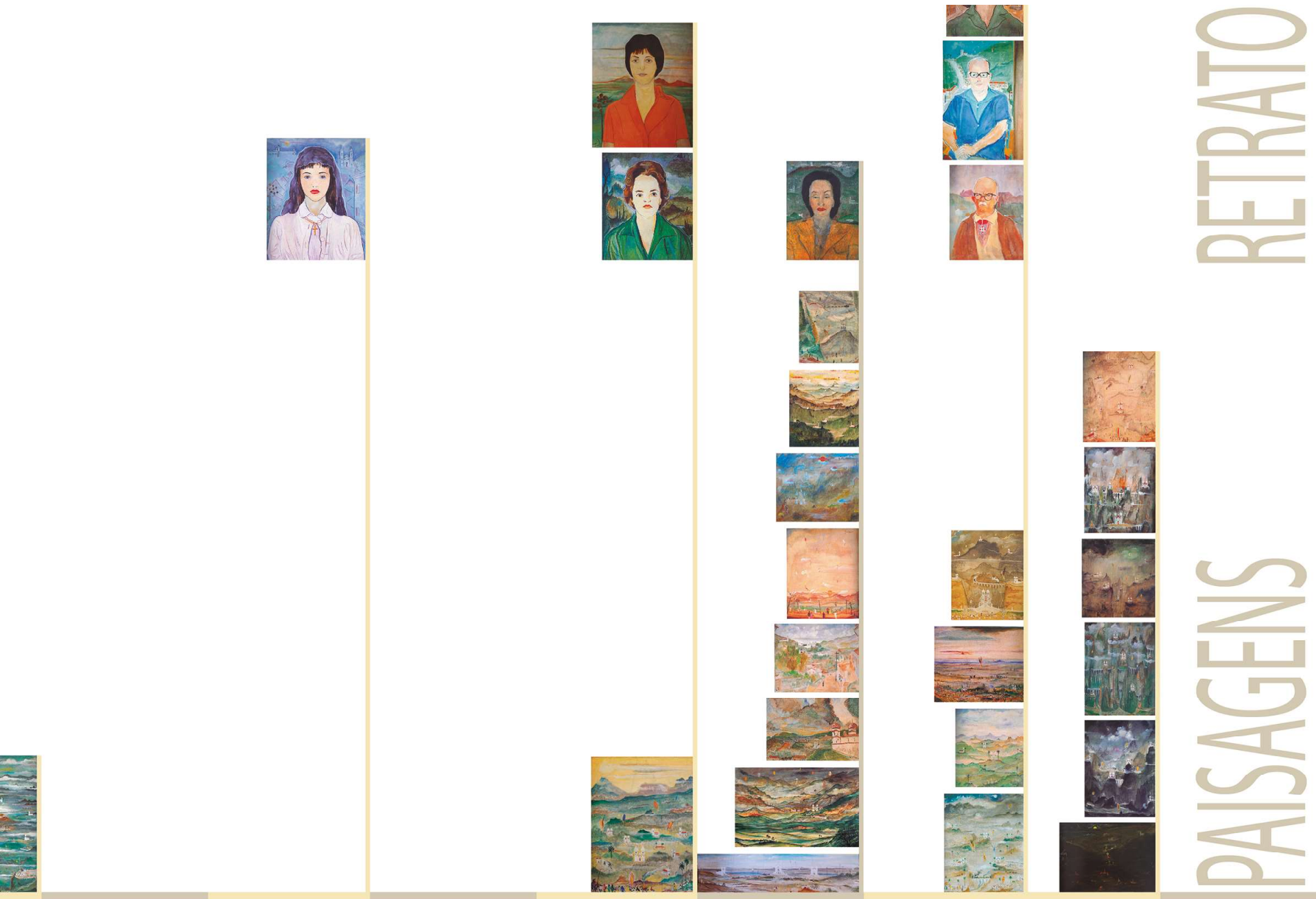

1957

1959

1960
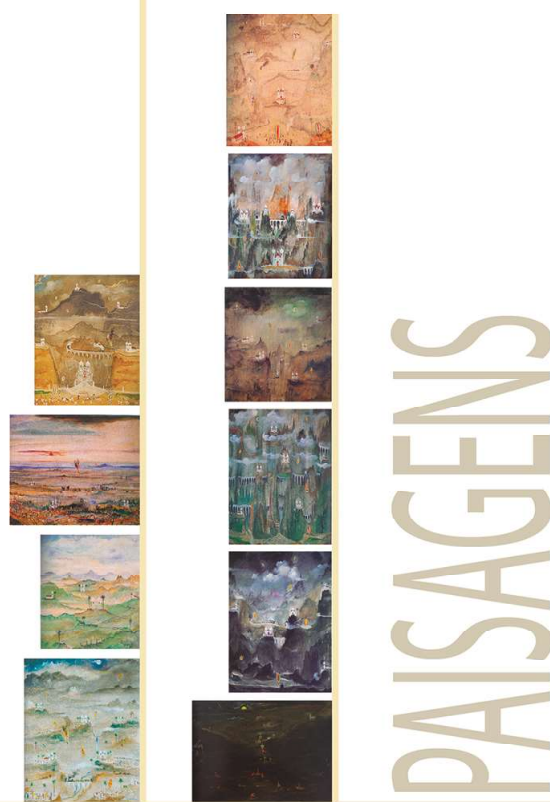

1961

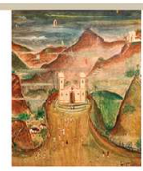


Referências e representação de escala das obras de Guignard presentes na linha do tempo [Apêndice 1]

\section{Retratos:}

1. As gemeas Lea e Maura, 1940, 110 x 130cm. Fonte: FROTA, 1997.

2. Marília de Dirceu, 1946, 172 x 116cm. Fonte: FROTA, 1997.

3. Retrato de Maria Urbana Pentagna Guimarães, 1949, $55 \times 44 \mathrm{~cm}$. Fonte: Alberto da Veiga Guignard, 1896-1962, 2005.

4. Retrato de Sara Ávila, 1954, 50 x 41cm. Fonte: FROTA, 1997.

5. Marília de Dirceu, 1957, 61,5 x 51,5 cm. Fonte: FROTA, 1997.

6. Retrato de Maria do Carmo Neves do Valle Simões, 1959, 63 x 51cm. Fonte: Alberto da Veiga Guignard, 1896-1962, 2005.

7. Retrato de Priscila Freire, 1959, 55 x 46cm. Fonte: FROTA, 1997.

8. Retrato de Lúcia, 1960, 48,2 x 35,5cm. Fonte: FROTA, 1997.

9. Retrato, 1961, $50 \times 40 \mathrm{~cm}$. Fonte: FROTA, 1997.

10. Retrato de Wilson Frade, $1961,79 \times 58,5 \mathrm{~cm}$. Fonte: FROTA, 1997.

11. Autorretrato, 1961, 64,5 x 50cm. Fonte: FROTA, 1997. 


\section{Paisagens:}

1. Paisagem Imaginante, 1939, 55 x 80cm. Fonte: FROTA, 1997.

2. Paisagem Imaginante, 1941, $150 \times 100 \mathrm{~cm}$. Fonte: FROTA, 1997.

3. Paisagem Imaginante, 1941, $150 \times 100 \mathrm{~cm}$. Fonte: FROTA, 1997.

4. Paisagem Imaginante, 1942, 80 x 60cm. Fonte: FROTA, 1997.

5. Paisagem Imaginante, 1943, 41 x 33cm. Fonte: FROTA, 1997.

6. Paisagem, 1947, $158 \times 208 \mathrm{~cm}$. Fonte: FROTA, 1997.

7. Paisagem de Minas, década de 1940, 32 x 40cm. Fonte: Alberto da Veiga Guignard, 1896-1962, 2005.

8. Noite de São João, $1950,76,5$ x 60cm. Um mundo a perder de vista: Guignard, 2008.

9. Paisagem Imaginante, 1950, $80 \times 110 \mathrm{~cm}$. Fonte: FROTA, 1997.

10. Paisagem de Ouro Preto, $1951,29 \times 42 \mathrm{~cm}$. Fonte: MUSEU LASAR SEGALL, 1992.

11. Balõezinhos, sem data, $29,5 \times 47 \mathrm{~cm}$. Fonte: Um mundo a perder de vista: Guignard, 2008.

12. Paisagem Imaginária, 1952, $160 \times$ 70,5cm. Fonte: FROTA, 1997.

13. Paisagem, 1952, $160 \times 79 \mathrm{~cm}$. Fonte: Um mundo a perder de vista: Guignard, 2008.

14. Paisagem Imaginante, 1952, 100x80cm. Fonte: FROTA, 1997.

15. Noite de São João, 1952, 55 x 44cm. Fonte: Um mundo a perder de vista: Guignard, 2008.

16. Paisagem Imaginante, década de 1950, 61 x 50cm. Fonte: FROTA, 1997.

17. Paisagem Imaginante, 1955, 95 x 78cm. Fonte: FROTA, 1997.

18. São João, 1959, $38.5 \times 29 \mathrm{~cm}$. Fonte: FROTA, 1997.

19. Paisagem Imaginante, $1960,50 \times 46 \mathrm{~cm}$. Fonte: http://pintoresdobrasil.blogspot. com/. Acesso em: 07/11/2018.

20. Paisagem Onírica de Ouro Preto, 1960. Fonte: http://pintoresdobrasil.blogspot. com/. Acesso em: 07/11/2018.

21. Procissão Semana Santa, 1960,46 x 55cm. Fonte: Alberto da Veiga Guignard, 1896-1962, 2005.

22. Paisagem Imaginante, 1960, 50 x 40cm. Fonte: FROTA, 1997.

23. Ouro Preto, 1960, $45.5 \times 54.5 \mathrm{~cm}$. Fonte: FROTA, 1997.

24. Ouro Preto, 1960, 36 x 54cm. Fonte: FROTA, 1997. 


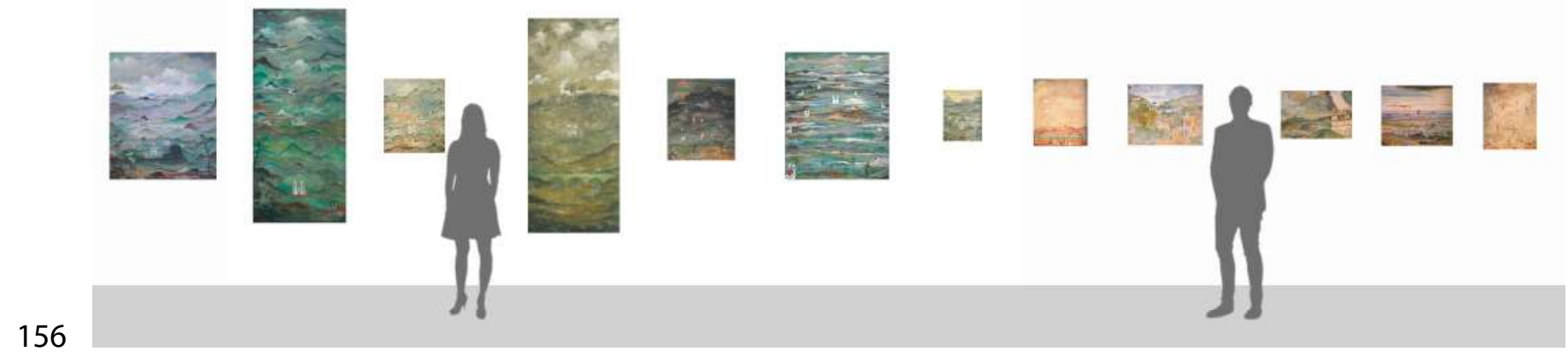


25. Ouro Preto, 1960. Fonte: https://vejasp.abril.com.br/atracao/arte-no-brasil-umahistoria-do-modernismo-na-pinacoteca-de-sao-paulo/. Acesso em: 07/11/2018.

26. Fantasia, 1960, 28 x 120cm. Fonte: Alberto da Veiga Guignard, 1896-1962, 2005.

27. Paisagem Imaginante, sd. http://www.santaterezatem.com.br/index.php/event/ guignard-e-paisagem-mineira-o-antes-e-o-depois-em-exposicao/. Acesso em: 07/11/2018.

28. São João, 1961, 55 x 46cm. Fonte: Alberto da Veiga Guignard, 1896-1962, 2005.

29. Paisagem, 1961, 45 x 53,5cm. Fonte: FROTA, 1997.

30. Paisagem Imaginante, 1961, 50 x 43cm. Fonte: FROTA, 1997.

31. São João, 1961, 61 x 46cm. Fonte: Alberto da Veiga Guignard, 1896-1962, 2005.

32. Balões, sd, 36 x 27,7cm. Fonte: MUSEU LASAR SEGALL, 1992.

33. Sem título [festa junina], $1961,50 \times 40 \mathrm{~cm}$. Fonte: MUSEU LASAR SEGALL, 1992.

34. Paisagem Imaginante, 1961, 55 x 46cm. Fonte: FROTA, 1997.

35. Paisagem Imaginante, 1961, 55 x 46cm. Fonte: FROTA, 1997.

36. Paisagem Imaginante, 1961, 61 x 46cm. Fonte: FROTA, 1997.

37. Paisagem Imaginante, 1961, 61 x 46cm. Fonte: FROTA, 1997.

38. Procissão Semana Santa Noturna, $1961,32,5$ x 46cm. Fonte: Alberto da Veiga Guignard, 1896-1962, 2005. 
Fevereiro

2019 
